VILNIAUS GEDIMINO TECHNIKOS UNIVERSITETAS

Povilas ZDANEVIČIUS

\title{
ŠAMOTINIO UGNIAI ATSPARAUS BETONO ŠARMINIO ATSPARUMO TYRIMAI
}

DAKTARO DISERTACIJA

TECHNOLOGIJOS MOKSLAI, MEDŽIAGỤ INŽINERIJA (T 008)

Vilnius, 2021 
Disertacija rengta 2016-2021 metais Vilniaus Gedimino technikos universitete.

\section{Vadovas}

dr. Valentin ANTONOVIČ (Vilniaus Gedimino technikos universitetas, medžiagų inžinerija - T 008).

Vilniaus Gedimino technikos universiteto Medžiagų inžinerijos mokslo krypties disertacijos gynimo taryba:

\section{Pirmininkas}

dr. Viktor GRIBNIAK (Vilniaus Gedimino technikos universitetas, medžiagų inžinerija - T 008).

\section{Nariai:}

prof. dr. Darius BAČINSKAS (Vilniaus Gedimino technikos universitetas, statybos inžinerija - T 002),

dr. Jūratė ČĖSNIENĖ (Lietuvos energetikos institutas, medžiagų inžinerija T 008),

dr. Olga KIZINIEVIČ (Vilniaus Gedimino technikos universitetas, medžiagų inžinerija - T 008),

habil. dr. Jacek PODWORNY (Lukasiewicz tyrimu tinklo keramikos ir statybinių medžiagų institutas, Lenkija, medžiagų inžinerija - T 008).

Disertacija bus ginama viešame Medžiagų inžinerijos mokslo krypties disertacijos gynimo tarybos posėdyje 2021 m. birželio 8 d. 10 val. Vilniaus Gedimino technikos universiteto senato posèdžių salëje.

Adresas: Saulètekio al. 11, LT-10223 Vilnius, Lietuva.

Tel.: (8 5) 274 4956; faksas (8 5) 270 0112; el. paštas doktor@vilniustech.lt

Pranešimai apie numatomą ginti disertaciją išsiųsti $2021 \mathrm{~m}$. gegužès $7 \mathrm{~d}$.

Disertaciją galima peržiūrèti Vilniaus Gedimino technikos universiteto talpykloje http://dspace.vgtu.lt ir Vilniaus Gedimino technikos universiteto bibliotekoje (Saulètekio al. 14, LT-10223 Vilnius, Lietuva).

Vilniaus Gedimino technikos universiteto 2021-024-M mokslo literatūros knyga

doi: 10.20334/2021-024-M

(C) Vilniaus Gedimino technikos universitetas, 2021

(C) Povilas Zdanevičius, 2021

povilas.zdanevicius@vilniustech.lt 
VILNIUS GEDIMINAS TECHNICAL UNIVERSITY

Povilas ZDANEVIČIUS

THE INVESTIGATION OF ALKALI

RESISTANCE OF FIRECLAY REFRACTORY CASTABLE

DOCTORAL DISSERTATION

TECHNOLOGICAL SCIENCES,

MATERIALS ENGINEERING (T 008)

Vilnius, 2021 
Doctoral dissertation was prepared at Vilnius Gediminas Technical University in 2016-2021.

\section{Supervisor}

Dr Valentin ANTONOVIČ (Vilnius Gediminas Technical University, Materials Engineering - T 008).

The Dissertation Defense Council of Materials Engineering of Vilnius Gediminas Technical University:

\section{Chairman}

Dr Viktor GRIBNIAK (Vilnius Gediminas Technical University, Materials Engineering - T 008).

\section{Members:}

Prof. Dr Darius BAČINSKAS (Vilnius Gediminas Technical University, Civil Engineering - T 002),

Dr Jūratė ČĖSNIENÉ (Lithuanian Energy Institute, Materials Engineering T 008),

Dr Olga KIZINIEVIČ (Vilnius Gediminas Technical University, Materials Engineering - T 008),

Dr Habil. Jacek PODWORNY (Lukasiewicz Research Network - Institute of Ceramics and Building Materials, Materials Engineering - T 008).

The dissertation will be defended at the public meeting of the Dissertation Defence Council of Materials Engineering in the Senate Hall of Vilnius Gediminas Technical University at 10 a. m. on 8 June 2021.

Address: Saulètekio al. 11, LT-10223 Vilnius, Lithuania.

Tel.: +370 5274 4956; fax +370 5270 0112; e-mail: doktor@vilniustech.lt

A notification on the intend defending of the dissertation was send on 7 May 2021.

A copy of the doctoral dissertation is available for review at Vilnius Gediminas Technical University repository http://dspace.vgtu.lt and at the Library of Vilnius Gediminas Technical University (Sauletekio al. 14, LT-10223 Vilnius, Lithuania). 


\section{Reziumè}

Disertacijoje nagrinèjamas šamotinio ugniai atsparaus betono šarminis atsparumas aukštoje temperatūroje. Jo struktūrai modifikuoti panaudotas malto kvarcinio smèlio priedas. Disertacijos tikslas - padidinti cementinio ugniai atsparaus betono su šamoto užpildu šarmini atsparumą eksploatuojant $1100-1200{ }^{\circ} \mathrm{C}$ temperatūroje.

Disertaciją sudaro îvadas, trys skyriai, bendrosios išvados, literatūros ir autoriaus publikacijų disertacijos tema sąrašai, santrauka anglų kalba, bei keturi priedai. Ivadiniame skyriuje aptariama tiriamoji problema, darbo aktualumas, aprašomas tyrimų objektas, formuluojamas darbo tikslas bei uždaviniai, aprašoma tyrimų metodika, darbo mokslinis naujumas, darbo rezultatų praktinè reikšmė, ginamieji teiginiai. Ivado pabaigoje pristatomos disertacijos tema autoriaus paskelbtos publikacijos ir pranešimai konferencijose bei disertacijos struktūra.

Pirmajame skyriuje analizuojami šie klausimai:

- aliumosilikatinių medžiagų atsparumas šarminei korozijai;

- ugniai atsparaus betono panaudojimo kieto biokuro pakurų išklojose ypatumai;

- ugniai atsparių medžiagų šarminio atsparumo galimos pagerinimo priemonès.

Skyriaus pabaigoje formuluojamos išvados ir tikslinami disertacijos uždaviniai.

Antrajame skyriuje aprašomos darbe naudotos žaliavos ir jų savybès, pateiktos ugniai atsparių betonų sudètys ir bandinių paruošimo metodika. Pateikiami kiti taikomi tyrimo metodai, kurie parinkti siekiant išsiaiškinti kvarcinio smèlio priedo itaką ịprastinio ir vidutinio cemento kiekio ugniai atsparaus betono su šamoto užpildu šarminiam atsparumui ir destrukcijos procesui, kai veikia terminiai smūgiai.

Trečiajame skyriuje pateikiami nustatyti ịvairių rūšių šamoto šarminès korozijos proceso ypatumai. Atlikti iprastinio ir vidutinio cemento kiekio ugniai atsparių betonu su malto kvarcinio smèlio priedu eksploataciniu savybiu ir atsparumo šarminei korozijai tyrimai. Taip pat nustatyti atsparaus šarminei korozijai barjero formavimosi skirtinguose betonuose ypatumai. Pateiktas aprašymas, kaip sukurtas ugniai atsparus betonas su šamoto užpildu, kuriame $\mathrm{Al}_{2} \mathrm{O}_{3} / \mathrm{SiO}_{2}$ santykis siekia 0,89 , pasižymintis padidintu šarminiu atsparumu ir pagerintomis eksploatacinėmis savybėmis ir tinkantis kieto biokuro energetinių šilumos agregatų išklojoms.

Disertacijos medžiaga paskelbta 4 moksliniuose straipsniuose, o tyrimų rezultatai pristatyti 6 mokslinèse konferencijose Lietuvoje ir užsienyje. 


\section{Abstract}

The dissertation considers the alkali resistance of refractory fireclay (aluminosilicate) castables with modifying additives at high temperatures. The addition of ground quartz sand were used to modify its structure. The aim of the dissertation is to increase the alkali resistance of refractory castable with fireclay filler when operating at $1100-1200{ }^{\circ} \mathrm{C}$.

The dissertation consists of the introduction, three chapters, general conclusions, references and the list of the author's publications on the topic of the dissertation, summary in English and 4 appendixes. The introductory chapter discusses the research problem, the relevance of the work, describes the object of research, formulates the aim and the objectives of the work, describes the research methodology, scientific novelty of the work, the practical significance of the results, defended statements. At the end of the introduction, the list of the author's publications and conference papers on the topic of the dissertation and the structure of the dissertation are presented.

The first chapter deals with:

- the resistance of aluminosilicate materials to alkali corrosion;

- the peculiarities of the use of refractory concrete in the linings of solid fuel furnaces;

- possible measures to improve the alkali resistance of refractory materials.

At the end of the chapter, conclusions are formulated and the tasks of the dissertation are specified.

The second chapter describes the raw materials used in the work and their properties, refractory castable compositions and sample production technology, applied research methods selected to determine the effect of quartz sand admixture on the resistance of conventional and medium cement refractory concrete to alkali corrosion and destruction process under load of thermal shocks.

The third chapter identifies the peculiarities of the alkali corrosion process of different types of fireclay filler. Studies on the performance and alkali resistance of conventional and medium cement refractory castables with addition ground quartz sand have been performed. The parameters and peculiarities of alkali corrosion resistance barrier formation in different castables have been determined. The developed refractory castable with fireclay filler $\left(\mathrm{Al}_{2} \mathrm{O}_{3} / \mathrm{SiO}_{2}\right.$ ratio 0,89) has increased alkali resistance and improved performance properties suitable for the lining of solid biofuel boiler plants equipment.

The dissertation materials have been published in 4 scientific articles, and the research results have been presented at 6 scientific conferences in Lithuania and abroad. 


\section{Žymèjimai}

\section{Simboliai}

$\mathrm{S}_{\mathrm{pav}}-$ Savitasis paviršius, $\mathrm{m}^{2} / \mathrm{kg}$;

$\mathrm{T}_{0,5}$ - Betono deformacijos temperatūros pradžia;

$\mathrm{T}_{5}-$ Betono $5 \%$ deformacijos temperatūra;

$\mathrm{V}_{\mathrm{UI}}$ - Ultragarso impulso sklidimo greitis, $\mathrm{m} / \mathrm{s}$;

$\Delta \mathrm{UV}$ - Ultragarso impulso sklidimo greičio pokytis, $\mathrm{m} / \mathrm{s}$.

\section{Santrumpos}

A - Anortitas (Triklininè);

$\mathrm{A}^{\circ}$ - Anatazas (Tetragoninè);

AC40 - „Istra 40“ markès kalcio aliuminatinis cementas;

AC70 - „Gorkal 70“ markès kalcio aliuminatinis cementas;

$\mathrm{B} 2, \mathrm{~B} 3, \mathrm{~B} 4$ - Iprastinio betono modifikuoto $\mathrm{SiO}_{2}$ mikrodulkiu ir deflokulianto priedais žymuo;

$\mathrm{BQ} 2, \mathrm{BQ} 3, \mathrm{BQ} 4$ - Iprastinis betonas modifikuotas $\mathrm{SiO}_{2}$ mikrodulkemis, deflokuliantu ir kvarciniu smèliu;

$\mathrm{C}$ - Kristobalitas (Tetragoninè);

$\mathrm{C}_{\mathrm{a}}-\mathrm{CA}$ (Monoklininè);

$\mathrm{C}_{\mathrm{o}}$ - Korundas (Trigoninè);

EDS - Energijos dispersijos spektroskopija;

$\mathrm{G}$ - Gelenitas (Tetragoninè);

$\mathrm{G}_{\mathrm{r}}-$ Grositas (Monoklinine);

$\mathrm{K}$ - Kalsilitas (Heksagoninè);

$\mathrm{L}_{1}$ - Leucitas (Kubinè);

$\mathrm{L}_{2}$ - Leucitas (Tetragoninè); 
M - Mulitas (Ortorombinè);

$\mathrm{M}_{\mathrm{a}}$ - Maghemitas (Tetragoninè);

MCB - Mažo cemento kiekio betonas;

MKS - Maltas kvarcinis smèlis;

Q - Kvarcas (Trigoninè);

SEM - Skenuojančioji elektroninė mikroskopija;

$\mathrm{T}$ - Tridimitas (Ortorombinè);

VCB2, VCB3, VCB4 - Vidutinio cemento kiekio betonas modifikuotas kvarciniu smèliu;

VCB3-F, VCB4-F - Betonas su metalinès fibros priedu;

$\mathrm{W}_{1}$ - Vadeitas (Heksagoninè);

$\mathrm{W}_{2}$ - Kalio silikatas „Vadelitas“ (Heksagoninè);

XRD - Rentgeno spindulių difrakcija. 


\section{Turinys}

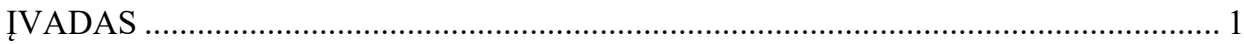

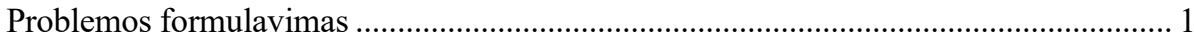

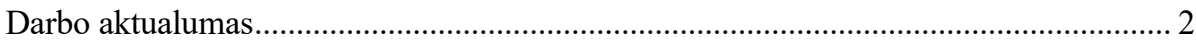

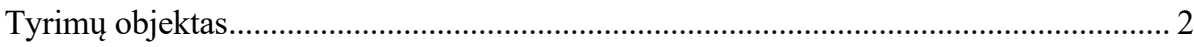

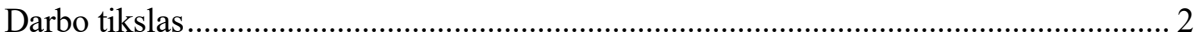

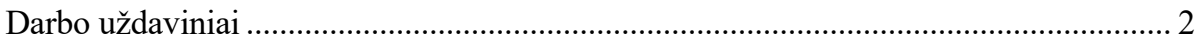

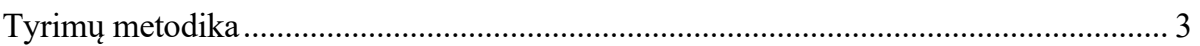

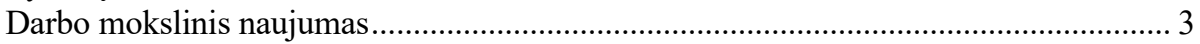

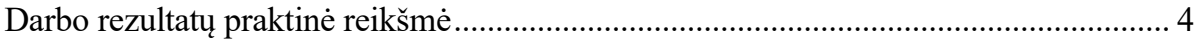

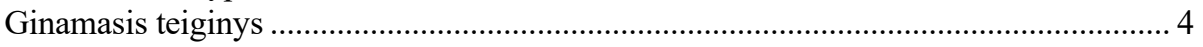

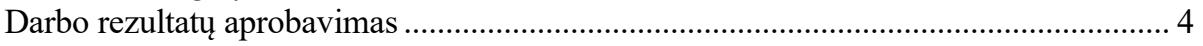

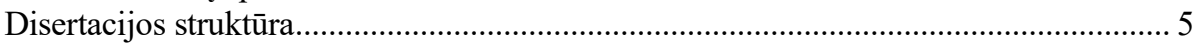

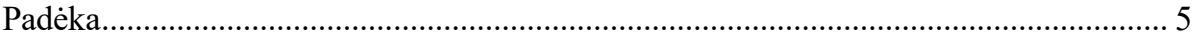

1. UGNIAI ATSPARIŲ MEDŽIAGŲ ŠARMINĖS KOROZIJOS MOKSLINIŲ TYRIMŲ IR PREVENCINIŲ PRIEMONIŲ ANALIZĖ ................................................ 7

1.1. Medienos biokuro naudojimo perspektyvos............................................................ 7

1.2. Biokuro energetinių ịrenginių konstrukcijų išklojų suirimo ypatumai ...................... 8

1.3. Ugniai atsparių medžiagų šarminès korozijos mechanizmas ir jo tyrimų metodai ...... 10

1.4. Aliumosilikatinių medžiagų atsparumas šarminei korozijai .................................... 15

1.5. Ugniai atsparaus betono naudojimo kieto biokuro įrenginių išklojose

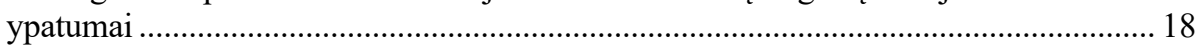

1.6. Ugniai atsparių medžiagų šarminio atsparumo pagerinimo priemonės.................. 21

1.7. Pirmojo skyriaus išvados ir disertacijos uždavinių formulavimas ........................... 23 


\section{NAUDOTOS MEDŽIAGOS IR UGNIAI ATSPARIŲ BETONŲ TYRIMO}

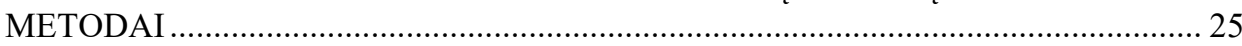

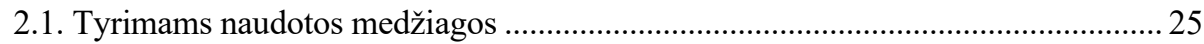

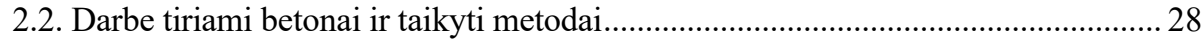

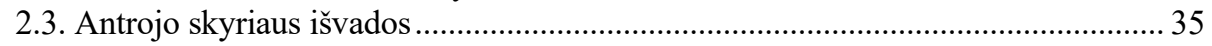

3. ŠAMOTINIŲ UGNIAI ATSPARIŲ BETONŲ SAVYBIŲ IR ŠARMINIO

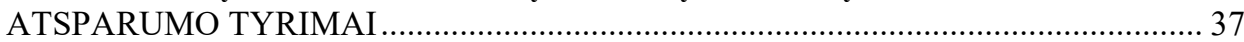

3.1. Šamoto užpildo šarminio atsparumo ịvertinimas panaudojant rentgeno

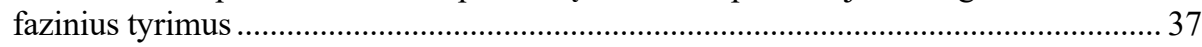

3.2. Ugniai atsparaus betono su šamoto užpildu fizikinių, mechaninių ir terminių

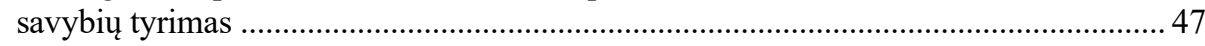

3.2.1 Iprastinio ugniai atsparaus betono, su skirtingais šamoto užpildais ir modifikuojančiais priedais, savybių tyrimai ................................................................ 47

3.2.2. Vidutinio cemento kiekio, ugniai atsparaus betono su skirtingais šamoto užpildais ir malto kvarcinio smèlio priedu, savybiu tyrimai ..................................... 51

3.2.3. Staigaus kaitinimo ir aušinimo poveikis vidutinio cemento kiekio betono

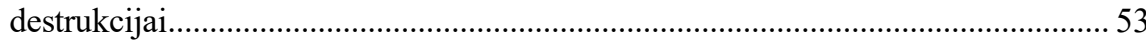

3.3. Betono šarminio atsparumo tyrimai ir jų vertinimas .............................................. 57

3.3.1. Modifikuoto betono šarminis atsparumas.................................................... 57

3.3.2. Modifikuoto vidutinio cemento kiekio betono šarminis atsparumas ............... 62

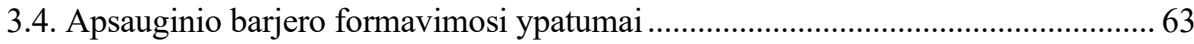

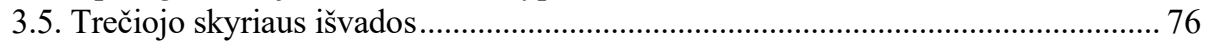

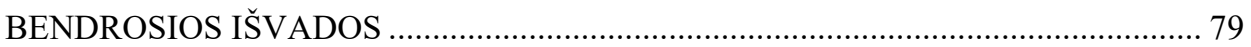

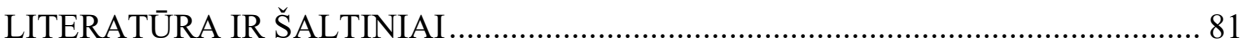

AUTORIAUS MOKSLINIŲ PUBLIKACIJŲ DISERTACIJOS TEMA SĄRAŠAS .... 91

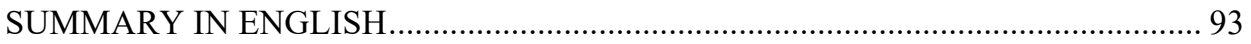

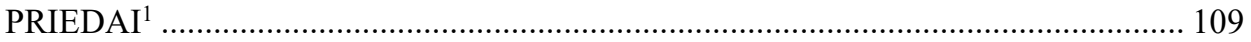

A priedas. Kontrolinio BQ4 ir VCB3 betonų po degimo $1100{ }^{\circ} \mathrm{C}$ temperatūroje ir analogiško betono bandinių paviršiaus sluoksnio po 3 šarminio atsparumo ciklų veikiant $\mathrm{K}_{2} \mathrm{CO}_{3}$, rentgenogramos

B priedas. Autoriaus sąžiningumo deklaracija ......................................................113

C priedas. Bendraautorių sutikimai teikti publikacijose skelbtą medžiagą

daktaro disertacijoje

D priedas. Autoriaus mokslinių publikacijų disertacijos tema kopijos

\footnotetext{
${ }^{1}$ Priedai pateikiami pridètoje kompaktinejje plokštelèje.
} 


\section{Contents}

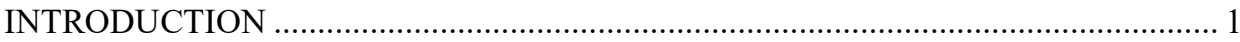

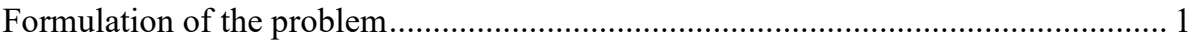

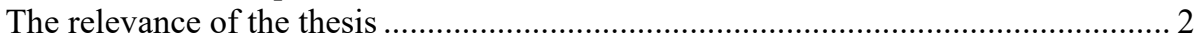

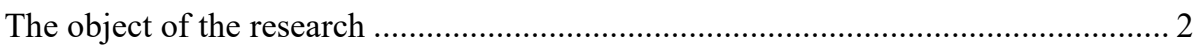

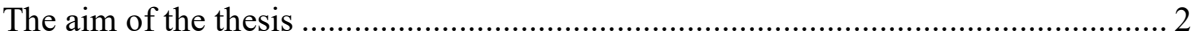

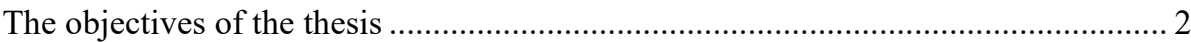

Research methodology ................................................................................. 3

The scientific novelty of the thesis ....................................................................... 3

The practical value of the research findings ........................................................... 4

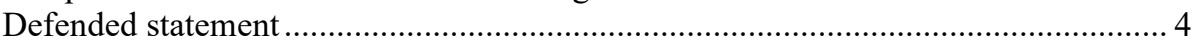

The approval of the research findings .................................................................. 4

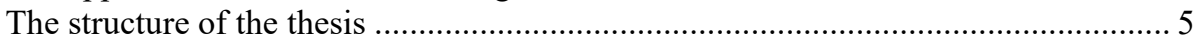

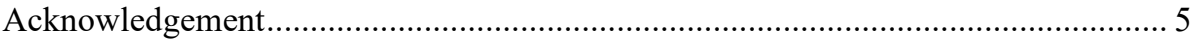

\section{THE ANALYSIS OF SCIENTIFIC RESEARCH WORKS ON ALKALI} CORROSION OF REFRACTORY MATERIALS AND PREVENTION MEASURES. 7

1.1. Prospects for the use of wood biofuels ............................................................. 7

1.2. Peculiarities of destruction of lining of biofuel power plant boiler structures...... 8

1.3. Mechanism of alkaline corrosion of refractory materials and its research method... 10

1.4. Alkali resistance of aluminosilicate materials ................................................. 15

1.5. Use of refractory concrete in the linings of solid fuel installations .................... 18

1.6. Measures to improve the alkali resistance of refractory materials ..................... 21

1.7. Conclusions and formulation of the objectives of thesis .................................... 23 


\section{MATERIALS AND RESEARCH METHODS OF THE}

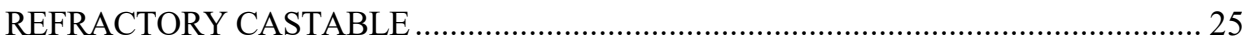

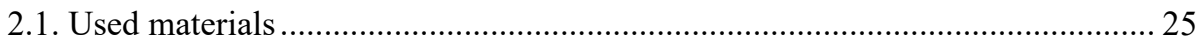

2.2. Compositions of concrete studied in the work and applied methods.................. 28

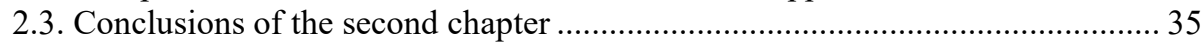

3. INVESTIGATIONS OF PROPERTIES AND ALKALI RESISTANCE OF FIRECLAY REFRACTORY CASTABLE ……………............................................ 37

3.1. Evaluation of alkali resistance of chamotte filler using X-ray studies ............... 37

3.2. Investigation of physical - mechanical and thermal properties of refractory castable with chamotte aggregate ............................................................................... 47

3.2.1. Investigations of properties of conventional refractory castable with different chamotte fillers and effective additives ................................................ 47

3.2.2. Investigations of medium cement castable with different chamotte aggregates and ground quartz sand admixture ................................................... 51

3.2.3. Effect of sudden heating cooling on destruction of medium cement

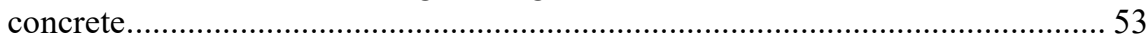

3.3. Standard tests for alkali resistance of castable and its evaluation ...................... 57

3.3.1. Alkali resistance of modified conventional castable................................. 57

3.3.2. Alkali resistance of modified castable with reduced cement content ......... 62

3.4. Investigations of peculiarities of protective barrier formation .......................... 63

3.5. Conclusions of the third chapter .................................................................... 76

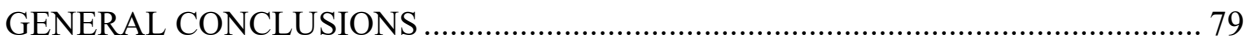

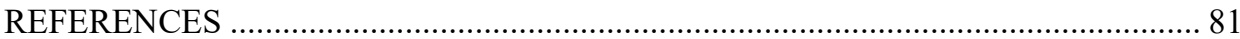

LIST OF SCIENTIFIC PUBLICATIONS BY THE AUTHOR ON THE TOPIC OF

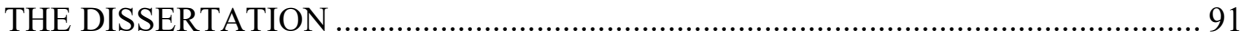

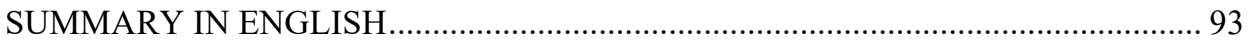

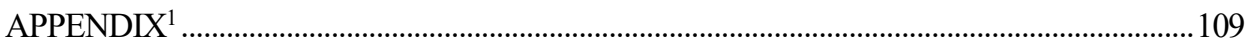

Annex A. X-ray diffraction patterns with characteristic mineral marks

of control BQ4 and VCB3 castable after firing at $1100^{\circ} \mathrm{C}$ and surface layer of analogous castable sample after 3 cycles of alkali resistance under $\mathrm{K}_{2} \mathrm{CO}_{3} \ldots \ldots \ldots \ldots . . .111$

Annex B. Author`s declaration of academic integrity ...........................................113

Annex C. Co-authors` agreements to provide published material in the doctoral dissertation

Annex D. Copies of scientific publications by the author on the topic of the dissertation

\footnotetext{
${ }^{1}$ The annexes are supplied in the enclosed compact disc.
} 


\section{Ivadas}

\section{Problemos formulavimas}

Aliumosilikatinei $\left(\mathrm{Al}_{2} \mathrm{O}_{3}-\mathrm{SiO}_{2}\right)$ sistemai priklausančios ugniai atsparios medžiagos aukštose temperatūrose nèra pakankamai atsparios šarminei korozijai. Tokių medžiagų šarminę koroziją paprastai sukelia kalio/natrio oksidai ir jų druskos, kurios susidaro dèl alternatyvaus kuro (tame tarpe medienos) deginimo.

Šarminè korozija vyksta dèl aliumosilikatinès medžiagos reakcijų su šarminiais garais, lydalu ar kietos būsenos šarminiais junginiais. Susidaro įvairūs korozijos produktai (leucitas, kalsilitas, lauko špatai ir kt.), kurių tūris yra didesnis, lyginant su pradiniu medžiagos tūriu. Tais atvejais, kai šarminis lydalas prasiskverbia ì medžiagos struktūrą, susidaro pakitusios struktūros zonos. Susidarius ịtempiams tarp pradinès ir pakitusios struktūros zonų, ìvyksta medžiagos destrukcija.

Didinant aliumosilikatinių ugniai atsparių betonų šarminį atsparumą, gali būti naudojami priedai, skatinantys apsauginio barjero formavimąsi ir stabdantys šarminio lydalo prasiskverbimą ị medžiagos struktūrą.

Šiam tikslui tyrime naudojamas malto kvarcinio smèlio priedas. Šamotiniuose ugniai atspariuose betonuose, naudojant ši priedą, yra nepakankamai aiškūs barjero formavimosi proceso parametrai, jo savybès bei stabilumas. Taip pat, nežinomas ir kvarcinio smèlio poveikis aukščiau minètų betonų eksploatacinèms savybėms. 


\section{Darbo aktualumas}

Europoje ir Lietuvoje plačiai eksploatuojami kietą biokurą naudojantys energetiniai įrenginiai.

Iprastinių, priklausančių aliumosilikatinių medžiagų grupei, ir plačiai naudojamų pramoninèse krosnyse šamotinių ugniai atsparių medžiagų ilgaamžiškumas tokio tipo irenginiuose dèl šarminès korozijos nèra didelis (trukmè 1-2 metai). Dažnai šių medžiagų parinkimą nulemia kaina, kuri, palyginus su šarminei korozijai atspariomis medžiagomis su silicio karbidu, chromo arba cirkonio oksidais, yra gerokai žemesnè.

Priedai, stabdantys šarminių junginių skverbimąsi ị medžiagą arba ribojantys jų kontaktą, gali žymiai padidinti ịprastinių šamotinių ir kitų aliumosilikatinių medžiagų ir iš jų pagamintų kieto kuro ịrenginių išklojų atsparumą šarminių junginių poveikiui. Modifikuojančiais priedais pagerinus medžiagos savybes ir tokiu būdu padidinus kieto kuro ịrenginių išklojų eksploatavimo trukmę, sumažès medžiagų, reikalingų jas gaminti, ir remontų poreikis.

\section{Tyrimu objektas}

Ugniai atsparus betonas su šamoto užpildais, skirtas kieto biokuro energetinių įrenginių išklojoms.

\section{Darbo tikslas}

Padidinti cementinio ugniai atsparaus betono su šamoto užpildu šarminị atsparumą eksploatuojant kieto biokuro ịrenginius $1100-1200{ }^{\circ} \mathrm{C}$ temperatūroje.

\section{Darbo uždaviniai}

1. Ivertinti skirtingo $\mathrm{Al}_{2} \mathrm{O}_{3} / \mathrm{SiO}_{2}$ santykio $(0,44 ; 0,68 ; 0,89)$ šamoto užpildų šarminị atsparumą $1100-1200{ }^{\circ} \mathrm{C}$ temperatūrose.

2. Nustatyti iprastinio ir vidutinio cemento kiekio ugniai atsparaus šamotinio betono, su skirtingo $\mathrm{Al}_{2} \mathrm{O}_{3} / \mathrm{SiO}_{2}$ santykio šamoto užpildu bei kvarcinio smèlio priedu, fizikines, mechanines ir termines savybes. 
3. Ištirti ịprastinio ir vidutinio cemento kiekio ugniai atsparių betonų su kvarcinio smèlio priedu šarmini atsparumą $1100-1200{ }^{\circ} \mathrm{C}$ temperatūroje ir nustatyti apsauginio barjero, stabdančio šarminę koroziją, formavimosi ypatumus.

\section{Tyrimų metodika}

Ugniai atsparaus betono bandinių paruošimas ir terminis apdorojimas atliktas laikantis LST EN ISO 1927-5:2013 standarto reikalavimų.

Pagrindinès ugniai atsparaus betono savybès šiame darbe buvo nustatytos remiantis LST EN ISO 1927-(4,6-8):2013 standartais. Medžiagos struktūrai vertinti buvo naudojami skenuojančios elektroninès mikroskopijos, rentgenografinès ir ultragarsinès analizès metodai. Ugniai atsparaus betono terminis atsparumas buvo nustatytas pagal ГОСТ 20910-90:2019, atvirasis poringumas pagal LST EN ISO 10545-3:2000, deformacijos temperatūra pagal EN ISO 1893:2009, šarminis atsparumas tiglio metodu pagal ASTM C 45483:2007 standartus. Betono destrukcija dèl staigaus kaitinimo ir aušinimo įvertinta pagal darbo eigoje sukurtą ,vienpusio kaitinimo“" metodiką.

\section{Darbo mokslinis naujumas}

Rengiant disertaciją, buvo gauti šie medžiagų inžinerijos mokslui nauji rezultatai:

1. Nustatyta, kad malto kvarcinio smèlio priedas $1100{ }^{\circ} \mathrm{C}$ temperatūroje padidina iprastinio ir vidutinio cemento kiekio ugniai atsparaus šamotinio betono šarminị atsparumą, nepabloginant kitų eksploatacinių savybių. Nepriklausomai nuo $\mathrm{Al}_{2} \mathrm{O}_{3} / \mathrm{SiO}_{2}$ santykio šamoto užpilde susidaro apsauginis barjeras. Tai rodo, kad maltas kvarcinis smèlis gali būti universali priemonè ir kitų tipų aliumosilikatinių medžiagų šarminio atsparumo didinimui.

2. Pirmą kartą nustatyta, jog apsauginis barjeras susideda iš amorfinių (stiklo) junginių ir kristalinès fazès mineralų. Kristalinė fazè dominuoja prieš amorfinę. Barjerui būdingas diskretiškumas (netolygumas pagal elementinę sudèti). Su kiekvienu ciklu, veikiant kalio karbonatui, šamotiniuose betonuose $1100{ }^{\circ} \mathrm{C}$ temperatūroje lydosi stiklo junginiai ir nustatyti kristaliniai mineralai. Betono paviršiaus reakcijos zonoje formuojasi ne tik amorfiniai naujadarai, bet ir reaguojant su kaliu nustatytiems mineralams susidaro kristaliniai korozijos produktai. Atspariu korozijai betonu atveju 
amorfinių naujadarų kiekis mažèja, o neatsparių betonų - kristalinių korozijos produktų didejja. Ciklinio poveikio metu, lydalui vėstant, ne tik amorfinès stiklo fazès naujadarai, bet ir kristaliniai korozijos produktai palaipsniui uždaro paviršines betono dominuojančias poras ir kapiliarus. Tokiu būdu galima kiekybiškai vertinti barjero stabilumą ir prognozuoti betono šarminị atsparumą.

\section{Darbo rezultatų praktinè reikšmè}

Naujos įprastinio ir vidutinio cemento kiekio aliumosilikatinių betonų sudètys gali būti naudojamos kieto biokuro energetinių irenginių išklojų gamybai keičiant tradicines šamotines medžiagas. Tai leidžia padidinti tokių ịrenginių vidinių konstrukcijų ilgaamžiškumą.

\section{Ginamasis teiginys}

Nepriklausomai nuo $\mathrm{Al}_{2} \mathrm{O}_{3} / \mathrm{SiO}_{2}$ santykio šamoto užpilde, iprastiniame ir vidutinio cemento kiekio betone su malto kvarcinio smèlio priedu, veikiant šarminiam (kalio) lydalui, formuojasi apsauginis barjeras, padidinantis šamotinių betonų šarminį atsparumą.

\section{Darbo rezultatu aprobavimas}

Disertacijos tema paskelbti 4 moksliniai straipsniai: 3 - mokslo žurnaluose, kurie itraukti ì „Clarivate Analytics Web of Science“ duomenu bazę ir 1 - kituose recenzuojamuose leidiniuose.

Disertacijoje atliktų tyrimų rezultatai buvo paskelbti 6 mokslinèse konferencijose Lietuvoje ir užsienyje:

- Jaunujų mokslininkų konferencijoje „Mokslas - Lietuvos ateitis“ 2017 m., 2018 m., 2019 m. Vilnius.

- "International Conference on Refractory and Metallurgy (ICRM2018)“, 2018 m. Rusija.

- „62nd International Colloquium on Refractories 2019“ „Investigation of alkali resistance of fireclay castable with silica sand additive". Vokietija.

- XVIII International Scientific Conference "Refractory materials: Manufacture, methods of testing, application", 2019 m. Lenkija. 


\section{Disertacijos struktūra}

Disertaciją sudaro ịvadas, trys skyriai, bendrosios išvados, literatūros šaltiniai, autoriaus publikacijų disertacijos tema sąrašas ir santrauka anglų kalba bei keturi priedai.

Darbo apimtis yra 110 puslapiai neįskaitant priedų. Rengiant ši darbą panaudota 16 sunumeruotu formulių, 41 paveikslas ir 10 lentelių. Rašant disertaciją buvo panaudota 150 literatūros šaltinių.

\section{Padėka}

Nuoširdžiai dėkoju prof. habil. dr. Romualdui Mačiulaičiui už ekspertinę pagalbą, vertingus patarimus ir pasiūlymus. 



\section{Ugniai atsparių medžiagụ šarminės korozijos mokslinių tyrimų ir prevencinių priemonių analizè}

Skyriuje analizuojami literatūros šaltiniai apie medienos biokurą, kieto biokuro energetinių įrenginių išklojų suirimo ypatumus, ugniai atsparių medžiagų šarminès korozijos mechanizmą ir korozijos tyrimų metodus. Nagrinèjamas aliumosilikatinių medžiagų atsparumas šarminei korozijai, ugniai atsparaus betono panaudojimo kieto biokuro pakurų išklojose ypatumai ir ugniai atsparių medžiagų šarminio atsparumo gerinimo priemonès.

Skyriaus literatūros analizès tematika paskelbti du autoriaus (su bendraautoriais) straipsniai (Zdanevičius et al. 2019; Antonovič et al. 2019).

\subsection{Medienos biokuro naudojimo perspektyvos}

Biokuro naudojimas energijos gamybai Lietuvoje ir visame pasaulyje nuolat dideja. Pavyzdžiui, vertinama, kad Lietuvoje 2020-2025 metais net 75\% šilumos centralizuoto šilumos tiekimo sektoriuje biokuro bus pagaminta iš vietinių atsinaujinančių išteklių. Elektrinèse, naudojančiose medienos biokurą, šiaudus bei išrūšiuotas komunalines atliekas - elektros energijos gamyba sieks 2 TWh (Lietuvos energetikos asociacijos ataskaita 2013; Lietuvos Respublikos 
atsinaujinančių išteklių energetikos ịstatymas, suvestinė redakcija 2020). Ivertinta, kad šiems rodikliams pasiekti bus panaudota - apie 5,37 milijonu kubinių metrų medienos. Tai medžio pramonès atliekos, miško kirtimų metu pagaminama malkinè mediena, miško kirtimo atliekos, mediena gaunama vykdant želdynų, sodų, pakelių, pagriovių tvarkymą ir kt.

Toks didelis medienos panaudojimas kuro gamybai pasidare imanomas atsiradus efektyvioms deginimo technologijoms (pvz. „,verdančio sluoksnio“).

Reikia pažymèti, kad biokuro savybès ir cheminè sudètis ženkliai skiriasi nuo iškastinio kuro charakteristikų. Dèl to, skirtingai nuo iškastinio kuro, susidarantys biokuro degimo produktuose agresyvūs komponentai (ypač šarminiai metalai, chloras, siera) sukèlè rimtų iššūkių tokio kuro naudojimui energetiniuose ịrenginiuose. Didelę įtaką degimo intensyvumui ir susidarantiems produktams, kaip nustatyta specialiais tyrimais, turi dujiné degimo aplinka, kuri biokuro įrenginiuose gali būti kintanti: oksidacinè arba redukcinè (Jefimovas 2015). Neabejotinai degimo metu stebimas įrenginių užterštumo procesas, vidinių konstrukcijų šlakavimasis, vyksta naudojamų ugniai atsparių medžiagų korozija (Jenkins et al. 1998; Zevenhoven-Onderwater et al. 2001). Dèl šiu procesų mažèja pačio ịrenginio efektyvumas, vyksta neplanuoti biokatilinių sustabdymai, reikia skirti papildomų lèšų remontui (Li et al. 2017). Sprendžiant šias ir kitas kieto biokuro naudojimo problemas, nuolat tobulinamos degimo technologijos ir modernizuojami energetiniai įrenginiai (Jansenboiler.com 2020; Sigmathermal.com 2020). Didelis dėmesys skiriamas ir naujų ugniai atsparių medžiagų kūrimui.

\subsection{Biokuro energetinių irenginių konstrukciju išklojų suirimo ypatumai}

Kieto biokuro energetinių ịrenginių pakurose, kuriose naudojamos šiuolaikinès degimo technologijos, vidinès konstrukcijos (išklojos) patiria apkrovas, susijusias su aukšta temperatūra, kuro deginimo metu susidarančiu šarminiu lydalu ir šarminiais garais, terminiais smūgiais (stabdant ir paleidžiant ịrenginį), abrazyviniu kietujų dalelių srautu, mechaniniu poveikiu (valant pelenus ir šlakus) ir kt. (Antonovič et al. 2019).

Kompleksinis visų apkrovų poveikis ugniai atsparių medžiagų ir išklojų ilgaamžiškumui tokio tipo ịrenginiuose pasidaro reikšmingas per sąlyginai ilgą jų eksploatacijos periodą. Pasitaiko atvejų, kai tokių irenginių išklojos suyra po vienerių ar dvejų metų eksploatacijos (Jacob-Lopes et al. 2017; Antonovič et al. 2019). Šiuo atveju, įvertinant visų apkrovų poveiki išklojos greitam suirimui, cheminis šarminių junginių poveikis, sukeliantis naudojamų ugniai atsparių medžiagų koroziją, yra lemiamas. 
Ugniai atsparių medžiagų cheminė korozija (viena iš kurių šarminė) susieta su terminiu ir mechaniniu medžiagos suirimu, kuris gali būti pagreitintas arba sulètintas priklausomai nuo įvairių faktorių. Šiems faktoriams priskiriami ugniai atsparių medžiagų nusidèvejjimą lemiantys parametrai (1.1 pav.) (Poirier et al. 2017). Matome (1.1 pav.), kad medžiagos nusidèvejjimas dèl cheminès korozijos (ir kt. apkrovu) priklauso nuo medžiagos struktūros, cheminès sudèties, jos fizikinių ir mechaninių savybių. Svarbūs yra ir pačio įrenginio išklojos konstrukcijos parametrai, eksploatacijos sąlygos bei cheminių junginių, sukeliančių koroziją, charakteristikos. Kieto biokuro energetiniuose įrenginiuose koroziją sukeliantys šarminiai metalai (kalis $(\mathrm{K})$, natris $(\mathrm{Na})$ ) susidaro medienos kuro degimo metu, jų bendras kiekis pelenuose (priklausomai nuo medienos rūšies) sudaro apie $1 \%$ (Jefimovas 2015). Medienos pelenuose K yra 2-4 kartus daugiau negu $\mathrm{Na}$ ir jo difuzija ị ugniai atsparių medžiagų struktūrą yra žymiai didesnè. Pavyzdžiui, nustatyta, kad kalio prasiskverbimas ị aukštakrosnès išklojos medžiagą buvo apie $20 \%$ didesnis palyginus su natriu (Narita et al. 1981). Taip pat komunalinių atliekų deginimo krosnyje naudojamų SiC plokščiu tyrimai parodè, kad K prasiskverbė apie 3 kartus giliau ị šios medžiagos struktūrą nei Ca. Na prasiskverbimas buvo minimalus per visą išklojos storị (Poirier 2019). Tai rodo, kad kalis turi didesni potencialą sukelti ankstyvą aliumosilikatinių medžiagų koroziją.

\begin{tabular}{|c|c|c|c|c|c|}
\hline \multirow{2}{*}{\multicolumn{2}{|c|}{$\begin{array}{l}\text { Charakteristikos } \\
\text { Šiluminis laidumas }\end{array}$}} & \multirow{4}{*}{$\begin{array}{c}\text { Sandara } \\
\text { Poringumas } \\
\text { Porų skaičius, } \\
\text { skersmuo ir jų } \\
\text { pasiskirstymas }\end{array}$} & \multicolumn{3}{|c|}{ Cheminès charakteristikos } \\
\hline & & & \multirow{3}{*}{$\begin{array}{l}\text { Cheminè } \\
\text { sudètis }\end{array}$} & \multirow{3}{*}{$\begin{array}{l}\text { Kristalinès } \\
\text { fazès }\end{array}$} & \multirow{3}{*}{$\begin{array}{l}\text { Kristalu kiekis ir jų } \\
\text { dydis }\end{array}$} \\
\hline \multicolumn{2}{|c|}{ Terminis išsiplètimas } & & & & \\
\hline \multicolumn{2}{|c|}{ Mechaninis stipris } & & & & \\
\hline \multicolumn{2}{|c|}{ Savitasis svoris } & \multirow{2}{*}{ Pralaidumas } & \multirow{2}{*}{$\begin{array}{l}\text { Mineraloginè } \\
\text { sudètis }\end{array}$} & \multirow{2}{*}{ Stiklo fazès } & \multirow{2}{*}{$\begin{array}{c}\text { Stiklo fazès kiekio } \\
\text { pasiskirstymas sudètyje }\end{array}$} \\
\hline & xtai & & & & \\
\hline \multirow{2}{*}{\multicolumn{2}{|c|}{ Išklojos charakteristikos }} & \multirow{7}{*}{$\begin{array}{r}\text { UGNIAI A] } \\
\text { MEDŽI } \\
\text { DE்VĖJI }\end{array}$} & \multirow{6}{*}{$\lambda$} & \multicolumn{2}{|c|}{ Eksploatacijos sąlygos } \\
\hline & & & & \multicolumn{2}{|c|}{ Technologiniai procesai } \\
\hline \multirow{3}{*}{\multicolumn{2}{|c|}{$\begin{array}{c}\text { Storis } \\
\text { Izoliacija } \\
\text { Temperatūros gradientas }\end{array}$}} & & & $\begin{array}{c}\text { Temperatūra } \\
\text { Aplinkos tipas }\end{array}$ & Vidutiniai pokyčiai \\
\hline & & & & \multirow{4}{*}{$\begin{array}{c}\text { Koroziją } \\
\text { sukeliančių } \\
\text { reagentų } \\
\text { charakteristikos }\end{array}$} & Sudètis \\
\hline & & & & & Kiekis \\
\hline Siūlès & $\begin{array}{l}\text { Medžiagos } \\
\text { išsinlėtimas }\end{array}$ & & & & $\begin{array}{c}\text { Klampa } \\
\text { Drėkinimo }\end{array}$ \\
\hline \multicolumn{2}{|c|}{ Konstrukcija } & & & & Joninė poliarizacija \\
\hline \multicolumn{2}{|c|}{ Erozija } & siskverbimas & \multicolumn{2}{|c|}{ Korozija } & Terminiai smūgiai \\
\hline
\end{tabular}

1.1 pav. Ugniai atsparių medžiagų nusidèvejimą lemiantys faktoriai

(Poirier et al. 2017)

Fig. 1.1. Factors determining the wear of refractory materials

(Poirier et al. 2017) 
Pastebèta (Antonovič et al. 2019), kad biokuro įrenginių išklojos medžiagų (dažniausiai aliumosilikatinių) pagreitintas suirimas nuo šarminių junginių poveikio vyksta susiklosčius tam tikroms eksploatacijos sąlygoms temperatūroms, pasiekus artimą pelenų minkštèjimo temperatūrą ir besiformuojant didesniam pelenų lydalo bei šlako kiekiui. Pavyzdžiui, naudojant pušies skiedras arba pjuvenas, išklojos medžiagų korozijos grèsmè padidèja, kai temperatūra energetiniame įrenginyje siekia apie $1200^{\circ} \mathrm{C}$. Pelenai šioje temperatūroje suminkštèja (1.1 lentelè) ir intensyviai limpa prie išklojos paviršiaus. Naudojant kitas medienos kuro rūšis (pvz. žieves), pelenų minkštejjimo temperatūra yra gerokai didesnè ir, esant maksimaliai (trumpalaikei) eksploatacinei biokuro ịrenginių temperatūrai $\leq 1200{ }^{\circ} \mathrm{C}$, cheminis poveikis medžiagų ilgaamžiškumui ịvertinant ir kitas eksploatacines apkrovas, nèra lemiamas.

Siekiant išvengti cheminès korozijos pasekmių, projektuojant ir parenkant ịrenginio konstrukciją bei ugniai atsparias medžiagas biokuro katilų išklojai, turi būti ìvertintos ne tik cheminių reagentų ir ugniai atsparių medžiagu charakteristikos, bet ir visi kiti 1.1 paveiksle išvardinti faktoriai.

1.1 lentelė. Medžio pelenų lydymosi charakteristikos (Vares et al. 2007)

Table 1.1. Melting characteristics of wood ash (Vares et al. 2007)

\begin{tabular}{|l|c|c|c|c|}
\hline \multirow{2}{*}{ Medienos biokuro rūšis } & \multicolumn{4}{|c|}{ Pelenų lydymosi charakteristikų vertès, ${ }^{\circ} \mathrm{C}$} \\
\cline { 2 - 5 } & $\begin{array}{c}\text { Pradinis } \\
\text { deformacijos } \\
\text { taškas }\end{array}$ & $\begin{array}{c}\text { Minkštejjimo } \\
\text { temperatūra }\end{array}$ & $\begin{array}{c}\text { Pusrutulio } \\
\text { susidarymo } \\
\text { taškas }\end{array}$ & $\begin{array}{c}\text { Išsiliejimo } \\
\text { taškas }\end{array}$ \\
\hline Pušies skiedros & 1210 & 1225 & 1250 & 1275 \\
\hline Kirtimo atliekų skiedros & 1175 & 1205 & 1230 & 1250 \\
\hline Pušies pjuvenos & 1150 & 1180 & 1200 & 1225 \\
\hline Eglès žievė & 1405 & 1550 & 1650 & 1650 \\
\hline Pušies žieve & 1340 & 1525 & 1650 & 1650 \\
\hline
\end{tabular}

\subsection{Ugniai atsparių medžiagu šarminès korozijos mechanizmas ir jo tyrimų metodai}

Šarminė korozija vyksta ịvairiose statybinèse medžiagose, t. y., skirtose ịprastinėms statybinèms konstrukcijoms ir konstrukcijoms, naudojamoms aukštoje temperatūroje.

Naudojamų betonų su portlandcemenčiu užpildų šarminė korozija vyksta reaguojant cemente esantiems natrio ir kalio hidroksidams (šarmams) su 
amorfiniu $\mathrm{SiO}_{2}$. Reakcija vyksta lètai ir konglomerato irimo požymiai atsiranda tik po kelių mėnesių ar metų (Skripkiūnas 2007). Cementinio akmens sluoksnis apie reaktyvius užpildus sudaro pusiau laidžią membraną, per kurią šarminių metalų hidratai difunduoja ị reakcijos zoną, o reakcijos produktams ši membrana nelaidi. Besikaupiantys reakcijos produktai aplink reaktyvaus užpildo daleles sudaro dideli slègị, kuris sukelia konglomerato irimą. Susidaręs slègis priklauso nuo šarmų kiekio cemente, užpildų reaktyvumo ir kitų veiksnių. Esant nedideliam kiekiui reaktyvių dalelių užpilde, konglomerato paviršiuje atsiranda lokaliniai defektai - cemento akmens nuskilimai iki reaktyvaus užpildo. Tam, kad vyktų šarminè korozija, cemente turi būti pakankamai didelis šarmų kiekis, o užpilduose turi būti tam tikras kiekis reaktyvių dalelių (turinčių aktyvaus $\mathrm{SiO}_{2}$ ). Reaguoti su cemente esančiais šarmais gali tokie mineralai kaip tridimitas, kristobolitas ir kt. (Skripkiūnas 2007).

Ugniai atsparių medžiagų (ir ne tik cementinių) šarminè korozija aukštose temperatūrose yra rimta problema pramoniniams ịrenginiams. Tokių šiluminių ịrenginių, kaip kieto biokuro katilų, ịvairių atliekų deginimo pakurų, aukštakrosnių ar žemakrosnių, stiklo lydymo ir cemento krosnių, dujų sintezavimo aparatų bei kt. išklojos, pagamintos iš ugniai atsparių medžiagų, patiria agresyvų šarminių junginių poveikį. Dẻl to gerokai sumažèja visų šių ịrenginių konstrukcijų ilgaamžiškumas (Caprio et al. 1982; Fischer et al. 2008; Dominguez et al. 2010: 18; Schaafhausen et al. 2013). Šilumos irrenginiu konstrukcijų irimo laipsnis (1.2 pav.) yra gerokai didesnis negu statyboje naudojamų betonų irimas dèl užpildų šarminès korozijos (Vektaris et al. 2006).

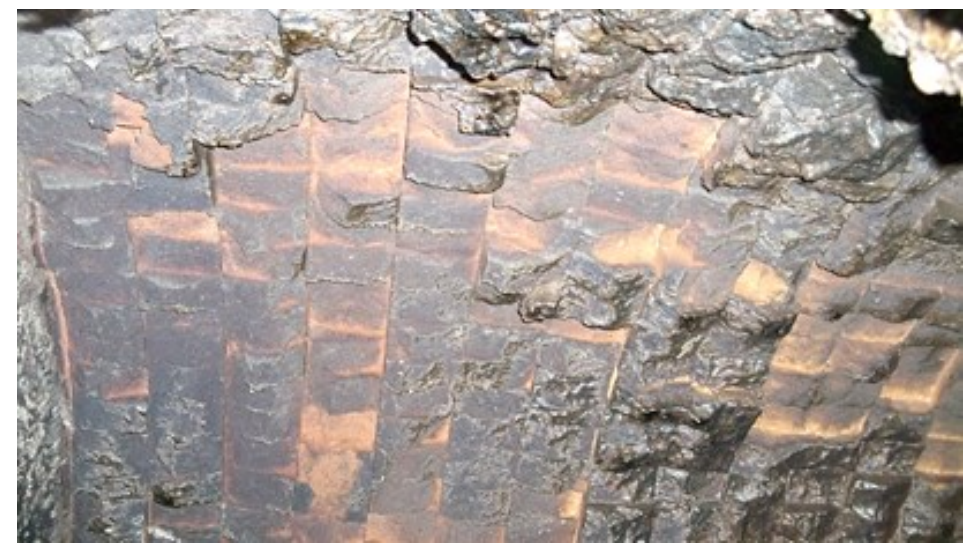

1.2 pav. Šamoto plytų sluoksniavimasis po 6 mèn. eksploatacijos biokuro katile (Jacob-Lopes et al. 2017)

Fig. 1.2 Spalling of fireclay bricks after 6 month of biomass boiler operation (Jacob-Lopes et al. 2017) 
Energetiniuose (biokuro) įrenginiuose deginant medienos kurą, iš degimo produktų išsiskiria šarminiai natrio ir kalio metalai, sukeliantys ugniai atsparių medžiagų šarminę koroziją. Prieš tai įvyksta ir pačių šarminių ir kitų metalų cheminè dujinė korozija aukštoje temperatūroje sąveikaujanti su $\mathrm{O}_{2}, \mathrm{CO}, \mathrm{CO}_{2}$, $\mathrm{SO}_{2}$ dujomis ir vandens garais (Kerienè 2014).

Išoriniai faktoriai, turintys ịtakos metalų aukštatemperatūrès dujinès korozijos greičiui: a) dujų cheminè sudètis, slègis, temperatūra; b) dujų srauto judejimo greitis, sąlyčio su metalo paviršiumi trukmè; b) metalo kaitinimo dujinèje aplinkoje režimas. Didinant temperatūrą, didèja dujinès metalų korozijos greitis. Dèl temperatūros svyravimų susidaro vidiniai ịtempiai. Didinant deguonies dalinị slègị, daugelio metalų oksidacijos aukštoje temperatūroje greitis didèja, o pasiekus tam tikrą kritinę deguonies dalinio slègio reikšme labai sumažèja ir toliau didinant deguonies dalinị slègị, greitis lieka labai nedidelis. Dauguma metalų aukštoje temperatūroje reaguoja su $\mathrm{O}_{2}, \mathrm{H}_{2} \mathrm{O}, \mathrm{CO}_{2}$, $\mathrm{SO}_{2}, \mathrm{Cl}_{2}$ ir kt. Agresyviąsias dujas pagal jų sukeliamos metalų oksidacijos $900{ }^{\circ} \mathrm{C}$ temperatūroje greitị galima surašyti ị tokią eilę: $\mathrm{H}_{2} \mathrm{O}<\mathrm{CO}_{2}<\mathrm{O}_{2}<\mathrm{SO}_{2}$ (Kerienè 2014).

Ugniai atsparių medžiagų šarminè korozija paprastai vyksta dèl:

- ugniai atsparios medžiagos ištirpimo ir sąveikos kontakte su šarminiu lydalu (toliau - 1 korozijos tipas);

- reakcijos su šarminiais garais, lydalu ar kietos būsenos šarminiais junginiais (2 korozijos tipas);

- šarminių garų arba lydalo skverbimosi ị medžiagos poras susidarant pakitusios struktūros zonai (3 korozijos tipas). (Nishikawa 1984; Brachhold et al. 2017).

Ugniai atsparios medžiagos tirpimas ir sąveika (1 korozijos tipas) veikiant lydalui, gali būti ịvertintas panaudojant fazines diagramas ir atsižvelgiant ị ugniai atsparios medžiagos bei lydalo sudètị (Jesse et al. 1995). Biokuro ịrenginiuose, esant temperatūrai $>1300^{\circ} \mathrm{C}$, toks korozijos mechanizmas yra dažnas.

Pavyzdžiui, pakuroje, deginant medžio dulkes, kurios gautos jų šlifavimo metu, susidaro didelis šarminių pelenų lydalo kiekis, intensyviai tirpdandis pakuros šamoto plytų paviršinị sluoksnị (Гоберис et al. 2003).

Korozijos atsiradimo grèsmè dèl ugniai atsparios medžiagos tirpimo kieto biokuro energetinių ịrenginių pakurose yra labai maža, nes tokiuose įrenginiuose pakankamai žemos eksploatacijos temperatūros $\left(900-1100^{\circ} \mathrm{C}\right)$. Aukštos lokalinès temperatūros $\left(\sim 1200^{\circ} \mathrm{C}\right)$ tokiuose ịrenginiuose yra trumpalaikès, todèl nèra galimybės susidaryti dideliems šarminio lydalo kiekiams.

Ugniai atsparių medžiagų cheminès korozijos reakcijos (2 korozijos tipas) vyksta kietose fazèse (medžiaga - šarminis junginys), tarp kietos (ugniai atspari medžiaga) - skystos (lydalas) ir kietos - dujinès fazès. 
Reakcijos greitis kietose fazėse priklauso nuo cheminės reakcijos kontakte tarp reagentų ir nuo jų komponentų difuzijos per reakcijos produktų sluoksnị. Daugelyje atvejų reakcijos greitis priklauso nuo difuzijos greičio pagal pirmą Fiko dèsnị:

$$
J=-D \nabla n,
$$

čia $J$-medžiagos kiekio srauto tankis; $D$-difuzijos koeficientas; $\nabla$ koncentracijos gradientas; $n$ - molinė koncentracija. Minuso ženklas rodo, kad difuzija vyksta koncentracijos mažejimo kryptimi (Адамсон 1979; Фролов 1982; Nishikawa 1984; Balandis et al. 2006; Balandis et al. 2007).

Arenijaus lygtis (Ragelienè et al. 2011) rodo, kaip cheminès reakcijos greitis eksponentiškai priklauso nuo temperatūros:

$$
k=A \cdot e^{-\frac{E_{a}}{R T}}
$$

čia $k$-reakcijos greičio konstanta; $A$-Arenijaus konstanta (apibūdinanti kiekvieną konkrečią reakciją); $E a$-aktyvacijos energija; $R$-universalioji (molinè) dujų konstanta; $T$ - temperatūra.

Nustatyta, kad išklojos medžiagos ir skystos arba garų fazès reagento reakcijos vyksta panašiai kaip ir kietujų fazių sąveikos atveju. Tokių reakcijų greitis priklauso nuo difuzijos (kai skystos arba dujinès medžiagos molekulès skverbiasi iš didesnès koncentracijos vietų link mažesnès koncentracijos) spartos per sureagavusị sluoksnį, nuo cheminès reakcijos tarp medžiagos ir sureagavusio sluoksnio bei difuzijos per tarpfazinị sluoksnị (interfacial film) (1.3 pav., Nishikawa 1984). Dujų arba skystos fazès koncentracija yra pastovi $(n=$ konstanta), tarpfaziniame sluoksnyje ji kinta pagal logaritminę kreivę iki $n_{s}$, o sureagavusiame sluoksnyje pagal tiesinę priklausomybę iki $n_{i}$.

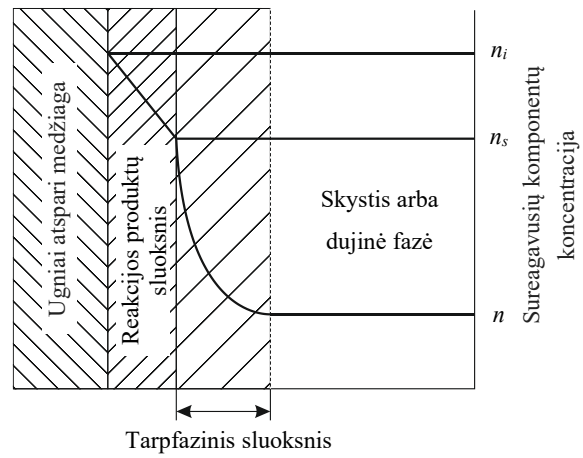

1.3 pav. Medžiagos ir skystos arba medžiagos ir garų fazės reakcijų schema (Nishikawa 1984)

Fig. 1.3. Scheme for the reaction of substances and liquids or substances and vapors

(Nishikawa 1984) 
Ugniai atsparios medžiagos mineralų tūris pasikeičia reakcijose su šarminiais junginiais (dažniausiai padidèja), atsiranda kritiniai įtempiai ir medžiaga suyra (Nishikawa 1984).

Lydalui prasiskverbus ị medžiagą (3 korozijos tipas), formuojasi ir susidaro pakitusios struktūros zonos. Dẻl skirtingų tokios zonos ir pagrindinès medžiagos deformacijos charakteristikų vyksta medžiagos sluoksniavimasis ir tai sąlygoja išklojų sluoksnių irimą. Bennett et al. (2003) pateikè tokio tipo medžiagos korozijos irimo mechanizmą (1.4 pav.), detaliai aprašydamas destrukcijos procesą.

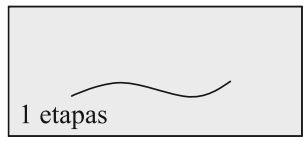

a)

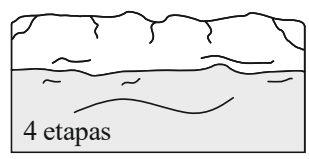

d)

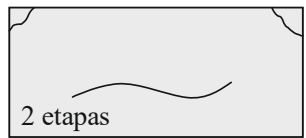

b)

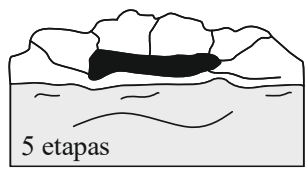

e)

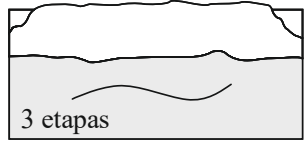

c)

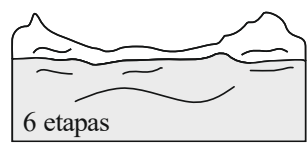

f)

1.4 pav. Ugniai atsparios medžiagos irimas dèl korozijos: a) susidarę mikroịtrūkiai gamybos metu; b) pirmo kaitinimo destrukcija dèl vidinių itempių; c) lydalo prasiskverbimas ị medžiagos paviršinị sluoksnį; d) horizontalių įtrūkių formavimasis;

e) tuštumų formavimasis; f) naujo ciklo pradžia, 3-5 etapo kartojimas (Bennett et al. 2003)

Fig. 1.4. Modeling of the decomposition of a refractory material due to corrosion:

a) microcracks formed during manufacture; b) destruction of first heating due to internal stresses; c) penetration of the melt into the surface layer of the material; d) formation of

horizontal cracks; e) formation of voids; f) start of a new cycle, repeat of steps 3-5

(Bennett et al. 2003)

Ardantysis viršslègis (dèl difuzijos) yra tiesiai proporcingas skysčio paviršiaus ịtempimui, jo kontaktiniam kampui tarp ugniai atsparios medžiagos ir skysčio bei atvirkščiai proporcingas vidutiniam porų spinduliui. Tai išreiškiama lygtimi:

$$
\Delta P=\frac{2 \gamma_{L} \cdot \cos \theta}{r},
$$

čia: $\Delta P$ - viršslègis; $\gamma_{L}$ - skysčio paviršiaus įtempis; $\theta$ - kontaktinis kampas; $r$ - vidutinis poru spindulys (Адамсон 1979; Лыков 1978; Фролов 1982; Balandis et al. 2006; Balandis et al. 2007).

Aukštose temperatūrose lydalo prasiskverbimas priklauso nuo medžiagos poringumo, porų formos ir dydžio, pačio lydalo klampio, paviršiaus įtempio bei jo drèkinimo kampo, kapiliarų potencialo ir kt. Prasiskverbusio lydalo tūris gali būti apskaičiuotas pagal šią formulę (Nishikawa 1984; Perkoa et al. 2020): 


$$
V=A\left(\frac{1}{2} P^{2} r\left(\frac{\gamma_{L}}{\eta}\right) \cdot \cos \theta \cdot t\right)^{\frac{1}{2}},
$$

čia: $V$ - prasiskverbusio lydalo tūris; $A$ - prasiskverbusio lydalo paviršiaus plotas; $P$ - atviras poringumas; $r$ - vidutinis poru spindulys; $\gamma_{L}-$ lydalo paviršiaus ịtempis; $\eta$ - lydalo klampis; $\theta$ - kontaktinis kampas; $t$ - laikas.

Atsižvelgiant i pateiktą priklausomybę aišku, kad prasiskverbimas ir korozijos pasekmès gali būti kontroliuojamos valdant lydalo charakteristikas (ko dažnai neįmanoma padaryti) arba pačios medžiagos struktūros modifikavimą. Taip pat gali būti naudojamos ir apsauginès išorinès dangos (Lee et al. 1999).

Tiriant medžiagų šarminị atsparumą laboratorinėmis sąlygomis, praktiškai neįmanoma imituoti šilumos įrenginio realių eksploatavimo sąlygų.

Pavyzdžiui, sudėtinga sudaryti analogišką dujinę aplinką (parinkti vandens garų, šarminių ir kt. junginių dujų koncentracijas) konkrečiam ịrenginiui. Be to, tyrimo metu vyksta ir intensyvus laboratorinès įrangos dejvèjimasis. Dèl šių priežasčių ugniai atsparių medžiagų atsparumą šarminiams junginiams įvertinti dažniausiai naudojami termodinaminiai skaičiavimai arba eksperimentinis „tiglio“ metodas. Termodinaminiai skaičiavimai (Rezaie et al. 2004; Zhao et al. 2018) atliekami pasitelkiant šiuolaikines programas, pvz. tokias kaip „FactSage“, „Pandat“, ,Thermo-Calc“" ir kt.

„Tiglio“ metodo eksperimentiniuose tyrimuose, siekiant išvengti šarminių junginių garavimo nuostolių ir sumažinti laboratorinès įrangos dejvejjimąsi, bandinio ertmė su šarminiu reagentu uždengiama tos pačios medžiagos plokštele. Dažniausiai, kaip šarminę koroziją sukeliantys reagentai, naudojamos šarminès druskos (karbonatai), (Poirier et al. 2017 c). ASTM C 454 standartas rekomenduoja naudoti $\mathrm{K}_{2} \mathrm{CO}_{3}$. Taip pat gali būti naudojami $\mathrm{Na}_{2} \mathrm{CO}_{3}$ arba $\mathrm{K}_{2} \mathrm{CO}_{3}$ ir $\mathrm{Na}_{2} \mathrm{CO}_{3}$ mišinys.

\subsection{Aliumosilikatinių medžiagų atsparumas šarminei korozijai}

Aliumosilikatinès ugniai atsparios medžiagos remiasi $\mathrm{Al}_{2} \mathrm{O}_{3}-\mathrm{SiO}_{2}$ sistema. Šios sistemos pusiausvyros diagrama pateikta 1.5 paveiksle (Surendranathan 2015). Jai priklauso įvairios aliumosilikatinès ugniai atsparos medžiagos (tame tarpe ir šamotas). Šamote vyrauja kvarcas, kristobalitas, tridimitas, mulitas (Sadik et al. 2014). Priklausomai nuo šamoto sudèties kinta ir jo panaudojimo temperatūra ji didèja didèjant $\mathrm{Al}_{2} \mathrm{O}_{3}$ kiekiui (1.5 pav.). Reikia taip pat pažymėti, kad šamoto sudètyje yra ir apie $20 \%$ stiklo fazès (Didier-Werke 1989).

Lyginant aliumosilikatinès sistemos medžiagų šarminị atsparumą, firmos „Hasle-Refractories“ techninèje ataskaitoje (Butzbach 2019) nurodoma, kad 
didejjant aliuminio oksido kiekiui medžiagoje jos atsparumas šarminei korozijai sumažejja, nors medžiagos atsparumas ugniai ir padidejja. Tai reiškia, kad korozijos reakcijų eiga priklauso nuo $\mathrm{Al}_{2} \mathrm{O}_{3} / \mathrm{SiO}_{2}$ santykio. Kai šis santykis yra mažesnis nei 1 , reakcijų vyksme šarminis lydalas formuojasi sąlyginai žemose temperatūrose - apie $1000^{\circ} \mathrm{C}$ (su kaliu eutektika susidaro jau $985^{\circ} \mathrm{C}$ ) (Leupold et al. 1984; Szczerba et al. 2005). Kitais atvejais šarminès korozijos eigą galima ìvertinti pagal $\mathrm{K}_{2} \mathrm{O}-\mathrm{SiO}_{2}-\mathrm{Al}_{2} \mathrm{O}_{3}$ trikompontès sistemos diagramos būseną (Scudeller et al. 1990).

Nustatyta, kad šarminiai junginiai, prasiskverbdami ị aliumosilikatinę medžiagą, pirmiausiai reaguoja su medžiagos stiklo faze, vèliau su mulitu (Luis et al. 1990). M. Carlborg (Carlborg et al. 2013) nustatè, kad šarminių metalų jonai lengviausiai skverbiasi ị matricą, joje kaupiasi ir tik tada reaguoja su medžiagos užpildu.

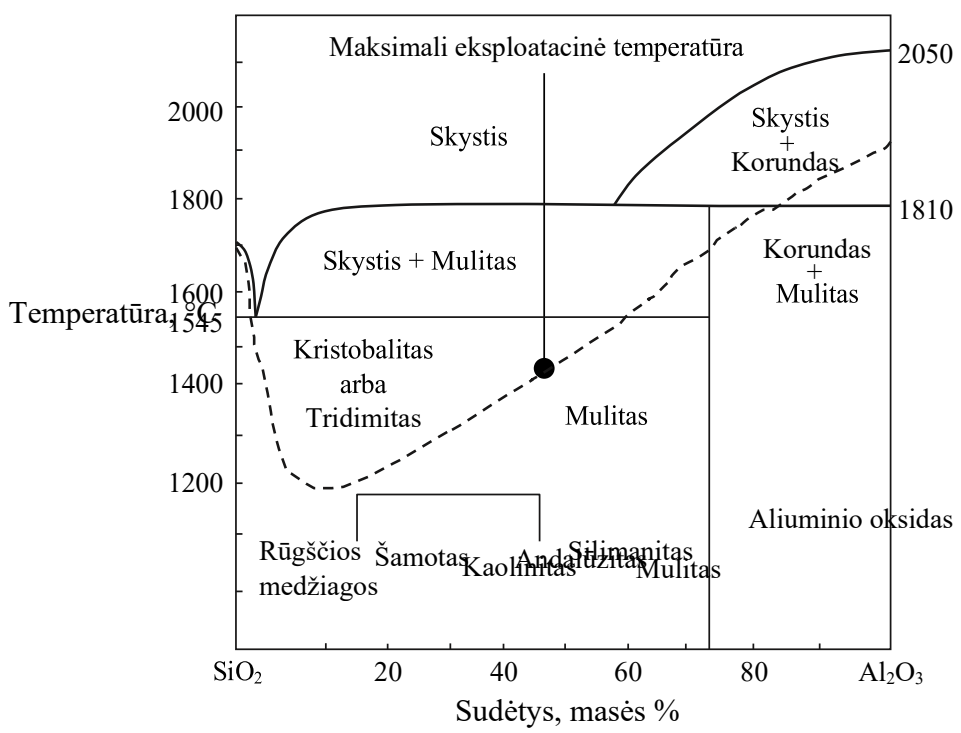

1.5 pav. $\mathrm{Al}_{2} \mathrm{O}_{3}-\mathrm{SiO}_{2}$ sistemos fazinè diagrama ir jai priklausiančios ugniai atsparios medžiagos (Surendranathan 2015)

Fig. 1.5. $\mathrm{Al}_{2} \mathrm{O}_{3}-\mathrm{SiO}_{2}$ system phase diagram and its associated refractory materials (Surendranathan 2015)

Naudojant aliumosilikatines medžiagas kieto biokuro energetiniuose ịrenginiuose, korozinès reakcijos vyksta „sausoje aplinkoje“, veikiant šarmų garams, arba drègnoje aplinkoje, kai ugniai atsparios medžiagos paviršiuje formuojasi pelenų lydalas. 
„Sausos aplinkos“ atveju, išsiskyręs iš medienos kuro dujų pavidalo kalis (ar natris), reaguoja su CO dujomis (Pitac et al. 1991; Riedl et al. 1999).

$$
\begin{aligned}
& 2 \mathrm{~K}+\mathrm{CO} \rightarrow \mathrm{K}_{2} \mathrm{O}+\mathrm{C}, \\
& 2 \mathrm{~K}+3 \mathrm{CO} \rightarrow \mathrm{K}_{2} \mathrm{CO}_{3}+2 \mathrm{C}, \\
& \mathrm{K}_{2} \mathrm{CO}_{3}+\mathrm{CO} \rightarrow 2 \mathrm{~K}+2 \mathrm{CO}_{2}\left(>930{ }^{\circ} \mathrm{C}\right. \text {; kalis - garų būsenoje). }
\end{aligned}
$$

Kalis garų būsenoje kondensuojasi gilesniame išklojos medžiagos sluoksnyje.

Kaip nurodo (Poirier 2019) darbo autoriai, dèl susidariusio išklojos konstrukcijoje temperatūrinio gradiento, tai yra medžiagos zona, kurioje temperatūra siekia $600-850^{\circ} \mathrm{C}$.

Kondensuojantis garo būsenos šarminiam komponentui aliumosilikatinèje medžiagoje, gali susidaryti tokie korozijos produktai: leucitas $\left(\mathrm{K}_{2} \mathrm{O} \cdot \mathrm{Al}_{2} \mathrm{O}_{3} \cdot 4 \mathrm{SiO}_{2}\right)$, kalsilitas $\left(\mathrm{K}_{2} \mathrm{O} \cdot \mathrm{Al}_{2} \mathrm{O}_{3} \cdot 2 \mathrm{SiO}_{2}\right)$, lauko špatai ( $\mathrm{KAlSi}_{3} \mathrm{O}_{8}$ $\mathrm{NaAlSi}_{3} \mathrm{O}_{8}-\mathrm{CaAl}_{2} \mathrm{Si}_{2} \mathrm{O}_{8}$ ) ir kt. (Tassot et al. 2003; Jacob-Lopes et al. 2017).

Kai temperatūroje $\sim 1200^{\circ} \mathrm{C}$ (kieto kuro irenginiuose lokalinè ir trumpalaikè) ugniai atsparios medžiagos paviršiuje formuojasi lydalas, („drėgnos aplinkos atvejis“) gali įvykti reakcijos, mažinančios susidarančio šlako lydymo temperatūrą (Klinger et al. 2007):

$$
\begin{aligned}
& \mathrm{K}_{2} \mathrm{CO}_{3}+\mathrm{SiO}_{2} \rightarrow \mathrm{K}_{2} \mathrm{O} \cdot \mathrm{SiO}_{2}+\mathrm{CO}_{2} \text { (lydymasis } \sim 1000{ }^{\circ} \mathrm{C} \text { ), } \\
& \mathrm{K}_{2} \mathrm{CO}_{3}+3 \mathrm{Al}_{2} \mathrm{O}_{3} \cdot 2 \mathrm{SiO}_{2} \rightarrow \mathrm{K}_{2} \mathrm{O} \cdot \mathrm{Al}_{2} \mathrm{O}_{3} \cdot \mathrm{SiO}_{2}+\mathrm{CO}_{2} \text { (lydymasis } \sim 850{ }^{\circ} \mathrm{C} \text { ). }
\end{aligned}
$$

Susiformavus šlakams ir stiklui su mažesne lydymosi temperatūra, palyginus su ịrenginio eksploatacijos temperatūra (apie $1000{ }^{\circ} \mathrm{C}$ ), korozijos reakcijos gali intensyviai tęstis net sumažejjus katilo eksploatacijos temperatūrai.

Korozijos produktų susidarymas ugniai atsparioje medžiagoje vyksta su naujadarų tūrio padidèjimu lyginant su pradiniu medžiagų tūriu (Medri et al. 2011). Mokslininkų iš Vokietijos darbe (Schlegel 2008) pateikta šamotinès ir mulitinès medžiagos korozijos produktų tūrio priklausomybè nuo šarminių oksidų koncentracijos medžiagoje (1.6 pav.). Galima pamatyti, kad naujadarų (reakcijos produktų) tūris šamotinèje medžiagoje gali padidèti iki $19 \%$, mulitinejje - iki $22 \%$, kai $\mathrm{K}_{2} \mathrm{O}$ kiekis siekia apie $32 \%$. J. Stjernberg su bendraautoriais (Stjernberg et al. 2013) nustatè, kad didesnio $\mathrm{Al}_{2} \mathrm{O}_{3}$ kiekio aliumosilikatinèje medžiagoje (mulito ir korundo) nustatytas mineralų išsiplètimas, sukèlęs jos irimą, pasiekia 20-25\%. Pastarajame darbe atlikti rentgenografiniai tyrimai parodè, kad medžiagoje susidare šie korozijos produktai: leucitas, kalsilitas ir kaliofilitas (pastarieji du $\mathrm{K}_{2} \mathrm{O} \cdot \mathrm{Al}_{2} \mathrm{O}_{3} \cdot 2 \mathrm{SiO}_{2}$ skirtingos polimorfinès atmainos). 


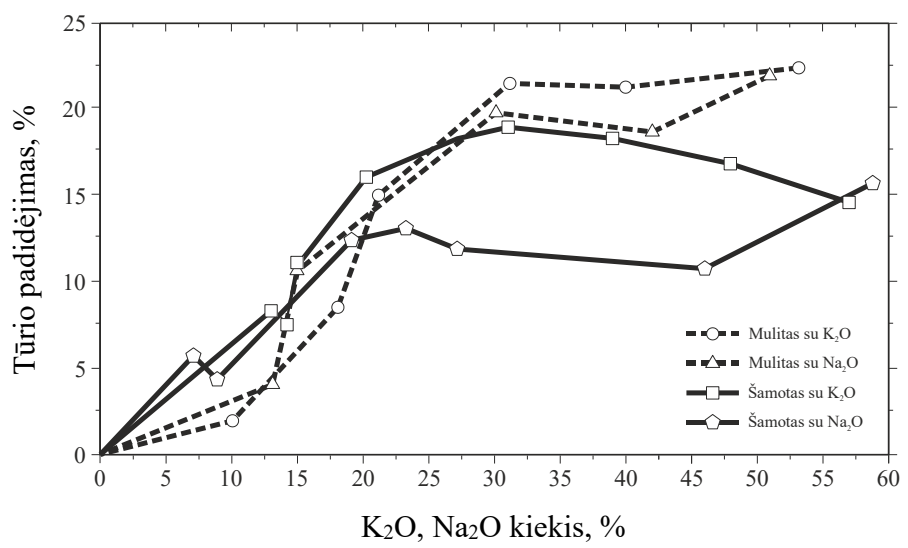

1.6 pav. Mineralų tūrio padidejjimas šarminès korozijos poveikyje aliumosilikatinèse medžiagose (Schlegel 2008)

Fig. 1.6. Increase in mineral volume due to corrosion of aluminosilicates materials (Schlegel 2008)

Dèl mineralų tūrio padidejimo susiformuoja padidinto poringumo ugniai atsparios medžiagos struktūra (Antonovič et al. 2015), vyksta medžiagos irimas.

\subsection{Ugniai atsparaus betono naudojimo kieto biokuro irenginių išklojose ypatumai}

Kieto biokuro ịrenginiuose gali būti naudojamos ugniai atsparios forminès medžiagos (pvz. plytos), taip pat ir neforminès - betonas (Šiaučiūnas et al. 1998). Plytų ar betono, pagaminto iš analogišku aliumosilikatiniu žaliavų, cheminis atsparumas dažniausiai nesiskiria (Soltan et al. 2015: 24). Būtina pastebėti, kad plytos turi tam tikrus trūkumus (konstrukcijų instaliacijai reikia daug laiko, plytų mūras turi daug siūlių, sunku pagaminti sudètingos formos konstrukcinius elementus ir t.t.) (Goberis et al. 2007). Pastebima, jog paskutiniais metais vis plačiau energetinių ịrenginių išklojų pagaminimui naudojami ugniai atsparūs betonai, palengvinantys išklojų įrengimą ir mažinantys jų kainą (Роучка et al. 2010).

Biokuro katiluose gali būti naudojami betonai su ịvairiais rišikliais:

- hidrauliniais, kietejančiais ore;

- keraminiais, kurie sukietejja kaitinimo metu;

- cheminiais, kietejjančiais cheminès reakcijos metu veikiant aplinkos temperatūrai; 
- organiniais, kurie tarpusavyje susiriša esant aplinkos arba aukštesnei temperatūrai.

Daugiausiai paplito ugniai atsparūs betonai su hidrauliniu rišikliu (kalcio aliuminatiniu cementu). Tokių medžiagų matrica (sukietèjęs cementas su ịvairiais smulkiais priedais) yra silpniausia grandis medžiagoje. Ji pasižymi didesniu negu užpildas cheminiu reaktyvumu, turi atviras poras, per kurias lengvai prasiskverbia šarminis lydalas ir dujos sukeldamos medžiagos koroziją. Rišiklio atsparumas korozijai dažniausiai yra mažesnis nei užpildų, nepaisant to, kad žaliavos pasirenkamos pačios geriausios kokybès (Poirier et al. 2008). Tai ypač būdinga ịprastiniams cementiniams betonams. Dèl ekonominių priežasčių juose plačiai naudojami aliumosilikatiniai užpildai - šamotas ir andalūzitas (Кащеев et al. 2007: 560-565).

Boris darbe (Boris 2016) nurodoma, kad rekomenduojami naudojimui kieto kuro įrenginiuose betonai su cirkonio ir chromo užpildais yra dvigubai brangesni (Resende et al. 2001) negu su šamoto ar andalūzito užpildais. Pasibaigus energetinių įrenginių išklojos eksploatavimo laikotarpiui, medžiagos su chromo oksidu (Bennet et al. 2001) utilizuojamos pavojingųjų atliekų sąvartynuose, nes jų perdirbimas yra sudètingas technologinis procesas (Simon et al. 2003; Maruyama et al. 2011).

Iprastiniai ugniai atsparūs šamotiniai betonai su kalcio aliuminatiniu cementu (kurio kiekis betone 15-30\%) ir šiandien neretai naudojami energetikos pramonès šiluminių įrenginių išklojose (tame skaičiuje ir kieto kuro katiluose ir pakurose). Svarbiu tokių betonų privalumu yra jų gamybos paprastumas: betonai gali būti gaminami tiesiog gamybos aikštelèse sumaišant šamotinį užpildą ir cementą. Geri yra ir jų technologiniai veiksniai: lengvas sumaišymas, patogus formavimas, didelis mišinio ,gyvybiškumas“. Taip pat nemažiau svarbus yra aukščiau minètas ekonominis aspektas, nes naudojami nebrangūs cementai, turintys $\mathrm{Al}_{2} \mathrm{O}_{3} \leq 40 \%$, ir šamoto užpildai su $\mathrm{Al}_{2} \mathrm{O}_{3}<30 \%$. Pastebèta, jog tokio betono pagrindinis trūkumas yra jo blogesnès mechaninès charakteristikos (pvz. gniuždymo stipris apie 2 kartus mažesnis) po išdegimo $800-1100{ }^{\circ} \mathrm{C}$, palyginus su betono stipruminemis charakteristikomis po jo pagaminimo. Tai susieta su rišiklio dehidratacijos procesu ir cemento mineralų rekristalizacija aukščiau minètame temperatūros intervale.

Iprastinio ugniai atsparaus betono savybès pagereja modifikuojant jo sudètị ultra dispersinių $\mathrm{SiO}_{2}$ mikrodulkių ir deflokulianto priedais (Goberis et al. 2004; Antonovič et al. 2006; Denisov et al. 2008; Wöhrmeyer et al. 2006). $\mathrm{SiO}_{2}$ mikrodulkès (dalis iš kurių nano dydžio) užpildo tuštumas tarp betono dalelių, dalyvauja kalcio aliuminatinio cemento hidratacijoje ir kietų fazių reakcijose aukštoje temperatūroje (Antonovič et al. 2010 a; Bier et al. 1996; Bjorn et al. 2015). Deflokuliantai mažina vandens poreikị betone, todèl sumažeja pastarojo poringumas, medžiaga pasižymi tankesne struktūra (Antonovič et al. 2006; 
Denisov et al. 2008). Tyrimai parodè, kad modifikuoto iprastinio betono gniuždymo stipris padideja 2-3 kartus palyginus su įprastiniu betonu be aukščiau išvardintų priedų. Ch. Wöhrmeyer (Wöhrmeyer et al. 2006) nurodo, kad pagereja ne tik tokio betono mechaninès savybès, bet ir terminis atsparumas bei atsparumas dilumui. Taip pat prognozuojama, kad tokiuose betonuose gali būti apsunkintas agresyvių dujų ir lydalo prasiskverbimas į medžiagos struktūrą. Nors modifikuoto įprastinio betono šarminio atsparumo tyrimų nebuvo atlikta, galima tikètis ir mažesnio šarminių junginių prasiskverbimo i modifikuotą betono struktūrą.

Šamotbetonio matrica ir savybės žymiai pagerèja mažinant cemento kiekị betono sudètyje ir papildomai naudojant kitus priedus (pvz. ultra dispersini aliuminio oksidą) (Antonovič et al. 2010 b; Deutsche Gesellschaft Feuerfestund Schornsteinbau 2016). Betonuose su sumažintu cemento kiekiu (vidutinio cemento kiekio (VCB), mažacemenčiu (MCB), ypač mažo cemento kiekio (YMCB)) naudojami brangūs ir aukštos kokybès kalcio aliuminatiniai cementai $\left(\mathrm{Al}_{2} \mathrm{O}_{3} \geq 70 \%\right)$ ir priedai (YMCB jų kiekis siekia $\left.40 \%\right)$. Tokiuose betonuose naudojami ir aukštos kokybės šamoto užpildai, kuriuose $\mathrm{Al}_{2} \mathrm{O}_{3}$ kiekis yra $\sim 45 \%$. Dèl aliuminio oksido kiekio padidejjimo šių betonų maksimali panaudojimo temperatūra siekia $\sim 1450{ }^{\circ} \mathrm{C}$ (tradicinių betonų iki $1300^{\circ} \mathrm{C}$ ). Kieto biokuro energetiniuose įrenginiuose su sąlyginai maža eksploatacijos temperatūra dèl ekonominio aspekto šamotiniai betonai su sumažintu cemento kiekiu naudojami retai. Vidutinio cemento kiekio betono sudètyje brangių komponentų naudojama mažiau negu MCB ir YMCB betonuose, todèl ekonominiu aspektu yra perspektyvu ir aktualu pagerinti kaip ịprastinio, taip ir vidutinio cemento kiekio ugniai atsparaus betono fizikines, mechanines savybes ir jų šarmini atsparumą naudojant šamoto užpildą, kuriame $\mathrm{Al}_{2} \mathrm{O}_{3} \leq 35 \%$.

Tobulinant ugniai atsparių betonų savybes, reikia atsižvelgti i rekomendacijas, pateiktas vokiečių tyrèjų (Klinger et al. 2007). Jie nurodo, kad kieto biokuro ịrenginiuose betonų su šamoto užpildais charakteristikos turi atitikti šiems rodikliams: $\mathrm{Fe}_{2} \mathrm{O}_{3}<1 \%$, betono gniuždymo stipris $\geq 60 \mathrm{MPa}$, tankis $\geq 2200 \mathrm{~kg} / \mathrm{m}^{3}$, terminis atsparumas $\geq 30$ ciklų pagal DIN 51068/1.

Reikia pastebėti, kad ugniai atsparių betonų terminiam atsparumui nustatyti nèra universalaus metodo ir ịvairiose šalyse taikomos skirtingos metodikos (Goberis 2003), kurios skiriasi pagal tyrimams naudojamų bandinių dydžius, kaitinimo temperatūrą, bandinių aušinimo būdą (vanduo, oras arba vandeniu šaldomos plokštes). Dažnai rezultatai, gauti skirtingais tyrimų metodais, skiriasi ir tai apsunkina medžiagos parinkimą konkrečioms ịrenginio eksploatacijos sąlygoms. 


\subsection{Ugniai atsparių medžiagų šarminio atsparumo pagerinimo priemonès}

Pastebèta, kad esant tam tikroms medžiagos charakteristikoms (cheminè sudètis, sandara ir kt.), cheminès korozijos greitis ugniai atspariose medžiagose smarkiai sumažèja. Atrodo, kad ugniai atsparios medžiagos praranda savo cheminị reaktyvumą ir tampa sąlyginai inertinès. To priežastys - apsauginio sluoksnio (barjero) formavimasis medžiagoje. Pvz., tai stebima, kai ugniai atspari medžiaga su silicio karbidu (SiC) oksiduojasi. SiC užpildo paviršiuje susidaro silicio didoksidas, kuris reaguoja su šarminiais junginiais ir formuojasi klampaus stiklo apsauginis sluoksnis (Jacobson et al. 1998; Lou et al. 1990).

Panašus reiškinys pastebètas naudojant specialios sudèties $\mathrm{Al}_{2} \mathrm{O}_{3}-\mathrm{SiC}$ medžiagą aukštakrosnès išklojoje, kurioje, veikiant kalcio silikatiniam šlakui, medžiagoje formuojasi $\alpha$ ir $\beta-\mathrm{SiC}$, vèliau susidaro ir apsauginis klampaus stiklo sluoksnis (Пономаренко et al. 2019).

Kitas pavyzdys, susijęs su špinelio formavimuisi aliuminio - magneziniame betone. Šiuo atveju reakcijos su šlakų, susidedančių iš kalcio, aliuminio ir geležies oksidų, aplink aliuminio oksido užpildą susidaro naujos kalcio aliuminatinès fazès $\left(\mathrm{CaAl}_{12} \mathrm{O}_{19}\right.$ ir $\left.\mathrm{CaAl}_{4} \mathrm{O}_{7}\right)$. Tokių reakcijos produktų sluoksnis stabdo betono koroziją (Poirier et al. 2017).

E. Alibasic atlikti tyrimai rodo (Alibasic et al. 2014), kad norint padidinti aliumosilikatinių betonų atsparumą šarminei korozijai, sudètyje naudojamas kvarco priedas. R. Boris darbe nustatyta (Boris 2016), kad veikiant betoną, turintị malto kvarcinio smèlio priedo, šarmine druska $\left(\mathrm{K}_{2} \mathrm{CO}_{3}\right)$, veikimo paviršiuje formuojasi apsauginis sluoksnis, stabdantis šarminių junginių skverbimąsi ị betono su kalcio aliuminatiniu užpildu struktūrą. Priklausomai nuo šio priedo kiekio $(2,5 \%$ ir $5 \%$ ) betono atsparumas šarminio lydalo poveikiui padideja nuo 3 (be priedo) iki 6-8 ciklų (su priedu). Šio autoriaus darbuose aprašoma, kad betone su kalcio aliuminatiniu užpildu, susidarant apsauginiam sluoksniui, nėra pakankamai ištirtos jo susidarymo sąlygos, charakteristikos ir jo stabilumas veikiant eksploatacinėms apkrovoms (pvz. terminiams smūgiams). Sukurtas betonas (Boris 2016) turi labai mažą terminị atsparumą ( 8 ciklai) ir biokuro katilų išklojoms jo panaudojimas yra ribotas (gali būti naudojamas tik atskiru konstrukcinių mazgu pagaminimui, pvz. tokių, kaip kuro padavimo zonos iškloja). Taip pat reikia pažymèti, kad kvarcinio smèlio priedas gali neigiamai įtakoti kai kurias svarbias medžiagos savybes. Žinoma, kad aukštose temperatūrose vyksta kvarco polimorfiniai kitimai su mineralo tūrio didejjimu: $573{ }^{\circ} \mathrm{C}$ temperatūroje, $\beta \leftrightarrow \alpha-k$ varcas, $0,8-1,3 \% ; 1250{ }^{\circ} \mathrm{C}$ temperatūroje $\alpha-$ kvarcas $\rightarrow \alpha$-kristobalitas, 17,4 \% (Brunk 2001; Goswami et al. 2015). Todèl, projektuojant naują ugniai atsparaus betono sudètị ir naudojant kvarco priedą, jo ir kitų betono komponentų kiekis turi būti kruopščiai parinktas atsižvelgiant ị 
betono savybes - termini atsparumą, stiprumo savybes $600-1250{ }^{\circ} \mathrm{C}$ temperatūros intervale, kurios gali būti neigiamai paveiktos $\mathrm{SiO}_{2}$ polimorfiniu kitimų.

Kita medžiagų šarminio atsparumo padidinimo priemonè - pagerinti betono matricos savybes naudojant mikro ir nano dydžio priedus. Pavyzdžiui, cirkonio silikato priedas $\left(\mathrm{ZrSiO}_{4}\right)$ matricoje su mulitu leidžia pagerinti ne tik mechanines mulitinès medžiagos charakteristikas, bet jos atsparumą cheminei korozijai (Baspinar et al. 2009). Pagrindinè medžiagos savybių pagerinimo priežastis yra priedo poveikis, sukeliantis medžiagos struktūros sutankejjimą. B. Ren darbuose parodyta, (Ren et al. 2015 a; Ren et al. 2015 b) kad naudojant ịvairius priedus, boksito - SiC ugniai atsparios medžiagos šarminès korozijos atsparumas padidejja mažèjant tokios medžiagos porų dydžiams. Tokiu būdu apsunkinamas agresyvių dujų prasiskverbimas ị medžiagos matricą. K. Butzbach nurodo (Butzbach 2019), kad optimizuojant medžiagos komponentų dalelių pasiskirstymą, galima pasiekti ypač mažą aliumosilikatinio ugniai atsparaus betono atvirą poringumą (10-12\%) ir gerą šios medžiagos atsparumą šarminei korozijai.

Matricos cheminès sudèties koregavimas gali būti veiksminga priemonè tam, kad būtų gauti susiformuojančių šarminių korozijos produktų tūrio pokyčiai. Tokiais veiksmais siekiama padidinti reakcijų laipsnị stiklo fazejje mažinant kalio aliumosilikatinių fazių formavimąsi (kartu mažès neigiamas mineralų tūrio kitimas) (Ren et al. 2015 a). Autorius taip pat nurodo, kad papildomų stiklo fazių formavimasis medžiagoje gali blokuoti atviras poras ir tai apsaugos nuo tolimesnio šarminių dujų prasiskverbimo ị medžiagos struktūrą. Toks pageidaujamas šarminių junginių poveikio mechanizmas ir pastebimas silicio oksido praturtintoje medžiagos matricoje.

Medžiagų atsparumą cheminei korozijai padidinti leidžia impregnavimo technologija. Tam naudojamos ịvairių medžiagų suspensijos (Kobayashi 2003 United States Patent US 6,667,074 B2; Slovikovskii et al. 2016) ir rišikliai (Khlystov et al. 2017), kai stengiamasi sumažinti medžiagos poringumą. Tačiau, naudojamų impregnavimui medžiagų vaidmuo gali būti ir kitas. Darbe (Fard et al. 2014) nustatyta, kad impregnavimas nano $-\mathrm{Cr}_{2} \mathrm{O}_{3}$ ir nano $-\mathrm{Fe}_{2} \mathrm{O}_{3}$ dalelių suspensijomis žymiai pagerino chromo - magnezinès medžiagos atsparumą korozijai. Nano dalelès, esančios medžiagos porose, tirpsta veikiant šlako lydalui ir padidina jo klampi. Tokiu būdu mažinamas šlako lydalo skverbimosi potencialas. Panašūs darbai atlikti impregnuojant aliuminio oksido ugniai atsparią medžiagą retujų žemių oksidų (REO) suspensijomis (JAV energetikos departamento ataskaita, 1999). Šiuo atveju ryškaus efekto medžiagos korozijai nepastebèta.

Kai kurios žaliavos taip pat gali būti naudojamos aliumosilikatinių medžiagu šarminio atsparumo padidinimui. Nustatyta, kad kalcio heksa 
aliuminatas (hibonitas, $\mathrm{CaO} \cdot 6 \mathrm{Al}_{2} \mathrm{O}_{3}$ ) yra perspektyvi medžiaga ir gali būti panaudojama šarminio poveikio sąlygomis (Schnabel et al. 2011; Loison et al. 2017). Tyrimai parodè (Büchel et al. 2005), kad kalio heksa aliuminatas reaguoja su kaliu susidarant $\beta$ - aliuminio oksidui. Pastarojo mineralo tankis yra analogiškas kalcio heksa aliuminato tankiui. Tai reiškia, kad susidarius tokiam naujadarui nèra neigiamo mineralų tūrio išsiplètimo ir nesivystys medžiagos destrukcijos procesas. Darbe (Prigent et al. 2011) nurodoma, kad andalūzitas pasižymi labai geru atsparumu natrio dujoms. Tai paaiškinama mulito kristalų kompozito kapiliarinio tinklo užpildymu stiklo faze. Tokios medžiagos atsparumas natrio dujoms yra prilygintas lydytam mulitui.

\subsection{Pirmojo skyriaus išvados ir disertacijos uždavinių formulavimas}

1. Literatūros apžvalga parodè, kad aliumosilikatinès, tame tarpe ir šamotinès medžiagos nèra atsparios šarminei korozijai aukštoje temperatūroje.

2. Kieto biokuro energetiniuose šilumos irenginiuose naudojant šamotines medžiagas dažnai staiga suyra išklojos. Tai ịvyksta, kai lokalinès temperatūros ịrenginyje viršija eksploatacinę $1100{ }^{\circ} \mathrm{C}$ temperatūrą ir pasiekiama pelenų lydymosi temperatūra.

3. Didinant šamotinių ir kitų aliumosilikatinių betonų atsparumą šarminei korozijai, gali būti naudojamos ịvairios priemonės: atsparių šarminei korozijai aliumosilikatinių žaliavų naudojimas, impregnavimo technologijos taikymas, priedų, mažinančių medžiagos poringumą ir porų dydžius, kaip ir priedų, skatinančių apsauginio barjero formavimąsi, bei kito poveikio priedų naudojimas.

4. Maltas kvarcinis smèlis priklauso priedų grupei, kurios gali ịtakoti atsparaus šarminei korozijai barjero formavimąsi medžiagos paviršiuje ir stabdo šarminių junginių skverbimąsi ị aliumosilikatinès medžiagos struktūrą. Pastebima, jog neaiškus tokio priedo poveikis aliumosilikatinių betonų eksploatacinėms savybėms (ypač terminiam atsparumui), neaiškūs barjero formavimosi parametrai, nežinomos jo savybés ir stabilumas veikiant eksploatacijos apkrovoms (aukšta temperatūra, terminiai smūgiai). Taip pat nèra aišku, kaip keisis atsparumas šarminei korozijai naudojant iprastiniame ir vidutinio cemento kiekio betone skirtingos cheminès sudèties šamoto užpildus, 
kuriuose yra skirtingi $\mathrm{SiO}_{2}$ ir $\mathrm{Al}_{2} \mathrm{O}_{3}$ kiekiai, ir naudojant betono matricoje ultradispersinius $\mathrm{SiO}_{2}$ ir $\mathrm{Al}_{2} \mathrm{O}_{3}$ priedus.

Atsižvelgiant ì literatūros analizès išvadas, darbo tikslui pasiekti buvo suformuluoti šie uždaviniai:

1. Ivertinti skirtingo $\mathrm{Al}_{2} \mathrm{O}_{3} / \mathrm{SiO}_{2}$ santykio $(0,44 ; 0,68 ; 0,89)$ šamoto užpildų šarminį atsparumą $1100-1200{ }^{\circ} \mathrm{C}$ temperatūrose.

2. Nustatyti iprastinio ir vidutinio cemento kiekio ugniai atsparaus šamotinio betono, su skirtingo $\mathrm{Al}_{2} \mathrm{O}_{3} / \mathrm{SiO}_{2}$ santykio šamoto užpildu bei kvarcinio smèlio priedu, fizikines, mechanines ir termines savybes.

3. Ištirti ịprastinio ir vidutinio cemento kiekio ugniai atsparių betonų su kvarcinio smèlio priedu šarminị atsparumą $1100-1200{ }^{\circ} \mathrm{C}$ temperatūroje ir nustatyti apsauginio barjero, stabdančio šarminę koroziją, formavimosi ypatumus. 


\section{2}

\section{Naudotos medžiagos ir ugniai atsparių betonų tyrimo metodai}

Skyriuje aprašomos darbe naudotos medžiagos ir jų savybès bei taikyti tyrimo metodai.

Ši medžiaga paskelbta dviejuose autoriaus (su bendraautoriais) straipsniuose (Zdanevičius et at. 2018; Antonovič et al. 2019).

\subsection{Tyrimams naudotos medžiagos}

Ugniai atsparaus rišiklio komponentai:

$\checkmark$ Kalcio aliuminatinis cementas (AC40) -,ISTRA 40“ markès, pagamintas imoneje „Calucem $\mathrm{GmbH}^{\circ}$ (Vokietija). Cheminè sudètis (masès \%): $\mathrm{Al}_{2} \mathrm{O}_{3}$ - 40,0; $\mathrm{CaO}$ - 39,0; $\mathrm{Fe}_{2} \mathrm{O}_{3}-15,0 ; \mathrm{SiO}_{2}-4,5 ; \mathrm{MgO}-1,2$. Pagrindiniai mineralai: $\mathrm{CA}$, papildomos fazès $\mathrm{C}_{4} \mathrm{AF}, \mathrm{C}_{2} \mathrm{AS}, \mathrm{C}_{12} \mathrm{~A}_{7}$. Atsparumas ugniai $\sim 1270{ }^{\circ} \mathrm{C} ; \mathrm{S}_{\text {pav. }}=295 \mathrm{~m}^{2} / \mathrm{kg}$.

$\checkmark$ Kalcio aliuminatinis cementas (AC70)-, Gorkal 70“ markès, pagamintas įmonëje „Górkal Cement“ (Lenkija). Cheminè sudètis (masès \%): $\mathrm{Al}_{2} \mathrm{O}_{3}$ - 71,0; $\mathrm{CaO}$ - 28,0; $\mathrm{SiO}_{2}-0,5 ; \mathrm{Fe}_{2} \mathrm{O}_{3}-0,4$. Pagrindiniai mineralai: $\mathrm{CA}$ ir $\mathrm{CA}_{2}$, papildomos fazès $\mathrm{C}_{12} \mathrm{~A}_{7}$ ir $\alpha-\mathrm{Al}_{2} \mathrm{O}_{3}$. Atsparumas ugniai $\sim 1630{ }^{\circ} \mathrm{C}$; $\mathrm{S}_{\mathrm{pav} .}=450 \mathrm{~m}^{2} / \mathrm{kg}$. 
$\mathrm{SiO}_{2}$ mikrodulkès - „RW-Fuller“ markès, pagamintos imonèje „RW

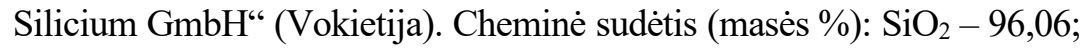
$\mathrm{Al}_{2} \mathrm{O}_{3}-0,20 ; \mathrm{Fe}_{2} \mathrm{O}_{3}-0,05 ; \mathrm{C}-0,60 ; \mathrm{CaO}-0,25 ; \mathrm{MgO}-0,40 ; \mathrm{K}_{2} \mathrm{O}-$ 1,$20 ; \mathrm{Na}_{2} \mathrm{O}-0,10 ; \mathrm{SO}_{3}-0,35$. $\mathrm{S}_{\mathrm{pav} .}=18000-22000 \mathrm{~m}^{2} / \mathrm{kg}$.

$\checkmark$ Reaktyvusis aliuminio oksidas - CTC 20 markès, pagamintas įmonèje „Almatis“(Vokietija). Cheminè sudètis (masès \%): $\mathrm{Al}_{2} \mathrm{O}_{3}-99,70 ; \mathrm{Na}_{2} \mathrm{O}$ $-0,12 ; \mathrm{Fe}_{2} \mathrm{O}_{3}-0,03 ; \mathrm{SiO}_{2}-0,03 ; \mathrm{CaO}-0,02 . \mathrm{S}_{\text {pav. }}=2100 \mathrm{~m}^{2} / \mathrm{kg}$.

$\checkmark$ Degtas aliuminio oksidas-CT 19 markès, pagamintas ịmoneje ,Almatis“ (Vokietija). Cheminè sudetis (masès \%): $\mathrm{Al}_{2} \mathrm{O}_{3}-99,80 ; \mathrm{Na}_{2} \mathrm{O}-0,08$; $\mathrm{Fe}_{2} \mathrm{O}_{3}-0,02 ; \mathrm{SiO}_{2}-0,01 ; \mathrm{CaO}-0,03$. $\mathrm{S}_{\text {pav. }}=400 \mathrm{~m}^{2} / \mathrm{kg}$.

$\checkmark$ Maltas šamotas, paruoštas iš BOS 125, BOS 135 ir BOS 145 markès šamotu (įmonè „Tabex-Ozmo“, Lenkija), malant 1 valandą rutuliniame malūne ir persijojant per sietus, kurių akučių dydis $0,14 \mathrm{~mm}$. Nustatytas BOS $125-\mathrm{S}_{\mathrm{pav}}=388 \mathrm{~m}^{2} / \mathrm{kg}$, BOS $135-\mathrm{S}_{\mathrm{pav} .}=409 \mathrm{~m}^{2} / \mathrm{kg}$, BOS $145-$ $\mathrm{S}_{\text {pav. }}=395 \mathrm{~m}^{2} / \mathrm{kg}$. Cheminè MŠ sudètis yra analogiška atitinkamos rūšies šamoto užpildui (žiūrèti šamoto užpildas).

$\checkmark$ Maltas kvarcinis smèlis (MKS) - pagamintas ịmonèje AB ,Anykščiu kvarcas“ (Lietuva). Cheminè sudètis (masès \%): $\mathrm{SiO}_{2}-99,20 ; \mathrm{Fe}_{2} \mathrm{O}_{3}-$ 0,$05 ; \mathrm{Al}_{2} \mathrm{O}_{3}-0,60 ; \mathrm{TiO}_{2}-0,10 . \mathrm{S}_{\text {pav. }}=490 \mathrm{~m}^{2} / \mathrm{kg}$, granuliometrinè sudètis pateikta 2.1 paveiksle.

$\checkmark$ Vanduo-geriamasis.

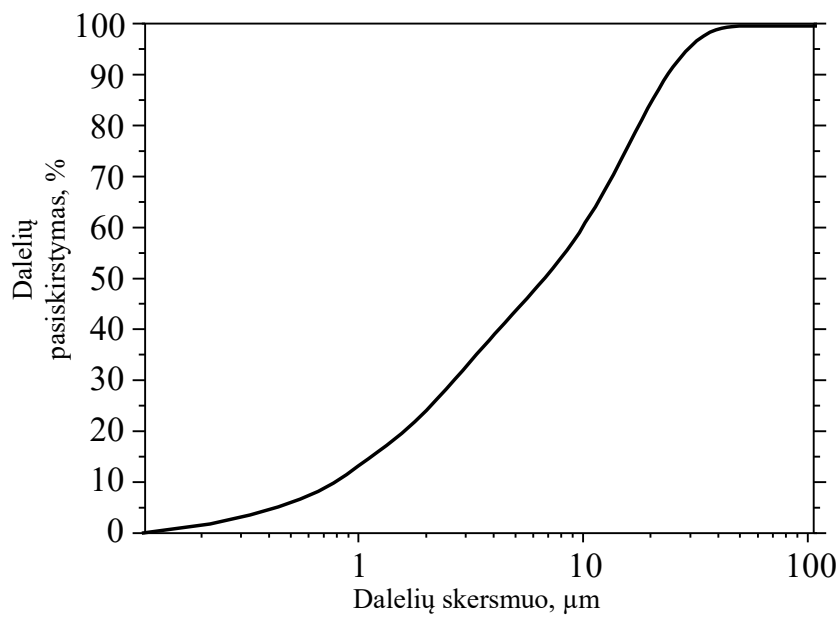

2.1 pav. Malto kvarcinio smèlio dalelių skersmens priklausomybè nuo jų pasiskirstymo

Fig. 2.1. Dependence of the diameter of ground quartz sand particles on their distribution 
Cheminiai priedai:

$\checkmark$ Castament FS20 (FS20) - polikarboksilatinių esterių (PCE) pagrindo deflokuliantas, pagamintas įmoneje „BASF Construction Solutions $\mathrm{GmbH}^{\prime}$ (Vokietija), $\mathrm{pH}=4,6$.

$\checkmark$ Castament FS30 (FS30) - polikarboksilatinių esterių (PCE) pagrindo deflokuliantas, pagamintas imoneje „BASF Construction Solutions $\mathrm{GmbH}^{\prime}$ (Vokietija), $\mathrm{pH}=8,5$.

$\checkmark$ Natrio tripolifosfatas (techninis) (NT) - bevandenis $\mathrm{Na}_{5} \mathrm{P}_{3} \mathrm{O}_{10}$, $\mathrm{pH}=9,3$.

Užpildai:

$\checkmark$ Šamoto BOS 125, BOS 135 ir BOS 145 markès - gaminami įmonejje „Tabex-Ozmo“ (Lenkija). Jų charakteristikos pateiktos 2.2 lentelèje. $\mathrm{Al}_{2} \mathrm{O}_{3} / \mathrm{SiO}_{2}$ santykis BOS 125 yra 0,44; BOS 135 yra 0,68; BOS 145 yra 0,89 .

Metalinis pluoštas (fibra)

$\checkmark$ C-MIX 25-0.4-304 banguotas pluoštas, pagamintas iš AISI 304 markès nerūdijančio plieno vielos įmonèje "SILICON USA Inc“. Pluošto skersmuo $-0,4 \mathrm{~mm}$, ilgis $-25 \mathrm{~mm}$.

Cheminis reagentas

$\checkmark \mathrm{K}_{2} \mathrm{CO}_{3}-99,0 \%$, pagamintas įmoneje ,Sigma Aldrich“(JAV).

2.1 lentelè. Šamoto užpildo cheminė sudètis, piltinis tankis ir atsparumas ugniai

Table 2.1. Chemical composition, bulk density and refractoriness of fireclay aggregate

\begin{tabular}{|c|c|c|c|}
\hline \multirow{2}{*}{ Charakteristika } & \multicolumn{3}{|c|}{ Šamoto užpildas } \\
\cline { 2 - 4 } & BOS 125 & BOS 135 & BOS 145 \\
\hline Cheminė sudètis, \%: & 26,31 & 36,60 & 44,30 \\
$\mathrm{Al}_{2} \mathrm{O}_{3}$ & 59,18 & 53,70 & 49,50 \\
$\mathrm{SiO}_{2}$ & 2,91 & 3,33 & 2,07 \\
$\mathrm{Fe}_{2} \mathrm{O}_{3}$ & 2,05 & 3,05 & 0,60 \\
$\mathrm{CaO}$ & 0,88 & 0,74 & 0,92 \\
$\mathrm{MgO}$ & 0,88 & 1,30 & 1,35 \\
$\mathrm{TiO}$ & 0,70 & 0,97 & 0,73 \\
$\mathrm{~K}_{2} \mathrm{O}$ & 7,09 & 0,31 & 0,53 \\
$\mathrm{Kiti}$ & 1350 & 1430 & 1510 \\
\hline Piltinis tankis, kg/m & 1690 & 1710 & 1750 \\
\hline Atsparumas ugniai, ${ }^{\circ} \mathrm{C}$ & \multicolumn{3}{|}{} \\
\hline
\end{tabular}


Šamotų užpildų frakcijų cheminè sudètis ir piltinis tankis buvo nustatytas šiame darbe, atsparumas ugniai pateiktas iš gamintojo medžiagos duomenų lapo. Užpildų granuliometrinė sudètis pateikta 2.2 paveiksle.

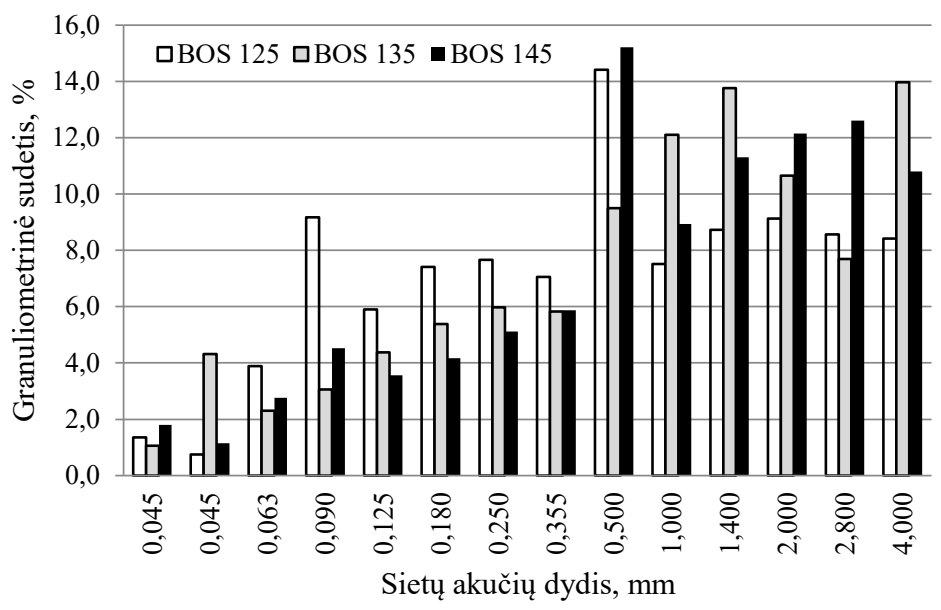

2.2 pav. Šamoto užpildo granuliometrinè sudètis

Fig. 2.2. Particle size distribution of fireclay aggregate

\subsection{Darbe tiriami betonai ir taikyti metodai}

Tiriamų ugniai atsparių betonų sudètys pateiktos 2.2-2.3 lentelèse.

Betonų destrukcijos tyrimuose (3.2.3 poskyris), naudojamas komercinis, mažą cemento kieki turintis, šamotinis ugniai atsparus betonas šios sudeties: $\mathrm{Al}_{2} \mathrm{O}_{3}-51,0 \%, \mathrm{SiO}_{2}-44,0 \%, \mathrm{CaO}-1,6 \%$ (betono žymuo MCB). Betono pagaminimui panaudotas vandens kiekis sieke 5,5\%. Taip pat buvo panaudoti VCB3 ir VCB4 betonai su papildomu $1 \%$ metalinio pluošto priedu (žymuo VCB3-F ir VCB4-F). Vandens kiekis pastaruosiuose nepasikeite lyginant su betonais be pluošto (2.3 lentelè).

Betono mišinių paruošimo technologija pateikta 2.3 paveiksle.

Kalcio aliuminatinio cemento, malto šamoto ir malto kvarcinio smèlio savitasis paviršius nustatytas Blaino prietaisu, laikantis LST EN 196-6:1996 standarto reikalavimų.

Užpildo granuliometrinè sudètis nustatyta, naudojant „Haver EML 200“ skaitmeninę sietų purtyklę, sietų komplekto akučių dydžiai, mm: 4,000;2,800; 2,$000 ; 1,400 ; 1,000 ; 0,500 ; 0,355 ; 0,250 ; 0,140 ; 0,180 ; 0,125 ; 0,090 ; 0,063 ; 0,045$; $<0,045$. 
2.2 lentelė. Iprastinio betono sudètys (masès, \%)

Table 2.2. Compositions of conventional castable (mass, \%)

\begin{tabular}{|c|c|c|c|c|c|c|}
\hline \multirow{2}{*}{ Komponentai } & \multicolumn{7}{|c|}{ Betono sudèties žymuo } \\
\cline { 2 - 7 } & B2 & B3 & B4 & BQ2 & BQ3 & BQ4 \\
\hline AC40 & 25 & 25 & 25 & 25 & 25 & 25 \\
\hline SiO2 mikrodulkès $_{2,5}$ & 2,5 & 2,5 & 2,5 & 2,5 & 2,5 \\
\hline Maltas kvarcinis smėlis & - & - & - & 2,5 & 2,5 & 2,5 \\
\hline Deflokuliantas FS 30* & 0,1 & 0,1 & 0,1 & 0,1 & 0,1 & 0,1 \\
\hline Maltas šamotas: & & & & & & \\
BOS 125 & 12,5 & - & - & 10 & - & - \\
BOS 135 & - & 12,5 & - & - & 10 & - \\
BOS 145 & - & - & 12,5 & - & - & 10 \\
\hline Šamoto užpildas: & & & & & & \\
BOS 125 & 60 & - & - & 60 & - & - \\
BOS 135 & - & 60 & - & - & 60 & - \\
BOS 145 & - & - & 60 & - & - & 60 \\
\hline Vanduo* & 10,4 & 10,4 & 8,5 & 10 & 10 & 8,5 \\
\hline
\end{tabular}

Pastaba: ${ }^{*}$ - virš $100 \%$ sausos masès.

2.3 lentelè. Vidutinio cemento kiekio betono sudètys (masès, \%)

Table 2.3. Compositions of medium cement castable (mass, \%)

\begin{tabular}{|c|c|c|c|c|c|}
\hline \multirow{2}{*}{ Komponentai } & \multicolumn{5}{|c|}{ Betono sudèties žymuo } \\
\cline { 2 - 6 } & VCB2 & VCB3 & VCB4 & VCB3-F & VCB4-F \\
\hline AC70 & 12 & 12 & 12 & 12 & 12 \\
\hline SiO 2 mikrodulkès $^{*}$ & 5 & 5 & 5 & 5 & 5 \\
\hline Reaktyvusis aliuminio oksidas & 5 & 5 & 5 & 5 & 5 \\
\hline Degtas aliuminio oksidas & 7 & 7 & 7 & 7 & 7 \\
\hline Maltas kvarcinis smèlis & 2,5 & 2,5 & 2,5 & 2,5 & 2,5 \\
\hline Deflokuliantas FS 20* & 0,1 & 0,1 & 0,1 & 0,1 & 0,1 \\
\hline Natrio tripolifosfatas* & 0,1 & 0,1 & 0,1 & 0,1 & 0,1 \\
\hline Maltas šamotas: & & & & & \\
BOS 125 & 8 & - & - & - & - \\
BOS 135 & - & 8 & - & 8 & - \\
BOS 145 & - & - & 8 & - & 8 \\
\hline Šamoto užpildas: & & & & & \\
BOS 125 & 60,5 & - & - & - & - \\
BOS 135 & - & 60,5 & - & 60,5 & - \\
BOS 145 & - & - & 60,5 & - & 60,5 \\
\hline Metalinis pluoštas* & - & - & - & 1 & 1 \\
\hline Vanduo* & 9 & 9 & 8 & 9 & 8 \\
\hline
\end{tabular}

Pastaba: * - virš $100 \%$ sausos masès. 


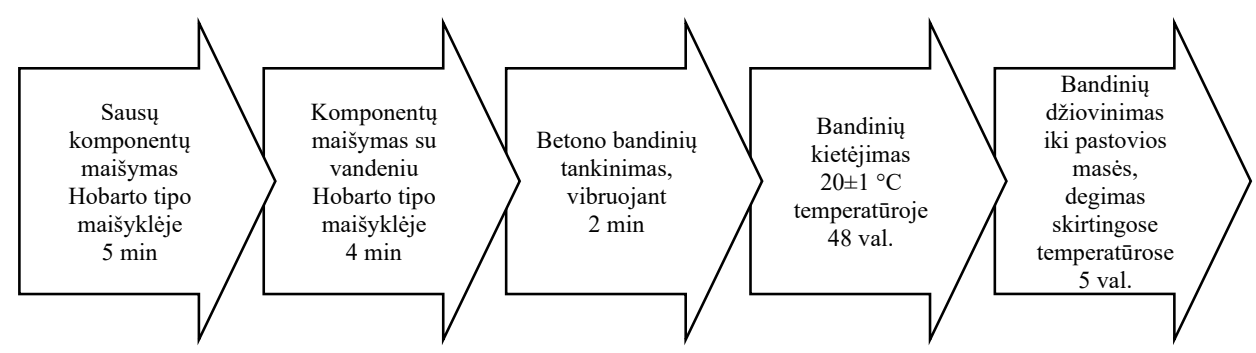

2.3 pav. Ugniai atsparaus betono bandinių pagaminimo technologijos schema

Fig. 2.3. Technology scheme of production of refractory castable specimens

Pagrindinès betonų fizikinès ir mechaninès charakteristikos nustatytos pagal LST EN ISO 1927-6:2013 standartą. Betono bandinių tankis, gniuždymo stipris, ultragarso impulso sklidimo trukmè nustatyta betono $70 \times 70 \times 70 \mathrm{~mm}$ bandiniams po 48 val. kietèjimo, džiovinimo $110{ }^{\circ} \mathrm{C}$ temperatūroje, degimo $1100{ }^{\circ} \mathrm{C}$ bei $1200{ }^{\circ} \mathrm{C}$ temperatūrose. Gniuždymo stipris nustatytas hidrauliniu presu „ALPHA3-3000S“, kurio maksimali bandymo apkrova - $3000 \mathrm{kN}$, tikslumas pagal DIN EN ISO7500-1 - 1 klasè.

Ultragarso impulso sklidimo laikas nustatytas prietaisu „Pundit 7“ (keitikliu dažnis $54 \mathrm{kHz})$ ir apskaičiuotas ultragarso impulso sklidimo greitis $\left(\mathrm{V}_{\mathrm{UI}}, \mathrm{m} / \mathrm{s}\right)$ pagal formulę:

$$
V_{U I}=\frac{l}{\tau},
$$

čia: $l$ - bandinio ilgis, $\mathrm{m} ; \tau$ - signalo sklidimo laikas, $\mathrm{s}$.

Betono tamprumo modulis (E, GPa) apskaičiuotas pagal formulę:

$$
E=V^{2} \cdot \gamma\left[\frac{(1+\mu) \cdot(1-2 \mu)}{1-\mu}\right],
$$

čia: $V$ - ultragarso impulso sklidimo greitis, $\mathrm{m} / \mathrm{s}, \gamma$ - betono tankis, $\mathrm{kg} / \mathrm{m}^{3}$, $\mu$ - Puasono koeficientas VCB3, VCB3-F, VCB4, VCB4-F ir MCB markès betonams buvo priimtas vienodas - 0,17 (Niyogi et al. 1994).

Betonų šiluminio pletimosi koeficientas nustatytas naudojant Linseis L76 (Linseis Messgeraete $\mathrm{GmbH}$, Vokietyja) dilatometrą.

Betono bandinių deformacija nustatyta pagal LST EN ISO 1927-6:2013 standartą elektroniniu slankmačiu „OPD150“ 0,01mm tikslumu.

Betono atvirasis poringumas nustatytas pagal LST EN ISO 10545-3:2000 standartą su vakuumavimo prietaisu, kuris palaiko $(100 \pm 1) \mathrm{kPa}$ vakuumą $30 \mathrm{~min}$. 
Betono šarminiu junginių poveikio atsparumui ịvertinimui pasirinktas tiglio metodas (ASTM C 454-83:2007). Bandymui šiuo metodu pagaminti 70×70×70 mm betono bandiniai su cilindro formos ertme, kurios skersmuo $20 \mathrm{~mm}$, aukštis $30 \mathrm{~mm}$ (po 4 bandinius vienai betono sudèčiai). Bandiniai išdžiovinti $110{ }^{\circ} \mathrm{C}$ temperatūroje ir išdegti $1100^{\circ} \mathrm{C}$ ir $1200{ }^{\circ} \mathrm{C}$ temperatūrose. İ cilindro formos ertmę ipilta $9 \mathrm{~g} \mathrm{~K}_{2} \mathrm{CO}_{3}$. Ertmè uždengta tos pačios sudèties betono plokštele ir bandiniai kaitinami 5 valandas $1100{ }^{\circ} \mathrm{C}$ arba $1200{ }^{\circ} \mathrm{C}$ temperatūrose. Po daugkartinių testų (kiekvieną kartą iš naujo ịpilta $9 \mathrm{~g} \mathrm{~K}_{2} \mathrm{CO}_{3}$ ) bandiniai vizualiai apžiūrimi fiksuojant mikroịtrūkių atsiradimą. Dalis bandinių perpjauta per cilindro formos aši i dvi dalis ir tiriamos šarminès medžiagos paveiktos betono zonos.

Betono terminis atsparumas nustatytas remiantis GOST 20910-2019. $70 \times 70 \times 70 \mathrm{~mm}$ bandiniai po suformavimo kondicionuojami $\left(20 \pm 1{ }^{\circ} \mathrm{C}\right.$, santykinis oro drègnis $90-100 \%$ ) vèliau vizualiai apžiūrimi ir pasveriami (mèginiai su įtrūkiais atmetami). Betonų bandiniai sudedami i krosnị, kuri ịkaitinama iki $950{ }^{\circ} \mathrm{C}$ ir išlaikomi šioje temperatūroje $40 \mathrm{~min}$. Po 40 minučių bandiniai išimami iš krosnies ir atvėsinami panardinant juos ị vonią su kambario temperatūros vandeniu ir išlaikomi $5 \mathrm{~min}$. Toliau bandiniai išraukiami iš vandens ir 10 minučių laikomi kambario $(20 \pm 5){ }^{\circ} \mathrm{C}$ temperatūroje. Tada ciklinis kaitinimas ir vèsinimas kartojamas. Kiekvienas kaitinimas ir aušinimas vandenyje ir ore yra terminis ciklas. Po kiekvieno terminio ciklo bandiniai apžiūrimi ir ịvertinama bei fiksuojama ịtrūkimų išvaizda, suirimo pobūdis (bandinių įtrūkimai, suirimai) ir nustatomas masės nuostolis. Atskilę gabalai ir atvèsę bei nukritę vandenyje ir tie, kurie atsiskiria lengvu pirštų paspaudimu įskaitomi ir užfiksuojami kaip suirimai.

Terminių ciklų skaičius iki betonų suirimo ar praradimo daugiau nei $20 \%$ pradinès masès yra priimamas kaip terminio atsparumo rodiklis, kuri pasiekus bandymas nutraukiamas. Iš nustatytų terminių ciklų skaičiaus ugniai atsparaus betono rodiklis paskaičiuojamas kaip aritmetinis vidurkis.

Maksimali panaudojimo temperatūra nustatyta pagal PN-EN ISO 1893:2009 standartą (EN ISO 1893:2009).

Medžiagos cheminè sudètis nustatyta naudojant rentgeno fluorescencijos (XRF-WD) metodą. Tam buvo naudojamas ZSX Primus IV spektrometras (Rigaku Corp., Japonija), turintis Rh vamzdelị, kurio anodo ịtampa $4 \mathrm{kV}$. Tyrimui atlikti paruoštos $37 \mathrm{~mm}$ skersmens tabletès, suspaustos $200 \mathrm{kN}$ jëga.

Medžiagu kokybinès fazinès sudėties analizè atlikta „DRON-7“ (Rusija) rentgeno difraktometru. Rentgeno spinduliuotès $\mathrm{Cu} \mathrm{K \alpha}$ spektrui $(\lambda=0,1541837 \mathrm{~nm})$ gauti naudotas grafito monochromatorius. Bandymu parametrai: $30 \mathrm{kV}$ ịtampa; $12 \mathrm{~mA}$ srove; difrakcijos kampo $2 \theta$ intervalas nuo $5^{\circ}$ iki $60^{\circ}$, detektoriaus judejjimo žingsnis $-0,02^{\circ}$; intensyvumo matavimo trukmé žingsnyje - 0,5 s. Fazių identifikavimas atliktas dešifruojant rentgenogramas su PDF-2 (2003) ir ICDD difrakcijos duomenu bazių programine ịranga. 
Kiekybiniai mineralų pokyčiai rentgenogramose vertinami pagal mineralo pagrindinio difrakcinio maksimumo smailès aukštį.

Rentgenografinių tyrimų rezultatų apdorojimas buvo vykdomas su „Match!“ programa pagal Rietveld metodą (Putz et al. 2020). Kristalinei fazei nustatyti XRD prietaise buvo pasirinktas bazinis fonas (Backgound), o amorfinei fazei nustatyti buvo pasirinktas papildomas prietaiso fonas. Bazinis fonas buvo pasirinktas panaudojant logoritminį algoritmą. Papildomas prietaiso fonas buvo realizuotas maksimaliai nuleidus bazinio fono kreivę. Amorfinès (stikliškosios) fazès ịvertinimui pasirinktas difrakcijos kampo intervalas nuo 18 iki $382 \theta$ laipsnių). Mineralai buvo indentifikuojami remiantis sudaryta duomenų baze (Raaz 1930; Goodwin et al. 1970; Wainwright et al. 1971; Peacor 1973; Hoerkner et al. 1976; Amour et al. 1978; Greaves 1983; Swanson et al. 1983; Kihara 1990; Balzar et al. 1993; Dove et al. 1993; Palmer et al. 1997; Cellai et al. 1999; Hirose et al. 2005; Xu et al. 2005; Rezaee et al. 2011 ir kt.).

Kristalinès fazès etalonu, esančiu žaliavinèse medžiagose, panaudotas anatazo mineralas $\left(\mathrm{TiO}_{2}\right)$. Neidentifikuotų plotų paklaidos rodiklis kito nuo 0 iki $2,3 \%$.

Medžiagu mikrostruktūra tiriama naudojant SEM JEOL JSM-7600F skenuojančiosios elektroninès mikroskopijos (SEM) prietaisą su rentgeno spinduliu energijos dispersiniu spektrometru (EDS) Inca Energy 350 (Oxford Instruments). Elektroninès mikroskopijos parametrai: $10 \mathrm{kV}$ ir $20 \mathrm{kV}$ ịtampa, atstumas iki bandinio paviršiaus nuo 7 iki $10 \mathrm{~mm}$. Mikrostruktūros ypatumai identifikuoti tiriant bandinių skèlimo paviršių. Vaizdas kuriamas registruojant antrinių elektronų signalą. Didinimas nuo 50 iki 100 000. Prieš atliekant tyrimą, skilimo paviršius padengtas plonu aukso sluoksniu ir vakuume garinant aukso elektrodą buvo naudojamas „QUORUM Q150R ES“ prietaisas.

Tiglio metodu ištirti bandiniai po trijų ir šešių ciklų (2.4 pav.) toliau naudoti apsauginio barjero parametrams nustatyti SEM ir EDS prietaisais, kurie leidžia atitinkamai ịvertinti barjero sluoksnio storị ir cheminę sudètį. Šiems bandymams atlikti išpjautas paveiktas $1 \mathrm{~cm}$ medžiagos sluoksnis (2 taškas 2.4 pav. a), bandiniai padengti epoksidine derva, kuri sukietinta kambario sąlygomis. Toliau bandiniai šlifuoti, poliruoti ir atlikti SEM ir EDS tyrimai.

Tabletès metodu tyrimai buvo atliekami skirtingiems šamoto užpildams (BOS 125, BOS 135, BOS 145) su $\mathrm{K}_{2} \mathrm{CO}_{3}$ druska ir be jos, taip pat su maltu kvarcinio smèlio priedu termiškai apdorojant, skirtingą laiką ir skirtingose temperatūrose. Šis tabletès metodas skirtas mineraloginei ir cheminei sudečiai nustatyti. Vienai tabletei suformuoti buvo imama $10 \mathrm{~g}$ sutrinto ir persijoto per sietą (sieto akučiu dydis $0,063 \mu \mathrm{m}$ ) šamoto užpildo arba mišinio su kvarco smèliu (2,5 \% nuo šamoto užpildo) ịskaitant $\mathrm{K}_{2} \mathrm{CO}_{3}$ druską, kurios kiekis mišinyje (10 \% perskaičiavus i $\mathrm{K}_{2} \mathrm{O}$ nuo šamoto užpildo) arba be jos. Tablete buvo (skersmuo 38 $\mathrm{mm}$ ir aukštis $5 \mathrm{~mm}$ ) suspaudžiama presu $180 \mathrm{kN}$ jèga. Iš skirtingų komponentų 
pagamintos tabletès buvo kaitinamos krosnyje atitinkamai $1100{ }^{\circ} \mathrm{C}$ ir $1200{ }^{\circ} \mathrm{C}$ temperatūroje 5, 10 ir 15 valandų. Po degimo tabletès išimtos iš krosnies, atvėsintos iki kambario temperatūros. Cheminei sudèčiai identifikuoti naudota visa tabletė. Rentgenografiniams tyrimams - tabletė susmulkinta ir dar kartą persijota per sietą (sieto akučių dydis $0,063 \mu \mathrm{m}$ ).

Bandiniai XRD tyrimams iš kalio nepaveikto sluoksnio (5 taškas 2.4 pav.) sumalti laboratoriniame malūne ir prasijoti sietu, kurių akučių dydis $0,063 \mu \mathrm{m}$.

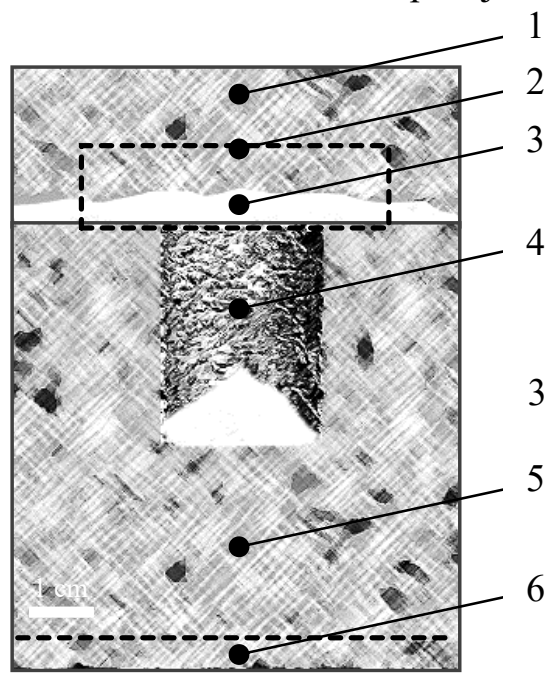

a)

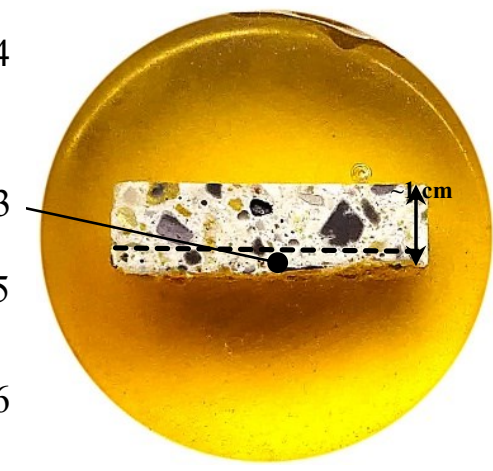

b)

2.4 pav. Tiglio metodo schema:

a) bandinio schema; b) šlifo vaizdas SEM - EDS tyrimams;

1 - betono plokštelè; 2 - bandinys naudojamas šlifo pagaminimui;

3 - plokštelès paviršiuje susidaręs apsauginis sluoksnis; 4 - ertmè $\mathrm{K}_{2} \mathrm{CO}_{3}$ druskai;

5 - tiriamasis bandinys; 6 - šarmų nepaveiktas betono bandinio sluoksnis panaudotas XRD tyrimams

Fig. 2.4. Crucible method scheme:

a) scheme of the sample; b) grind image for SEM - EDS studies;

1 - concrete plate; 2 - the sample used for the production of grind;

3 - a protective layer formed on the surface of the plate; 4 - cavity for $\mathrm{K}_{2} \mathrm{CO}_{3}$ salt;

5 - test sample; 6 - unaffected concrete layer was used for XRD studies

Tiriamujų medžiagų bandiniai buvo fotografuoti skaitmeniniu fotoaparatu „Sony ILCE 5000“.

Betonų destrukcijos vertinimui parinkta speciali metodika, kurioje naudojama vienpusio kaitinimo krosnis su atidaromu dangčiu (2.5 pav.).

Tyrimo metu $200 \times 200 \times 200 \mathrm{~mm}$ dydžio bandinys išdžiovintas ir iškaitintas iš vienos pusès pagal temperatūrinę kreivę pateiktą 2.6 pav. Tokiu būdu bandiniui 
imituotos realios pramoninio ịrenginio ịvedimo ị eksploataciją sąlygos. Vèliau atlikti terminiai ciklai naudojant ekstremalų režimą: temperatūros kèlimas vykdomas $300{ }^{\circ} \mathrm{C} / \mathrm{h}$ greičiu iki $900{ }^{\circ} \mathrm{C}$; 30min. išlaikymas $900{ }^{\circ} \mathrm{C}$ temperatūroje; aušinimas apie $400^{\circ} \mathrm{C} / \mathrm{h}$ su atidarytu dangčiu.

Atlikta 10 kaitinimo - aušinimo ciklų. Po kiekvieno ciklo ataušęs bandinys apžiūrètas fiksuojant atsiradusius įtrūkius ir išilgai bandinio, keturiuose taškuose, matuotas ultragarso impulso sklidimo laikas bei suskaičiuotas jo greitis.

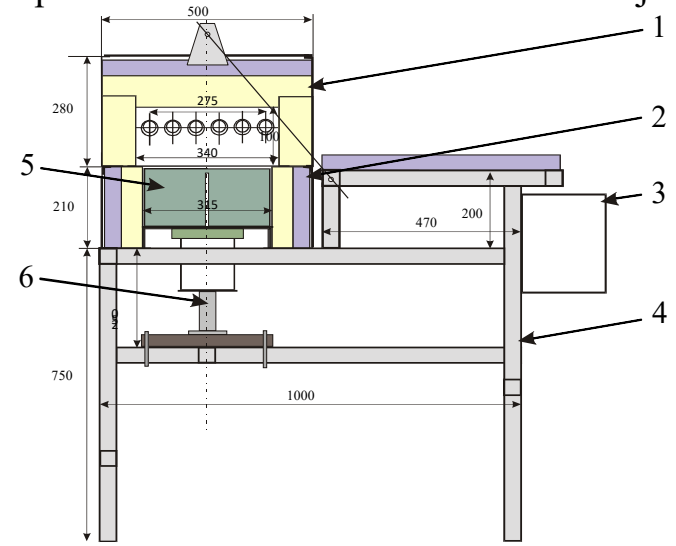

2.5 pav. Vienpusio kaitinimo ịrenginio schema:

1 - atidaromas dangtis su kaitinimo elementais; 2 - krosnies pagrindas;

3 - temperatūros reguliatorius; 4 - rèmas; 5 - betono bandinys;

6 - judantis staliukas bandinio išèmimui iš krosnies

Fig. 2.5. Scheme of one-sided test furnace:

1 - opening lid with heating elements; 2 - furnace base;

3 - temperature regulator; 4 - frame; 5 - castable sample;

6 - moving table for removing the sample from the furnace

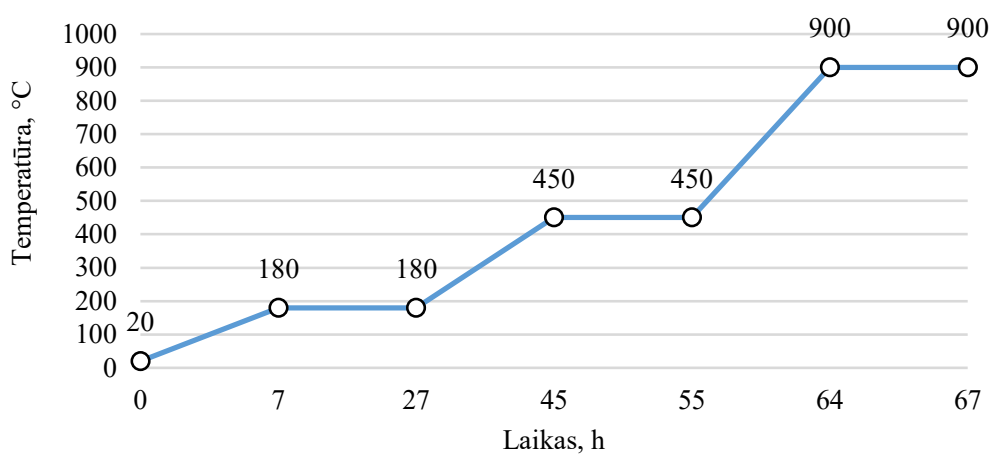

2.6 pav. Bandinio džiovinimo ir kaitinimo kreive

Fig. 2.6. Drying and heating curve of the castable samle, the heating of the first sample is given 
Matematinis tyrimų rezultatų apdorojimas buvo grindžiamas matematinès statistikos metodais (Čekanavičius 2004; Martinènas 2004; Liukaitis et al. 2006).

\subsection{Antrojo skyriaus išvados}

1. Šamotinių ugniai atsparių betonų šarminio atsparumo didinimui parinktos ịprastinio ir vidutinio cemento kiekio betonų sudètys su 2,5\% malto kvarcinio smèlio priedu, kuris sąveikauja su šarminiais junginiais ir skatina apsauginio barjero formavimąsi. Betono sudètyse bus naudojami ultradispersiniai priedai $\left(\mathrm{SiO}_{2}\right.$ mikrodulkès, reaktyvus aliuminio oksidas), kurie gali pagerinti matricos struktūrą ir betono fizikines, mechanines bei termines savybes.

2. Tiriamuose betonuose bus naudojami 3 rūšių šamoto užpildai su skirtingu $\mathrm{Al}_{2} \mathrm{O}_{3} / \mathrm{SiO}_{2}$ santykiu, kurie leis klasifikuoti ugniai atsparių betonų su šamoto užpildu šarminị atsparumą. 



\section{Šamotinių ugniai atsparių betony̨ savybių ir šarminio atsparumo tyrimai}

Skyriuje pateikti šie tyrimų rezultatai: šamoto užpildų, su skirtingu $\mathrm{Al}_{2} \mathrm{O}_{3} / \mathrm{SiO}_{2}$ santykiu $(0,44 ; 0,68 ; 0,89)$, šarminio atsparumo vertinimas, panaudojant rentgeno fazinius tyrimus; ịprastinio ir vidutinio cemento kiekio šamotinių betonų su malto kvarcinio smèlio priedu fizikinès, mechaninès, terminès ir šarminio atsparumo charakteristikos priklausomai nuo užpildo $\mathrm{Al}_{2} \mathrm{O}_{3} / \mathrm{SiO}_{2}$ santykio. Taip pat aprašyti atsparaus šarminei korozijai barjero formavimosi ypatumai, nustatyti barjero parametrai.

Šio skyriaus medžiaga paskelbta keturiose autoriaus (su bendraautoriais) straipsniuose (Boris et al. 2017; Antonovič et al. 2019; Zdanevičius et al. 2019; Antonovič et al. 2020) ir pristatyta šešiose konferencijose.

\section{1. Šamoto užpildo šarminio atsparumo ịvertinimas panaudojant rentgeno fazinius tyrimus}

Šamoto užpildai gaminti išdegant kaoliną, smulkinant ugniai atsparių gaminių laužą arba šamotines atliekas. Šiai grupei priskirti aliumosilikatai, kurių $\mathrm{Al}_{2} \mathrm{O}_{3}$ 
kiekis yra $25 \%$ - $45 \%$ (Sadik et al. 2014). Ugniai atspariems betonams gaminti panaudoti šamoto užpildai, kurie yra klasifikuojami pagal $\mathrm{Al}_{2} \mathrm{O}_{3}$ kieki ir turintys jo ne mažiau kaip $25 \%$. Aliumosilikatiniai užpildai, turintys $\mathrm{Al}_{2} \mathrm{O}_{3}$ nuo 10 iki $30 \%$, yra priskiriami silikatinių šamoto užpildų tipui (Роучка et al. 2010:55-56). Šamotas kaip žaliava turi ir tokius oksidus kaip $\mathrm{Fe}_{2} \mathrm{O}_{3}, \mathrm{TiO}_{2}, \mathrm{CaO}, \mathrm{MgO}, \mathrm{Na}_{2} \mathrm{O}$ ir $\mathrm{K}_{2} \mathrm{O}$, kurių kiekis yra pakankamai mažas (Deutsche Gesellschaft Feuerfest-und Schornsteinbau 2005).

Darbe buvo panaudoti šamoto užpildai, kuriose $\mathrm{Al}_{2} \mathrm{O}_{3} / \mathrm{SiO}_{2}$ santykiu 0,44 , 0,68 ir 0,89 (2.1 lentelè). Rentgenografiniams tyrimams buvo naudoti šamoto milteliai ir/arba išdegtos ir susmulkintos tabletès (frakcija $0,063 \mu \mathrm{m}$ ).

Analizuojant gautus rezultatus, užfiksuota pagrindinių mineralų smailių suma, kuri prilyginta $100 \%$. Apskaičiuotas kiekvieno mineralo intensyvumas žemiau pateikiamas paveiksluose.

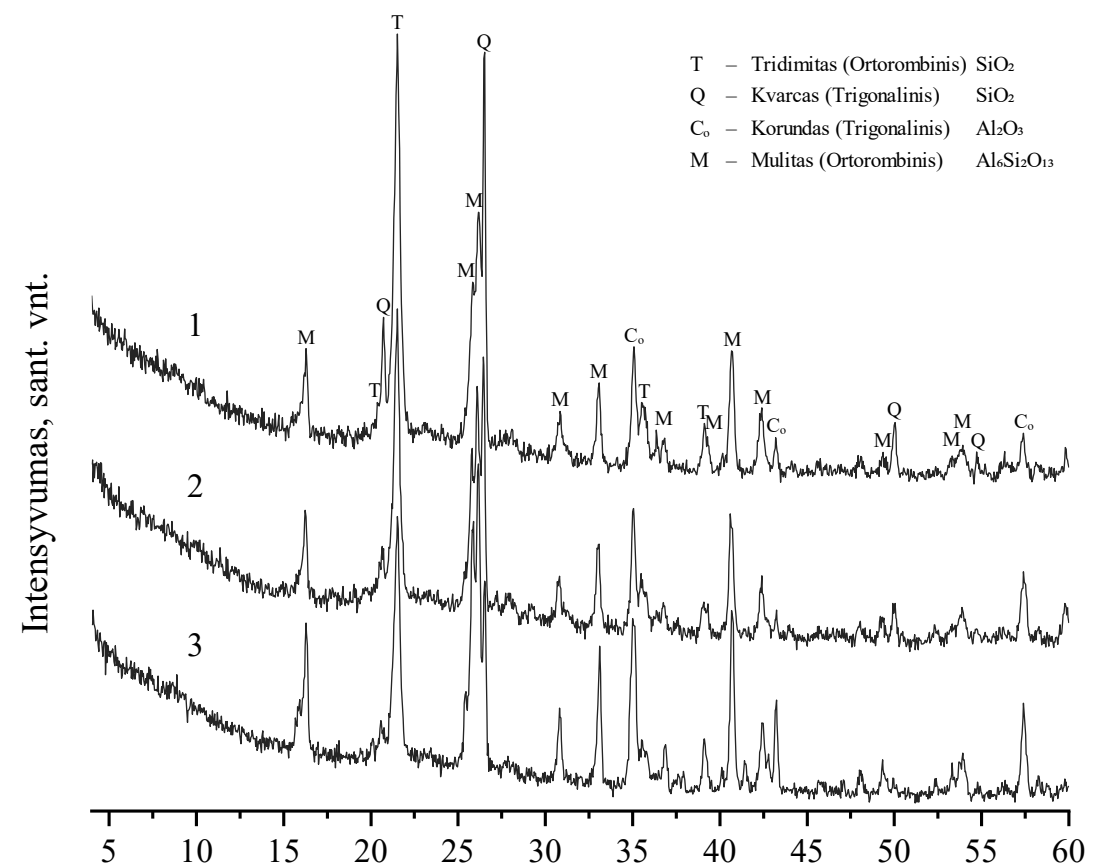

Difrakcijos kampas 20, laipsniais

3.1 pav. Šamoto užpildo rentgenogramos: 1 - BOS $125 ; 2$ - BOS $135 ; 3$ - BOS 145

Fig. 3.1. X-ray pattern of fireclay filler:

1 - BOS 125; 2 - BOS 135; 3 - BOS 145 
3.1 paveiksle pateiktos užpildų pradinès rentgenogramos, kuriose identifikuotos tokios mineralų fazès: tridimitas, kvarcas, korundas ir mulitas. Jose galima pastebèti ir tam tikrą stiklo fazès kiekị (esant $20^{\circ}-25^{\circ}$ kampo intervalui). Priklausomai nuo šamoto užpildo markès aukščiau paminètų mineralų pagrindinių smailių intensyvumai yra skirtingi. Kuo didesnis $\mathrm{Al}_{2} \mathrm{O}_{3}$ kiekis medžiagoje, o tuo pačiu didesnès $\mathrm{Al}_{2} \mathrm{O}_{3} / \mathrm{SiO}_{2}$ santykio vertès $(\mathrm{BOS} 125=0,44$; $\mathrm{BOS} 135=0,68$; BOS $145=0,89)$, tuo mulito smailių intensyvumas yra didesnis ir yra mažesni kvarco ir tridimito smailių intensyvumai.

Kaip matyti iš 3.2 paveikslo mulito kiekis BOS 125 markèje $22,8 \%$. Tuo tarpu kvarco, tridimito ir korundo kiekis sudaro atitinkamai 34,7\%,36,1\% ir $6,4 \%$, sudarant $100 \%$. Tuo tarpu BOS 135 markejje analogiškai mulito kiekis sudaro $26,9 \%, 29,5 \%, 33,8 \%$ ir $9,9 \%$ taip pat sudarant $100 \%$ ir kt. Atitinkamai šamoto rūšis atspindi mineralų kitimo tendencijas: mulito ir korundo kiekio didejimą tokia tvarka: BOS $125 \rightarrow$ BOS $135 \rightarrow$ BOS 145 ir atvirkščia tvarka kvarco ir tridimito atveju.

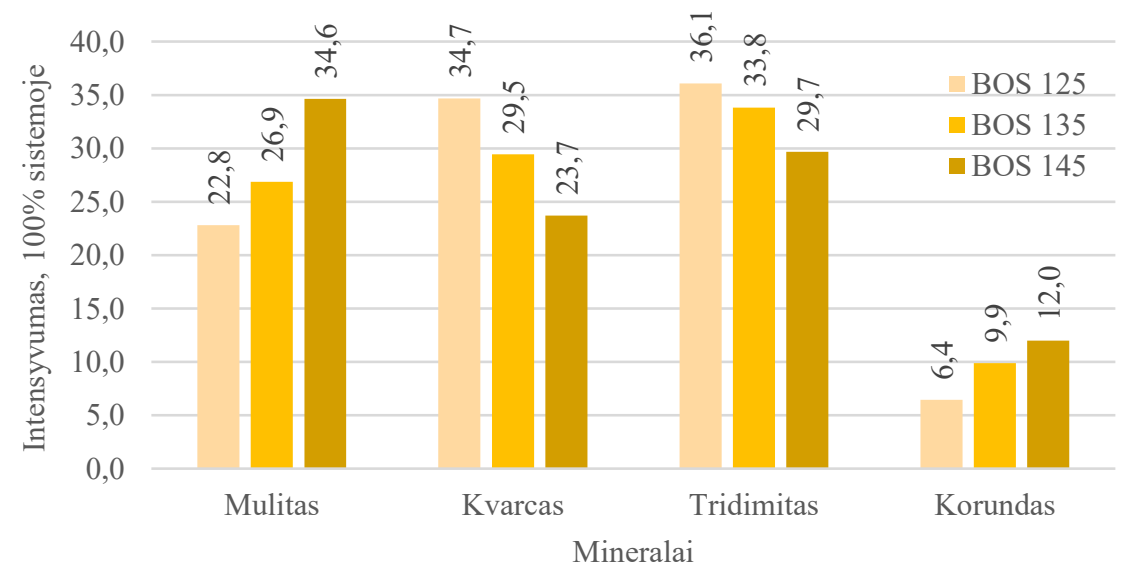

3.2 pav. Šamoto užpildų mineralų intensyvumas pagal rentgenografinių tyrimų rezultatus

Fig. 3.2. Mineral intensity of fireclay aggregate according to the results of X-ray examinations

Šamoto užpildo mišinyje su kalio karbonatu (3.3 pav.) jau po 5 val. degimo $1100{ }^{\circ} \mathrm{C}$ temperatūroje identifikuoti mulitas, kvarcas, tridimitas, korundas ir korozijos produktai - kalsilitas ir leucitas. Panašūs rezultatai gauti (Scudeller et al. 1990) darbe, kurio autoriai tiriant metalurginio kokso ir kalio karbonato poveiki aliumosilikatinèms medžiagoms $\left(\mathrm{Al}_{2} \mathrm{O}_{3}\right.$ kiekis siekė $\left.45 \%-55 \%\right)$ $1000{ }^{\circ} \mathrm{C}$ temperatūroje identifikavo kaliofilita (heksagonalinè kalsilito atmaina) ir leucita. Kalsilito, mūsų atveju, ar kaliofilito (aukščiau minètame darbe) 
susidarymą galëjo lemti kaip cheminè medžiagos sudètis, kalio kiekis ir medžiagoje esančios priemaišos ar net ir reagente esanti anglis (Narita et al. 1981).

Analizuojant iškaitintu skirtingu šamoto užpildų su $\mathrm{K}_{2} \mathrm{CO}_{3}$ druska susidariusią mineraloginę sudètị (3.4 pav.) priklausomai nuo šamoto $\mathrm{Al}_{2} \mathrm{O}_{3} / \mathrm{SiO}_{2}$ santykio, korozijos produktų smailių intensyvumai yra skirtingi: kuo didesnis aliuminio oksido kiekis užpilde, (atitinkamai mažesnis silicio oksido kiekis) tuo kalsilito $-\mathrm{KAlSiO}_{4}(\mathrm{~d}=0,312 ; 0,258 ; 0,218 \mathrm{~nm})$ atsižvelgiant $\mathfrak{i}$ DRON-7 programinę ịrangą - (El-Meliegy et al. 2012:170) intensyvumas yra didesnis, o leucito $\mathrm{KAlSi}_{2} \mathrm{O}_{6}(\mathrm{~d}=0,327 ; 0,345 ; 0,541 \mathrm{~nm})$ mažesnis. Leucito smailès palyginus su kalsilito smailèmis yra didesnès ir jų intensyvumas sudaro nuo $18,3 \%$ iki $28,3 \%$ (3.4 pav.).

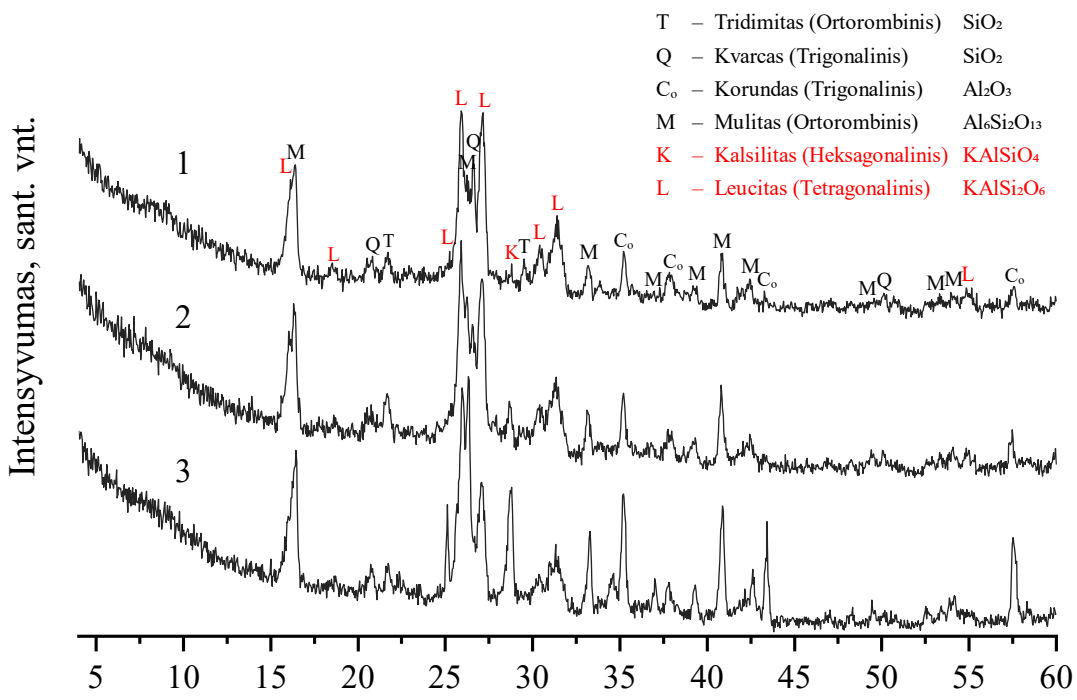

Difrakcijos kampas 20, laipsniais

3.3 pav. Šamoto užpildo su $\mathrm{K}_{2} \mathrm{CO}_{3}$ bandinių, degtų 5 val. $1100^{\circ} \mathrm{C}$ temperatūroje rentgenogramos:

1 - BOS 125; 2 - BOS 135; 3 - BOS 145

Fig. 3.3. X-ray pattern of fireclay aggregates treated with $\mathrm{K}_{2} \mathrm{CO}_{3}$ at $1100{ }^{\circ} \mathrm{C}$ for $5 \mathrm{~h}$ : 1 - BOS 125; 2 - BOS 135; 3 - BOS 145 


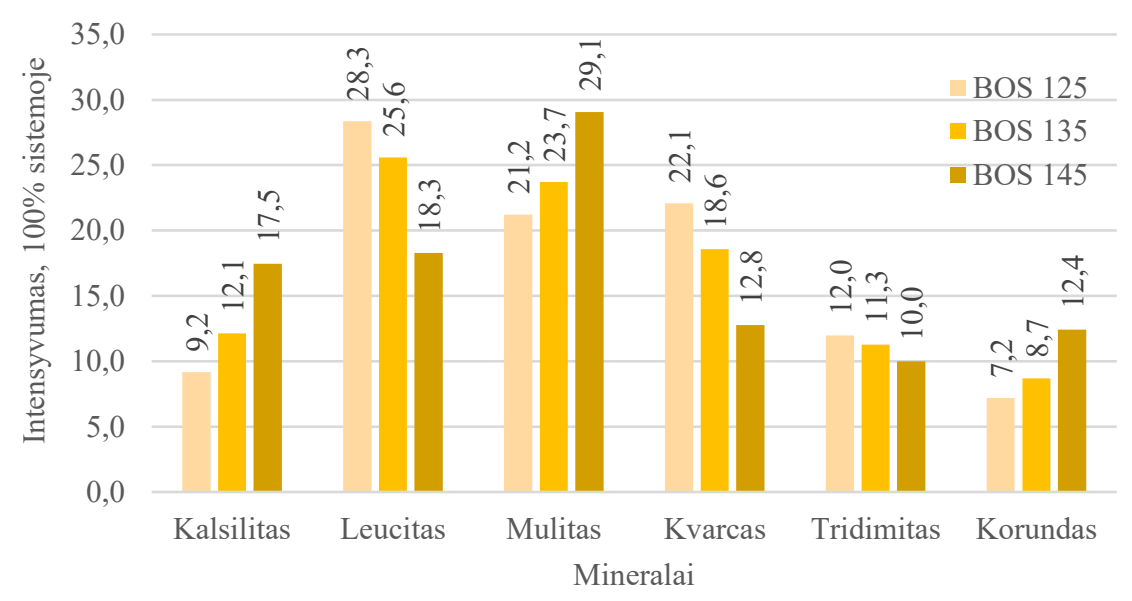

3.4 pav. Šamoto užpildo su $\mathrm{K}_{2} \mathrm{CO}_{3}$ bandinių, degtų 5 val. $1100^{\circ} \mathrm{C}$ temperatūroje, mineralų intensyvumas pagal rentgenografinių tyrimų rezultatus

Fig. 3.4. The intensities of the minerals of chamotte aggregates with $\mathrm{K}_{2} \mathrm{CO}_{3}$ samples fired for 5 hours at $1100{ }^{\circ} \mathrm{C}$ according to the results of X-ray examinations

3.4 paveiksle iliustruoja, kad korozijos produktų - kalsilito ir leucito susidarymo reakcijose neabejotinai dalyvauja mulitas, kvarcas, tridimitas ir korundas.

L. Scudeller (Scudeller et al. 1990) aprašo tendencijas, kad pirmiausiai reakcijos vyksta medžiagos stiklo fazejje $\left(\mathrm{K}_{2} \mathrm{O}\right.$ reaguoja $\left.\mathrm{su} \mathrm{SiO}_{2}\right)$, vèliau kontaktinejje zonoje tarp medžiagos matricos ir mulito grūdelių susidarant kaliofilitui (šiuo atveju kalsilitas). Šis naujadaras nèra stabilus ir vèliau formuojasi termodinamiškai stabilus leucitas, kurio kiekis padideja.

Ilginant bandinių degimo laiką iki 10 valandų $1100{ }^{\circ} \mathrm{C}$ temperatūroje (3.5 pav.) kalsilito kiekis tendencingai mažèja, o tuo tarpu leucito - didèja. Mulito, tridimito ir korundo kiekiai mažeja, o kvarco - didèja. Darbe (Geith et al. 2001) nurodoma, kad formuojantis leucitui pakankamai žemose temperatūrose $\left(760-930{ }^{\circ} \mathrm{C}\right.$ intervale), kristobalitas arba kvarcas (mūsų atveju tridimitas ir kvarcas) tirpsta stiklo fazès tirpale. Tokị reiškinị savo darbe pastebi ir T. Hayashi (Hayashi et al. 1979).

Tačiau reikia pabrèžti, (3.4 pav.) kad naujadarų (korozijos produktų) kalsilito ir leucito sintezę nulemia ir šamoto markès. Kalsilito didejjimo tvarka pagal šamoto užpildo $\mathrm{Al}_{2} \mathrm{O}_{3} / \mathrm{SiO}_{2}$ santyki yra ši: $0,44 \rightarrow 0,68 \rightarrow 0,89$, o leucito atvirkščia nurodytoms markèms. Tuo tarpu reakcijoje dalyvaujančių mineralų tvarka lieka ta pati priklausomai nuo konkretaus mineralo: mulitas ir korundas didèja tokia tvarka $0,44 \rightarrow 0,68 \rightarrow 0,89$, o kvarcui ir tridimitui ši seka atvirkščia. 


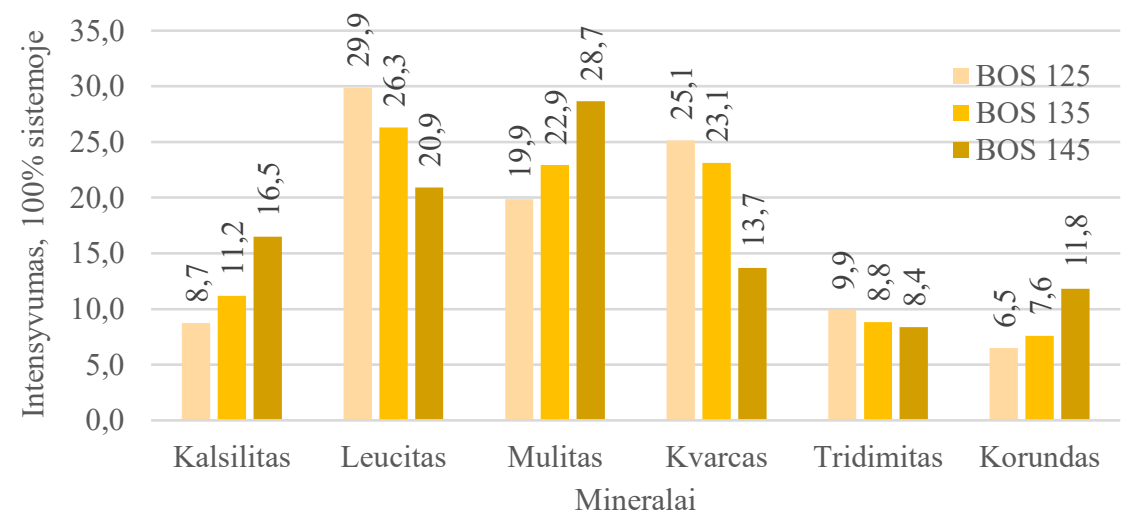

3.5 pav. Šamoto užpildo su $\mathrm{K}_{2} \mathrm{CO}_{3}$ bandinių, degtų 10 val. $1100^{\circ} \mathrm{C}$ temperatūroje, mineralų intensyvumas pagal rentgenografinių tyrimų rezultatus

Fig. 3.5. The intensities of the minerals of chamotte aggregates with $\mathrm{K}_{2} \mathrm{CO}_{3}$ samples fired for 10 hours at $1100^{\circ} \mathrm{C}$ according to the results of X-ray examinations

Kaip matome (3.6 pav.), analogiška naujadarų ir bazinių mineralų kitimo tendencija matoma išlaikymo laiką prailginus iki 15 valandų $1100{ }^{\circ} \mathrm{C}$ temperatūroje.

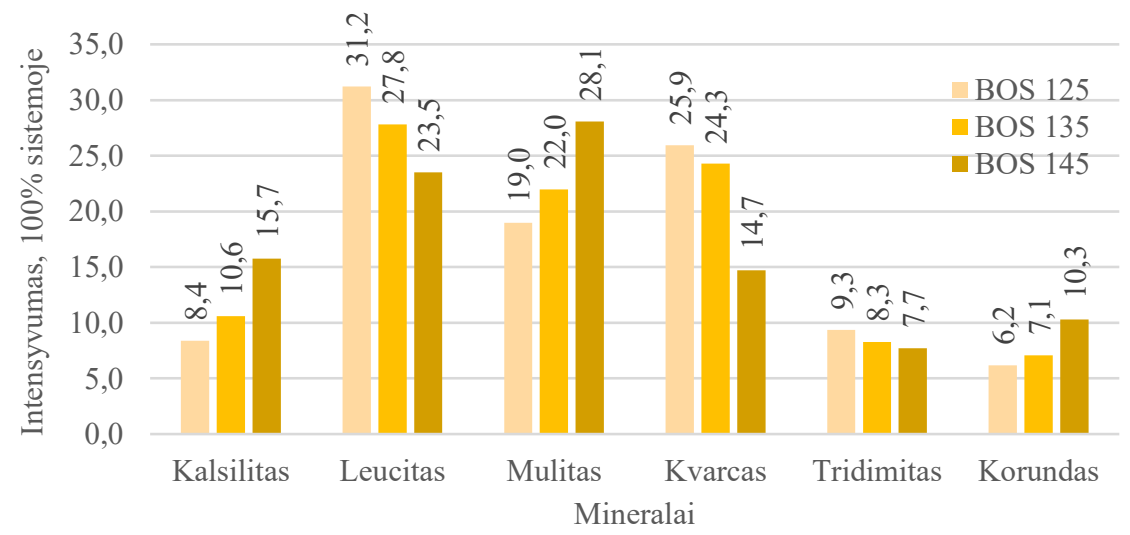

3.6 pav. Šamoto užpildo su $\mathrm{K}_{2} \mathrm{CO}_{3}$ bandinių, degtų 15 val. $1100{ }^{\circ} \mathrm{C}$ temperatūroje, mineralų intensyvumas pagal rentgenografinių tyrimų rezultatus

Fig. 3.6. The intensities of the minerals of chamotte aggregates with $\mathrm{K}_{2} \mathrm{CO}_{3}$ samples fired for 15 hours at $1100{ }^{\circ} \mathrm{C}$ according to the results of X-ray examinations 


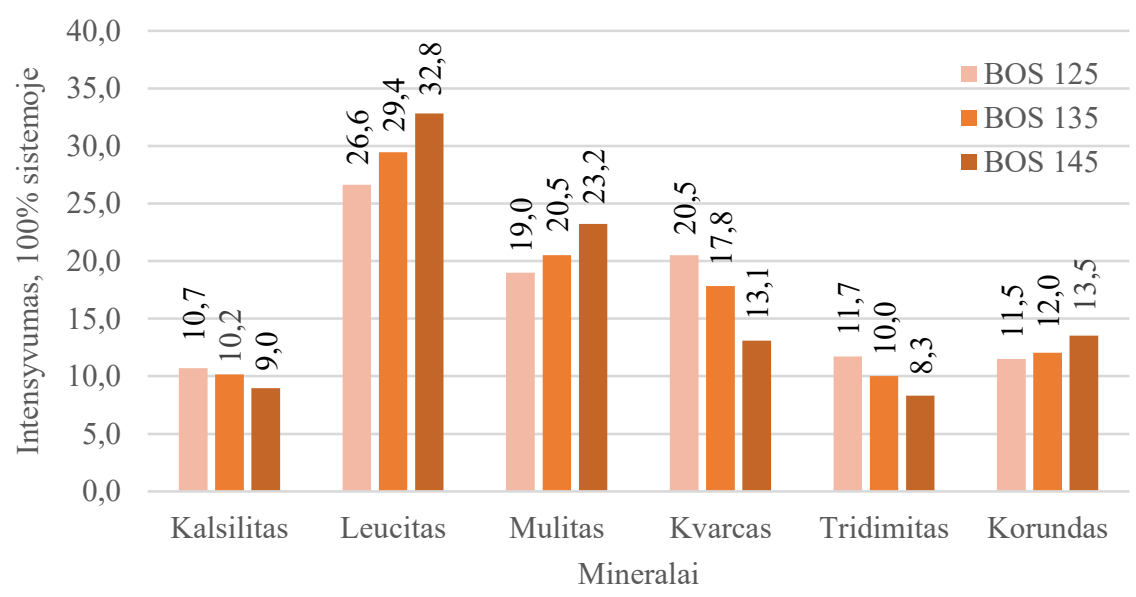

3.7 pav. Šamoto užpildo su $\mathrm{K}_{2} \mathrm{CO}_{3}$ bandinių, degtų 5 val. $1200^{\circ} \mathrm{C}$ temperatūroje, mineralų intensyvumas pagal rentgenografinių tyrimų rezultatus

Fig. 3.7. The intensities of the minerals of chamotte aggregates with $\mathrm{K}_{2} \mathrm{CO}_{3}$ samples fired for 5 hours at $1200{ }^{\circ} \mathrm{C}$ according to the results of X-ray examinations

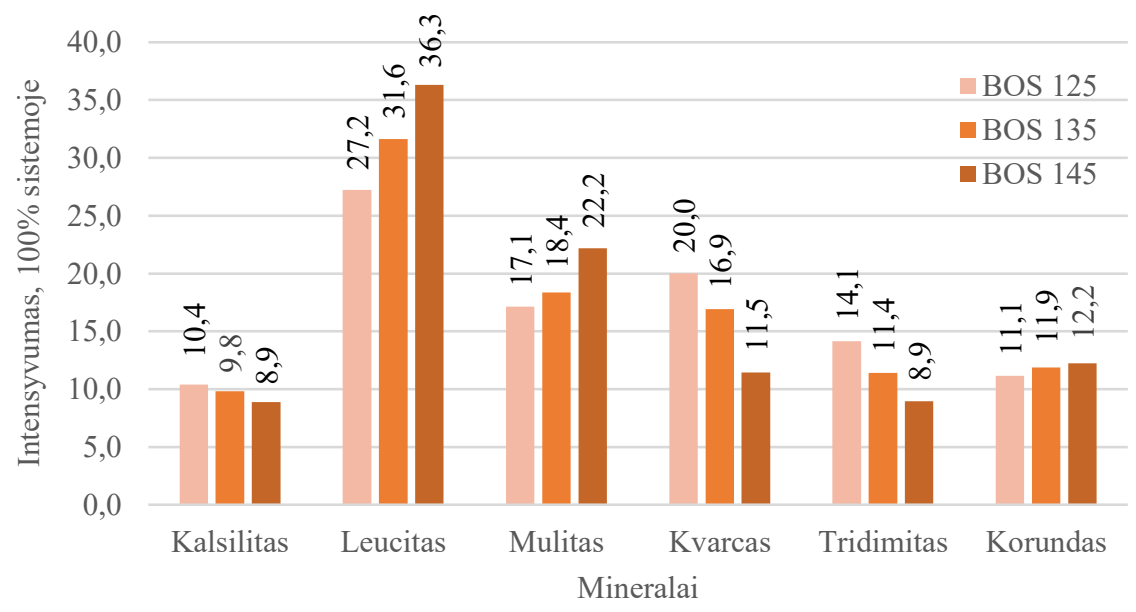

3.8 pav. Šamoto užpildo su $\mathrm{K}_{2} \mathrm{CO}_{3}$ bandinių, degtụ 15 val. $1200{ }^{\circ} \mathrm{C}$ temperatūroje, mineralų intensyvumas pagal rentgenografinių tyrimų rezultatus

Fig. 3.8. The intensities of the minerals of chamotte aggregates with $\mathrm{K}_{2} \mathrm{CO}_{3}$ samples fired for 15 hours at $1200^{\circ} \mathrm{C}$ according to the results of X-ray examinations 
Po 5 ir 15 valandų padidintoje temperatūroje iki $1200{ }^{\circ} \mathrm{C}$ naujadaru (kalsilito ir leucito) kitimo tendencijos, priklausomai nuo $\mathrm{Al}_{2} \mathrm{O}_{3} / \mathrm{SiO}_{2}$ santykio, pakinta palyginus su aukščiau pateiktais tyrimų rezultatais. Jeigu pagal ankstesnius tyrimu rezultatus turime seką: $0,44 \rightarrow 0,68$ $\rightarrow 0,89$, kaip korozijos produktų augimo tendenciją, tai aukštesnèje temperatūroje ši tendencija tampa priešinga: $0,89 \rightarrow 0,68 \rightarrow 0,44$. Mulito, kvarco, tridimito ir korundo kitimo tendencijos priklausomai nuo šamoto užpildo markès ir žemesnèje, ir aukštesnèje ekspozicijos temperatūroje išlieka tos pačios.

Palyginus tyrimų rezultatus po 5 ir 15 valandų ( 3.7 pav. ir 3.8 pav.) išlaikymo $1200^{\circ} \mathrm{C}$ temperatūroje, matome kalsilito sumažejimo tendenciją ir leucito padidejjimo ilginant išlaikymo laiką. Tos pačios tendencijos laiko atžvilgiu buvo stebimos ir prie $1100{ }^{\circ} \mathrm{C}$ (3.4 pav. - 3.6 pav.). Tuo tarpu bazinių mineralų atžvilgiu dalyvaujančių cheminèse naujadaru susidarymo reakcijose mulito ir korundo atveju stebime analogišką tendenciją nepriklausomai nuo išlaikymo temperatūros $\left(1100{ }^{\circ} \mathrm{C}\right.$ ir $\left.1200{ }^{\circ} \mathrm{C}\right)$.

Po $1100{ }^{\circ} \mathrm{C}$ arba $1200{ }^{\circ} \mathrm{C}$ temperatūros kvarco ir tridimito atveju pasireiškia priešinga tendencija: kvarco kiekis nežymiai mažèja, o tridimito atitinkamai didèja (3.7 pav. -3.8 pav.).

Tolesnis bandymų tikslas buvo atsakyti i klausimą, ar papildomas kvarco kiekis daro įtaką kalsilito ir leucito kiekiui, kadangi jų kiekio sumažejimas reikštų korozijos proceso sulètèjimą. Tuo tikslu naudojant tabletès metodą, i atitinkamą susmulkintą užpildą papildomai buvo ịvesta 2,5\% kvarcinio smèlio. Kaip matyti iš pateiktų duomenų 3.9 paveiksle (apdorojant 5 valandas $1100{ }^{\circ} \mathrm{C}$ temperatūroje), kalsilitas turi tendenciją mažèti, o leucitas - didèti. Tuo tarpu kvarcas didèti, o mulitas, tridimitas ir korundas - mažèti. Analogiškos tendencijos stebètos ir pradinių bandymų atvejais (3.4 pav. - 3.6 pav.).

Duomenys pateikti po 10 ir 15 valandų $1100{ }^{\circ} \mathrm{C}$ temperatūroje su papildomu kvarco kiekiu pasižymi analogiškomis kitimo tendencijomis (3.10 pav. - 3.11 pav.). Absoliutūs kalsilito kiekiai palyginus su pirminiais tyrimu rezultatais (3.4 pav. - 3.6 pav.) yra artimi. Tuo tarpu naujadaro leucito kiekis padidèja, o mulito atitinkamai sumažèja. Taip pat būtina pažymèti, kad santykinai korundo kiekis mažèja léčiau, o tridimito sparčiau ilginant degimo trukmę (3.9 pav. - 3.11 pav.). Taip paaiškinama tuo, kad tridimitas lengvai pereina ì lydalą ir dalyvauja korozijos produktų susidaryme. 


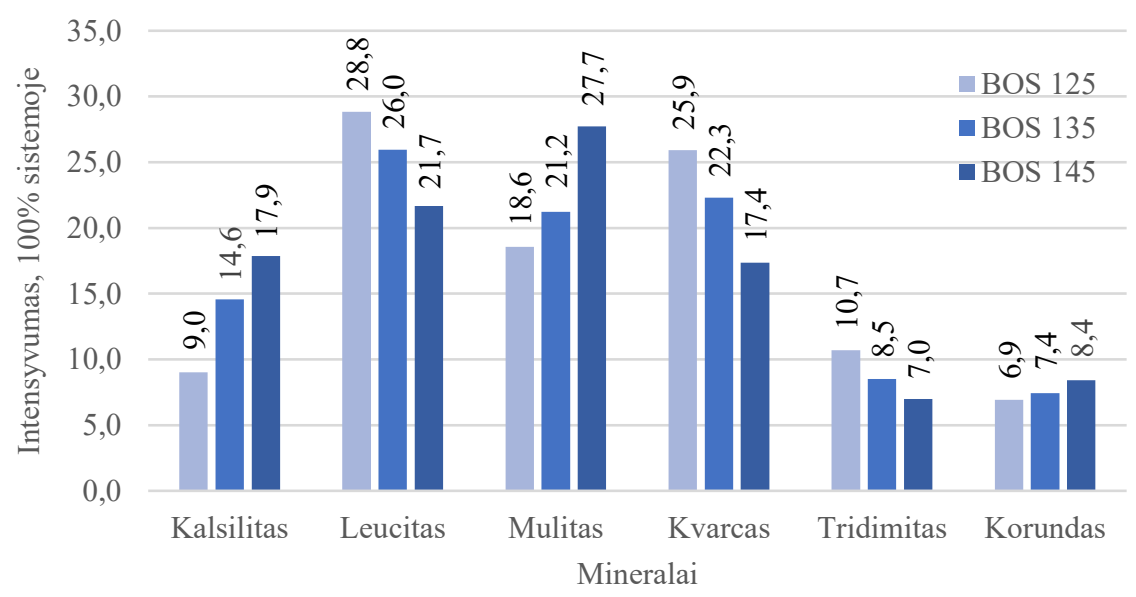

3.9 pav. Šamoto užpildo su $\mathrm{K}_{2} \mathrm{CO}_{3}$ bandinių, degtų 5 val. $1100^{\circ} \mathrm{C}$ temperatūroje, mineralų intensyvumas pagal rentgenografinių tyrimų rezultatus

Fig. 3.9. The intensities of the minerals of chamotte aggregates with $\mathrm{K}_{2} \mathrm{CO}_{3}$ samples fired for 5 hours at $1100{ }^{\circ} \mathrm{C}$ according to the results of X-ray examinations

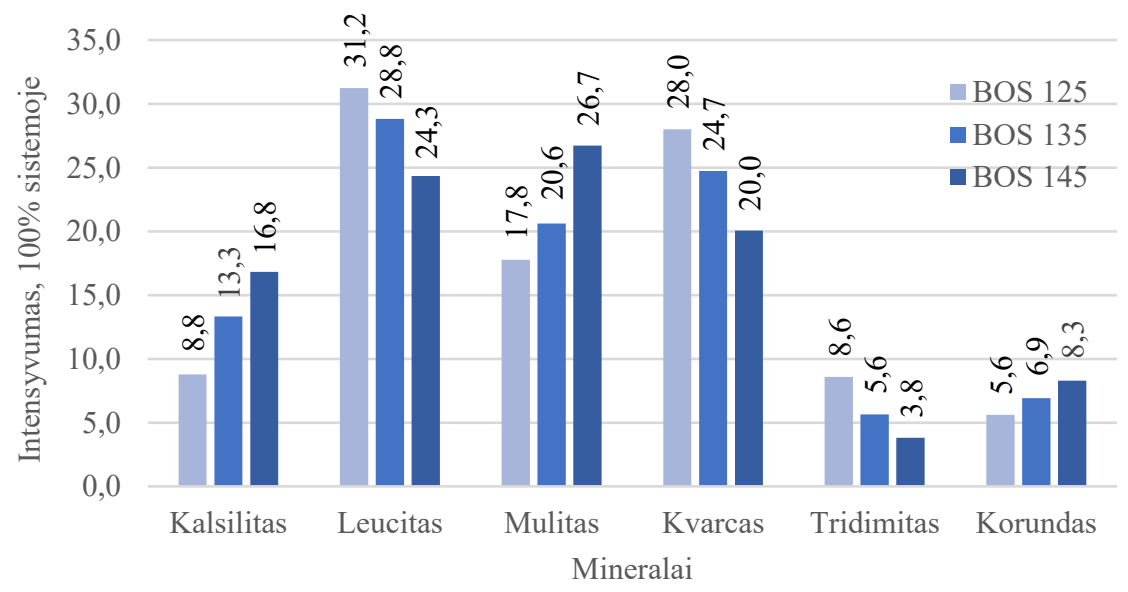

3.10 pav. Šamoto užpildo su $\mathrm{K}_{2} \mathrm{CO}_{3}$ bandinių, degtų 10 val. $1100{ }^{\circ} \mathrm{C}$ temperatūroje, mineralų intensyvumas pagal rentgenografinių tyrimų rezultatus

Fig. 3.10. The intensities of the minerals of chamotte aggregates with $\mathrm{K}_{2} \mathrm{CO}_{3}$ samples fired for 10 hours at $1100^{\circ} \mathrm{C}$ according to the results of X-ray examinations 


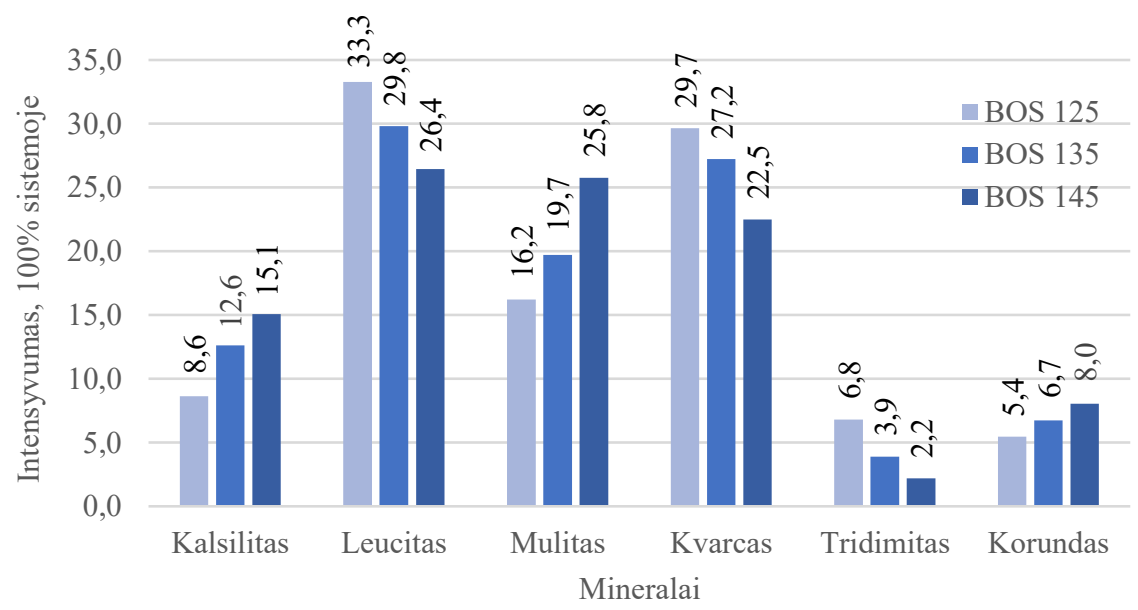

3.11 pav. Šamoto užpildo su $\mathrm{K}_{2} \mathrm{CO}_{3}$ bandinių, degtų 15 val. $1100{ }^{\circ} \mathrm{C}$ temperatūroje, mineralų intensyvumas pagal rentgenografinių tyrimų rezultatus

Fig. 3.11. The intensities of the minerals of chamotte aggregates with $\mathrm{K}_{2} \mathrm{CO}_{3}$ samples fired for 15 hours at $1100{ }^{\circ} \mathrm{C}$ according to the results of X-ray examinations

3.10-3.11 paveiksluose pateikti duomenys rodo, kad pridejus i susmulkinto šamoto miltelius papildomai kvarcinio smèlio, išauga ir absoliutus kvarco kiekis sistemoje. Žinoma, kaip aukščiau pastebėta, ir mulitas, ir kvarcas, ir tridimitas, ir korundas tikètinai dalyvauja koroziją skatinančių naujadarų susidarymo ir kitimo, priklausomai nuo laiko ir temperatūros, reakcijose.

Taip pat reikia pastebèti, kad formuojantis leucitui naujadarų tūrio padidejimas yra didesnis palyginus su struktūra, kurioje formuojasi kalsilitas (Geith et al. 2001). Tai reiškia, kad skirtingo $\mathrm{Al}_{2} \mathrm{O}_{3} / \mathrm{SiO}_{2}$ santykio šamoto medžiagos irimo laipsnis gali būti skirtingas.

Tyrimai rodo, kad visais atvejais, tame tarpe ir su kvarcinio smèlio priedu, sistemos su šamoto užpildais gana lengvai ir greitai koroduoja sąveikoje su kaliu garo būsenoje $1100{ }^{\circ} \mathrm{C}$ ir $1200{ }^{\circ} \mathrm{C}$ temperatūrose. Tai reiškia, kad norint apsaugoti aliumosilikatinę medžiagą nuo šarminès korozijos, turi būti sustabdytas arba apsunkintas šarminių junginiu skverbimasis ị jos struktūrą. 


\subsection{Ugniai atsparaus betono su šamoto užpildu fizikinių, mechaninių ir terminių savybių tyrimas}

Šarminių junginių skverbimasis ị ugniai atsparaus betono struktūrą gali būti apsunkintas naudojant ultradispersinius priedus (šiame darbe $\mathrm{SiO}_{2}$ mikrodulkès ir aliuminio oksidas), mažinančius betono poringumą, arba reakcingus priedus, skatinančius atsparaus šarminiams junginiams barjero susiformavimą. Veikiant šarminiam lydalui, pastarasis gali susidaryti, jeigu betone yra reaktyvusis kvarcas. Šiame darbe naudojamas malto kvarcinio smèlio priedas.

\subsubsection{Iprastinio ugniai atsparaus betono, su skirtingais šamoto užpildais ir modifikuojančiais priedais, savybių tyrimai}

Iprastiniai ugniai atsparūs betonai pasižymi pakankamai žemais eksploatacinių savybių rodikliais: gniuždymo stipris po degimo $1100^{\circ} \mathrm{C}$ temperatūroje $<25 \mathrm{MPa}$ (Goberis et al. 2007: 136-140; Шишков et al. 1978), о јų atviras poringumas siekia $\sim 30 \%$ po degimo $800{ }^{\circ} \mathrm{C}$ temperatūroje (Замятин et al. 1982: 119-120).

3.1 lentelè. $B$ ir BQ serijų betonų charakteristikos

Table 3.1. Characteristics of $B$ and $B Q$ series castable

\begin{tabular}{|c|c|c|c|c|c|c|}
\hline \multirow{2}{*}{ Charakteristika } & \multicolumn{7}{|c|}{ Betono sudèties žymuo } \\
\cline { 2 - 7 } & B2 & B3 & B4 & BQ2 & BQ3 & BQ4 \\
\hline $\begin{array}{c}\text { Tankis, } \mathrm{kg} / \mathrm{m}^{3}: \\
\text { po džiovinimo } 110^{\circ} \mathrm{C}\end{array}$ & 2080 & 2080 & 2260 & 2090 & 2100 & 2240 \\
po degimo $1100^{\circ} \mathrm{C}$ & 1960 & 1960 & 2140 & 1970 & 1990 & 2120 \\
\hline $\begin{array}{c}\text { Gniuždymo stipris, MPa: } \\
\text { po džiovinimo } 110^{\circ} \mathrm{C}\end{array}$ & 71 & 71 & 109 & 73 & 76 & 105 \\
po degimo $1100^{\circ} \mathrm{C}$ & 44 & 44 & 66 & 46 & 51 & 67 \\
\hline $\begin{array}{c}\text { Poringumas, \%: } \\
\text { po degimo } 1100^{\circ} \mathrm{C}\end{array}$ & 26,2 & 27,2 & 23,0 & 24,5 & 24,0 & 22,2 \\
po degimo $1200^{\circ} \mathrm{C}$ & - & - & - & 26,4 & 25,3 & 23,1 \\
\hline Terminis atsparumas, ciklais & 9 & 11 & 20 & 8 & 10 & 17 \\
\hline
\end{tabular}

Pastaba: Atliktiems tyrimų rezultatams paskaičiuoti variacijos koeficientai yra: tankiui $0,62 \%$; gniuždymo stipriui $3,44 \%$; terminiam atsparumui $4,87 \%$ ir poringumui $5,13 \%$.

Šiame darbe B ir BQ serijų (2.2 lentelè) ịprastiniai betonai su šamoto užpildais modifikuoti $\mathrm{SiO}_{2}$ mikrodulkèmis ir deflokuliantu pasižymi pakankamai artimu tankiu po džiovinimo ir degimo $1100{ }^{\circ} \mathrm{C}$ temperatūroje, 
kuris turi didejjimo tendenciją priklausomai nuo $\mathrm{Al}_{2} \mathrm{O}_{3} / \mathrm{SiO}_{2}$ santykio $(\operatorname{BOS} 125=0,44 ; \operatorname{BOS} 135=0,68$; BOS $145=0,89)$. Panaši tendencija matoma ir gniuždymo stiprio atžvilgiu po džiovinimo ir degimo. Tuo tarpu poringumo rodiklio atžvilgiu (po degimo esant $1100^{\circ} \mathrm{C}$ ir $1200{ }^{\circ} \mathrm{C}$ ), ypač $\mathrm{BQ}$ serijoje, fiksuojama atvirkštinè tendencija $\mathrm{Al}_{2} \mathrm{O}_{3} / \mathrm{SiO}_{2}$ santykio kitimo atžvilgiu (3.1 lentelè).

Tyrimai parodè, kad modifikuoti B ir BQ serijos ịprastiniai betonai, palyginus su nemodifikuotais šamotbetoniais (chrakteristikos aprašytos aukščiau), pasižymi pakankamai dideliu gniuždymo stipriu $>40 \mathrm{MPa}$ po degimo $1100{ }^{\circ} \mathrm{C}$ temperatūroje ir mažesniu atviru poringumu $<28 \%$. Naudojant BOS 145 užpildą, jo atviras poringumas po degimo $1100{ }^{\circ} \mathrm{C}$ temperatūroje B4 ir BQ4 betonuose siekia tik $23,0 \%$ ir $22,2 \%$ atitinkamai (3.1 lentelè).

Tai aiškinama žinomais panaudotų aktyvių priedų efektais: deflokulianto - vandens poreikio betono pagaminimui mažinimu, $\mathrm{SiO}_{2}$ mikrodulkių - tuštumų betono mišinyje užpildymu bei dalyvavimu kalcio aliuminatinio cemento hidratacijos reakcijose (aprašyta 1.5 poskyryje).

Nepriklausomai nuo modifikuojančių priedų bendro teigiamo poveikio (B ir BQ serijų) betonų charakteristikoms, pastebimas iprastiniams ugniai atspariems betonams charakteringas gniuždymo stiprio sumažejjimas: po džiovinimo stiprio vertès siekia $71-109 \mathrm{MPa}$, o po degimo $1100{ }^{\circ} \mathrm{C}$ temperatūroje jos siekia 44-67 MPa. Šio proceso eigoje B ir BQ serijų betonuose, turinčiuose daug cemento, gerokai padidèja medžiagos poringumas po degimo $1100{ }^{\circ} \mathrm{C}$ temperatūroje ir tai lemia charakteringą ir pakankamai ženklų betono gniuždymo stiprio verčių sumažèjimą.

Būdingas stiprumo sumažèjimas, siekiantis $\sim 35 \%$ B ir BQ serijų betonuose, paaiškinamas cemento mineralu rekristalizacijos procesu, kuris vyksta $800-1100{ }^{\circ} \mathrm{C}$ temperatūros intervale pagal schemą $\mathrm{C}_{12} \mathrm{~A}_{7} \rightarrow \mathrm{CA} \rightarrow \mathrm{CA}_{2}$ $\left(\mathrm{C}=\mathrm{CaO} ; \mathrm{A}=\mathrm{Al}_{2} \mathrm{O}_{3}\right)$ (Parr et al. 2004).

Dėl BOS 145 užpildo charakteristikų ir mažesnio vandens poreikio betono mišinyje, B4 betono bandiniai pasižymi $\sim 14 \%$ mažesniu atviru poringumu, $\sim 9 \%$ didesniu tankiu. Taip pat $\sim 50 \%$ didesniu gniuždymo stipriu lyginant su analogiškomis betono bandinių B2 ir B3 charakteristikomis (3.1 lentelè).

Panašios tendencijos išlieka ir papildomai naudojant $B Q$ betono kompozicijoje MKS priedą. Nustatyta, kad 2,5\% MKS priedo nežymiai padidina betono tankị ir jo gniuždymo stiprį, tuo atveju, kai betone panaudoti užpildai su mažesniu $\mathrm{Al}_{2} \mathrm{O}_{3}$ kiekiu (BQ2 ir BQ3). Tačiau BQ4 betono su BOS 145 užpildu analogiškų charakteristikų rodikliai nežymiai sumažejjo palyginus su B4 betono charakteristikomis (3.1 lentelè). 
Gerokai didesnè MKS priedo įtaka stebima analizuojant betono susitraukimo, atviro poringumo ir terminio atsparumo tyrimu rezultatus. Žinoma, kad dèl kvarco polimorfinių virsmų $573{ }^{\circ} \mathrm{C}$ temperatūroje vyksta šio mineralo plètimasis. Matyt dèl šio proceso MKS dalelès išsiplečia, ir todèl sumažèja betono poringumas (nuo 3,5 iki $11,7 \%$ ) po degimo $1100{ }^{\circ} \mathrm{C}$ temperatūroje (3.1 lentelè).

Nustatyta, kad B4 ir BQ4 betonų, su didžiausia $\mathrm{Al}_{2} \mathrm{O}_{3} / \mathrm{SiO}_{2}$ santykio verte lygia 0,89 , terminis atsparumas yra apie du kartus didesnis lyginant su analogiškais betonais, kurių santykio vertès yra 0,44 ir 0,68 (3.1 lentelè).

Vidutinio terminio atsparumo rodiklis, priklausomai nuo šamoto užpildo (B ir BQ grupès; 2.2 lentelè), tendencingai didèja (3.1 lentelè) didèjant $\mathrm{Al}_{2} \mathrm{O}_{3} / \mathrm{SiO}_{2}$ santykių vertems nuo $0,44 \mathrm{iki} 0,89$. Tai sutampa su anksčiau gautų tyrimų rezultatais, kad įtrūkių vystymuisi šamotinèse medžiagose veikiant terminiams smūgiams, turi įtakos jų cheminè sudètis (ypač kvarco ir tridimito kiekis), stiklo fazès ir ịvairių priemaišų kiekis, pagaminimo būdas ir temperatūra (Кащеев et al. 2007: 560-565). Taip pat šamotas, su mažu $\mathrm{Al}_{2} \mathrm{O}_{3} / \mathrm{SiO}_{2}$ santykiu, turi didesnes temperatūrines deformacijas palyginus su šamotu, kuriame yra didesnis $\mathrm{Al}_{2} \mathrm{O}_{3}$ kiekis ir mažesnis $\mathrm{SiO}_{2}$ kiekis (pvz. $65 \%$ $\mathrm{SiO}_{2}$ turintis šamotas $800{ }^{\circ} \mathrm{C}$ temperatūroje plečiasi $\sim 0,5 \% ; 53 \% \mathrm{SiO}_{2}-$ $\sim 0,25 \%$ ) (Šiaučiūnas et al. 1998: 95-96). Be to, BOS 145 užpilde yra ne tik mažiau kvarco, tridimito bei stiklo fazès, bet ir daugiau mulito, kurio ,adatine““ kristalų forma savotiškai armuoja medžiagą ir padidina jos mechanines ir terminio atsparumo charakteristikas (Aksel 2003).

3.12 paveiksle pateiktas betono bandinių charakteringas paviršiaus vaizdas po 6 terminių ciklų. Kaip matome iš šių tyrimų rezultatų, veikiant terminiams smūgiams, atsiranda destrukcijos požymiai, kurie iš dalies sutampa su terminio atsparumo rodiklio vidurkiais (3.1 lentelè). Galime pastebèti (3.12 a ir d pav.), kad ịtrūkiai yra didžiausi B2 kompozicijos bandiniuose $\left(\mathrm{Al}_{2} \mathrm{O}_{3} / \mathrm{SiO}_{2}-0,44\right)$, o mažiausi $\mathrm{B} 4$ kompozicijos bandiniuose $\left(\mathrm{Al}_{2} \mathrm{O}_{3} / \mathrm{SiO}_{2}-0,89\right)(3.12 \mathrm{c}$ ir f pav. $)$.

Lyginant betonų $\mathrm{B} 2$ su BQ2, B3 su BQ3, B4 su BQ4 termini atsparumą tarpusavyje, jis dèl MKS priedo $\sim 10-15 \%$ sumažeja ir tai nèra kritiška (3.1 lentelè).

Papildomi BQ serijos betonų deformacijų, veikiant apkrovai ir temperatūrai, tyrimai (3.13 pav.) parodè, kad deformacijos temperatūroms $\mathrm{T}_{0.5}$ (deformacijos pradžia) ir $\mathrm{T}_{5}$ (apibūdina betono maksimalią panaudojimo temperatūrą) turi ịtakos pakankamai žemas panaudoto betone AC40 cemento atsparumas ugniai, kuris siekia tik $\sim 1250{ }^{\circ} \mathrm{C}$ (žiūr. 2.1 poskyrị). Todèl deformacijos temperatūrų intervalas $\mathrm{T}_{5}\left(3.13\right.$ pav.) nežymus $\left(1270-1300{ }^{\circ} \mathrm{C}\right)$ ir mažai priklauso nuo panaudoto užpildo rūšies, kurio atsparumas ugniai siekia net $1690-1750{ }^{\circ} \mathrm{C}$. 


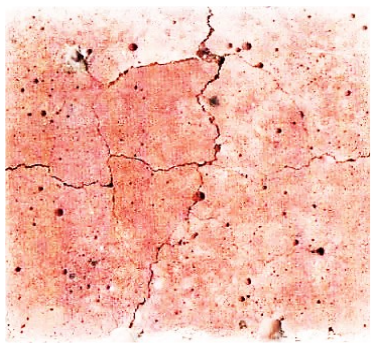

a)

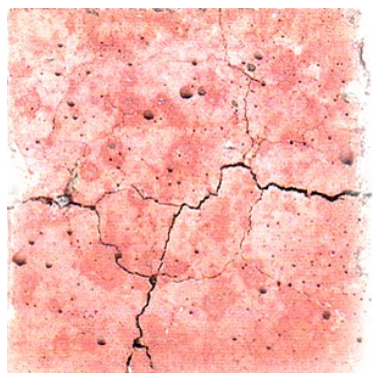

d)

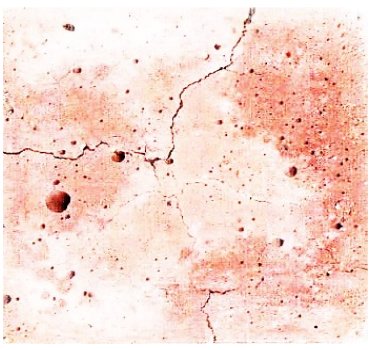

b)

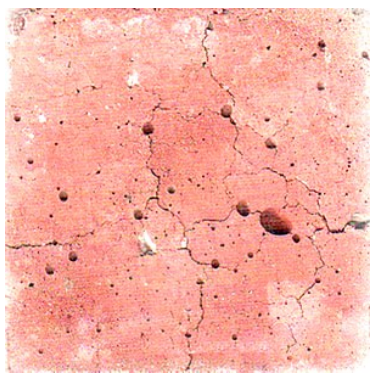

e)

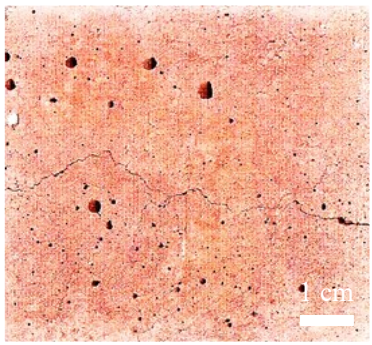

c)

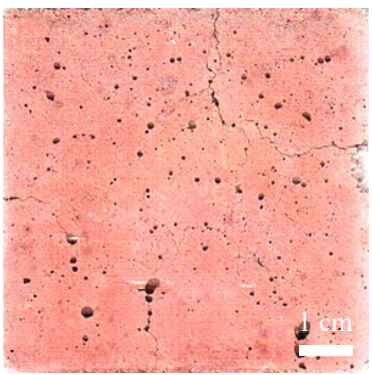

f)

3.12 pav. Betono bandiniu charakteringo paviršiaus vaizdas po 6 terminių ciklų: a) B2; b) B3; c) B4;
d) $\mathrm{BQ} 2$; e) $\mathrm{BQ} 3$; f) $\mathrm{BQ} 4$

Fig. 3.12. The view of the characteristic surface castable specimens after 6 thermal cycles: a) B2; b) B3; c) B4;

d) BQ2; e) BQ3; f) BQ4

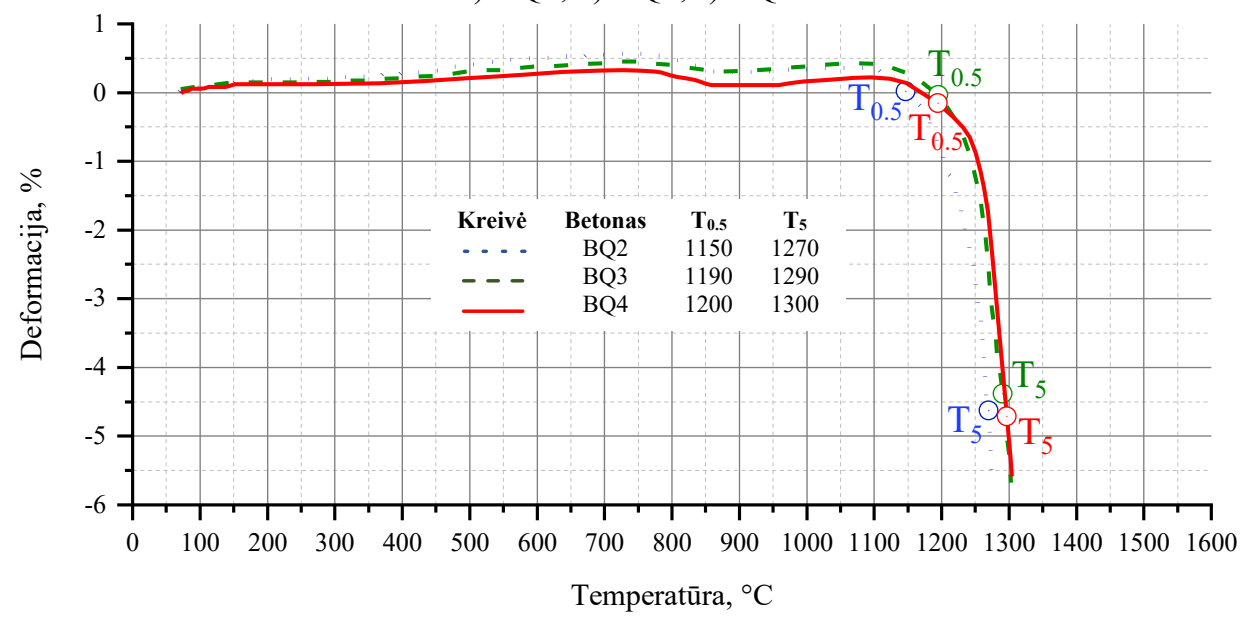

3.13 pav. BQ serijos betonų bandinių temperatūrinès deformacijos kreivès

Fig. 3.13. Temperature deformation curves of $B Q$ series castable samples 
Atlikti tyrimai parode, kad polikarboksilatinio deflokulianto ir $\mathrm{SiO}_{2}$ mikrodulkių priedų panaudojimas yra veiksminga priemonè įprastinio šamotinio betono matricos kokybès pagerinimui mažinant jos poringumą. Kita potenciali priemonè aliumosilikatinès medžiagos šarminiam atsparumui padidinti yra priedo, skatinančio atsparaus šarminiams junginiams barjero susiformavimą, panaudojimas. Tikètina, kad tokiu priedu galètų tarnauti MKS.

\subsubsection{Vidutinio cemento kiekio, ugniai atsparaus betono su skirtingais šamoto užpildais ir malto kvarcinio smèlio priedu, savybių tyrimai}

Vidutinio cemento kiekio ugniai atsparių betonų eksploatacinès savybès yra žymiai geresnès negu ịprastinių betonų, nežiūrint ị jų modifikavimą ultradispersiniais priedais (Antonovič et al. 2006; Pundienè et al. 2010). Reikia pabrèžti, kad yra mažesnis ir jų poringumas. Tokiu atveju galima tikètis geresnio VCB tipo cementinių betonų atsparumo šarminiam poveikiui naudojant MKS priedą, kuris, kaip buvo nustatyta (žiūr.1.6 poskyrị), skatinta apsauginio sluoksnio formavimąsi ugniai atsparaus betono struktūroje.

VCB serijos (2.3 lentelè) betono bandinių fizikinių, mechaninių ir terminių savybių tyrimų rezultatai pateikti 3.2 lenteleje. Galima pastebèti, kad VCB2 ir VCB3 betono bandinių, kuriuose buvo panaudoti BOS 125 ir BOS 135 markès šamoto užpildai, gautų savybių vidutiniai dydžiai atitinka panašias kitimo tendencijas, nustatytas ir modifikuotam iprastiniam betonui (3.1 lentelè), $\mathrm{Al}_{2} \mathrm{O}_{3} / \mathrm{SiO}_{2}$ santykio kitimo atžvilgiu.

Lygindami išdžiovintų ir išdegtų bandinių tankių rezultatus, (3.2 lentelè) matome, kad jie mažai skiriasi tarp VCB2 ir VCB3, tačiau $\sim 6 \%$ išauga VCB4 atveju.

VCB4 betonas su aukštesnès klasės BOS 145 markès šamoto užpildu yra tankesnis, pasižymi mažesniu poringumu ir jo gniuždymo stipris daugiau nei 1,5 karto yra didesnis negu VCB2 ir VCB3 betonų gniuždymo stipris (3.2 lentelè).

Reikia pabrěžti, kad poringumo rodiklis visais atvejais $\left(\mathrm{Al}_{2} \mathrm{O}_{3} / \mathrm{SiO}_{2}\right.$ santykis BOS 125 yra 0,44; BOS 135 yra 0,68; BOS 145 yra 0,89) padidejja pakèlus apdorojimo temperatūrą nuo $1100^{\circ} \mathrm{C}$ iki $1200{ }^{\circ} \mathrm{C}$ (3.2 lentelè).

Susitraukimo, kaip ir terminio atsparumo rodiklis, turi tendenciją didèti, didejant $\mathrm{Al}_{2} \mathrm{O}_{3} / \mathrm{SiO}_{2}$ santykiui. Pastebima, kad VCB serijos betono terminis atsparumas yra gerokai didesnis ir svyruoja 19-29 ciklų intervale (3.2 lentelè) palyginus su BQ serijos modifikuotu iprastiniu betono terminiu atsparumu, kuris svyruoja 8-17 ciklų (3.1 lentelè). 
3.2 lentelè. Vidutinio cemento kiekio betonų charakteristikos

Table 3.2. Characteristics of medium cement castables

\begin{tabular}{|c|c|c|c|}
\hline \multirow{2}{*}{ Charakteristika } & \multicolumn{3}{|c|}{ Betono sudèties žymuo } \\
\cline { 2 - 4 } & VCB2 & VCB3 & VCB4 \\
\hline Tankis, $\mathrm{kg} / \mathrm{m}^{3}:$ & & & \\
po džiovinimo $110^{\circ} \mathrm{C}$ & 2130 & 2130 & 2250 \\
po degimo $1100^{\circ} \mathrm{C}$ & 2080 & 2090 & 2210 \\
po degimo $1200{ }^{\circ} \mathrm{C}$ & 2080 & 2080 & 2200 \\
\hline Gniuždymo stipris, MPa: & & & \\
po džiovinimo $110^{\circ} \mathrm{C}$ & 47 & 55 & 109 \\
po degimo $1100^{\circ} \mathrm{C}$ & 66 & 76 & 126 \\
po degimo $1200{ }^{\circ} \mathrm{C}$ & 78 & 83 & 130 \\
\hline Poringumas, $\%:$ & & & \\
po degimo $1100^{\circ} \mathrm{C}$ & 20,9 & 20,3 & 19,1 \\
po degimo $1200^{\circ} \mathrm{C}$ & 21,3 & 21,4 & 20,2 \\
\hline Susitraukimas, $\%:$ & & & \\
po degimo $1100{ }^{\circ} \mathrm{C}$ & 0,25 & 0,28 & 0,28 \\
po degimo $1200^{\circ} \mathrm{C}$ & 0,11 & 0,14 & 0,25 \\
\hline Terminis atsparumas, ciklais & 19 & 24 & 29 \\
\hline
\end{tabular}

Pastaba: Atliktiems tyrimų rezultatams paskaičiuoti variacijos koeficientai yra: tankiui $0,56 \%$; gniuždymo stipriui $4,34 \%$; terminiam atsparumui $2,96 \%$ ir poringumui $4,95 \%$.

Taip pat reikia pažymèti, kad VCB serijos gniuždymo stiprio rodiklis, palyginus su BQ serijos betonais, yra didesnis 43-88\%. Tai siejama $\mathrm{su}^{\mathrm{SiO}_{2}}$ mikrodulkių ir reaktyvaus ar kalcinuoto aliuminio oksido panaudojimu šios serijos betono sudètyje (2.3 lentelè). Sistemoje su $\mathrm{CaO}$ (kai naudojamas sumažintas kalcio aliuminatinio cemento kiekis betone) pastarieji priedai $800-1100{ }^{\circ} \mathrm{C}$ temperatūroje reaguoja, susidarant $C A, C A_{2}$, anortitui ir gelenitui (Martinovic et al. 2009; Firoozjaei et al. 2010).

Deformacijų temperatūrų, veikiant apkrovai, tyrimų rezultatai rodo (3.14 pav.), kad VCB betonu kritinè temperatūrinè deformacija $\left(\mathrm{T}_{5}\right)$ atsiranda gerokai didesneje temperatūroje negu $\mathrm{BQ}$ serijos betonuose (3.13 pav.). Šioje serijoje $\mathrm{T}_{5}$ - temperatūra, priklausomai nuo šamoto užpildo, siekia $1390-1480{ }^{\circ} \mathrm{C}$ (tai $110-180^{\circ} \mathrm{C}$ daugiau nei iprastinio modifikuoto betono atveju). Toks padidejimas susijęs su tuo, kad VCB betone naudojamas aukštatemperatūris cementas AC70, kurio atsparumas ugniai yra $>1630^{\circ} \mathrm{C}$. Tokia temperatūra yra charakteringa ir šamoto užpildams (2.1 lentelè; atsparumas ugniai). Panaši ir rodiklio $\mathrm{T}_{0.5}$ (deformacijos pradžia) kitimo tendencija, kuri palyginus VCB serijos su $\mathrm{BQ}$ serijos betonais padideja nuo $50{ }^{\circ} \mathrm{C}$ iki $120{ }^{\circ} \mathrm{C}$ (kai yra panaudotas tos pačios markès šamotas betone). 


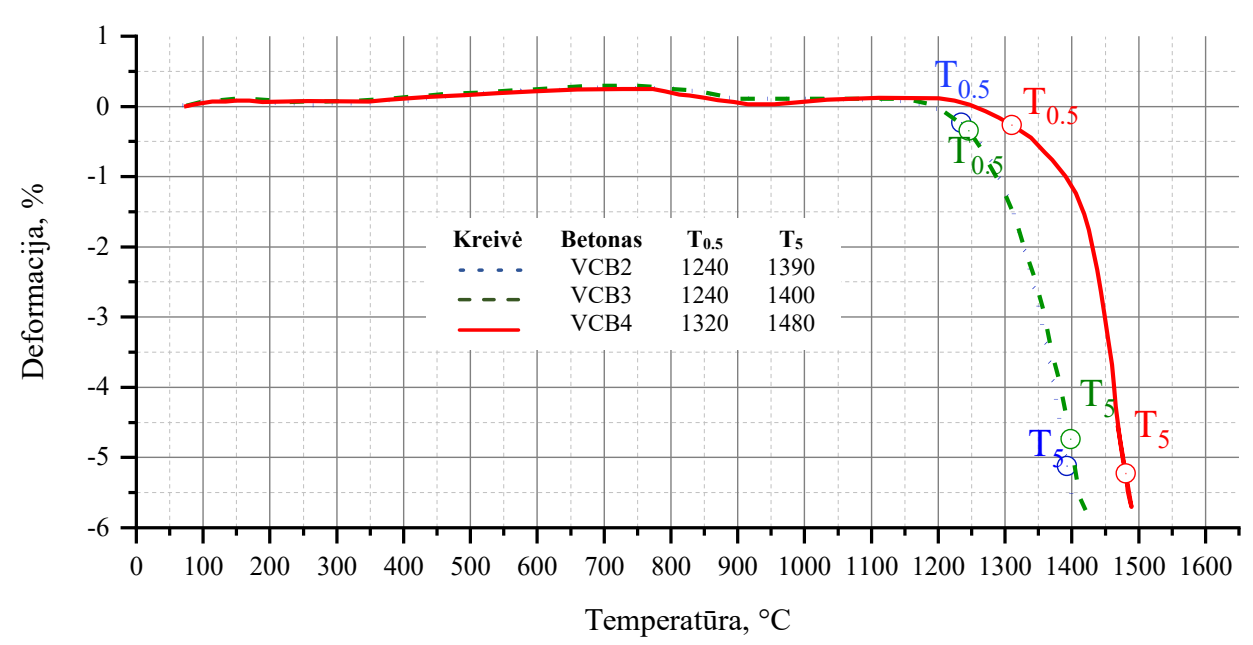

3.14 pav. VCB serijos betono bandinių temperatūrinès deformacijos kreivès Fig. 3.14. Temperature deformation curves of VCB series castable samples

Atlikti tyrimai parode, kad VCB serijos eksploatacinių savybių rodiklių gerejjimo tendencija (tankio, gniuždymo stiprio, terminio atsparumo, deformacijos temperatūros rodiklių padidejjimas, o poringumo sumažèjimas) priklauso nuo panaudoto užpildo ir siejama su $\mathrm{Al}_{2} \mathrm{O}_{3} / \mathrm{SiO}_{2}$ santykio padidejjimu jame $(\operatorname{BOS} 125=0,44$; BOS $135=0,68$; $\operatorname{BOS} 145=0,89)$.

\subsubsection{Staigaus kaitinimo ir aušinimo poveikis vidutinio cemento kiekio betono destrukcijai}

Ugniai atsparių medžiagų savybė išlaikyti savo pradinę būseną (nesuirti) temperatūrinių svyravimų poveikyje ir kaitinant, ir atvėsinant yra vadinama atsparumu ugniai (Šiaučiūnas et al. 1998). Procesai, kurie lemia medžiagos suirimą, dèl mažo atsparumo ugniai, sąlygoja ir medžiagoje atsirandančius ịtempius. Maksimalių įtempių dydis $\left(\sigma_{\max }\right)$ yra tiesiai proporcingas temperatūriniam išsiplètimo koeficientui $(\alpha)$, tamprumo moduliui $(E)$ ir temperatūrų skirtumui $\left(\Delta T=T_{0}-T_{l}\right)$, bet atvirkščiai proporcingas $1-(\mu)$ Puasono koeficientui, charakterizuojančiam kūno vidinę energiją:

$$
\sigma_{\max }=\frac{E \alpha}{1-\mu} \Delta T
$$

čia: $\sigma_{\max }$-maksimalių ittempių dydis; $E$-Jungo modulis; $\alpha$-temperatūrinis išsiplètimo koeficientas; $\Delta T$ - temperatūrų skirtumas; $\mu$ - Puasono koeficientas. 
Medžiagos suirimo atveju, maksimalių įtempių dydis turi viršyti medžiagos stiprumą. Būtent terminiai ịtempiai $(R)$ yra dviejų rūšių: pirmos rūšies $\left(R^{I}\right)$, kuriuos sukelia temperatūrinis gradientas ir antros rūšies $\left(R^{I I}\right)$, kurie sąlygoja temperatūrinio gradiento anizotropiją dèl šiluminio išsiplètimo koeficiento arba dèl cheminių reakcijų vyksmo bei medžiagos polimorfizmo atvejais. Pastarieji vyksta ir esant pastoviai temperatūrai, susietai medžiagų chemine sudètimi. Abiem atvejais ịtempiai kyla tada, kai medžiaga praranda laisvą galimybę keisti savo tūrị dèl vienokių arba kitokių priežasčių. Labiausiai ištyrinètas pirmos rūšies ịtempių pasireiškimo mechanizmas. Kaitinant ugniai atsparią medžiagą, paviršiniai (išoriniai) jos sluoksniai ịkaista ir plečiasi labiau nei vidiniai. Tokiu atveju ịtempiai kyla dèl medžiagos pasipriešinimo keisti savo matmenis, kadangi kietas kūnas kaitinant plečiasi. Tuo tarpu atvėsinant (atšaldant) pasireiškia priešingos krypties (traukimosi) įtempiai (Кащеев et al. 2007).

Pirmos rūšies ịtempiai priklauso nuo medžiagos šilumos perdavimo koeficiento (h), kieto kūno šilumos laidumo koeficiento $\left(\lambda_{s}\right)$, atstumo tarp medžiagos paviršiaus ir kieto kūno arba būdingojo matmens $\left(l_{s}\right)$, susieto su bedimensiniu Bio kriterijumi taip (Сена 1977; Barkauskas et al. 1997; Кащеев et al. 2007; Novošinskas 2012):

$$
B i=\frac{h \cdot l}{\lambda},
$$

čia: $h$ - šilumos perdavimo koeficientas $\mathrm{W} /\left(\mathrm{m}^{2} \cdot \mathrm{K}\right) ; l$-kieto kūno būdingasis matmuo; $\lambda$ - kieto kūno šilumos laidumo koeficientas $\mathrm{W} /(\mathrm{m} \cdot \mathrm{K})$.

Taip pat priklauso nuo medžiagos trapumo parametro $\chi$ (tamprios medžiagos suirimo atveju) arba plastiškumo rodiklio (pusiau plastiško suirimo atveju), temperatūros kilimo arba atvésinimo greičio ir t.t. (Кащеев et al. 2007).

Itempiai, sukeliantys ugniai atsparių medžiagų suirimą, paprastai aprašomi tokia lygtimi:

$$
R=\sigma_{s}(1-\mu) /(E \alpha),
$$

čia: $R$ - atsparumo ugniai kriterijus (kuo didesnè verté, tuo didesnis atsparumas ugniai); $\sigma_{s}$ - medžiagos stiprumas (lenkimo stipris, gniuždant arba spaudžiant); $\mu$ - Puasono koeficientas; $E$ - Jungo modulis; $\alpha$ - temperatūrinis išsiplètimo koeficientas.

Atsparumo ugniai kriterijai yra išreiškiami šiomis lygtimis (Кащеев et al. 2007):

$$
\begin{aligned}
& R^{I}=R \lambda, \\
& R^{I I}=R \alpha,
\end{aligned}
$$


čia: $R, R^{I}, R^{I I}$ - atitinkami atsparumo ugniai kriterijai.

Reikia pažymèti, kad šiandien egzistuoja daug atskirų terminio ardymo mechanizmų teorinių pagrindimų (pvz. kaip: „Trapių kūnų suirimo, kai ịtempiai maksimalūs“; „Dviejų stadijų“; „Struktūrinė arba fragmentine““; „Statistinè arba silpnojo nario“; ,Nuovargio“; „Relaksacijos“; „Terminio senėjimo“; „Antros rūšies itempiu““ ir kitos teorijos) (Кащеев et al. 2007). Atkreiptinas demesys, kad šiuolaikiniame pasaulio mokslinio pažinimo etape dar nėra sukurtos vieningos ugniai atsparių dirbinių suirimų teorijos, kadangi tokių medžiagų nepastoviose ir greitai besikeičiančiose eksploatacijos sąlygose vykstantys suirimo procesai yra labai sudètingi, sunkiai įvertinami ir aprašomi.

3.3 lentelëje pateiktos tiriamų betonų svarbiausios savybès, kurios turètų leisti numatyti jų atsparumą ugniai. Matoma, kad vidutinio cemento kiekio betono serijos bandiniai su fibra yra didesnio vidutinio tankio, tačiau MCB betonas yra didžiausio tankio. Ultragarso impulso greitis ir tankis buvo reikalingas apskaičiuoti prognozuojamam Jungo moduliui (2.2 formulè), kurio vertès pateiktos žemiau. Taip pat pagal ultragarso greičio pokytị $(\Delta \mathrm{UV})$ buvo vertinamas ugniai atsparių bandinių destrukcijos procesas atliekant ciklinius ilgalaikius bandymus.

3.3 lentelè. Betonų fizikinès ir mechaninès charakteristikos po degimo $900{ }^{\circ} \mathrm{C}$ temperatūroje Table 3.3. Physical and mechanical characteristics of castable after combustion at $900{ }^{\circ} \mathrm{C}$

\begin{tabular}{|c|c|c|c|c|c|c|}
\hline \multirow{2}{*}{\multicolumn{2}{|c|}{ Charakteristika }} & \multicolumn{5}{|c|}{ Betono žymuo } \\
\hline & & VCB3 & VCB3-F & VCB4 & VCB4-F & MCB \\
\hline \multicolumn{2}{|l|}{ Tankis, $\mathrm{kg} / \mathrm{m}^{3}$} & 2120 & 2160 & 2250 & 2290 & 2350 \\
\hline \multicolumn{2}{|c|}{ Ultragarso impulso greitis, $\mathrm{m} / \mathrm{s}$} & 3540 & 3650 & 4140 & 4050 & 5050 \\
\hline \multicolumn{2}{|c|}{ Jungo modulis, $\mathrm{GPa}$} & 16,0 & 17,3 & 23,2 & 22,6 & 36,1 \\
\hline \multicolumn{2}{|c|}{ Gniuždymo stipris, MPa } & 78,1 & 80,9 & 105,9 & 111,8 & 118,3 \\
\hline \multicolumn{2}{|c|}{ Lenkimo stipris, $\mathrm{MPa}$} & 9,6 & 12,0 & 13,5 & 14,5 & 19,7 \\
\hline \multicolumn{2}{|c|}{$\begin{array}{l}\text { Šiluminio plètimosi koeficientas } \\
\left(10^{-6}{ }^{\circ} \mathrm{C}^{-1}\right)\end{array}$} & 0,66 & 0,66 & 0,66 & 0,66 & 0,68 \\
\hline \multirow{3}{*}{$\begin{array}{l}\text { Ultragarso greičio } \\
\text { pokytis }(\Delta U V, \%)\end{array}$} & po 1 ciklo & 5,6 & 2,2 & 5,5 & 3,3 & 8,0 \\
\hline & po 3 ciklų & 5,7 & 3,4 & 6,4 & 5,0 & 21,3 \\
\hline & po 7 ciklų & 6,8 & 4,5 & 8,7 & 6,2 & - \\
\hline
\end{tabular}

Pastaba: Atliktiems tyrimu rezultatams paskaičiuoti variacijos koeficientai yra: tankiui $0,6 \%$; ultragarso impulso greičiui $1,2 \%$; gniuždymo stipriui $3,5 \%$; lenkimo stipriui $4,1 \%$; šlumos plètimosi koeficientui $1,8 \%$; ultragarso greičio pokytis $\Delta \mathrm{UV}_{1}-1,3 \% ; \Delta \mathrm{UV}_{3}-1,1 \% ; \Delta \mathrm{UV}_{7}-1,1 \%$.

Iš ištirtų bandinių matyti, jog minimali ultragarso impulso greičio vidutinè vertè būdinga kaip ir prognozuojamam Jungo moduliui VCB3, o maksimali 
MCB betonui. Gniuždomojo ir lenkiamojo stiprio vidutinès vertès auga pagal seką VCB3 $\rightarrow \mathrm{VCB} 3-\mathrm{F} \rightarrow \mathrm{VCB} 4 \rightarrow \mathrm{VCB} 4-\mathrm{F} \rightarrow \mathrm{MCB}$. Tuo tarpu šilumos plètimosi koeficiento vidutinès vertès yra tapačios VCB betonams, išskyrus MCB betoną.

Būtina akcentuoti ultragarso greičio pokyčio verčiu kitimo tendencijas minètiems vidutinio cemento kiekio betonams. Vienareikšmiškai fiksuojama, jog betonai su fibros intarpais yra labiau atsparesni cikliniam destrukcijos procesui. $1 \%$ metalinès fibros priedas pastebimai sulètina VCB serijos betonų destrukciją. Tai, kad skirtingo tipo fibra sumažina ịtrūkių vystymąsi, pažymi ir (Соков 2015; Da Luz et al. 2015) darbų autoriai.

Tuo tarpu komercinio MCB betono bandiniuose suirimai atsiranda jau po dviejų - trijų ciklų (3.15 pav.). Tęsiant bandymą (4-to ciklo kaitinimo metu) visi komercinio betono bandiniai per atsiradusius (po 2 ar 3 ciklų) įtrūkius suskilo ị gabalus. Todèl, kai tokio betono bandinys yra staigiai kaitinamas-aušinamas jame susidaro kritiniai terminiai įtempiai, dèl kurių bandinys ir skyla.

Šiluminių ịrenginių stabdymo ar paleidimo metu monolitinès išklojos iš ugniai atsparių betonų (praejus pirmojo džiovinimo ir kaitinimo procedūrai) negali būti aušinamos arba kaitinamos didesniu nei $50{ }^{\circ} \mathrm{C} /$ val. greičiu. Keliant arba mažinant temperatūrą didesniu greičiu, didèja medžiagos skilimo pavojus dèl temperatūrinio gradiento ir kritinių ịtempių atsiradimo (Zabolotsky 2011). Kieto biokuro irenginiai dažnai stabdomi pelenų valymui, todèl atsiranda poreikis greitesniam išklojos ịvedimui ị eksploataciją, kai temperatūros kẻlimo greitis didesnis nei $100^{\circ} \mathrm{C} / \mathrm{val}$.

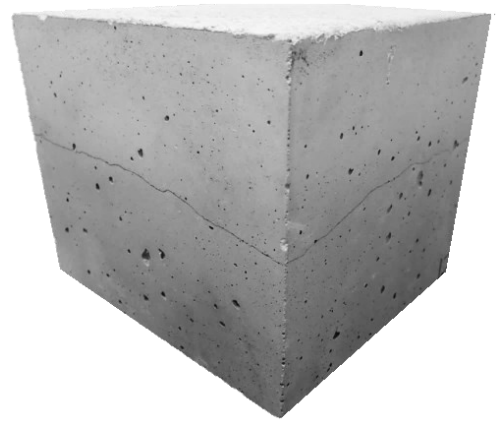

3.15 pav. MCB betono bandinio vaizdas po $2-3$ kaitinimo ir aušinimo ciklų

Fig. 3.15. MCB castable samples after $2-3$ heating and cooling cycles 
Atlikti tyrimai parodè, $\mathrm{kad} 300{ }^{\circ} \mathrm{C} /$ val. greičiu keliant temperatūrą iki $900{ }^{\circ} \mathrm{C}$ ir vèliau $\sim 400{ }^{\circ} \mathrm{C} /$ val. aušinant skirtingo tipo ugniai atsparaus betono su šamoto užpildais bandinius, VCB serijos betono bandiniai atlaikè net 10 ciklų be vizualiai pastebimų pažeidimų, o MCB betono bandiniai suskilo jau po $2-3$ kaitinimo aušinimo ciklų.

Taip pat nustatyta, kad $1 \%$ metalinès fibros priedas sumažino VCB serijos betonų su BOS 135 ir BOS 145 užpildu destrukciją pagal ultragarso greičio pokytị cikliškai kaitinant $300{ }^{\circ} \mathrm{C} /$ val. ir aušinant $\sim 400{ }^{\circ} \mathrm{C} /$ val. greičiu.

\subsection{Betono šarminio atsparumo tyrimai ir jų vertinimas}

Vienas iš pagrindinių darbo tikslų, atliekant standartinius tyrimus tiglio metodu, yra maksimaliai objektyviai charakterizuoti ir ịvertinti įvairaus ugniai atsparaus betono šarminį atsparumą ciklinio poveikio metu. Kaip aukščiau buvo išdèstyta (2.2 poskyris), po kiekvieno ciklo betono bandinio ertmè yra užpildoma vienodu kiekiu kalio karbonato druskos. Toliau bandinys kaitinamas krosnyje $1100{ }^{\circ} \mathrm{C}$ arba $1200^{\circ} \mathrm{C}$ temperatūroje išlaikant joje 5 valandas, o po to aušinamas iki kambario $20^{\circ} \mathrm{C}$ temperatūros ir apžiūrimas siekiant vizualiai nustatyti irimo požymius. Tuo vienas ciklas laikomas baigtu.

\subsubsection{Modifikuoto betono šarminis atsparumas}

Kaip matome iš 3.16 paveikslo, jau po pirmo šarminio atsparumo ciklo B serijos betono bandiniuose be MKS priedo, atsirado $>0,4 \mathrm{~mm}$ pločio ịtrūkiai. Naudojamas tyrimams reagentas $\mathrm{K}_{2} \mathrm{CO}_{3}$ lydosi temperatūroje $891{ }^{\circ} \mathrm{C}$ ir lengvai ìsigeria ì poringą (atviras poringumas 23,0-27,2\%, 3.1 lentelè) šios serijos šamotinio betono struktūrą (difunduoja ị šamoto poras ir kapiliarus sukeldamas mikroịtrūkius) (3.16 pav. d, e, f).

Vykdant tolimesnį bandinių ciklinį poveikị $\mathrm{K}_{2} \mathrm{CO}_{3}$, palaipsniui tęsiasi ir po pirmo ciklo atsiradusių įtrūkių vystymasis. Po 4 bandymo ciklų (3.17 pav.) stebime plyšių didejjimą bandiniuose iki $\sim 3-5 \mathrm{~mm}$. Analogiški suirimų atvejai pateikti Poirier (Poirier et al. 2017 a:12-13) darbe.

Reikia pažymèti, kad B4 betono bandiniuose makroịtrūkių plotis yra šiek tiek mažesnis negu B2, B3 betono bandiniuose (palyginti 3.17 pav. c su a, b). 


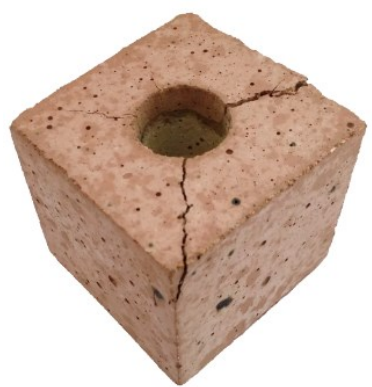

a)

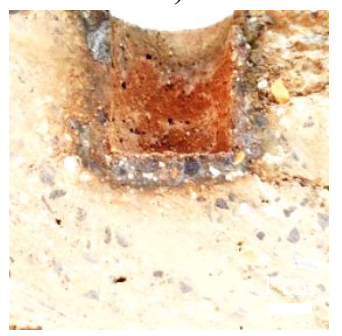

d)

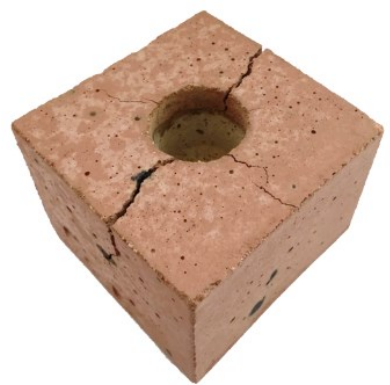

b)

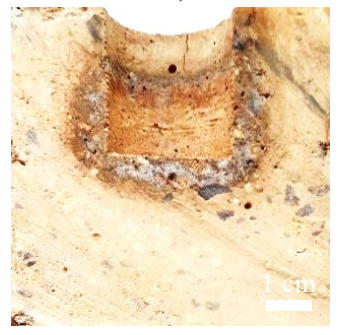

e)

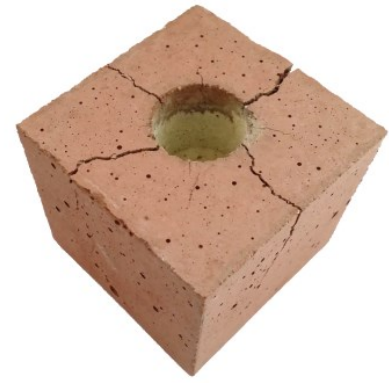

c)

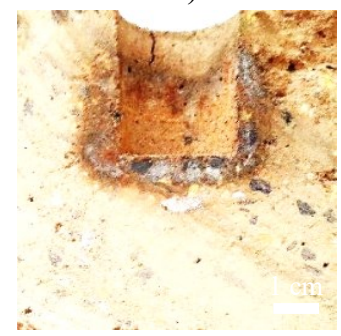

f)

3.16 pav. $B$ serijos betono bandinių bendras $(a, b, c)$ ir skerspjūvio (d, e, f) vaizdas po 1 šarminio atsparumo bandymo ciklo: a, d - betonas B2; b, e - B3; c, f-B4

Fig. 3.16. General view (a, b, c) and cross sections (d, e, f) of B series castable samples after 1 cycle of alkali resistance test: a, d-castable B2; b, e-B3; c, f-B4

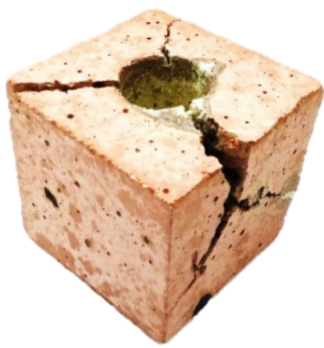

a)

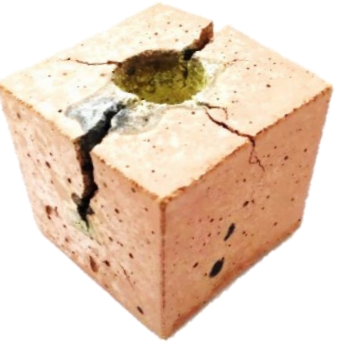

b)

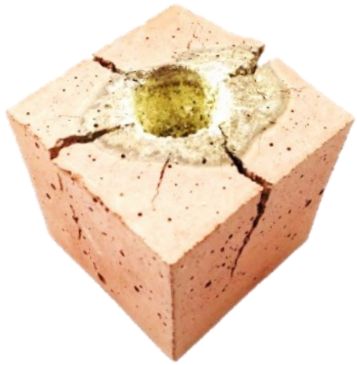

c)

3.17 pav. B serijos betono bandinių vaizdas po 4 šarminio atsparumo bandymo ciklų: $\mathrm{a}$ - betonas $\mathrm{B} 2$; $\mathrm{b}-\mathrm{B} 3$; $\mathrm{c}-\mathrm{B} 4$

Fig. 3.17. General view $B$ series castable samples after 4 cycles of alkali resistance test: $\mathrm{a}$ - castable B2; b-B3; c-B4 


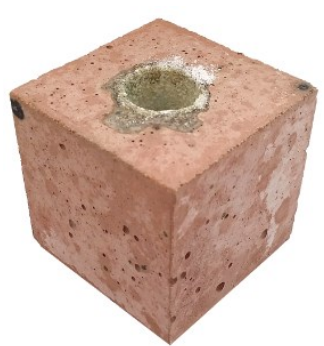

a)

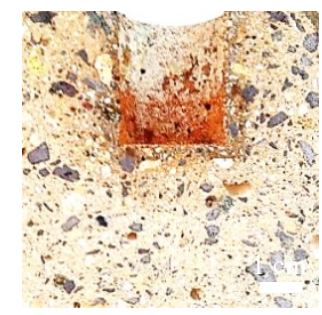

d)

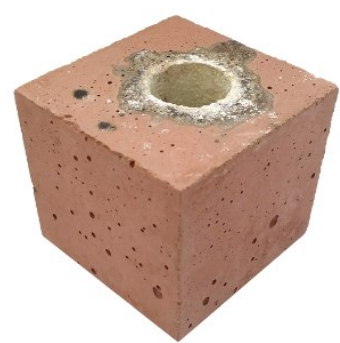

b)

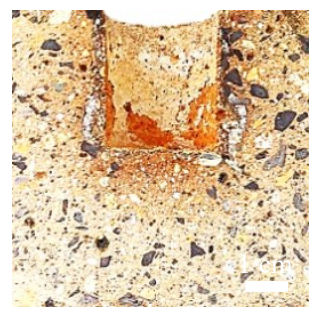

e)

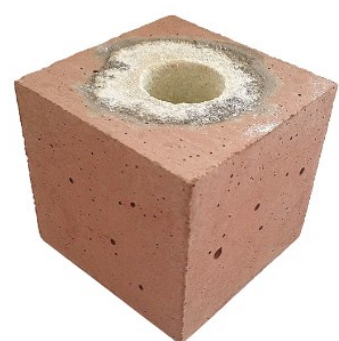

c)

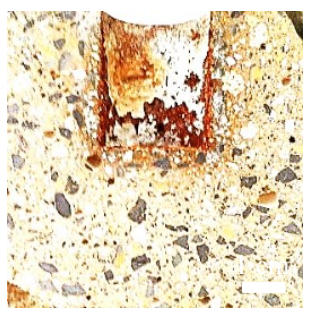

f)

3.18 pav. BQ serijos betono bandinių bendras $(a, b, c)$ ir skerspjūvio (d, e, f) vaizdas po 1 šarminio atsparumo bandymo ciklo: $\mathrm{a}, \mathrm{d}$ - betonas BQ2; b, e - BQ3; c, f-BQ4 Fig. 3.18. General view (a, b, c) and cross sections (d, e, f) of $B$ series castable samples after 1 cycle of alkali resistance test: a, d-castable BQ2; b, e-BQ3; c, f-BQ4

Kaip matyti iš (3.18 pav.) BQ serijos, betono bandiniai, kurie yra modifikuoti MKS priedu, po vieno bandymo ciklo visai neturi jokių matomų defektų palyginus su (3.18 pav.) B serijos betonu, kuriame jau po pirmo ciklo fiksuojami įtrūkiai.

Tolesni BQ serijos betono bandinių tyrimų (kaitinant prie $1100{ }^{\circ} \mathrm{C}$ temperatūros) rezultatai pateikti (3.19 pav.).

Kaip matyti iš šių tyrimų rezultatų po 6 ciklų (3.19 a, b, c), bandinių paviršiaus viršutinėse zonose atsiranda pavieniai mikroịtrūkiai. Tai galima paaiškinti vienu metu vykstančiais procesais: kalio karbonato skilimu ir $\mathrm{CO}_{2}$ išsiskyrimu, jo skvarba (difuzija), lydalo susidarymu porose ir kapiliaruose iš labiausiai linkusių lydytis junginių (pvz. stiklo fazès). Tuo pat metu sistemoje išsivysto slègis dèl $\mathrm{CO}_{2}$ skilimo bei difuzijos proceso porų kapiliarų sistemoje ir vykstančių cheminių reakcijų poveikio, kuris sukelia bandinių destrukciją (suirimą). Tolygiai didinant ciklų skaičių, tolygiai didèja ir užkraunamo reagento $\left(\mathrm{K}_{2} \mathrm{CO}_{3}\right)$ kiekis. Priklausomai nuo ugniai atsparaus betono porų ir kapiliarų struktūros (kurią iš dalies galima įvertinti poringumo rodikliu), ciklinio bandymo metu potencialiai vis giliau i bandini skverbiasi nauji besilydančio ir skylančio reagento kiekiai. Tokiu atveju plečiasi reakcijos zona ir auga besivystantys slègiai, kurie vysto deformacijas ir ittempius bei ardo ugniai 
atsparios medžiagos struktūrą. Šie procesai vyksta modelinių bandymų metu ir eksploatuojant išklojas biokuro energetiniuose ịrenginiuose. Pastebeta, kad esant ypač palankiai ugniai atsparaus betono sandarai ir struktūrai, kai modelinio bandymo metu veikiant kalio karbonatui $\left(\mathrm{K}_{2} \mathrm{CO}_{3}\right)$ gali susidaryti paviršinio barjero sluoksnis, uždarantis poras ir kapiliarus, tokiu atveju kalio karbonatas skyla, putoja ir veržiasi ant bandinių paviršiaus net i jị neịsigerdamas. Teoriškai toks sluoksnis galètų susidaryti ir ekstremaliomis eksploatacinėmis sąlygomis degant medžiagoms, kurios turi kalio ar natrio junginių.

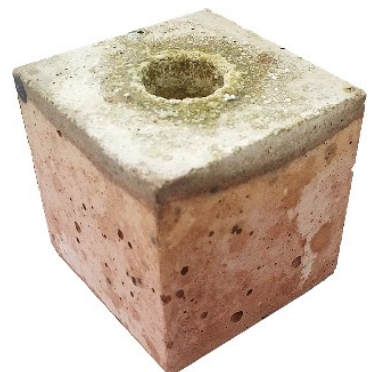

a)

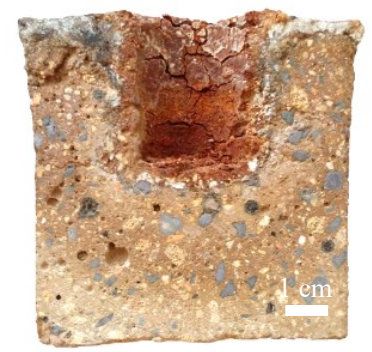

d)

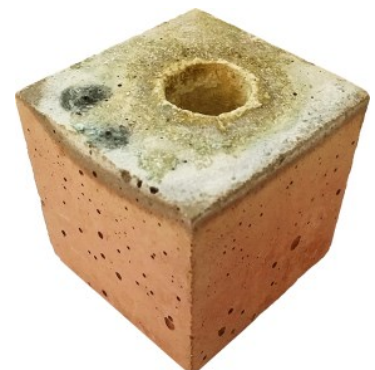

b)

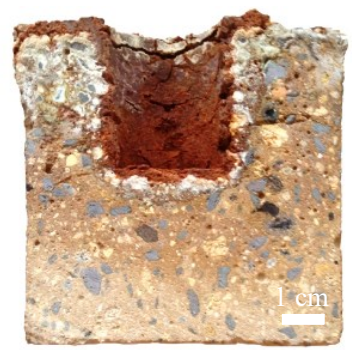

e)

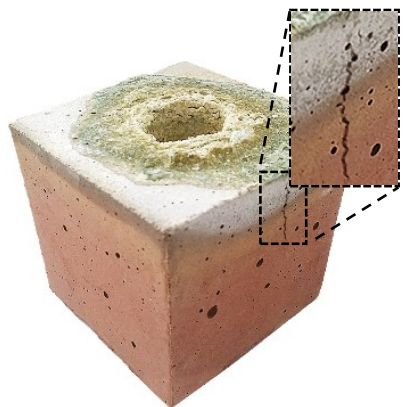

c)

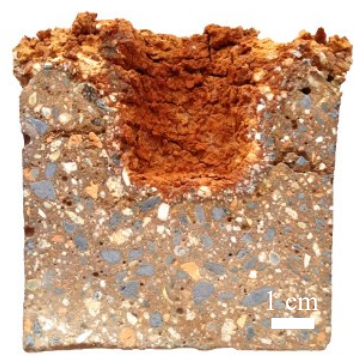

f)

3.19 pav. BQ serijos betono bandinių bendras vaizdas po 6 ciklų $(a, b, c)$ ir skerspjūvio $(\mathrm{d}, \mathrm{e}, \mathrm{f})$ vaizdas po 20 šarminio atsparumo bandymo ciklų: a, $\mathrm{d}$ - betonas $\mathrm{BQ} 2$; $\mathrm{b}, \mathrm{e}-\mathrm{BQ} 3$; $\mathrm{c}, \mathrm{f}-\mathrm{BQ} 4$;

Fig. 3.19. General view of $B Q$ series castable samples after 6 cycles $(a, b, c)$ and view of cross sections $(\mathrm{d}, \mathrm{e}, \mathrm{f})$ after 20 cycles of alkali resistance test: a, d- castable BQ2; b, e-BQ3; c, f-BQ4;

BQ serijos betono atveju aukštoje temperatūroje paveiktam betonui kontaktuojant su kalio karbonatu susidaro nepralaidaus barjero sluoksnis. Tokiu atveju bandiniai po 20 ciklų išlieka praktiškai nepakitusios betono mikrostruktūros (3.19 pav. d, e, f). 


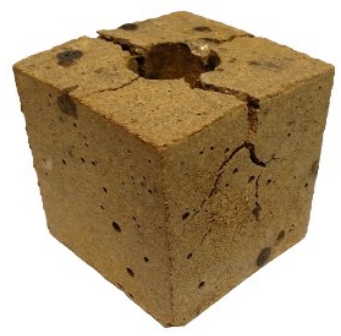

a)

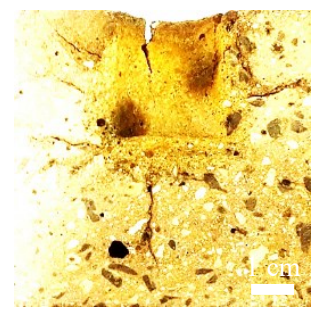

d)

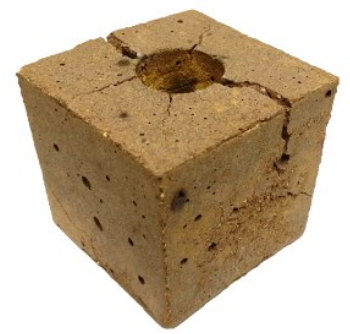

b)

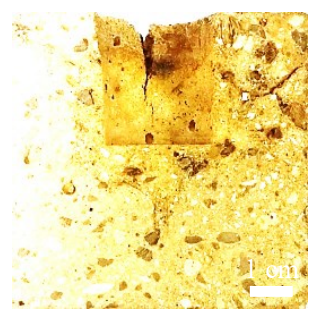

e)

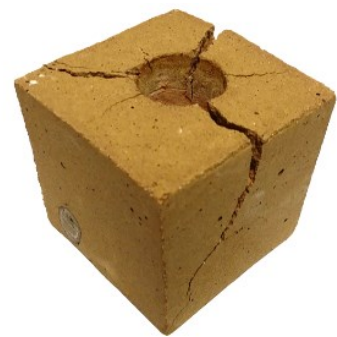

c)

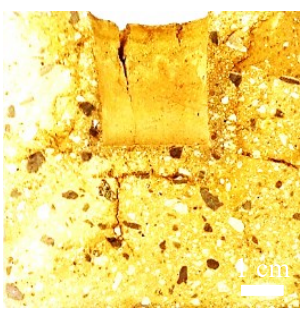

f)

3.20 pav. BQ serijos betono bandinių bendras $(a, b, c)$ ir skerspjūvio $(d, e, f)$ vaizdas po 1 šarminio atsparumo bandymo ciklo $1200^{\circ} \mathrm{C}$ temperatūroje: $\mathrm{a}, \mathrm{d}$ - betonas $\mathrm{BQ} 2$;

$$
\text { b, e-BQ3; c, f-BQ4 }
$$

Fig. 3.20. General $(a, b, c)$ and cross section $(d, e, f)$ view of $B Q$ series castable samples after 1 cycle of alkali resistance test at $1200{ }^{\circ} \mathrm{C}$ temperature: a, $\mathrm{d}$ - castable BQ2;

$$
\mathrm{b}, \mathrm{e}-\mathrm{BQ} 3 ; \mathrm{c}, \mathrm{f}-\mathrm{BQ} 4
$$

Kai BQ serijos betono šarminis atsparumas buvo tiriamas esant $1200{ }^{\circ} \mathrm{C}$ temperatūrai, pastebèta, kad visų sudéčių tokio betono bandiniai suskilo jau po pirmo ciklo (3.20 pav.). Po dviejų ciklų bandiniai visiškai suiro ị gabalus. Tai reiškia, kad $1200{ }^{\circ} \mathrm{C}$ temperatūroje apsauginis barjeras ịprastiniame betone su kvarcinio smėlio priedu nesusidaro. Šarminio lydalo skverbimąsi ị medžiagą galima paaiškinti iprastinio betono poringumo parametru pakitimu. Nustatyta (3.1 lentelè), kad keliant kaitinimo temperatūrą nuo $1100{ }^{\circ} \mathrm{C}$ iki $1200^{\circ} \mathrm{C}$ atviras poringumas padidèja iki $8 \%$ (siekia $\sim 23-26 \%$ ).

Degant medienos kurui, katilo pakuros maksimali eksploatacijos temperatūra dažniausiai neviršija $1100{ }^{\circ} \mathrm{C}$, todèl modifikuoti įprastiniai betonai su MKS priedu gali būti naudojami katilų išklojų ìrengimui. Pastebèta, kad jie negali būti naudojami pakuros zonose, kuriose yra tiekiamas antrinis oras ir lokalinès temperatūros pasiekia $1200{ }^{\circ} \mathrm{C}$ temperatūrą bei gali susidaryti šarminis lydalas.

Katilu gamintojams rekomenduojama (Klinger et al. 2007) išdėstyti temperatūrinius jutiklius pakuroje taip, kad šie reaguotų i įrenginio zonų lokalinius temperatūrinius svyravimus, užtikrinandami eksploatacijos temperatūros stabilumą, kuris eliminuotų lydalo susidarymo galimybes. 


\subsubsection{Modifikuoto vidutinio cemento kiekio betono šarminis atsparumas}

Vidutinio cemento kiekio betono savybės yra geresnès negu ịprastinio betono, (aptarta 3.2.2 poskyryje). Reikia taip pat pažymèti, kad ir atviras poringumas tokio tipo betonų yra mažesnis nei ịprastinio betono (3.1 ir 3.2 lentelè).

Standartiniai modifikuoto betono su sumažintu cemento kiekiu šarminio atsparumo tyrimo rezultatai po 3 ciklų pateikti žemiau. Iš pateiktų pjūvių galime konstatuoti, jog nèra vizualiai pastebimų VCB serijos betono mikrostruktūros suirimo (po 3 ciklų) požymių (3.21 pav.).

Reikia pažymèti, kad visi VCB serijos betono bandiniai $1100{ }^{\circ} \mathrm{C}$ temperatūroje išlaikė 20 ciklų be ženklaus bandinių irimo.

Atlikus tolimesnius VCB serijos betono tyrimus $1200^{\circ} \mathrm{C}$ temperatūroje, visų minètų betonų bandiniai išlaikè 6 ciklus be jokių mikroịtrūkių kaip bandinių paviršiuje, taip ir jų pačios struktūros pjūvio vietose (3.22 pav.).

Gauti VCB serijos šarminio atsparumo tyrimo rezultatai rodo, kad visuose betono bandiniuose, nepriklausomai nuo $\mathrm{Al}_{2} \mathrm{O}_{3} / \mathrm{SiO}_{2}$ santykio šamoto užpilde, nèra $\mathrm{K}_{2} \mathrm{CO}_{3}$ skilimo produktų skverbimosi į medžiagų struktūrą nei po $1100{ }^{\circ} \mathrm{C}$, nei po $1200{ }^{\circ} \mathrm{C}$ temperatūrų. Tai reiškia, kad bandinių paviršiuje susiformavęs apsauginis barjeras yra stabilus $1100^{\circ} \mathrm{C}$ ir $1200{ }^{\circ} \mathrm{C}$ temperatūroje.

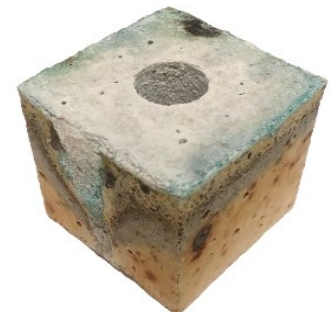

a)

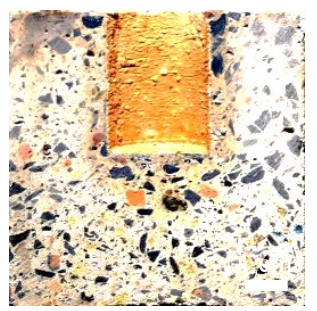

d)

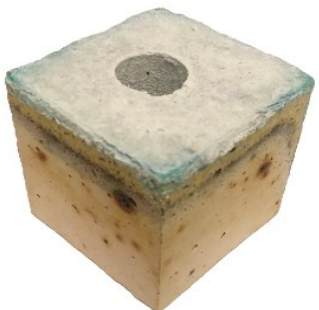

b)

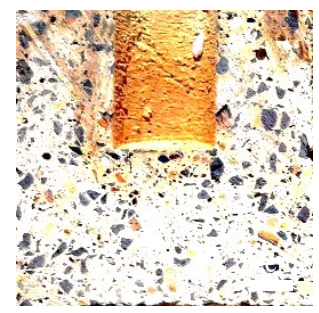

e)

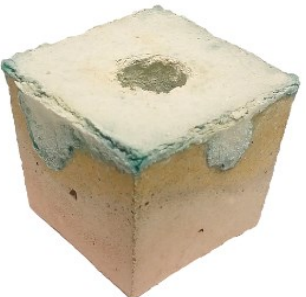

c)

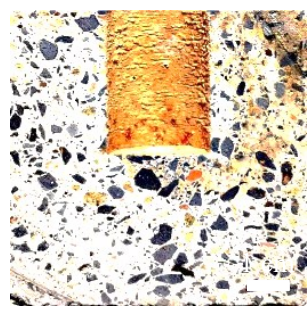

f)

3.21 pav. VCB serijos betono bandinių bendras $(a, b, c)$ ir skerspjūvio $(d, e, f)$ vaizdas po 3 šarminio atsparumo bandymo ciklų $1100{ }^{\circ} \mathrm{C}$ temperatūroje:

a, d - betonas VCB2; b, e - VCB3; c, f - VCB4

Fig. 3.21. General view (a, b, c) and cross sections (d, e, f) of castable samples of the VCB series after 3 cycles of alkali resistance test at $1100{ }^{\circ} \mathrm{C}$ : a, d - castable VCB2; b, e - VCB3; c, f - VCB4 


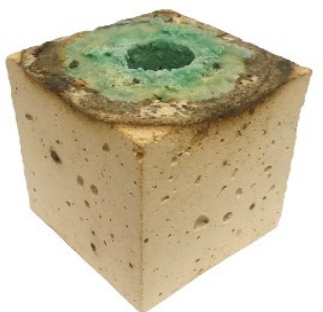

a)

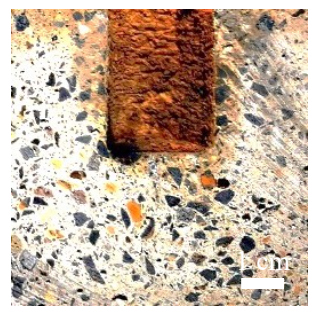

d)

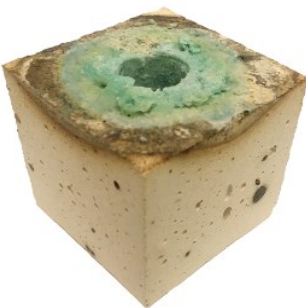

b)

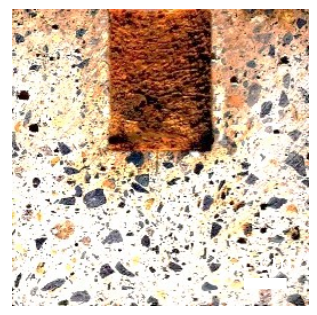

e)

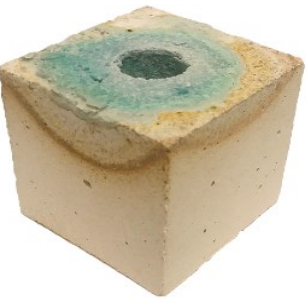

c)

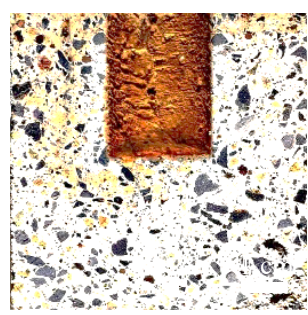

f)

3.22 pav. VCB serijos betono bandinių bendras (a, b, c) ir skerspjūvio (d, e, f) vaizdas po 6 ciklų šarminio atsparumo bandymo $1200{ }^{\circ} \mathrm{C}$ temperatūroje: $\mathrm{a}, \mathrm{d}$ - betonas VCB2; b, e - VCB3; c, f - VCB4

Fig. 3.22. General view (a, b, c) and surface sections $(d, e, f)$ of castable samples of VCB series after 6 cycles of alkali resistance test at $1200{ }^{\circ} \mathrm{C}$ :

a, d - castable VCB2; b, e - VCB3; c, f - VCB4

\subsection{Apsauginio barjero formavimosi ypatumai}

Šiame skyriuje tiriami BQ3, BQ4, VCB3, VCB4 betonai pasižymintys didžiausiu terminiu atsparumu. Tai netaikytina betonams su BOS 125 šamoto užpildu (BQ2 ir VCB2 markių betonams).

Nustatyta tiriamų betonų cheminè sudètis, kuri pateikta 3.4 lentelëje. Galima pastebėti, kad pateiktų betonų bandinių sekoje $\mathrm{Al}_{2} \mathrm{O}_{3}$ kiekis didejja nuo 34 iki $\sim 51 \%, \mathrm{o} \mathrm{Al}_{2} \mathrm{O}_{3} / \mathrm{SiO}_{2}$ santykis - nuo 0,77 iki 1,26.

3.4 lentelè taip pat rodo, kad pateiktų tiriamujų betonų pirmujų 6-ų oksidų $\left(\mathrm{Al}_{2} \mathrm{O}_{3}, \mathrm{SiO}_{2}, \mathrm{CaO}, \mathrm{Fe}_{2} \mathrm{O}_{3}, \mathrm{~K}_{2} \mathrm{O}\right.$ ir $\left.\mathrm{Na}_{2} \mathrm{O}\right)$ sudéčių suma atitinka masès \%: BQ3 - 97,07; BQ4 - 97,67; VCB3 - 97,77; VCB4 - 98,45. Tai būdinga ugniai atsparių betonų su šamoto užpildais cheminei sudéčiai, kuri iš esmès priskiriama aliumosilikatinèms medžiagoms. Reikia pastebėti, jog iš viso tiriamuose betonuose buvo identifikuoti 22 oksidai. 
3.4 lentelè. Tiriamų betonų cheminė sudètis, masės \%

Table 3.4. Chemical composition of castables, $\%$ by weight

\begin{tabular}{|c|c|c|c|c|c|}
\hline \multirow{2}{*}{ Eil. Nr. } & \multirow{2}{*}{$\begin{array}{c}\text { Cheminè sudètis, } \\
\text { masės } \%\end{array}$} & \multicolumn{4}{|c|}{ Betono sudèties žymuo } \\
\hline & & BQ3 & BQ4 & VCB3 & VCB4 \\
\hline 1 & $\mathrm{Al}_{2} \mathrm{O}_{3}$ & 34,4681 & 41,4933 & 44,0847 & 51,0958 \\
\hline 2 & $\mathrm{SiO}_{2}$ & 44,5473 & 38,5851 & 46,0522 & 40,5176 \\
\hline 3 & $\mathrm{CaO}$ & 11,2981 & 11,4190 & 4,6384 & 4,4641 \\
\hline 4 & $\mathrm{Fe}_{2} \mathrm{O}_{3}$ & 5,7114 & 5,4012 & 1,9715 & 1,5794 \\
\hline 5 & $\mathrm{~K}_{2} \mathrm{O}$ & 0,9162 & 0,6354 & 0,8052 & 0,5411 \\
\hline 6 & $\mathrm{Na}_{2} \mathrm{O}$ & 0,1261 & 0,1392 & 0,2140 & 0,2482 \\
\hline 7 & $\mathrm{MgO}$ & 0,5110 & 0,4045 & 0,4056 & 0,2962 \\
\hline 8 & $\mathrm{ZrO}_{2}$ & 0,0382 & 0,0372 & 0,0328 & 0,0221 \\
\hline 9 & $\mathrm{TiO}_{2} *$ & 1,3832 & 1,3820 & 0,9411 & 0,7690 \\
\hline 10 & $\mathrm{SO}_{3}$ & 0,2622 & 0,1520 & 0,1821 & 0,1192 \\
\hline 11 & $\mathrm{PbO}$ & 0,1536 & 0,0099 & 0,1524 & 0,0063 \\
\hline 12 & $\mathrm{WO}_{3}$ & 0,0990 & 0,0850 & 0,0890 & 0,1010 \\
\hline 13 & $\mathrm{CuO}$ & 0,0960 & 0,0071 & 0,1110 & 0,0055 \\
\hline 14 & $\mathrm{Cr}_{2} \mathrm{O}_{3}$ & 0,0921 & 0,0380 & 0,0922 & 0,0200 \\
\hline 15 & $\mathrm{P}_{2} \mathrm{O}_{5}$ & 0,0720 & 0,0660 & 0,1131 & 0,1120 \\
\hline 16 & $\mathrm{MnO}$ & 0,0292 & 0,0240 & 0,0160 & 0,0130 \\
\hline 17 & $\mathrm{SrO}$ & 0,0167 & 0,0174 & 0,0091 & 0,0091 \\
\hline 18 & $\mathrm{Co}_{2} \mathrm{O}_{3}$ & 0,0150 & 0,0101 & 0,0110 & 0,0130 \\
\hline 19 & $\mathrm{NiO}$ & 0,0144 & 0,0108 & 0,0048 & 0,0031 \\
\hline 20 & $\mathrm{Ga}_{2} \mathrm{O}_{3}$ & 0,0072 & 0,0093 & 0,0078 & 0,0078 \\
\hline 21 & $\mathrm{Rb}_{2} \mathrm{O}$ & 0,0071 & 0,0041 & 0,0070 & 0,0049 \\
\hline 22 & $\mathrm{Nb}_{2} \mathrm{O}_{5}$ & 0,0051 & 0,0050 & 0,0054 & 0,0042 \\
\hline \multicolumn{2}{|c|}{ 1-6 oksidų suma } & 97,0672 & 97,6732 & 97,7660 & 98,4462 \\
\hline \multicolumn{2}{|c|}{ Visų oksidų suma } & 99,8692 & 99,9356 & 99,9464 & 99,9526 \\
\hline \multicolumn{2}{|c|}{ Kiti } & 0,1308 & 0,0644 & 0,0536 & 0,0474 \\
\hline
\end{tabular}

Pastaba: *-mineraloginès sudèties tyrimams naudojama kaip etaloninė medžiaga.

Atliekant tolesnę korozijos tyrimų rezultatų analizę, apsiribota tik pirmujų 9-ų oksidų paieška, o elementinès analizès atveju - $\mathrm{Al}, \mathrm{Si}, \mathrm{Ca}, \mathrm{K}$ ir O. Tiriami paviršiuje susidariusio apsauginio barjero (paveikto ir nepaveikto kaliu) betono sluoksniai panaudojant tiglio metodu tirtus bandinius (2.3 pav.). 


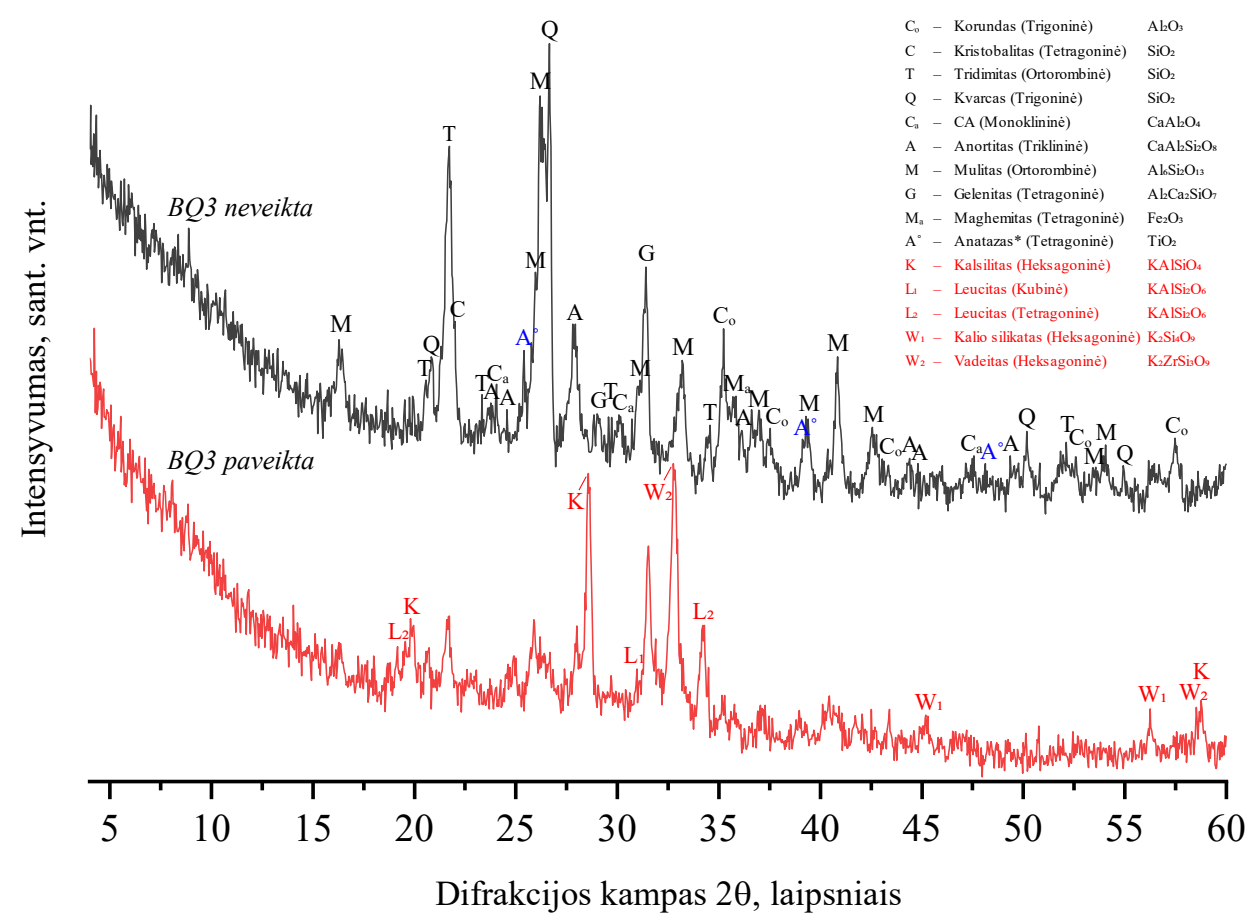

3.23 pav. Kontrolinio BQ3 betono po 3 terminių ciklų $1100^{\circ} \mathrm{C}$ temperatūroje ir analogiško betono po 3 šarminio atsparumo ciklų, veikiant $\mathrm{K}_{2} \mathrm{CO}_{3}$, rentgenogramos su charakteringų mineralų atžymomis

Fig. 3.23. X-ray diffraction patterns with characteristic mineral marks of control BQ3 castable after 3 thermal cycles at $1100{ }^{\circ} \mathrm{C}$ and analogous castable after 3 cycles of alkali resistance under $\mathrm{K}_{2} \mathrm{CO}_{3}$

Kaip matyti iš XRD tyrimų rezultatų, pateiktų 3.23 paveiksle, kontrolinis (nepaveiktas) BQ3 betonas, kaip ir BQ4 (A priedas), yra sudarytas iš 10 mineralų, o analogiškai paveiktas betonas, susidaręs apsauginio barjero zonoje, savo sudetyje turi papildomus 5 mineralus (korozijos produktus), kurie fiksuoti bandinio paviršiaus $\sim 1 \mathrm{~mm}$ storio sluoksnyje (2.3 pav. b) po 3-jų šarminio atsparumo ciklų $1100{ }^{\circ} \mathrm{C}$ temperatūroje. Pavyzdžiui, mineralas korundas susideda iš $\mathrm{Al}$ ir $\mathrm{O}$ atomų, mineralai kvarcas, kristobalitas ir tridimitas - iš $\mathrm{Si}$ ir $\mathrm{O}$ atomų, $\mathrm{CA}$ - iš $\mathrm{Ca}, \mathrm{Al}$ ir $\mathrm{O}$ atomų, anortitas ir gelenitas - iš $\mathrm{Ca}, \mathrm{Al}, \mathrm{Si}$ ir $\mathrm{O}$ atomų, mulitas - iš $\mathrm{Al}, \mathrm{Si}$ ir $\mathrm{O}$ atomų, maghemitas - iš $\mathrm{Fe}$ ir $\mathrm{O}$ atomų ir anatazas - iš $\mathrm{Ti}$ ir $\mathrm{O}$ atomų.

Anortitas yra naujadaras, susidarantis $\mathrm{SiO}_{2}-\mathrm{Al}_{2} \mathrm{O}_{3}-\mathrm{CaO}$ sistemos aukštoje temperatūroje (Traore et al. 2003). Jo susidarymą ugniai atspariuose betonuose su 
kalcio aliuminatiniu cementu skatina amorfiniu $\mathrm{SiO}_{2}$ mikrodulkiu priedas (Goberis et al. 2001, Firoozjaei et al. 2010). Pastarasis buvo panaudotas BQ ir VCB serijos betonuose.

Koroziniai mineralai, susidarę apsauginiame berjere, savo sudètyje turi kali (3.23 pav. BQ3 paveikta). Kalsilitas, kubinis leucitas ir tetragoninis leucitas turi savo sudètyje K, Al, Si ir O atomų. Kalio silikatas yra sudarytas iš K, Si ir O atomų, o vadeitas sudarytas iš $\mathrm{K}, \mathrm{Zr}, \mathrm{Si}$ ir $\mathrm{O}$ atomų. Kalsilito ir leucito formavimasis, veikiant šarminiam reagentui, yra būdingas aliumosilikatinėms medžiagoms, ir tai iliustruoja pirmajame skyriuje pateikta literatūros analizè bei 3.1 poskyrio tyrimo rezultatai.

Žinoma (Корнеев et al. 1991, Sodium and potassium silicates 2004), kad kalio silikato stiklas (luitas) susidaro $>1000{ }^{\circ} \mathrm{C}$ temperatūroje, reaguojant kalio karbonatui ir kvarciniam smèliui. Priklausomai nuo ịvairių faktorių (stiklo aušinimo sąlygų ir kitų) stikle gali kristalizuotis ir kalio silikatai (Lu et al. 1983). Paveiktos medžiagos rentgenogramoje ( 3.23 pav.) palyginus su nepaveikto betono rentgenograma, stebimas šiek tiek didesnis amorfinès fazès ,kalnas“ difrakcijos kampo intervale tarp 18 ir 38 laipsnių. Matyt, aliumosilikatiniame betone reaguojant kvarcui (kvarcinio smèlio priedas) ir kalio karbonatui, susidaro tam tikras kalio silikato stiklo fazès kiekis ir dalis kalio silikato kristalizuojasi.

Vidutinio cemento kiekio betone (3.24 pav.), pastebèta, jog kontrolinio VCB4 (kaip ir VCB3, A priedas) betono po degimo $1100{ }^{\circ} \mathrm{C}$ temperatūroje sudètyje yra 10 mineralų. Šiame betone, palyginus su BQ serijos betonais, gelenita pakeičia grositas. Tai mineralai, esantys A40 (gelenitas) ir A70 (grositas) markès cementuose, atitinkamai panaudotuose BQ ir VCB seriju betonu bandiniuose. Grositas susideda iš Al, Ca ir O atomų. Paveikto VCB4 betono paviršiaus sluoksnyje (kaip ir VCB3) po 3-ju šarminio atsparumo ciklų susidaro tie patys, kaip ir paminèta anksčiau (3.23 pav.), mineralai (korozijos produktai) kalsilitas, skirtingos kristalinès formos leucitas, kalio silikatas ir vadeitas.

Atlikti tyrimai rodo, kad $1100{ }^{\circ} \mathrm{C}$ temperatūroje nepriklausomai nuo $\mathrm{Al}_{2} \mathrm{O}_{3} / \mathrm{SiO}_{2}$ santykio šamoto užpilde, ịprastiniame ir vidutinio cemento kiekio betone su malto kvarcinio smèliu priedu dèl kalio ir betono komponentų reakcijos bandiniu paviršiuje susidaro korozijos produktai. Kalio silikatas ir papildomas stiklo fazès kiekis susidaro dèl kalio ir kvarco (kvarcinio smèlio) reakcijos.

Ugniai atsparius betonus, o ypač su aliumosilikatiniais užpildais, $\mathrm{SiO}_{2}$ mikrodulkėmis, kvarciniu smèliu, aliuminio oksido ir kitais modifikuojančiais priedais bei dviejų rūšių cementinèmis rišamosiomis medžiagomis, galima nagrinèti kaip porų ir kapiliarų sistemas. Tokiu požiūriu ugniai atsparūs betonai tampa panašūs ị šamoto arba keramikines plytas. Šios poringos sistemos, pasižymi porų ir kapiliarų atitinkamu pasiskirstymu pagal diametrą, tekstūriniais defektais, struktūros anizotropija, jos netolygumu ir kitais ypatumais, (Mačiulaitis 1996; 
Мачюлайтис 1997; Mačiulaitis et al. 2012). Šie aspektai yra svarbūs vertinant šarminio reagento prasiskverbimą ị skirtingos rūšies betono struktūrą.

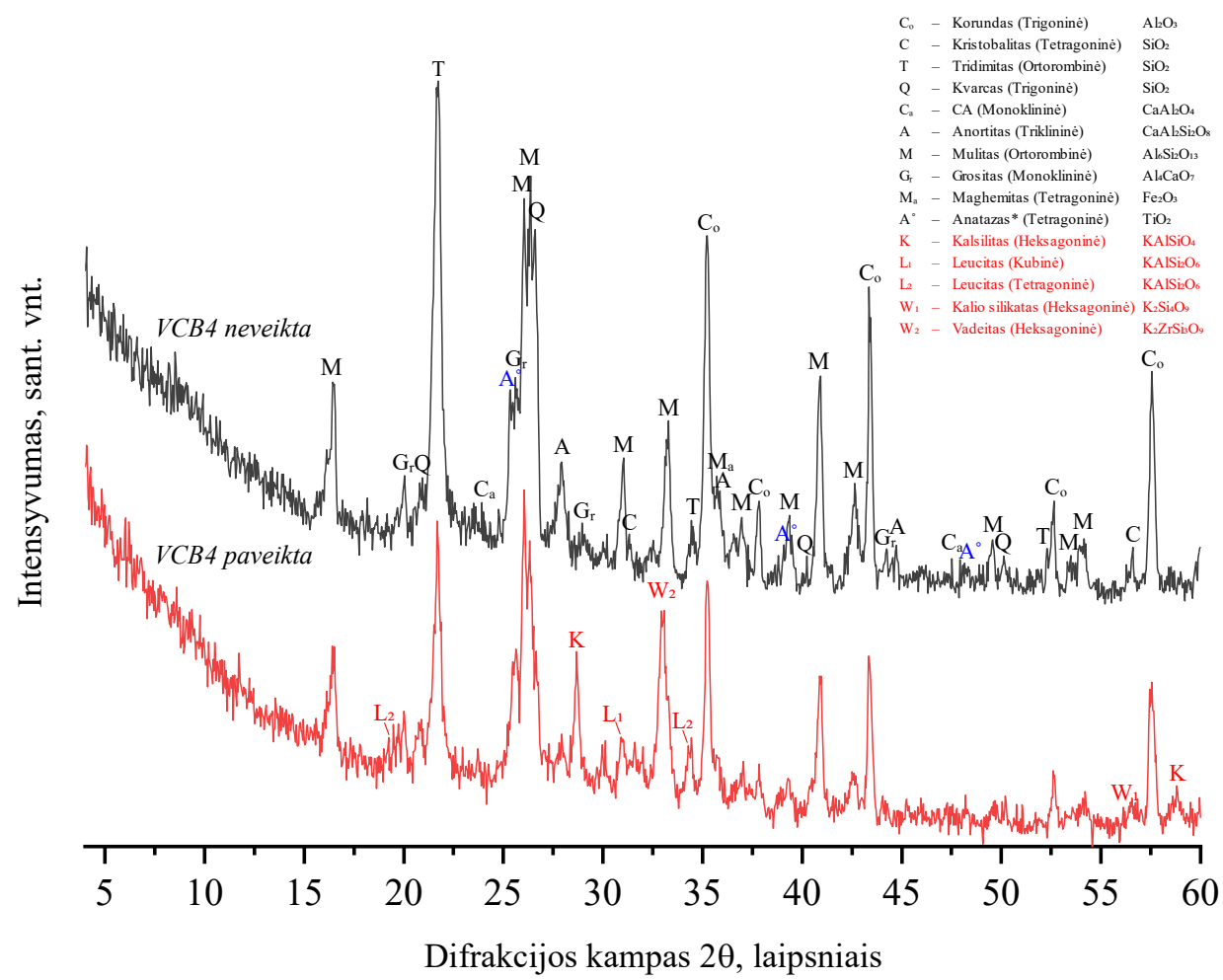

3.24 pav. Kontrolinio VCB4 betono po 3 terminių ciklu $1100^{\circ} \mathrm{C}$ temperatūroje ir analogiško betono po 3 šarminio atsparumo ciklų, veikiant $\mathrm{K}_{2} \mathrm{CO}_{3}$, rentgenogramos su charakteringų mineralų atžymomis

Fig. 3.24. X-ray diffraction patterns with characteristic mineral marks of control VCB4 castable after 3 thermal cycles at $1100{ }^{\circ} \mathrm{C}$ and analogous castable after 3 cycles of alkali resistance under $\mathrm{K}_{2} \mathrm{CO}_{3}$

3.25 paveiksle pateiktas visų tirtų betonų, po 3 šarminio atsparumo ciklų $1100{ }^{\circ} \mathrm{C}$ temperatūroje, vizualus kalio pasiskirstymas, gautas EDS tyrimų pagalba (analizuojamas $\sim 1500 \mu \mathrm{m}$ storis medžiagos sluoksnis). Kaip matome, kalio koncentracija paviršiaus bandinio sluoksnyje, kuriame susiformavo apsauginis barjeras, yra pakankamai didelè. Zonoje žemiau barjero (toliau minima kaip likusi zona) kalio koncentracija yra akivaizdžiai sumažejusi. 


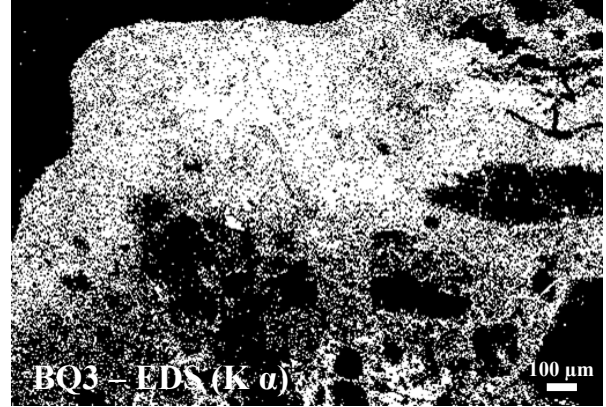

a)

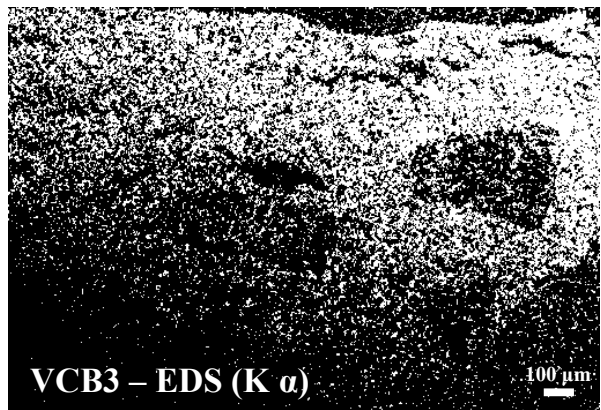

c)

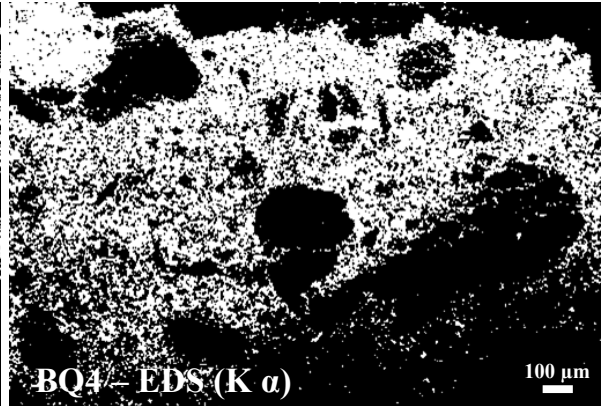

b)

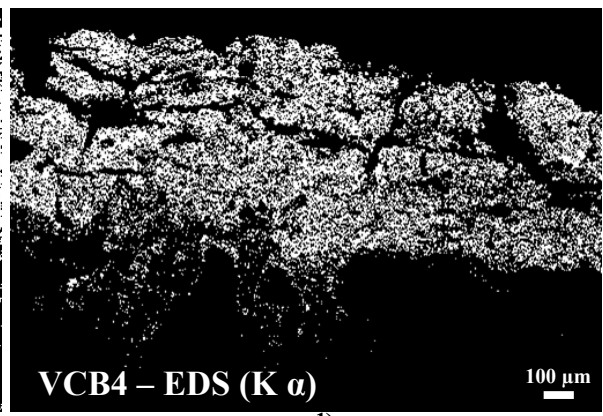

d)

3.25 pav. İvairių betonų kalio pasiskirstymas EDS žemėlapiuose po 3 šarminio atsparumo ciklų veikiant $\mathrm{K}_{2} \mathrm{CO}_{3} 1100{ }^{\circ} \mathrm{C}$ temperatūroje: a) BQ3 betono paviršius; b) BQ4 betono paviršius; c) VCB3 betono paviršius; d) VCB4 betono paviršius

Fig. 3.25. Potassium distribution of various castables in EDS maps after 3 cycles of alkali resistance with $\mathrm{K}_{2} \mathrm{CO}_{3}$ at $1100{ }^{\circ} \mathrm{C}$ : a) BQ3 castable surface;

b) BQ4 castable surface; c) VCB3 castable surface; d) VCB4 castable surface

3.26-3.29 paveiksluose pateiktos tiriamų betonų po 3-jų šarmino atsparumo ciklų šlifų SEM paviršiaus nuotraukos (jose analizuojamas $\sim 2500 \mu \mathrm{m}$ storio medžiagos sluoksnis). Numeriais pažymètos lokalios vietos, kuriose buvo tirta elementinè $(\mathrm{K}, \mathrm{Al}, \mathrm{Si}, \mathrm{Ca} \mathrm{O})$ visų aliumosilikatinių betonų, turinčių minètų atomų, koncentracija. Kaip matyti iš 3.26-3.29 paveikslų pateiktų duomenų, visuose pažymètuose plotuose matomi tik lokalių $\mathrm{K}, \mathrm{Al}$ ir Si koncentracijų rezultatai masès procentais. Šie duomenys, kaip matyti iš žemiau pateiktos 3.5 lentelès, iš viso sudaro $100 \%$ kartu su nustatytais $\mathrm{Ca}$ ir O kiekiais. 


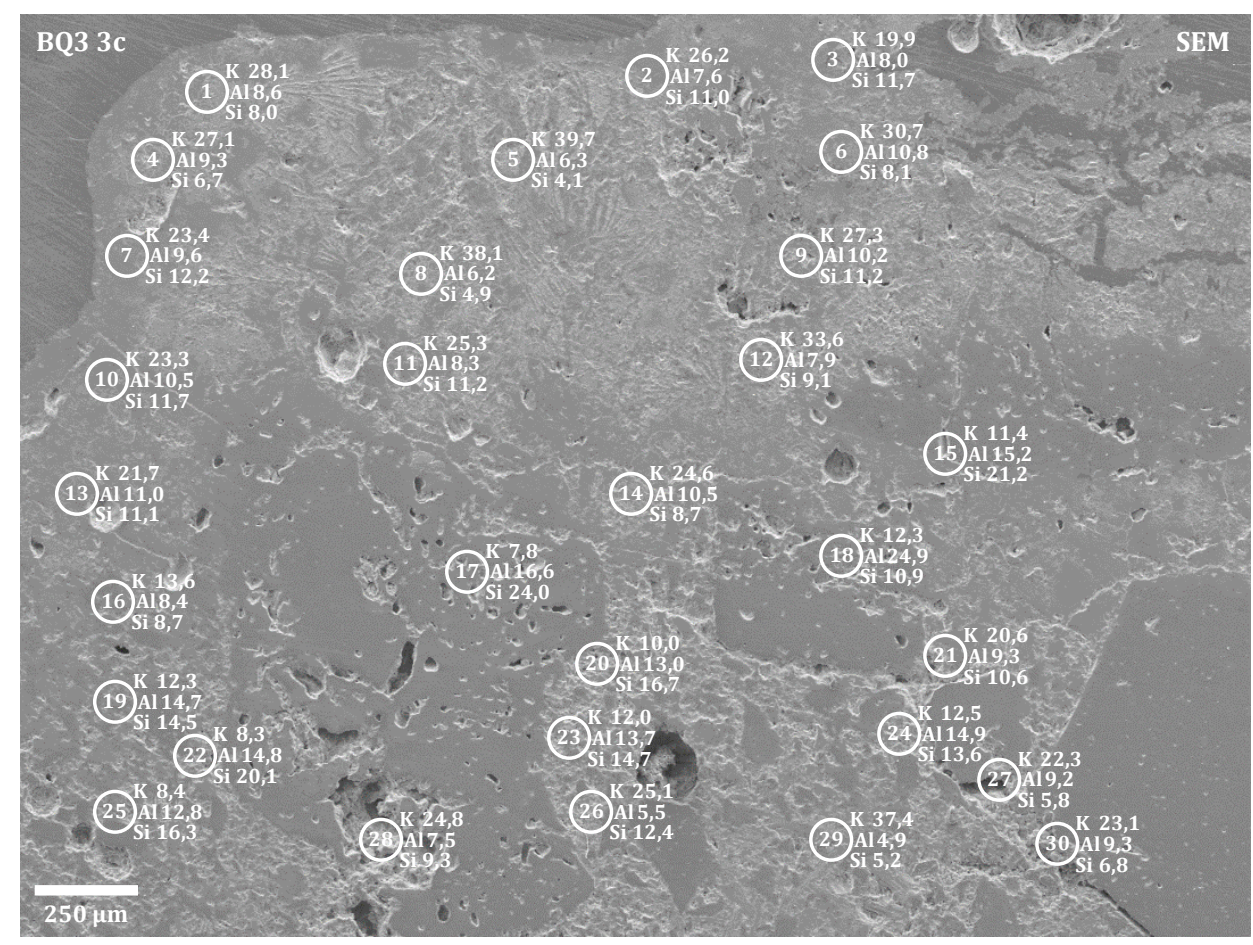

3.26 pav. BQ3 bandinio skerspjūvio SEM vaizdas po 3 šarminio atsparumo ciklų, veikiant $\mathrm{K}_{2} \mathrm{CO}_{3}$ ir $1100{ }^{\circ} \mathrm{C}$ temperatūrai, cheminių $\mathrm{K}$, $\mathrm{Al}$ ir Si elementų (\%) lokalus pasiskirstymas ugniai atspariame betone

Fig. 3.26. $\mathrm{SEM}$ image of $\mathrm{BQ} 3$ sample cross section after 3 alkali resistance cycles at $\mathrm{K}_{2} \mathrm{CO}_{3}$ and $1100{ }^{\circ} \mathrm{C}$, local distribution of chemical elements $\mathrm{K}$, $\mathrm{Al}$ and $\mathrm{Si}(\%)$ in refractory castable

Analizuojant paminètų paveikslų SEM nuotraukas, matoma, kad visi trys elementai $(\mathrm{K}, \mathrm{Al}, \mathrm{Si})$ yra pasiskirstę netolygiai bandinio $\sim 2500 \mu \mathrm{m}$ storio betono paviršiaus sluoksnyje. Tuo galima paaiškinti ne tik barjero susidarymą, bet ir ugniai atsparaus betono mikrostruktūros ypatumus. Bendru atveju mikrostruktūros ypatumus apsprendžia panaudotų komponentų granuliometrija ir cheminè sandara, naudojama cemento rūšis, modifikuojančių priedų savybès ir kt.

BQ3 betone po 3 šarminio atsparumo ciklų, veikiant $\mathrm{K}_{2} \mathrm{CO}_{3}$ ir $1100^{\circ} \mathrm{C}$ temperatūrai, apsauginis barjeras susiformavo $\sim 1300 \mu \mathrm{m}$ storio betono paviršiaus sluoksnyje, kuriame K koncentracija yra didžiausia ir svyruoja 19,9 \% - 39,7 \% intervale (3.26 pav.). Likusioje zonoje žemiau barjero, $\mathrm{K}$ koncentracija yra gerokai mažesnè $(7,8-13,6 \%$, taškai $15,16,17,18)$. 


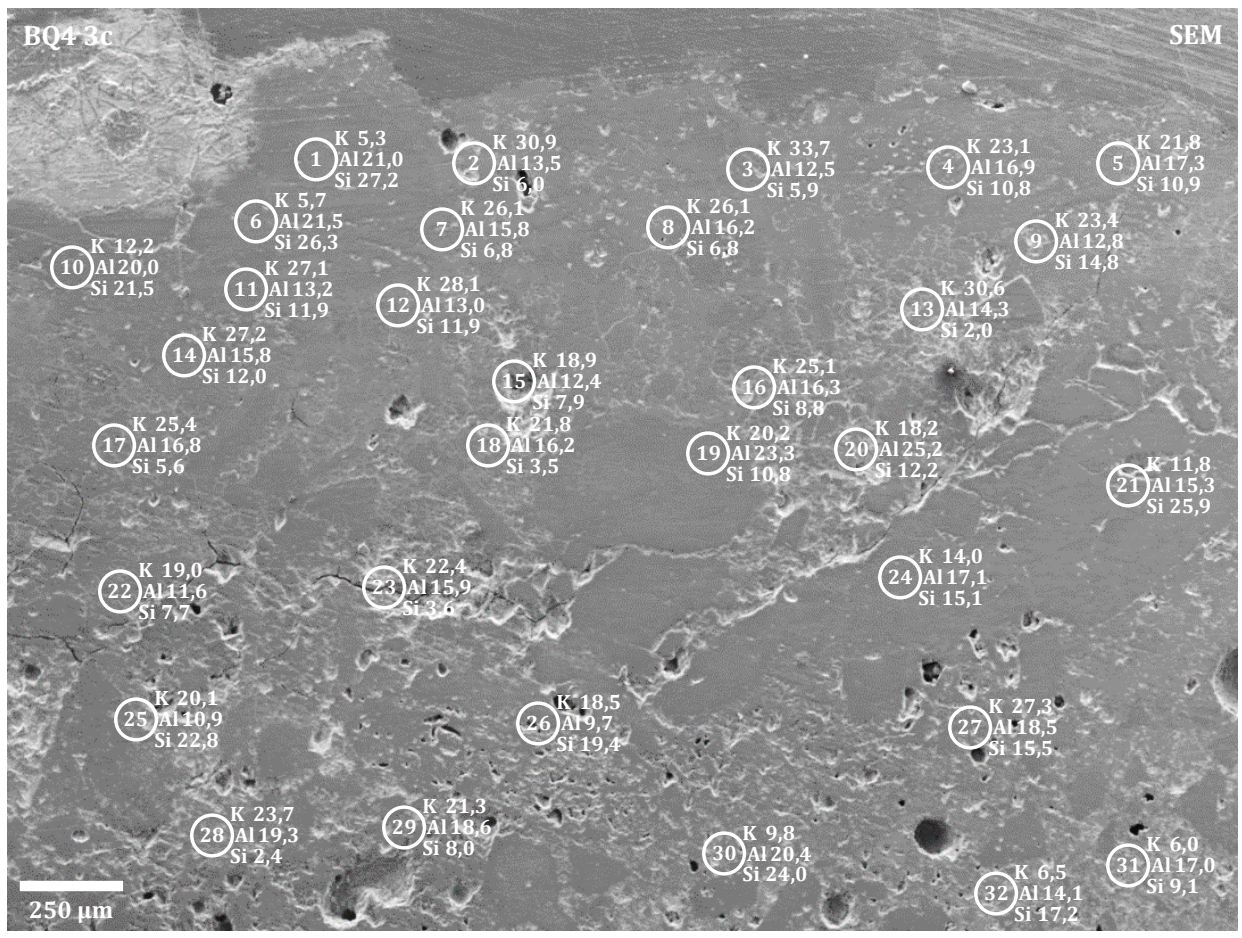

3.27 pav. $B Q 4$ bandinio skerspjūvio SEM vaizdas po 3 šarminio atsparumo ciklų, veikiant $\mathrm{K}_{2} \mathrm{CO}_{3}$ ir $1100{ }^{\circ} \mathrm{C}$ temperatūrai, cheminių $\mathrm{K}, \mathrm{Al}$ ir Si elementų (\%) lokalus pasiskirstymas ugniai atspariame betone

Fig. 3.27. SEM image of $B Q 4$ sample cross section after 3 alkali resistance cycles at $\mathrm{K}_{2} \mathrm{CO}_{3}$ and $1100{ }^{\circ} \mathrm{C}$, local distribution of chemical elements $\mathrm{K}, \mathrm{Al}$ and $\mathrm{Si}(\%)$ in refractory castable

Tai charakterizuoja apsauginio barjero netolygumą ir $\mathrm{K}$ jonų prasiskverbimo per susidariusi apsauginị barjerą potencialą. Reikia pažymèti, kad K jonai gali lengvai skverbtis per susisiekiančias betono struktūroje stambias poras, mikroitrūkius ir kitus defektus ( $\mathrm{Li}$ et al. 2017). BQ3 betono atveju, tai rodo nustatytos $\sim 2000 \mu \mathrm{m}$ gylio sluoksnyje didelès $\mathrm{K}$ koncentracijos porų zonose $(>15 \%$, taškai $26,27,28)$. Tokie plotai stebimi ir BQ4 bei VCB3 betono struktūroje (3.27 ir 3.28 pav.). VCB4 betone apsauginis barjero storis yra mažiausias $(\sim 700 \mu \mathrm{m})$, didelių K koncentracijų (>10\%) likusioje zonoje šalia porų nepastebèta (3.29 pav.).

Tiriamų ugniai atsparių betonų poringą struktūrą, ịskaitant jos diskretiškumą, objektyviai charakterizuoja ne tik K, bet ir elementų $\mathrm{Al}, \mathrm{Si}, \mathrm{Ca}$ ir O koncentracijų pasiskirstymas 100 procentų intervale. 


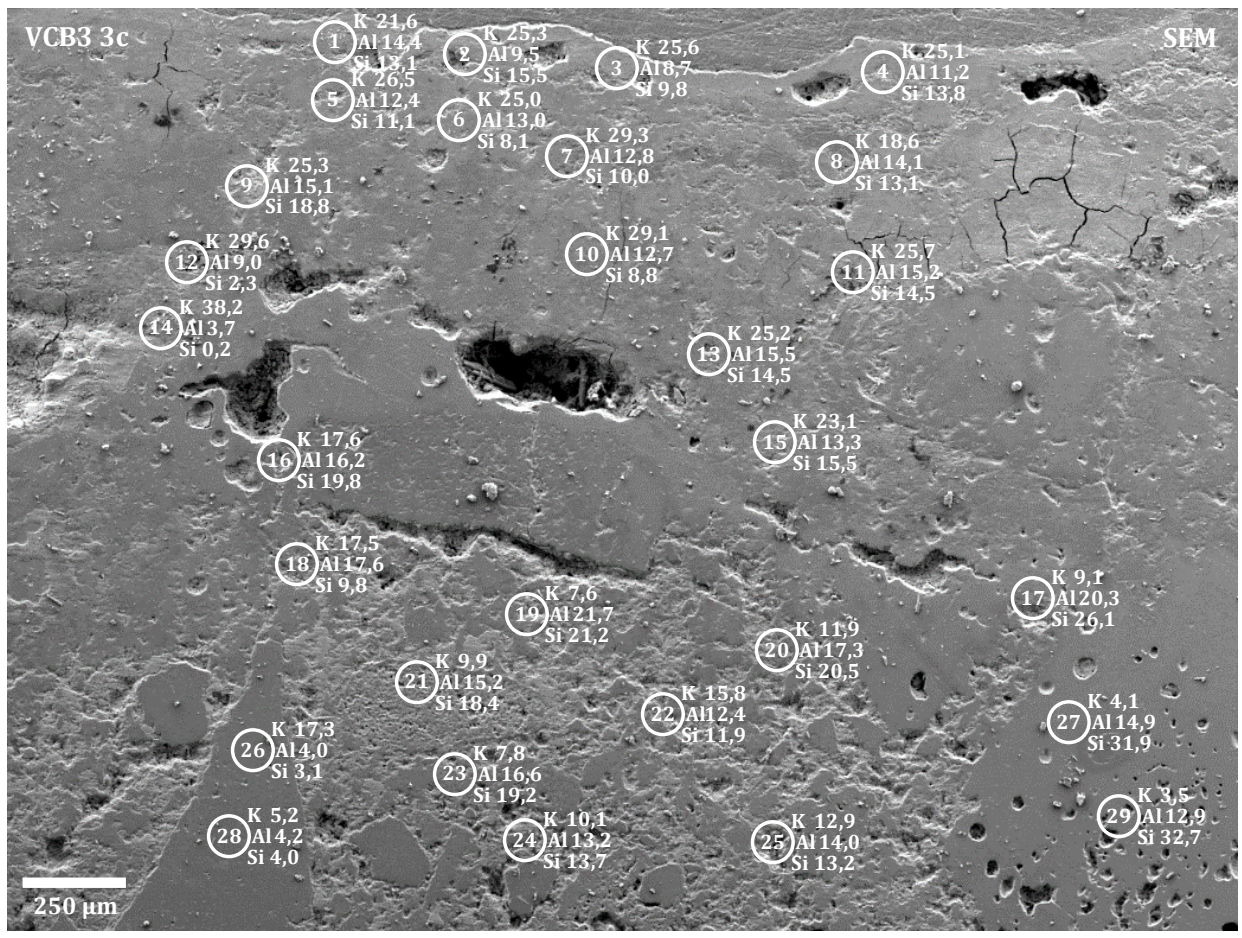

3.28 pav. VCB3 bandinio skerspjūvio SEM vaizdas po 3 šarminio atsparumo ciklų, veikiant $\mathrm{K}_{2} \mathrm{CO}_{3}$ ir $1100{ }^{\circ} \mathrm{C}$ temperatūrai, cheminių $\mathrm{K}$, $\mathrm{Al}$ ir Si elementų (\%) lokalus pasiskirstymas ugniai atspariame betone

Fig. 3.28. SEM image of VCB3 sample cross section after 3 alkali resistance cycles at $\mathrm{K}_{2} \mathrm{CO}_{3}$ and $1100{ }^{\circ} \mathrm{C}$, local distribution of chemical elements $\mathrm{K}, \mathrm{Al}$ and $\mathrm{Si}(\%)$ in refractory castable

Svarbi informacija pateikta 3.5 lenteleje apie apsauginio barjero ir likusios zonos įvardintas $(\mathrm{K}, \mathrm{Al}, \mathrm{Si}, \mathrm{Ca}, \mathrm{O})$ cheminių elementų vidutines vertes, prilygintas $100 \%$ po 3 ir 6 šarminio atsparumo ciklų BQ3, BQ4, VCB3 ir VCB4 betonams.

Kaip matyti iš minètų rezultatų, elementinè $\mathrm{K}$ koncentracija $\mathrm{BQ} 3$ betono barjero zonoje po 3-jų šarminio atsparumo ciklų yra $\sim 26 \%$, likusioje zonoje $\sim 17 \%$, o po 6-ių šarminio atsparumo ciklų barjero zonoje koncentracija išauga iki $\sim 39 \%$ ir likusioje zonoje iki $29 \%$. 


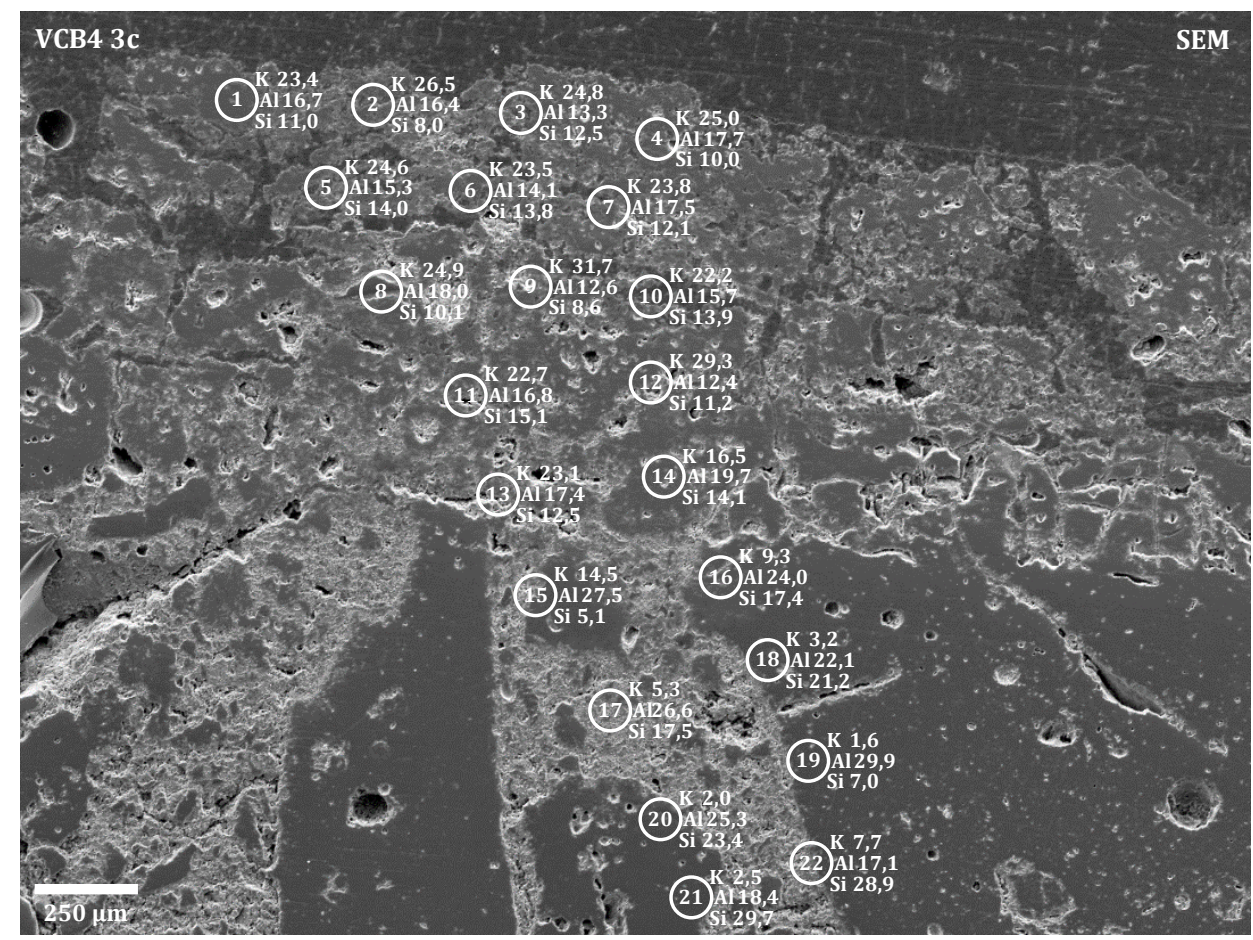

3.29 pav. VCB4 bandinio skerspjūvio SEM vaizdas po 3 šarminio atsparumo ciklų, veikiant $\mathrm{K}_{2} \mathrm{CO}_{3}$ ir $1100{ }^{\circ} \mathrm{C}$ temperatūrai, cheminių $\mathrm{K}$, $\mathrm{Al}$ ir Si elementų (\%) lokalus pasiskirstymas ugniai atspariame betone

Fig. 3.29. SEM image of VCB4 sample cross section after 3 alkali resistance cycles at $\mathrm{K}_{2} \mathrm{CO}_{3}$ and $1100{ }^{\circ} \mathrm{C}$, local distribution of chemical elements $\mathrm{K}, \mathrm{Al}$ and $\mathrm{Si}(\%)$ in refractory castable

Toks kitimas aiškiai rodo ne tik K koncentracijos augimą didejjant ciklų skaičiui, bet ir barjero storio padidejjimą (minimaliai nuo $\sim 1300 \mu \mathrm{m}$ iki $\sim 2400 \mu \mathrm{m}$ ). Veikiant šarminiams ciklams, galima prognozuoti ir tolimesnị K jonų prasiskverbimą i gilesnius medžiagos sluoksnius bei barjero storio didejjimą.

Betonuose BQ4, VCB3 ir VCB4 apsauginio barjero storis po 6-ių šarminio atsparumo ciklų tai pat padidejo, tačiau išliko zona, kurioje $\mathrm{K}$ koncentracija vis dar akivaizdžiai mažesnè negu apsauginiame barjere.

BQ4 betone barjero zonoje po 3-jų šarminio atsparumo ciklų K koncentracija $\sim 23 \%$, o likusioje zonoje $\sim 17 \%$, po 6-ių šarminio atsparumo ciklų barjero zonoje - $\sim 37 \%$, o likusioje zonoje - $\sim 20 \%$. Barjero storis padidejo nuo $\sim 1100 \mu \mathrm{m}$ iki $\sim 1250 \mu \mathrm{m}$. 
3.5 lentelè. Pagrindinių cheminių elementų procentiniai vidurkiai skirtingose betono zonose po 3 ir 6 šarminio atsparumo ciklų veikiant $\mathrm{K}_{2} \mathrm{CO}_{3} 1100{ }^{\circ} \mathrm{C}$ temperatūroje

Table 3.5. Percentage averages of the main chemical elements in different castable zones after 3 and 6 cycles of alkali resistance under $\mathrm{K}_{2} \mathrm{CO}_{3}$ at $1100{ }^{\circ} \mathrm{C}$

\begin{tabular}{|c|c|c|c|c|c|c|c|c|}
\hline \multirow{2}{*}{ Betonas } & \multirow{2}{*}{$\begin{array}{l}\text { Ciklų } \\
\text { skaičius }\end{array}$} & \multirow{2}{*}{$\begin{array}{c}\text { Zonos } \\
\text { charakteristika }\end{array}$} & \multicolumn{5}{|c|}{ Cheminių elementų vidurkiai, \% } & \multirow{2}{*}{ Suma, \% } \\
\hline & & & $\mathrm{K}$ & $\mathrm{Al}$ & $\mathrm{Si}$ & $\mathrm{Ca}$ & $\mathrm{O}$ & \\
\hline \multirow{4}{*}{ BQ3 } & \multirow{2}{*}{3} & $\begin{array}{c}\text { Barjero zona; } \\
\sim 1300 \mu \mathrm{m}\end{array}$ & 25,9 & 9,0 & 10,0 & 5,8 & 49,3 & 100,0 \\
\hline & & Likusi zona & 16,9 & 12,2 & 12,9 & 6,9 & 51,1 & 100,0 \\
\hline & \multirow[t]{2}{*}{6} & $\begin{array}{l}\text { Barjero zona; } \\
\sim 2400 \mu \mathrm{m}\end{array}$ & 39,2 & 8,0 & 3,1 & 1,3 & 48,4 & 100,0 \\
\hline & & Likusi zona & 28,9 & 9,9 & 9,5 & 4,6 & 47,1 & 100,0 \\
\hline \multirow{4}{*}{ BQ4 } & \multirow{2}{*}{3} & $\begin{array}{l}\text { Barjero zona; } \\
\sim 1100 \mu \mathrm{m}\end{array}$ & 22,6 & 16,7 & 11,2 & 1,8 & 47,7 & 100,0 \\
\hline & & Likusi zona & 16,7 & 15,7 & 14,2 & 5,2 & 48,2 & 100,0 \\
\hline & \multirow[t]{2}{*}{6} & $\begin{array}{l}\text { Barjero zona; } \\
\sim 1250 \mu \mathrm{m}\end{array}$ & 37,1 & 4,1 & 5,0 & 1,6 & 52,2 & 100,0 \\
\hline & & Likusi zona & 19,9 & 17,6 & 13,1 & 4,1 & 45,3 & 100,0 \\
\hline \multirow{4}{*}{ VCB3 } & \multirow[t]{2}{*}{3} & $\begin{array}{l}\text { Barjero zona; } \\
\sim 1200 \mu \mathrm{m}\end{array}$ & 25,7 & 12,3 & 11,8 & 1,5 & 48,7 & 100,0 \\
\hline & & Likusi zona & 10,2 & 14,2 & 17,4 & 2,0 & 56,2 & 100,0 \\
\hline & \multirow[t]{2}{*}{6} & $\begin{array}{c}\text { Barjero zona; } \\
\sim 1500 \mu \mathrm{m}\end{array}$ & 24,3 & 13,7 & 9,2 & 1,7 & 51,1 & 100,0 \\
\hline & & Likusi zona & 16,9 & 15,2 & 15,1 & 2,4 & 50,4 & 100,0 \\
\hline \multirow{4}{*}{ VCB4 } & \multirow[t]{2}{*}{3} & $\begin{array}{c}\text { Barjero zona; } \\
\quad 700 \mu \mathrm{m}\end{array}$ & 24,4 & 16,0 & 11,9 & 1,3 & 46,4 & 100,0 \\
\hline & & Likusi zona & 5,8 & 23,9 & 18,8 & 6,8 & 44,7 & 100,0 \\
\hline & \multirow[t]{2}{*}{6} & $\begin{array}{l}\text { Barjero zona; } \\
\sim 1500 \mu \mathrm{m}\end{array}$ & 23,4 & 13,1 & 11,4 & 2,8 & 49,3 & 100,0 \\
\hline & & Likusi zona & 13,2 & 19,3 & 14,1 & 5,0 & 48,4 & 100,0 \\
\hline
\end{tabular}

Tuo tarpu VCB3 betono atveju po 3 šarminio atsparumo ciklų $K$ koncentracija barjero zonoje siekè $\sim 26 \%$, o likusioje zonoje sumažejo iki $\sim 10 \%$. Po 6-ių šarminio atsparumo ciklų vidutinè K koncentracija barjero zonoje siekè $\sim 24 \%$ ir likusioje zonoje $-\sim 17 \%$. Tai rodo mažesnị K koncentracijos gradientą ir tuo pačiu didesni tokio betono prognozuojamą korozijos atsparumą palyginus su BQ serijos betonų atsparumu. Šiam betonui barjero storis padidejo nuo $\sim 1200 \mu \mathrm{m}$ iki $\sim 1500 \mu \mathrm{m}$.

Aptariant VCB4 betoną, po 3 šarminio atsparumo ciklų K koncentracija barjero zonoje siekė $\sim 24 \%$, o likusioje zonoje $-\sim 6 \%$. Po 6 šarminio atsparumo ciklų vidutinè K koncentracija barjero zonoje sudarè $\sim 23 \%$ ir likusioje zonoje - 
$\sim 13 \%$. Mažiausias K jonų skverbimasis per apsauginị barjerą leidžia tvirtinti, jog minèto VCB4 betono korozijos atsparumas yra maksimalus.

3.6 lentelè. Paveiktos betono zonos po 3 šarminio atsparumo ciklu $1100{ }^{\circ} \mathrm{C}$ temperatūroje, rentgenografinių tyrimų rezultatų suvestiné, atliekant analizę „Match!“ programa pagal Rietveld metodą

Table 3.6. Summary of X-ray examination results of the affected castable after 3 cycles of alkali resistance at $1100{ }^{\circ} \mathrm{C}$ by "Match!" program according to the Rietveld method

\begin{tabular}{|c|c|c|c|c|c|c|}
\hline \multirow{2}{*}{ Tipas } & \multirow{2}{*}{$\begin{array}{l}\text { Mineralas (kristalu } \\
\text { singonijos) }\end{array}$} & \multirow{2}{*}{ Formulè } & \multicolumn{4}{|c|}{ Betonai } \\
\hline & & & BQ3 & BQ4 & VCB3 & VCB4 \\
\hline \multirow{10}{*}{ 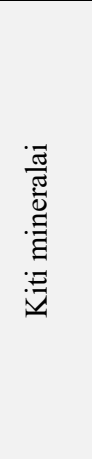 } & Korundas (Trigoninè) & $\mathrm{Al}_{2} \mathrm{O}_{3}$ & 4,0 & 6,4 & 9,7 & 13,9 \\
\hline & Kristobalitas (Tetragoninè) & $\mathrm{SiO}_{2}$ & 1,9 & 1,8 & 2,5 & 3,1 \\
\hline & Tridimitas (Ortorombinè) & $\mathrm{SiO}_{2}$ & 3,7 & 3,1 & 4,2 & 3,0 \\
\hline & Kvarcas (Trigoninė) & $\mathrm{SiO}_{2}$ & 2,2 & 1,3 & 4,3 & 3,6 \\
\hline & CA (Monoklininè) & $\mathrm{CaAl}_{2} \mathrm{O}_{4}$ & 4,9 & 4,9 & 4,8 & 4,7 \\
\hline & Anortitas (Triklininė) & $\mathrm{CaAl}_{2} \mathrm{Si}_{2} \mathrm{O}_{8}$ & 17,4 & 10,6 & 10,1 & 7,5 \\
\hline & Mulitas (Ortorombinè) & $\mathrm{Al}_{6} \mathrm{Si}_{2} \mathrm{O}_{13}$ & 14,2 & 19,6 & 17,8 & 33,0 \\
\hline & Gelenitas (Tetragoninè) & $\mathrm{Al}_{2} \mathrm{Ca}_{2} \mathrm{SiO}_{7}$ & 8,0 & 7,6 & - & - \\
\hline & Grositas (Monoklininè) & $\mathrm{Al}_{4} \mathrm{CaO}_{7}$ & - & - & 10,3 & 9,1 \\
\hline & Maghemitas (Tetragoninė) & $\mathrm{Fe}_{2} \mathrm{O}_{3}$ & 0,9 & 1,0 & 2,5 & 2,4 \\
\hline \multirow{5}{*}{ 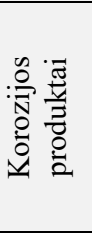 } & Kalsilitas (Heksagoninè) & $\mathrm{KAlSiO}_{4}$ & 10,6 & 7,3 & 7,7 & 4,3 \\
\hline & Leucitas (Kubinè) & $\mathrm{KAlSi}_{2} \mathrm{O}_{6}$ & 1,0 & 1,0 & 1,5 & 2,2 \\
\hline & Leucitas (Tetragoninè) & $\mathrm{KAlSi}_{2} \mathrm{O}_{6}$ & 7,7 & 7,4 & 5,7 & 5,6 \\
\hline & Kalio silikatas (Heksagoninè) & $\mathrm{K}_{2} \mathrm{Si}_{4} \mathrm{O}_{9}$ & 19,8 & 24,6 & 17,2 & 5,7 \\
\hline & Vadeitas (Heksagoninė) & $\mathrm{K}_{2} \mathrm{ZrSi}_{3} \mathrm{O}_{9}$ & 3,7 & 3,4 & 1,7 & 1,9 \\
\hline \multicolumn{3}{|c|}{ Betonų korozijos produktų suma, $\%$} & 42,8 & 43,7 & 33,8 & 19,7 \\
\hline \multicolumn{3}{|c|}{ Visų mineralų suma, $\%$} & 100,0 & 100,0 & 100,0 & 100,0 \\
\hline \multicolumn{3}{|c|}{ KRISTALINE் FAZE், \% } & 63,5 & 64,2 & 64,6 & 65,4 \\
\hline \multicolumn{3}{|c|}{ AMORFINE் FAZE் (stiklo), \% } & 36,5 & 35,8 & 35,4 & 34,6 \\
\hline \multicolumn{3}{|c|}{ Abiejų fazių suma, $\%$} & 100,0 & 100,0 & 100,0 & 100,0 \\
\hline
\end{tabular}

Apibendrinant galima teigti, kad faktinès cheminių elementų koncentracijos lokaliose vietose neleidžia numatyti konkrečių susidarančių junginių, iš paminètų elementų, ir tokių junginių fazių sudèties. Dèl šios priežasties buvo atlikta XRD duomenų po 3 šarminio atsparumo ciklų $1100^{\circ} \mathrm{C}$ temperatūroje $(3.23,3.24$ pav. ir 1, 2 pav., A priedas) analizè su „Match!“ programa, o skaičiavimai - pagal Rietveldo metodą.

Iš pateiktų 3.6 lentelèje duomenų matyti, kad visi paveikti betonai yra kristalinès ir amorfinès fazès. Pateikti rezultatai rodo, kad kristalinė fazè dominuoja prieš amorfinę. Taip kristalinė fazė BQ3 apsauginio barjero sluoksnyje sudaro $63,5 \%$ prieš amorfinę fazę lygią $36,5 \%$, BQ4 betone kristalinès fazès yra 
$64,2 \%$ - amorfinès fazès - 35,8 \%, VCB3 betone kristalinès fazès yra $64,6 \%$ amorfinès fazès - 35,4 \%, o VCB4 apsauginio barjero sluoksnyje kristalinè fazè sudaro $65,4 \%$ prieš amorfinę fazę lygią $34,6 \%$. Rezultatai rodo, kad visuose tirtuose betonuose kristalinès ir amorfinès fazès kiekis, nustatytas apsauginio barjero sluoksnyje, skiriasi mažai $( \pm 2 \%)$.Tuo tarpu iš 3.6 lentelèje pateiktų duomenų identifikuota betonų korozijos produktų suma, kuri susidaro kristalinèje fazejje: tai mineralai kalsilitas, kubinis ir tetragoninis leucitas, kalio silikatas ir vadeitas. Nustatyta, kad betonų korozijos produktų suma po 3 šarminès korozijos ciklų BQ3 betone sudaro 42,8 \%, BQ4 betone $-43,7 \%$, VCB3 betone $-33,8 \%$ ir VCB4 betone - 19,7\%. Ir tai, nepriklausomai nuo apsauginio barjero susidarymo visuose betonuose, iš dalies leidžia prognozuoti tiriamujų betonų atsparumą korozijai. Pagal ši rodiklị BQ tipo betonai yra mažiausiai atsparūs korozijai, VCB3 betonai yra vidutinio korozijos atsparumo, VCB4 yra atspariausi korozijai.

Remiantis gautais tyrimo rezultatais, galima teigti, kad kvarcinio smèlio priedas turi itakos apsauginio barjero formavimuisi šamoto betonuose skatinant amorfinès fazès (stiklo) susidarymą. Galima manyti, kad aukštoje temperatūroje ne tik stiklo lydalas, bet ir augantys kristaliniai korozijos produktai uždaro betone dominuojančias poras ir kapiliarus. Galbūt taip yra formuojama apsauginio barjero zona. Barjero mineraloginè sudètis priklauso nuo betono rūšies ir nustatyta, kad korozijos produktų, kurie susidaro kristalinejje fazèje, kiekis yra didžiausias BQ serijos, mažiausias VCB serijos betonuose. Barjeras yra diskretus ir, didejjant šarminių ciklų skaičiui, didèja ne tik jo storis, bet vyksta ir K prasiskverbimas ị medžiagos struktūrą. Barjero storiui ir $\mathrm{K}$ prasiskverbimo potencialui ịtakos turi ugniai atsparūs betono mikrostruktūros ypatumai. Mažiausias K prasiskverbimas ị medžiagos struktūrą nustatytas VCB4 betone, kuris pasižymi tankiausia struktūra, mažiausiu poringumu ir didžiausiu terminiu atsparumu (mažiausia destrukcija veikiant terminiams smūgiams).

Atliekant 20 šarminio atsparumo ciklų, nepastebetas kalio prasiskverbimas per apsauginị barjerą. Taip pat nepastebètas ir kritinis poveikis visų betono bandinių būklei.

Nustatyti barjero formavimosi ypatumai leidžia prognozuoti, kad iš visų tirtų betonų atspariausias šarminei korozijai yra VCB4. Taip pat reikia pažymėti, kad kalio prasiskverbimas stebimas betono matricoje, jo difuzija ị užpildus po 6-ų šarminių ciklų yra minimali. Tai rodo, kad turètų būti numatyti tyrimai matricos atsparumo šarminio prasiskverbimo padidinimui.

Darbe nustatyti atsparesnio šarminei korozijai barjero formavimosi šamotiniuose betonuose, cikliškai veikiant $\mathrm{K}_{2} \mathrm{CO}_{3}$ ir aukštai temperatūrai, ypatumai: barjero zonoje kalis skverbiasi vis gilyn su kiekvienu ciklu; barjero zona sudaryta iš kristalinès ir amorfinès (stiklo) fazès; kalio naujadarų (korozijos produktų) kiekis vis didejja su kiekvienu ciklu. Tai yra pagrindiniai korozijos 
intensyvumo prognozavimo kriterijai (tiek absoliuti suma \%, tiek jos kiekio augimas su ciklais). Visa tai leidžia vertinti ir barjero stabilumą $1100{ }^{\circ} \mathrm{C}$ temperatūroje veikiant šarminiams korozijos ciklams.

\subsection{Trečiojo skyriaus išvados}

1. Rentgenografiniai šamoto užpildų tyrimai parodè, kad cikliškai veikiant $\mathrm{K}_{2} \mathrm{CO}_{3}$, jau po 5 val. degimo $1100{ }^{\circ} \mathrm{C}$ ir $1200{ }^{\circ} \mathrm{C}$ temperatūroje, bandiniuose susidaro šarminès korozijos produktai - leucitas ir kalsilitas. Korozijos produktų susidarymo reakcijose dalyvauja šamote esantys mineralai: mulitas, kvarcas, tridimitas ir korundas (jų smailių intensyvumai mažèja); prailginant temperatūrinio apdorojimo $1100{ }^{\circ} \mathrm{C}$ arba $1200{ }^{\circ} \mathrm{C}$ temperatūroje mišinių laiką iki 15 val., kalsilito kiekis sumažèja (nes šis mineralas nèra stabilus) ir formuojasi didesnis termodinamiškai stabilaus leucito kiekis.

2. Nustatyta, kad naudojant didesnio $\mathrm{Al}_{2} \mathrm{O}_{3} / \mathrm{SiO}_{2}$ santykio $(0,89)$ šamoto užpildą, iprastinio ir vidutinio cemento kiekio ugniai atsparaus šamotinio betono eksploatacinès charakteristikos $1100{ }^{\circ} \mathrm{C}$ temperatūroje yra geresnès palyginus su betonais, kuriuose $\mathrm{Al}_{2} \mathrm{O}_{3} / \mathrm{SiO}_{2}$ santykis yra mažesnis $(0,68$ ir 0,44$)$ :

- iprastinis betonas po degimo $1100{ }^{\circ} \mathrm{C}$ temperatūros charakterizuojamas $\sim 9 \%$ mažesniu atviru poringumu (siekia $\sim 22 \%), \sim 7 \%$ didesniu tankiu $\left(2120 \mathrm{~kg} / \mathrm{m}^{3}\right), \sim 38 \%$ didesniu gniuždymo stipriu $(67 \mathrm{MPa})$ ir apie du kartus didesniu terminiu atsparumu (17-20 ciklų).

- panaši tendencija stebima vidutinio cemento kiekio betone: atviras poringumas po jo išdegimo $1100{ }^{\circ} \mathrm{C}$ temperatūroje sumažejo $\sim 7 \%$ ir siekè $\sim 19 \%$, tankis padidejo $\sim 6 \%\left(2210 \mathrm{~kg} / \mathrm{m}^{3}\right)$, gniuždymo stipris $-\sim 78 \%$ (126 MPa), $\sim(20-50) \%$ taip pat padidejo terminis atsparumas (29 ciklai).

3. Nustatyta, kad 2,5\% kvarcinio smèlio priedas dèl polimorfinių pokyčių aukštoje temperatūroje neturi kritinio poveikio ịprastinio betono, modifikuoto $\mathrm{SiO}_{2}$ mikrodulkèmis, terminiam atsparumui. Šio parametro mažejimas siekia tik $\sim 10-15 \%$, priklausomai nuo panaudoto šamoto rūšies.

4. Vertinant ultragarso impulso greičio pokyti betono bandiniuose, nustatyta, kad $1 \%$ metalinès fibros priedo, dèl armavimo efekto, sumažina vidutinio cemento kiekio betonų (kuriuose $\mathrm{Al}_{2} \mathrm{O}_{3} / \mathrm{SiO}_{2}$ 
santykis šamoto užpilde siekia 0,68 ir 0,89 ) destrukciją, kai cikliškai kaitinami ir aušinami betono bandiniai.

5. Nustatytas malto kvarcinio smèlio priedo poveikis ugniai atsparių šamotinių betonų šarminiam atsparumui:

- $1100{ }^{\circ} \mathrm{C}$ priedas turi įtakos blokuojančio kalio skverbimuisi apsauginio barjero formavimuisi betono bandinių paviršiuje, nepriklausomai nuo betono tipo ir naudojamo šamoto užpildo rūšies;

- apsauginio barjero storis po 3 šarminių ciklų, priklausomai nuo betono rūšies, siekia $\sim 700-\sim 1300 \mu \mathrm{m}$;

- šarminis atsparumas siekia ne mažiau 20 ciklų.

6. Rentgenografinè analizè parodè, kad apsauginiame barjere po 3 šarminiu ciklų padidèja amorfinès fazès kiekis ir identifikuojami šie kristalinès būsenos šarminès korozijos produktai: kalsilitas, kubinis leucitas, tetragoninis leucitas, kalio silikatas ir vadeitas. Tikètina, kad kalio silikatas ir papildomas amorfinès fazès kiekis susidaro dèl kalio ir kvarco (kvarcinis smèlis) reakcijos.

7. EDS ir SEM tyrimai parode, kad apsauginis barjeras yra diskretus (netolygus pagal elementinę sudètị). Didejjant šarminių ciklų skaičiui, didejja ne tik jo storis, bet vyksta ir $\mathrm{K}$ prasiskverbimas $\mathfrak{i}$ gilesnius medžiagos sluoksnius. Po 6 šarminio atsparumo ciklų vidutine kalio koncentracija iprastinio betono apsauginiame barjere siekia $\sim 38 \%$, vidutinio cemento betonų serijoje $\sim 24 \%$. Kalio prasiskverbimas stebimas šamotiniame betone, o jo difuzija ị šamoto užpildus, palyginus su matrica, yra minimali.

8. Nustatyta, kad $1200{ }^{\circ} \mathrm{C}$ temperatūroje apsauginis barjeras ịprastiniame betone su kvarcinio smèlio priedu nesusidaro, todèl tokio betono šarminis atsparumas siekia tik 2 ciklus. Šarminio lydalo skverbimąsi ị medžiagą galima paaiškinti poringumo parametrų pakitimu. Nustatyta, kad keliant kaitinimo temperatūrą nuo $1100{ }^{\circ} \mathrm{C}$ iki $1200{ }^{\circ} \mathrm{C}$ atviras poringumas padideja nuo $\sim(22-24) \%$ iki $\sim(23-26) \%$.

9. Vidutinio cemento kiekio betono atviras poringumas $1200{ }^{\circ} \mathrm{C}$ siekia apie $\sim 21 \%$. Pastebèta, jog esant tokiam medžiagos poringumui, apsauginis barjeras, susidaręs vidutinio cemento kiekio betone, yra stabilus $1200{ }^{\circ} \mathrm{C}$ temperatūroje, o betono šarminis atsparumas ne mažesnis nei 5 ciklai.

10. Parinkta vidutinio cemento kiekio ugniai atsparaus betono su šamoto užpildu, kuriame $\mathrm{Al}_{2} \mathrm{O}_{3} / \mathrm{SiO}_{2}$ santykis siekia 0,89 , sudètis gali būti naudojama kieto biokuro šiluminių irrenginių išklojose. Betonas yra atsparus šarminių junginių poveikiui (siekia ne mažiau nei 20 ciklų) ir 
pasižymi šiomis eksploatacinèmis charakteristikomis išdegus $1100{ }^{\circ} \mathrm{C}$ temperatūroje: gniuždymo stipriu $-\sim 130 \mathrm{MPa}\left(1100^{\circ} \mathrm{C}\right)$; tankiu $\sim 2200 \mathrm{~kg} / \mathrm{m}^{3}\left(1100{ }^{\circ} \mathrm{C}\right)$; susitraukimu - 0,3\% (1100 $\left.{ }^{\circ} \mathrm{C}\right)$; terminiu atsparumu $-\sim 30$ ciklų ir panaudojimo temperatūra $-\sim 1450{ }^{\circ} \mathrm{C}$. 


\section{Bendrosios išvados}

1. Šarminio atsparumo, šamoto užpildų tyrimai parodè, kad cikliškai veikiant $\mathrm{K}_{2} \mathrm{CO}_{3} \quad 1100{ }^{\circ} \mathrm{C}$ ir $1200{ }^{\circ} \mathrm{C}$ degimo temperatūrose, nepriklausomai nuo to, koks yra realus $\mathrm{Al}_{2} \mathrm{O}_{3} / \mathrm{SiO}_{2}$ santykis $(0,44 ; 0,68 ; 0,89)$ šamoto užpilde, jie nèra atsparūs šarminei korozijai.

2. Nustatyta, kad naudojant didesnio $\mathrm{Al}_{2} \mathrm{O}_{3} / \mathrm{SiO}_{2}$ santykio $(0,89)$ šamoto užpildą, îprastinio ir vidutinio cemento kiekio ugniai atsparaus šamotinio betono eksploatacinès charakteristikos $1100{ }^{\circ} \mathrm{C}$ temperatūroje yra geresnès palyginus su betonais, kuriuose $\mathrm{Al}_{2} \mathrm{O}_{3} / \mathrm{SiO}_{2}$ santykis yra mažesnis $(0,68$ ir 0,44$)$. Betonai su tokio užpildo santykiu charakterizuojami mažesniu atviru poringumu, didesniu tankiu, gniuždymo stipriu ir terminiu atsparumu.

3. Nustatyta, $\mathrm{kad} 1100^{\circ} \mathrm{C}$ temperatūroje malto kvarcinio smèlio priedas turi ịtakos apsauginio barjero formavimuisi betono bandinių paviršiuje, nepriklausomai nuo betono tipo ir šamoto užpildo rūšies. Dẻl to įprastinio ir vidutinio cemento kiekio ugniai atsparių betonų, šarminis atsparumas siekia ne mažiau 20 ciklų.

4. Nustatyta, kad apsauginiame barjere po 3 šarminių ciklų, palyginus su nepaveiktų betonų, padidèja amorfinès fazès kiekis ir identifikuojami šie kristalinès būsenos šarminès korozijos produktai: kalsilitas, kubinis leucitas, tetragoninis leucitas, kalio silikatas ir vadeitas. Galimai 
kristaliniai ir amorfiniai reakcijos produktai užpildo medžiagos poras ir kapiliarus, kartu formuojant apsauginį sluoksnį ir apsunkinant kalio prasiskverbimą ị gilesnius medžiagos sluoksnius.

5. Identifikuoti atsparesnio šarminei korozijai barjero formavimosi šamotiniuose betonuose, cikliškai veikiant $\mathrm{K}_{2} \mathrm{CO}_{3}$ ir aukštai temperatūrai, ypatumai: barjero zonoje kalis skverbiasi vis gilyn su kiekvienu ciklu; barjero zona sudaryta iš kristalinès ir amorfinès (stiklo) fazès; kalio naujadarų (korozijos produktų) kiekis vis didèja su kiekvienu ciklu. Tai yra pagrindiniai korozijos intensyvumo prognozavimo kriterijai (tiek absoliuti suma $\%$, tiek jos kiekio augimas su ciklais). Visa tai, leidžia vertinti ir barjero stabilumą $1100{ }^{\circ} \mathrm{C}$ temperatūroje veikiant šarminiams korozijos ciklams.

6. Nustatyta, $\mathrm{kad} 1200{ }^{\circ} \mathrm{C}$ temperatūroje apsauginis barjeras ịprastiniame betone su kvarcinio smèlio priedu nèra stabilus. Vidutinio cemento kiekio betone jis susidaro ir yra stabilus 1100 ir $1200{ }^{\circ} \mathrm{C}$ temperatūroje. Šarminio lydalo skverbimąsi į medžiagą galima paaiškinti poringumo parametrų pakitimu. İprastiniame betone, keliant kaitinimo temperatūrą nuo $1100{ }^{\circ} \mathrm{C}$ iki $1200{ }^{\circ} \mathrm{C}$ atviras poringumas padideja nuo $\sim(22-24) \%$ iki $\sim(23-26) \%$, o vidutinio cemento kiekio betone atviras poringumas $1200{ }^{\circ} \mathrm{C}$ yra mažesnis ir siekia apie $\sim 21 \%$. 


\section{Literatūra ir šaltiniai}

Aksel, C. 2003. The effect of mullite on the mechanical properties and thermal shock behaviour of alumina-mullite refractory materials. Ceramics International 29 (2): 183-188.

Alibasic, E.; Oldin, J.; Kannabiran, S.; Yiakoumi, A. 2014. Design of castables and their relevance to alkali resistance applications. 57th International Colloquium on Refractories, Eurogress, 24-25 September, Eurocongress. Aachen 67-69.

Amour, H.; Schiferl, D.; Denner, W.; Schulz, H.; Holzapfel, W. B. 1978. High-pressure single-crystal structure determinations for ruby up to $90 \mathrm{kbar}$ using an automatic diffractometer. Journal of Applied Physics 49: 4411-4416.

Antonovič, V.; Goberis, S.; Pundienè, I.; Stonys, R. 2006. A new generation of deflocculants and microsilica used to modify the properties of a conventional refractory castable based on a chamotte filler, Refractories and industrial ceramics 47 (3): 178-182.

Antonovič, V.; Kerienè, J.; Stonys, R.; Boris, R.; Škamat, J. 2015. Study of the structure and phase composition of the refractory comprising the lining of a boiler operating on solid biofuel, Refractories and Industrial Ceramics. New York: Springer International Publishing 56 (2): 188-193.

Antonovič, V.; Pundienė, I.; Stonys, R.; Čèsnienè, J.; Kerienè, J. 2010 b. A review of the possible applications of nanotechnology in refractory concrete. Journal of civil engineering and management 16 (4): 595-602. 
Antonovič, V.; Pundienė, I.; Stonys, R.; Pyrenkin, O. 2010 a. Study of the effect of type of high-alumina cement on the properties of heat-resistant concrete with a composite deflocculant. Refractories and Industrial Ceramics 51 (4): 279-282.

Antonovič, V.; Stonys, R. 2019. Biokuro katilų konstrukcijų, pagamintų iš ugniai atsparių medžiagų, naudojimo ypatumai. Šilumine technika 1 (75): 20-21.

ASTM C 454-83:2007 Standard practice for disintegration of carbon refractories by alkali. American Technical Standard, 2007.

Balandis, A.; Kantautas, A.; Leskauskas, B.; Vaickelionis, G.; Valančius, Z. 2006. Chemijos inžinerija. I knyga $476 \mathrm{p}$.

Balandis, A.; Leskauskas, B.; Šinkūnas, S.; Vaickelionis, G.; Valančius, Z. 2007. Chemijos inžinerija. II knyga 536 p.

Balzar, D.; Ledbetter, H. 1993. Crystal structure and compressibility of 3:2 mullite. American Mineralogist 78: 1192-1196.

Barkauskas, V.; Stankevičius, V. 1997. Pastatų atitvarų šiluminé fizika. Kaunas 298 p.

Baspinar, M.; Serhat, K. F. 2009. Optimization of the corrosion behavior of mullite refractories against alkali vapor via $\mathrm{ZrSiO}_{4}$ addition to the binder phase. Ceramics - Silikaty 53 (4): 242-249.

Bennet, J. P.; Kwong, K. S.; Oxnard, R. T. 2001. An evaluation of industrial practices for the use reuse-recycling of spent refractory materials. Unitecr 20015 p.

Bennett, J. P.; Kwong, K. S. 2003. Microstructural evaluation of slagging gasifier refractories. Proceedings of Unitecr $200321 \mathrm{~A}-05$.

Bier, T. A.; Parr, C. 1996. Admixtures with calcium aluminate cement and CAC based castables. Lafarge calcium aluminates. Technical paper. Reference F 10/96. 28th Annual Ceramic Society Symposium 9 p.

Bjorn, M.; Bjorn, S. 2015. The Use of Microsilica in Refractory Castables. Elkem ASA Materials, P.O. Box 8126 Vaagsbygd. Kristiansand, Norway N-4602.

Boris, R. 2016. Vidutinio cemento kiekio ugniai atsparaus betono su klinkeriniu užpildu struktūros ir savybiu tyrimai. Daktaro disertacija. Vilnius: Technika $104 \mathrm{p}$.

Brachhold, N.; Aneziris, C. G. 2017. Alkali Corrosion-Resistant heat insulation materials. Refractories worldforum 9 (1): 69-73.

Brunk, F. 2001. Silica refractories. CN Refractories, Spesial Issues 5: 27-30.

Büchel, G.; Buhr, A.; Gierisch, D.; Racher, R. P. 2005. Alkali - and calcium hexaaluminate of dense $\mathrm{CO}$ - resistance Bonite, 48 International Colloquium on Refractories Proceedings 208-214.

Butzbach, K. 2019. Hasle have a long tradition for producing highly alkali resistant refractory castables. Hasle Refractories $1 \mathrm{p}$. 
Caprio, J. A.; Wolfe, H. E. 1982. Refractories for hazardous waste incineration - an overview. National Waste Proceeding Conference, American Society of Mechanical Engineers 139-159.

Carlborg, M.; Boström, D.; Öhman, M.; Backman, R. 2013. Reactions between ash and ceramic lining in entrained flow gasification of wood - exposure studies and thermodynamic considerations. 21st European Biomass Conference and Exhibition 446-449.

Čekanavičius, V.; Murauskas, G. 2004. Statistika ir jos taikymai. II knyga. Vilnius: TEV $272 \mathrm{p}$.

Cellai, D.; Gesing, T. M.; Wruck, B.; Carpenter, M. A. 1999. X-ray study of the trigonalhexagonal phase transition in metamorphickalsilite. American Mineralogist 84: 1950-1955.

Da Luz, A. P.; Braulio, M. A. L.; Pandolfelli, V. C. 2015. Refractory castable engineering. FIRE Compendium Series. Baden-Baden: Göller Verlag GmbH 733 p.

Denisov, D. E.; Popova, M. E.; Maksimov, M. V. 2008. Deflocculated refractory concretes with a high cement content. Refractories and Industrial Ceramics 49 (1): 48-52.

Deutsche Gesellschaft Feuerfest-und Schornsteinbau. 2005. Refractory engineering: materials, design, construction. Publisher Essen Vulkan, Germany 456 p.

Deutsche Gesellschaft Feuerfest-und Schornsteinbau. 2016. Refractory Engineering: materials, design, construction. 3st completely revised edition. Published by Vulkan Verlag $670 \mathrm{p}$.

Didier-Werke, A. G. 1989. Feuerfeste Werkstoffe und ihre Merktale 103 p.

Dominguez, I. R.; Gómez-Millán, J.; Alvarez, M.; Aza De, S.; Contreras. L.; Aza De, A. H. 2010. Build-up formation and corrosion of monolithic refractories in cement kiln preheaters. Journal of the European Ceramic Society 30: 1879-1885.

Dove, M. T.; Cool, T.; Putnis, A.; Palmer, D. C.; Salje, E. K. H.; Winkler, B. 1993. On the role of $\mathrm{Al}-\mathrm{Si}$ ordering in the cubic-tetragonal phase transition ofleucite. American Mineralogist 78: 486-492.

El-Meliegy, E.; Van Noort, R. 2012. Glasses and glass ceramics for medical applications. Springer Science+Business Media $244 \mathrm{p}$.

EN ISO 1893:2009 Refractory products - determination of refractoriness under load differential method with rising temperature. International Standard Organization, 2009 $18 \mathrm{p}$.

Fard, F. G.; Talimian, A. 2014. Improving Corrosion Behaviour of Magnesia-Chrome Refractories by Addition of Nanoparticles. Refractories World Forum 6 (2): 93-98.

Firoozjaei, E. A.; Saidi, A.; Monshi, A.; Koshy, P. 2010. The effect of microsilica and refractory cement content on the properties of andalusite based Low Cement Castables used in aluminum casthouse. Ceramica 56 (340): 411-421.

Fischer, U.; Aneziris, C. G.; Schlegel, E. 2008. Corrosion problems of refractories due to the use of secondary fuels. Refractories Manual 28-33. 
Geith, M.; Majcenovic, C.; Wiry, A. 2001. Special impregnation of alumina bricks to increase the alkali resistance. Vienna, Austria: RHI Refractories 54 (11): 638-645.

Goberis, S. 2003. Thermal stability of unshaped refractory materials. Refractories and Industiral Ceramics 44 (62): 427-430.

Goberis, S.; Antonovič, V. 2004. Improving the structure and properties of a refractory castable containing porous chamotte fillers, Refractories and industrial ceramics 45 (6): 446-449.

Goberis, S.; Antonovič, V. 2007. Kaitrai atsparūs šamotbetoniai: Monografija. Vilnius: Technika 360 p.

Goodwin, D. W.; Lindop, A. J. 1970. The crystal structure of $\mathrm{CaO} \cdot 2 \mathrm{Al}_{2} \mathrm{O}_{3}$. Acta Crystallographica, Section B 26: 1230-1235.

Goswami, G.; Sanu, P.; Panigrahy, P. K. 2015. Estimation of thermal expansion of silica refractory based on its mineralogy, Interceram 64, Refractories Manual II 174-176.

Greaves, C. 1983. A powder neutron diffraction investigation of vacancy ordering and covalencein gamma- $\mathrm{Fe}_{2} \mathrm{O}_{3}$. Journal of Solid State Chemistry 49: 325-333.

Hayashi, T.; Shibuno, M. 1979. Shingawa Technical Report 23 (11).

Hirose, T.; Kihara, K.; Okuno, M.; Fujinami, S.; Shinoda K. 2005. X-ray, DTA and Raman studies of monoclinic tridymite and its highertemperature orthorhombic modification with varying temperature. Journal of Mineralogical and Petrological Sciences 100: 55-69.

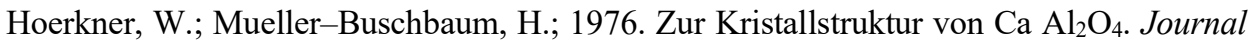
of Inorganic and Nuclear Chemistry 38: 983-984.

Jacob-Lopes, E.; Zepka, L. Q. 2017. Frontiers in bioenergy and biofuels. Printed in Croatia. $511 \mathrm{p}$.

Jacobson, N. S.; Fox, D. S.; Opila, E. J. 1998. High temperature oxidation of ceramic matrix composites. Journal of pure and applied chemistry 70: 493-500.

Jansenboiler.com. 2020. http://jansenboiler.com/project-capabilities/biomass-boilerupgrades [Žiūrèta 2020-01-17] 1 p.

Jefimovas, A. 2015. Statybinès medienos pirolizinis anglëjimas. Daktaro disertacija. Vilnius: Technika $111 \mathrm{p}$.

Jenkins, B. M.; Baxter, L. L.; Miles Jr. T. R.; Miles, T.R. 1998. Combustion properties of biomass. Fuel Processing Technology 54: 17-46.

Jesse, J.; Brown, Jr. 1995. Phase Diagrams in Advanced Ceramics. The Use of Phase Diagrams to Predict Alkali Oxide Corrosion of Ceramics 237 p.

Kerienė, J. 2014. Chemija. Vilnius: Technika 363 p.

Khlystov, A.; Konnov, M.; Shirokov, V. 2017. Resource and energy saving technologies of refractory linings of thermal units, MATEC Web of Conferences 106: (06011) 1-7.

Kihara, K. 1990. An X-ray study of the temperature dependence of the quartz structure. European Journal of Mineralogy 2: 63-77. 
Klinger, W.; Weber, W.; Zimmermann, H. 2007. Application concepts of shaped and unshaped refractories for combustion plants, Proceedings of Unitecr 440-443.

Kobayashi, W. T.; Paulo, S.; Da Silva, E. L.; Carlos, S.; Paskocimas, C. A. 2003. Method for producing corrosion resistant refractories. United States Patent. No.: US 6,667,074 B2.

Lee, W. E.; Zhang, S. 1999. Melt corrosion of oxide and oxide-carbon refractories, Journal International Materials Reviews 44 (3):77-104.

Leupold, H.; Santowski, K.; Wieland, K. 1984. Improvement of Resistance to Alkali Attack of Refractory Materials of the $\mathrm{SiO}_{2} \mathrm{Al}_{2} \mathrm{O}_{3}$ System for temperatures up to $1300{ }^{\circ} \mathrm{C}$ in Rotary Cement Kilns. Interceram 33: 29-32.

Li, N.; Vainio, E.; Hupa, L.; Hupa, M.; Zabetta, E. C. 2017. High-Temperature Corrosion of Refractory Materials in Biomass and Waste Combustion: Method Development and Tests with Alumina Refractory Exposed to a $\mathrm{K}_{2} \mathrm{CO}_{3}-\mathrm{KCI}$ Mixture. American Chemical Society, Energy Fuels 31 (9): 10046-10054.

Lietuvos energetikos asociacijos ataskaita. 2013. Biokuro potencialo Lietuvoje ịvertinimas, biokuro kainų prognozė, biokuro panaudojimo socialinès naudos ivertinimas ir biokuro panaudojimo plètrai reikalingų valstybès intervencijų pasiūlymai. Lietuvos agrariniu ir mišku mokslu centras ir Aleksandro Stulginskio universitetas. Prieiga per internetą: http://www.biokuras.lt/uploads/new_assigned_files/str.pdf [Žiūrèta 2019-09-16] 12 p.

Lietuvos Respublikos atsinaujinančių išteklių energetikos įstatymas, Nr. XI-1375, (Žin., 2011, Nr. 62-2936), Valstybès žinios, 2020-05-31. Prieiga per internetą: https://eseimas.lrs.lt/portal/legalAct/lt/TAD/TAIS.398874 [Žiūrèta 2017-10-13] 64 p.

Liukaitis, J.; Kleveckas, T. 2006. Medžiagų tyrimo pagrindai. Kaunas: Technologija. 76 p.

Loison, L.; Tonnesen, T.; Telle, R.; Bilbao, E.; Poirier, J.; To, E. 2017. Corrosion resistance of hibonite based low cement castable against biomass slag, Proceedings of Unitecr. $418-421$.

Lou, V. L. K.; Heuer, A. H. 1990. Graphical displays of the thermodynamics of high temperature gas-solid reactions and their applications, in high temperature corrosion of technical ceramics, edited by R. J. Fordham. Elsevier Applied Science 33-52.

LST EN 196-6:1996 Cementas. bandymo metodai. 6 dalis. smulkumo nustatymas. Vilnius, $19966 \mathrm{p}$.

LST EN ISO 10545-3:2000 Keraminès plytelès. 3 dalis. Vandens i̇mirkio, tariamojo poringumo, tariamojo santykinio tankio ir tankio nustatymas. Vilnius, $20006 \mathrm{p}$.

LST EN ISO 1927-2:2013 Monolitiniai (neforminiai) ugniai atsparūs gaminiai. 2 dalis. Ėminiu émimas bandymams. Vilnius, 2013.

LST EN ISO 1927-3:2013 Monolitiniai (neforminiai) ugniai atsparūs gaminiai. 3 dalis. Gautu medžiagu apibūdinimas. Vilnius, 2013.

LST EN ISO 1927-4:2013 Monolitiniai (neforminiai) ugniai atsparūs gaminiai. 4 dalis. Kaitrai atsparaus betono konsistencijos nustatymas. Vilnius, 2013. 
LST EN ISO 1927-5:2013 Monolitiniai (neforminiai) ugniai atsparūs gaminiai. 5 dalis. Bandiniu paruošimas ir apdorojimas. Vilnius, 2013.

LST EN ISO 1927-6:2013 Monolitiniai (neforminiai) ugniai atsparūs gaminiai. 6 dalis. Fizikiniu savybiu matavimas. Vilnius, 2013.

LST EN ISO 1927-7:2013 Monolitiniai (neforminiai) ugniai atsparūs gaminiai. 7 dalis. Suformuoty elementu bandymai. Vilnius, 2013.

LST EN ISO 1927-8:2013 Monolitiniai (neforminiai) ugniai atsparūs gaminiai. 8 dalis. Papildomujų savybių nustatymas. Vilnius, 2013.

Luis, A. M. S.; Elson, L.; Jose, A. V. 1990. Potassium Vapor Attack in Refractories of the Alumina-Silica System. Journal of the American Ceramic Society 73 (5): 1413-1416.

Mačiulaitis, R. 1996. Fasadinès keramikos atsparumas šalčiui ir ilgaamžiškumas. Vilnius: Technika. $132 \mathrm{p}$.

Mačiulaitis, R.; Malaiškienè, J. 2012. Statybinès keramikos charakteristiku ir technologiniu parametru reguliavimo galimybès: Monografija. Vilnius: Technika $184 \mathrm{p}$.

Martinėnas, B. 2004. Eksperimento duomenu statistine analizé. Vilnius: Technika 101 p.

Martinovic, S.; Majstrović, J.; Vidojković, V.; Volkov-Husovic, T. 2009. Preparation and properties of low cement castable sintered at different temperatures \#. Processing and Application of Ceramics 3 (4): 191-196.

Maruyama, S.; Tsuda, H.; Motoki, E. 2011. Recycling technology of used refractories. Proceedings of Unitecr $20114 \mathrm{p}$.

Medri, V.; Fabbri, S.; Ruffini, A.; Dedecek, J; Vaccari, A. 2011. SiC-based refractory paints prepared with alkali aluminosilicate binders, Journal of the European Ceramic Society 31 (12): 2155-2165.

Narita, K.; Onoye, T.; Satoh, Y.; Miyamoto, M.; Taniguchi, K.; Kamatani, S.; Sato, T.; Fukihara, S. 1981. Effects of Alkalis and Zinc on the Wear of Blast Furnace Refractories and the Tuyere Displacement. Transactions of the Iron and Steel Institute of Japan 36: 733-740.

Nishikawa, A. 1984. Technology of monolithic refractories. Japan: Japan by Toppan Printing Company, Ltd 598 p.

Niyogi, S. K.; Das, A. C. 1994. Prediction of thermal shock behavior of castable refractories by sonic measurements. Refractories 43: (6) 453-457.

Novošinskas, H. 2012. Inžineriniu technologijų projektavimas. Mokomoji knyga. Akademija 117 p.

Palmer, D. C.; Dove, M. T.; Ibberson, R. M.; Powell, B. M.1997. Structural behavior, crystal chemistry and phase transitions in substitutedleucites: High-resolution neutron powder diffraction studies sample. American Mineralogist 82: 16-29.

Parr, C.; Simonin, F.; Touzo, B.; Wohrmeyer, C.; Valdelievre, B.; Namba, A. 2004. The impact of calcium aluminate cement hydration upon the properties of refractory castable. 
Kerneos Aluminate Technologies. Technical Paper. Reference TP-GB-RE-LAF-043 $1-17$ p.

Peacor, D. R. 1973. High-temperature single-crystal study of the cristobalite inversion. Zeitschrift fur Kristallographie 138: 274-298.

Perkoa, J.; Zarzuelab, R.; Garcia-Lodeiroc, I.; Blanco-Varelac M. T.; Mosquerab, M. J.; Seemannd, T.; Yua, L. 2020. The importance of physical parameters for the penetration depth of impregnation products into cementitious materials: Modelling and experimental study. Construction and Building Materials 257: 1-11.

Pitac, N. V.; Shapalov, V. S.; Azarenkova, L. E.; Privalova, N.; G. 1991. Influence of carbon monoxide and its decomposition catalysts on the destruction of blast-Furnace aluminosilicate refractories, Plenum Publishing Corporation 32: 578-584. Translated from Ogneupory 11: 18-22.

Poirier, J. 2019. Corrosion of $\mathrm{SiC}$ refractories by molten salts, fundamental aspects and industrial applications: Incineration and aluminium industry. Chemht CNRS-UPR3079, University of Orleans, 1D Avenue de la recherché Scientifique, Orleans. International Colloquium on Refractories 2019 - Supplier Industries enabling Refractories. $45071 \mathrm{Fr}$. $62^{\text {nd }}$.

Poirier, J.; Bouchetou, M. L.; Qafssaoui, F.; Ildefonse, J.; P. 2008. Analysis and interpretation of refractories microstructures in studies of corrosion mechanisms by liquid oxides. Journal of the European Ceramic society 28 (8): 1557-1568.

Poirier, J.; Gaubil, M.; Rigaud, M. 2017. Corrosion of Refractories - The Impact of Corrosion. FIRE Compendium Series 2C $440 \mathrm{p}$.

Poirier, J.; Rigaud, M. 2017. Corrosion of Refractories - Testing and Characterization Methods. FIRE Compendium Series 2B 280 p.

Poirier, J.; Rigaud, M. 2017. Corrosion of Refractories: The Fundamentals. FIRE Compendium Series 2A $454 \mathrm{p}$.

Prigent, P.; Bouchetou, M. L.; Poirier, J. 2011. Andalusite: An amazing refractory raw material with excellent corrosion resistance to sodium vapours. Ceramics International 37 (7): 2287-2296.

Pundienè, I.; Antonovič, V.; Stonys, R. 2010. Hybrid deflocculant on hardening process of refractory MCC-type castable, Ceramics materials, Kraków: Polskie Towarzystwo Ceramiczne PTCer 62 (3): 382-385.

Putz, H.; Brandenburg, K. 2020. Match! - Phase Analysis using Powder Diffraction Version 3.11, Bonn, Germany. Crystal Impact 147 p.

Raaz, F. 1930. Ueber den Feinbau des Gehlenit. Ein beitrag zur kenntnis der melilithe, sitzungsberichte der akademie der wissenschaften in wien, mathematischnaturwissenschaftliche klasse, abteilung 1: mineralogie, biologie, erdkunde 139: 645-672.

Ragelienè, L.; Mickevičius, D. 2011. Fizikinè chemija. Praktiniai darbai. Vytauto Didžiojo universitetas. Kaunas 218 p. 
Ren, B.; Shaobai, S.; Yawei, L.; Shengli, J. 2015 a. Correlation of pore structure and alkali vapor attack resistance of bauxite-SiC composite refractories. Ceramics International 41 (10): 14674-14683.

Ren, B.; Shaobai, S.; Yawei, L.; Yibiao, X. 2015 b. Effects of oxidation of SiC aggregates on the microstructure and properties of bauxite- $\mathrm{SiC}$ composite refractories. Ceramics International

41 (2): 2892-2899.

Resende, W. S.; Pinho, M. F.; Paskocimas, C. A.; Oliveira Brito, H. L.; Longo, E. 2001. Mullite-refractory resistant to alkali and ceramic glazes $200112 \mathrm{p}$.

Rezaee, M.; Mousavi, K. S. M.; Liu, K. H. 2011. The role of brookite in mechanical activation of anatase to rutile transformation of nano crystalline $\mathrm{TiO}_{2}$ : An XRD and Raman spectroscopy investigation. CrystEngComm 13 (16): 5055.

Rezaie, A.; Moore, R. E.; Velez, M.; Davis, W. A.; Fahrenholtz, W.; Headrick, W. L. 2004. Interaction of Refractories and Alkaline Containing Corrodants. Refractories Applications and News. American Ceramic Society. [Žiurèta 2020-02-03]. Prieiga per internetą: https://scholarsmine.mst.edu/matsci_eng_facwork/127.

Riedl, R.; Dahl, J.; Obernberger, J.; Narodoslawski, M. 1999. Corrosion in fire tube boilers of biomass combustion plants. Proceedings of the China International Corrosion Control Conference. Paper Nr. 90129 1-5.

Sadik, C.; Amrani, El. I. E.; Albizane, A. 2014. Recent advances in silica-alumina refractory: A review. Journal of Asian Ceramic Societies 2 (2014): 83-96.

Schaafhausen, S.; Yazhenskikh, E.; Walc, A.; Heidenreich, S.; Müller M. 2013. Corrosion of alumina and mullite hot gas filter candles in gasification environment. Journal of the European Ceramic Society 33 (15-16): 3301-3312.

Schlegel, E. 2008. Evaluation of phase diagrams with regard to the alkali corrosion of refractories. Silikaty $5 \mathrm{p}$.

Schnabel, M.; Buhr, A.; Büchel, G.; Kockegey-Lorenz, R.; Dutton J. 2011. Advantages of calcium hexaaluminate in a corrosive environment. Refractories Worldforum 3: 87-94.

Scudeller, L. A. M.; Longo, E.; Varela, J. A. 1990. Potassium Vapor Attack in Refractories of the Alumina-Silica System, Journal American Ceramic Society 36: (733-740).

Šiaučiūnas, R.; Štuopys, A. 1998. Ugniai atsparios medžiagos. Vadovėlis. Kaunas: Technologija. $278 \mathrm{p}$.

Sigmathermal.com. 2020. https://www.sigmathermal.com/products/biomass-energysystems [Žiūrèta 2020-01-29].

Simon, F. G.; Adamczyk, B.; Kley, G. 2003. Refractory materials from waste. Materials Transactions 44 (7): 1251-1254.

Skripkiūnas, G. 2007. Statybiniu konglomeratų struktūra ir savybès. Kaunas, Technologija $336 \mathrm{p}$. 
Slovikovskii, V.; Gulyaeva, A. 2016. Corrosion-Erosion-Resistant Carbon-Containing Refractories for Nonferrous Metallurgy Units. Refractories and Industrial Ceramics 56 (5): 490-493.

Sodium and potassium silicates: Versatile compounds for your application. PQ Europe, Netherlands. 2004. 16 p. https://www.pqcorp.com/docs/default-source/recommendedliterature/pq-corporation/lithium-silicate/sodium-and-potassium-silicates-brochure-engoct-2004.pdf?sfvrsn=d22426fb_3 [Žiūrèta 2019-03-15].

Soltan, A. M.; Pollmann, H.; Kaden, R.; Konig, A.; Abd, EL-R. F.; Eltaher, M.; Serry, M. 2015. Degradation of aluminosilicate refractories: An integrated approach. Journal of the European Ceramic Society 35 (16): 4573-4592.

Stjernberg, J.; Olivas-ogaz, M. A.; Antti, M. L.; Ion, J. C.; Lindblom, B. 2013. Laboratory scale study of the degradation of mullite/corundum refractories by reaction with alkalidoped deposit materials. Ceramics International 39 (1): 791-800.

Surendranathan, A. O. 2015. An Introduction to Ceramics and Refractories, by Taylor \& Francis Group, LLC 479 p.

Swanson, D. K.; Prewitt, C. T. 1983. The crystal structure of $\mathrm{K}_{2} \mathrm{SiSi}_{3} \mathrm{O}_{9}$ Note: $\mathrm{B}(1,2)$ for K and $\mathrm{Si}$ have been changed to match symmetry constraints. American Mineralogist 68: 581-585.

Szczerba, J.; Boczoń, A.; Studencka, B. 2005. Studies of impact of alkali salts on alumina based castables without additives and with them. Ceramika 88: 158-172.

Tassot, P.; Webb-Janich, M.; Hawecker, M. 2003. New refractory solutions for the cement industry. Proceedings in Unitecr 2003: 35-38.

Traore, K.; Kabre, T. S.; Blanchart, P. 2003. Gehlenite and anorthite crystallisation from kaolinite and calcite mix. Ceramics International. 29 (4) 2003: 377-383 p.

Vares, V.; Kask, U.; Muiste, P.; Pihu, T.; Soosaar, S. 2007. Biokuro naudotojo žinynas. Vilnius: Žara 168 p.

Vektaris B.; Vilkas V. 2006. Betono sulfatiné ir šarmine korozija, atsparumas šalčiui ir karbonizacijai. Tyrimai ir prevencinès priemonès. Monografija. Kaunas, Technologija $163 \mathrm{p}$.

Wainwright, J. E.; Starkey J.1971. A refinement of the structure of anorthite. Zeitschrift fuer kristallographi, kristallgeometrie, kristallphysik, kristallchemie (-144,1977) 133: 75-84.

Wöhrmeyer, C.; Parr, C. 2006. The optimisations of deflocculated high cement castables (HCC). Presented at the 49th International Colloquium on Refractories. Eurogrcss Aachen $7-8$.

Xu, H.; Navrotsky, A.; Balmer, M. L.; Su, Y. 2005. Crystal-chemical and energetic systematics of wadeite-type phases. Physics and Chemistry of Minerals 32: 426-435.

Zabolotsky, A. V. 2011. Modeling of the temperature field of the casting ladle lining. Journal of Engineering Physics and Thermophysics 84 (2): 342-347. 
Zevenhoven-Onderwater, M.; Backman, R.; Skrifvars B. J.; Hupa, M. 2001. The ash chemistry in fluidised bed gasification of biomass fuels. Part I: predicting the chemistry of melting ashes and ash-bed material interaction. Fuel first 80: 1489-1502.

Zhao, Y.; Cheng, G.; Long, F.; Liu, L.; Dong, C.; Wang, X.; Zhao, Jin. 2018. Analysis and Prediction of Corrosion of Refractory Materials by Potassium during Biomass CombustionThermodynamic Study. Materials 11 (12): 258412 p.

Адамсон, А. 1979. Физическая химия поверхностей. Москва Мир 568 р.

Гоберис, С.; Антонович, В. 2003. Монолитная футеровка топок, работающих на древесном топливе, Новые огнеупоры 9: 13-15.

ГОСТ 20910-2019. Межгосударственный стандарт. Бетоны жаростойкие. Технические условия 201922 p.

ГОСТ 20910-90:1991. Бетоны жаростойкие. Технические условия. Государственный стандарт. Москва. 199118 р.

Замятин, С. Р.; Пургин, А. К.; Хорошавин, Л. Б.; Цыбин, И. П.; Кокшаров, В. Д. 1982. Огнеупорные бетоны $192 \mathrm{p}$.

Кащеев, И. Д.; Стрелов, К. К.; Мамыкин, П. С. 2007. Химическая технология огнеупоров: учебное пособие. Москва: Интермет Инжиниринг 752 p.

Корнеев, В.; И.; Данилов, В. В. 1991. Производство и применение растворимого стекла. Жидкое стекло - Л.: Стройиздат. 176 р.

Лыков, А. В. 1978. Тепломассообмен: справочник. Москва: Энергия 480 р.

Мачюлайтис, Р. 1997. Морозостойкость и долговечностьизделий фасадной керамики. Вильнюс: Техника 307 р.

Пономаренко, А. А.; Кормина, И.; В. 2019. Дифлокулянт полипласт ЗМБ-RС для неформаваных огнепоров. Новые огнеупоры 12: 13-18.

Роучка, Г.; Вутнау, Х. 2010. Огнеупорныле материальл. Структура, свойства, испьтания: справочник. Перевод с немецкого. Интермет Инжинеринг 392 р.

Сена, Л. А. 1977. Единицы физических величин и их размерности. Издательство «Наука» 336 p.

Соков, В. Н. 2015. Создание огнеупорных бетонов и теплоизоляционных материалов с повышенной термостойкостью: монография. М.:МГСУ. 288 р.

Фролов, Ю. Г. 1982. Курс коллоидной химии. Поверхностные явления и дисперсные системы. Химия 400 р.

Шишков, И. А.; Айзенберг, А. А.; Бельский, В. И. 1978. Сооружение промышленных печей. Стройиздат 416 р. 


\section{Autoriaus mokslinių publikacijų disertacijos tema sąrašas}

\section{Straipsniai recenzuojamuose mokslo žurnaluose}

Antonovich, V.; Zdanevicius, P.; Stonis R.; Spudulis E.; Korjakins A.; Shakhmenko G.; Tatarinov A. 2020. Study on the destruction of heat-resistant chamotte concrete during sharp heating and cooling, Refractories and industrial ceramics. New York: Springer Science+Business Media. 61 (3): 326-331. ISSN 1083-4877. eISSN 1573-9139.

Zdanevičius, P.; Antonovič, V.; Boris, R.; Stonys, R.; Šukys, R.; Witek, J. 2019. Study of modified heat-resistant concrete in relation to type of chamotte filler, Refractories and industrial ceramics. New York: Springer. 59 (6): 628-632. ISSN 1083-4877. eISSN 1573-9139.

Boris, R.; Antonovič, V.; Kerienè, J.; Stonys, R.; Kudžma, A.; Zdanevičius, P. 2017. Study of alkali resistance of refractory materials used in boilers operating on wood fuel, Refractories and industrial ceramics. New York: Springer Science+Business Media. 57 (6): 651-654. ISSN 1083-4877. eISSN 1573-9139. 


\section{Straipsniai kituose leidiniuose}

Antonovič, V.; Zdanevičius, P.; Boris, R.; Stonys, R.; Witek, J. 2019. Investigation of alkali resistance of fireclay castable with silica sand additive, ICR International Colloquium on Refractories Supplier industries enabling refractories, September 25 th and 26th, EUROGRESS Aachen, Germany: ECREF European Centre for Refractories gemeinnützige. ISBN 9783981581355. 126-129. 


\section{Summary in English}

\section{Introduction}

\section{Formulation of the problem}

Refractory materials belonging to the aluminium silicate $\left(\mathrm{Al}_{2} \mathrm{O}_{3}-\mathrm{SiO}_{2}\right)$ system are not sufficiently resistant to alkali corrosion at high temperatures. Alkali corrosion of such substances is usually caused by potassium/sodium oxides and their salts resulting from the combustion of alternative fuels (including wood).

Alkali corrosion occurs due to reactions of the aluminium silicate substance with alkali metal vapour, melt or alkali compounds in a solid state. Various corrosion products (leucite, kalsilite, feldspars and etc.) are produced with a higher volume than the initial volume of the substance. In cases where melt penetrates the structure of the material, changes in structures occur. The resulting stresses between the initial and changed structure zones, as well as material destructions, take place.

In order to increase the resistance of aluminium silicate refractory castable to alkali corrosion, additives may be used to stimulate the formation of a barrier that prevents the penetration of alkali melt into the structure of the material. For this purpose, a ground quartz sand additive has been used in this work. When using ground quartz sand in fireclay castable, the barrier formation parameters, properties and its stability under thermal loads are unclear. 


\section{The relevance of the thesis}

The usage of wood fuel in boiler plant equipment is widely spread in Europe and Lithuania.

The durability of conventional fireclay refractories in this type of solid biofuel equipment, which belong to the group of aluminium silicate materials and are widely used in industrial furnaces, is not high due to alkali corrosion (sometimes only 1-2 years). The choice of these materials is often determined by the price, which is significantly lower compared to alkali resistant materials with silicon carbide, chromium or zirconium oxides.

Additives that inhibit with or restrict contact with alkali compounds can significantly increase the alkali resistance of conventional fireclay and other aluminium silicates. Improvement of the properties of the material by means of modifying additives and thereby the increase of the lifetime of equipment linings will reduce the need for materials necessary to produce them as well as the need for repair and maintenance works.

\section{The object of the research}

Refractory castable with fireclay fillers for the lining of solid biofuel boiler plant equipment.

\section{The aim of the thesis}

Increase the alkali resistance of refractory castable with fireclay filler for solid biofuel equipment at temperatures between $1100{ }^{\circ} \mathrm{C}-1200^{\circ} \mathrm{C}$.

\section{The objectives of the thesis}

1. Assess alkali resistance of different $\mathrm{Al}_{2} \mathrm{O}_{3} / \mathrm{SiO}_{2}$ ratio $(0,44 ; 0,68 ; 0,89)$ fireclay fillers at temperatures between $1100{ }^{\circ} \mathrm{C}$ and $1200{ }^{\circ} \mathrm{C}$;

2. Identify the physical, mechanical and thermal characteristics of conventional and medium cement refractory fireclay castable with a different $\mathrm{Al}_{2} \mathrm{O}_{3} / \mathrm{SiO}_{2}$ ratio fireclay filler and quartz sand additive;

3. Examine the alkali resistance of conventional and medium cement refractory castable with quartz sand additive at temperatures between $1100{ }^{\circ} \mathrm{C}$ and $1200{ }^{\circ} \mathrm{C}$ and identify the characteristics of the formation of an alkali corrosion resistant barrier.

\section{Research methodology}

The preparation and thermal treatment of refractory castable samples has been carried out in accordance with the requirements of the standard LST EN ISO 1927-(5): 2013. 
The main characteristics of refractory castable in this work were determined on the basis of LST EN ISO 1927-(4,6-8): 2013 standards. Scanning electronic microscopy, $\mathrm{X}$-ray and ultrasound analysis methods were used to assess the structure of the material. Thermal shock resistance of refractory castable was determined according to GOST 20910 2019, open porosity according to LST EN ISO 10545-3: 2000, refractoriness under load according to EN ISO 1893: 2009, alkali resistance by crucible method according to ASTM C 454-83: 2007 standards. The destruction of castable due to sharp heating and cooling has been assessed according to the "one-side heating" method developed in the workflow.

\section{The scientific novelty of the thesis}

In the course of preparation of the thesis, the following results innovative for material engineering science were obtained:

1. The addition of ground quartz sand at $1100{ }^{\circ} \mathrm{C}$ has been shown to increase the alkali resistance of conventional and medium cement refractory fireclay castable by creating a resistant barrier to alkali corrosion regardless of the $\mathrm{Al}_{2} \mathrm{O}_{3} / \mathrm{SiO}_{2}$ ratio in the fireclay filler, without breaking up other performance. This shows that ground quartz sand can also be a universal tool for increasing alkali resistance of other types of aluminium silicates castables.

2. For the first time it has been established that the protective barrier consists of amorphous/glass compounds and crystalline-phase minerals. The crystalline phase prevails over the amorphous phase. The barrier is characterised by discretion (inequality in elemental composition). For each cycle, glass compounds and crystalline minerals are melted in fireclay castable at $1100{ }^{\circ} \mathrm{C}$ during exposure to potassium carbonate. In addition to the formation of amorphous phase in the castable surface reaction zone, crystalline corrosion products are formed in response to the minerals identified with potassium. In the case of more alkali resistant castable, the amount of amorphous phase is decreasing and the amount of crystalline corrosion products for less alkali resistance castable is increasing. During cyclical exposure, in addition to the amorphous phase of glass, crystalline corrosion products gradually close the dominant pores and capillaries of material. In this way, we can quantify the stability of the barrier and predict the resistance of the castable to alkali corrosion.

\section{The practical value of the research findings}

New compositions of conventional and medium cement fireclay castables are recommended for use in the production of solid biofuel boiler plant equipment linings instead of traditional fireclay materials. At the same time, this will make it possible to increase the durability of the internal structures of such installations.

\section{Defended statement}

Irrespective of the $\mathrm{Al}_{2} \mathrm{O}_{3} / \mathrm{SiO}_{2}$ ratio in the fireclay filler, a protective barrier is formed in conventional and medium cement castable with a ground quartz sand additive under the influence of alkali (potassium) melt, which increases the alkali resistance of fireclay castable. 


\section{The approval of the research findings}

Four research articles have been published on the topic of the dissertation: three articles in scientific journals indexed in the Clarivate Analytics Web of Science database and one article in other peer reviewed scientific journals.

The results of the research carried out in the thesis were publicized at 6 scientific conferences in Lithuania and abroad:

- The Conference of Young Scientists "Science - the Future of Lithuania" 2017, 2018, 2019 Vilnius.

- "International Conference on Refractory and Metallurgy (ICRM-2018)", 2018, Russia.

- "62nd International Colloquium on Refractories", 2019, Germany.

- XVIII International Scientific Conference "Refractory materials: Manufacture, methods of testing, application“, 2019, Poland.

\section{The structure of the thesis}

The thesis includes the introduction, three chapters, the general conclusions, the list of references, the list of publications by the author of this thesis and four annexes.

The Thesis consists of 110 pages, excluding the annexes; the text of the thesis contains, 16 numbered formulas, 41 figures and 10 tables. The thesis has been prepared with reference to 150 research sources.

\section{The analysis of scientific research works on alkali corrosion of refractory materials and prevention measures}

The internal structures (linings) of solid biofuel boiler plant equipment such as furnaces and boilers using modern combustion technologies are subject to high temperatures, alkali melt and vapours resulting from fuel combustion, thermal shocks (stopping and starting the equipment), abrasive particulate flow, mechanical loads (cleaning ash and slag), etc.

The research literature analysis showed that aluminium silicate (including fireclay) materials are not resistant to alkali corrosion at high temperatures. For solid biofuels, the use of fireclay materials in equipment often leads to abrupt destruction of the lining. This occurs when the local temperature in heat equipment exceeds the operating temperature of $1100{ }^{\circ} \mathrm{C}$ and the ash melting point is reached. Corrosion is caused by reactions of aluminium silicate material with alkali vapour, melt or solid alkali compounds. Various corrosion products (leucite, kalsilite, feldspars, etc.) are produced with a higher volume than the initial volume of the substance. E. Schlegel points out that the volume in fireclay can increase by up to $19 \%$ when the content of penetrated $\mathrm{K}_{2} \mathrm{O}$ is around $32 \%$. Alkali compounds react first with the amorphous phase of the fireclay and then with mullite. M. Carlborg found that alkali metal ions are the easiest to penetrate the matrix, accumulate there before reacting with a filler.

The application of impregnating technology, additives to reduce the porosity of the material and the size of the pores, as well as additives to promote the formation of a protective barrier, as well as the use of additives with other effects, may be used to increase the resistance of fireclay (and other aluminium silicate) refractories to alkali corrosion. 
Ground quartz sand belongs to a group of additives whose additives may influence the formation of a barrier resistant to alkali corrosion on the surface of the material and interfere with the penetration of alkali compounds into the structure of the refractory material. However, the effect of such an additive on the performance of aluminium silicate castable (in particular thermal shock resistance), the unclear parameters for the formation of the barrier, its characteristics and stability under operational loads (high temperature, thermal shocks) are unclear. It is also unclear how the resistance to alkali corrosion will change with conventional and medium cement castable with fireclay filler of different $\mathrm{Al}_{2} \mathrm{O}_{3} / \mathrm{SiO}_{2}$ ratios and the use of ultradispersed $\mathrm{SiO}_{2}$ (microsilica) and $\mathrm{Al}_{2} \mathrm{O}_{3}$ additives in the castable matrix.

When improving the resistance of refractory concrete to alkali corrosion, account should also be taken of the recommendations of the researchers on other characteristics. For example, W. Klinger's work indicates that in solid biofuel boiler plants, the performance of fireclay concrete must be consistent with the following indicators: cold crushing strength $\geq 60 \mathrm{MPa}$, density $\geq 2200 \mathrm{~kg} / \mathrm{m}^{3}$, thermal chock resistance $\geq 30$ cycles according to DIN 51068/1.

\section{Materials and research methods of the refractory castable}

The used principal materials are the following: calcium aluminate cement (CAC70) Gorkal 70 mark, $\mathrm{Al}_{2} \mathrm{O}_{3} \geq 70 \%$, "Górka Cement" (Poland), CAC40 - ISTRA 40 mark, $\mathrm{Al}_{2} \mathrm{O}_{3} \geq 40 \%$, "Calucem GmbH” (Germany); microsilica - "RW-Fuller” mark, $\mathrm{SiO}_{2}$ $\sim 96.1 \%$, "RW Silicium GmbH" (Germany); reactive alumina CTC 20 mark, $\mathrm{Al}_{2} \mathrm{O}_{3}$ $\sim 99.7 \%$ and calcined alumina - CT 19 mark, $\mathrm{Al}_{2} \mathrm{O}_{3} \sim 99.8 \%$, "Almatis" (Germany); ground fireclay - made of BOS 125 , BOS 135, BOS 145 mark fireclay, accordingly $\mathrm{Al}_{2} \mathrm{O}_{3} \sim 26 \%, \sim 37 \%$ and $\sim 44 \%$, "Tabex-Ozmo", (Poland); ground quartz sand, $\mathrm{SiO}_{2}$ 99.2\%, AB "Anykščių kvarcas" (Lithuania); deflocculants: Castament FS20, "BASF Construction Solutions GmbH" (Germany) and sodium tripolyphosphate (technical). Fireclay filler - BOS 125, BOS 135, BOS 145 mark, maximum grain size $-4 \mathrm{~mm}$. Steel fibre - C-MIX 25-0.4-304 mark "SILICON USA Inc", length - $25 \mathrm{~mm}$, diameter - 0,4 mm. Chemical reagent $-\mathrm{K}_{2} \mathrm{CO}_{3}-99,0 \%$ produced by "Sigma Aldrich" (USA) was also used.

In this work, the main properties of refractory castable have been identified with reference to LST EN ISO 1927-(4,6-8): 2013 standards. The open porosity of castable has been determined according to the standard LST EN ISO 10545-3: 2000. refractoriness under load has been determined by PN-EN ISO 1893: 2009. Thermal shock resistance of the refractory castables has been examined with reference to the provisions of standard GOST 20910-2019. For the assessment of the alkali resistance of castable, the methods of crucible (Fig. S2.1) (ASTM C 454-83: 2007) and tablet method have been chosen. The tablet method has been used for different fireclay fillers with and without $\mathrm{K}_{2} \mathrm{CO}_{3}$ salt, as well as for quartz sand additive, thermal treatment, time and temperature differences. The method is designed to determine the mineralogical and chemical composition.

The methods applied for the establishment of the characteristics of the materials under the investigation included: chemical composition was identified upon applying 
the method of X-ray fluorescence spectroscopy with wave dispersion (XRF-WD) using spectrometer ZSX Primus IV (Rigaku Corp); for a qualitative phase analysis of materials, X-ray diffractometers "DRON-7" were used; the microstructure was examined by scanning electron microscopy device "JEOL JSM-7600F" with X-ray energy dispersion spectrometer (EDS) Inca Energy 350 (Oxford Instruments). The results of the XRD examinations have been processed with "Match!" program according to the Rietveld method.

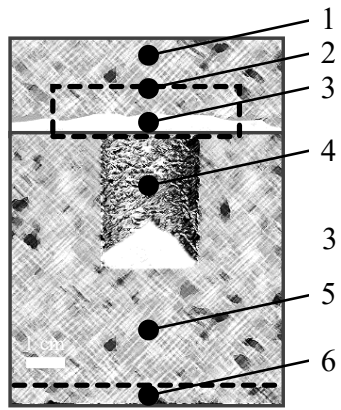

a)

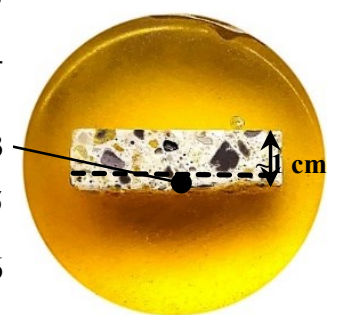

b)

Fig. S2.1. Crucible method scheme:

a) scheme of the sample; b) grind image for SEM - EDS studies

1 - castable plate; 2 - the sample used for the production of grind;

3 - a protective layer formed on the surface of the plate; 4 - cavity for $\mathrm{K}_{2} \mathrm{CO}_{3}$ salt; 5 - test sample;

6 - unaffected castable layer was used for XRD studies

To increase the alkali resistance of fireclay refractory concretes, the compositions of conventional and medium cement content with the addition of $2.5 \%$ ground quartz sand, which interacts with alkaline compounds and promotes the formation of a protective barrier, were selected (tables S2.1 and S2.2).

Table S2.1. Compositions of conventional castable (mass, \%)

\begin{tabular}{|c|c|c|c|c|c|c|}
\hline \multirow{2}{*}{ Components } & \multicolumn{7}{|c|}{ Castable composition mark } \\
\cline { 2 - 7 } & B2 & B3 & B4 & BQ2 & BQ3 & BQ4 \\
\hline CAC40 & 25 & 25 & 25 & 25 & 25 & 25 \\
\hline Microsilica & 2.5 & 2.5 & 2.5 & 2.5 & 2.5 & 2.5 \\
\hline Ground quartz sand & - & - & - & 2.5 & 2.5 & 2.5 \\
\hline Deflocculant FS 30* & 0.1 & 0.1 & 0.1 & 0.1 & 0.1 & 0.1 \\
\hline Ground fireclay: & & & & & & \\
BOS 125 & 12.5 & - & - & 10 & - & - \\
BOS 135 & - & 12.5 & - & - & 10 & - \\
BOS 145 & - & - & 12.5 & - & - & 10 \\
\hline Fireclay filler: & & & & & & \\
BOS 125 & 60 & - & - & 60 & - & - \\
BOS 135 & - & 60 & - & - & 60 & - \\
BOS 145 & - & - & 60 & - & - & 60 \\
\hline Water* & 10.4 & 10.4 & 8.5 & 10 & 10 & 8.5 \\
\hline
\end{tabular}

* - the content of the components exceeding $100 \%$ dry raw materials 
Table S2.2. Compositions of medium cement castable (mass, \%)

\begin{tabular}{|c|c|c|c|c|c|}
\hline \multirow{2}{*}{ Components } & \multicolumn{5}{|c|}{ Castable composition mark } \\
\cline { 2 - 6 } & VCB2 & VCB3 & VCB4 & VCB3-F & VCB4-F \\
\hline CAC70 & 12 & 12 & 12 & 12 & 12 \\
\hline Microsilica & 5 & 5 & 5 & 5 & 5 \\
\hline Reactive alumina & 5 & 5 & 5 & 5 & 5 \\
\hline Calcined alumina & 7 & 7 & 7 & 7 & 7 \\
\hline Ground quartz sand & 2.5 & 2.5 & 2.5 & 2.5 & 2.5 \\
\hline Deflocculant FS 20* & 0.1 & 0.1 & 0.1 & 0.1 & 0.1 \\
\hline Sodium tripolyphosphate* & 0.1 & 0.1 & 0.1 & 0.1 & 0.1 \\
\hline Ground fireclay: & & & & & \\
BOS 125 & 8 & - & - & - & - \\
BOS 135 & - & 8 & - & 8 & - \\
BOS 145 & - & - & 8 & - & 8 \\
\hline Fireclay filler: & & & & & \\
BOS 125 & 60.5 & - & - & - & - \\
BOS 135 & - & 60.5 & - & 60.5 & - \\
\hline BOS 145 & - & - & 60.5 & - & 60.5 \\
\hline Steel fibre* & - & - & - & 1 & 1 \\
\hline Water* & 9 & 9 & 8 & 9 & 8 \\
\hline
\end{tabular}

* - the content of the components exceeding $100 \%$ dry raw materials

It should also be noted that ultradisperse additives (microsilica, reactive alumina) were used in the castable compositions, which improve the structure of the matrix and the physical, mechanical and thermal properties of the castable. Three types of fireclay filer with different $\mathrm{Al}_{2} \mathrm{O}_{3} / \mathrm{SiO}_{2}$ ratio $(0,44 ; 0,68 ; 0,89)$ were used and this allows to reclassify the alkali resistance of fireclay refractory castable.

\section{Investigations of properties and alkali resistance of fireclay refractory castable}

XRD studies of a fireclay filler with an $\mathrm{Al}_{2} \mathrm{O}_{3} / \mathrm{SiO}_{2}$ ratio of $0.44 ; 0.68 ; 0.89$; and $\mathrm{K}_{2} \mathrm{CO}_{3}$ fired at 1100 and $1200{ }^{\circ} \mathrm{C}$ have shown that, regardless of the chemical composition of the fireclay, it is not resistant to alkali corrosion. After 5 hours of firing at $1100{ }^{\circ} \mathrm{C}$ and $1200{ }^{\circ} \mathrm{C}$, alkali corrosion products such as leucite and kalsilite are formed (Fig. S3.1). In reactions of the formation of corrosion products are involved in the formation mullite, quartz, tridymite and corundum of fireclay (the intensity of their peaks decreases).

Depending on the type of fireclay filler, corrosion products have different peak intensities: the higher the amount of alumina in the filler, (correspondingly lower levels of silicon dioxide) the higher the intensity of kalsilite and the lower the levels of leucite at $1100{ }^{\circ} \mathrm{C}$. Trends in corrosion products at $1200{ }^{\circ} \mathrm{C}$ vary, depending on the type of filler, with lower kalsilite intensity and higher leucite intensity. Prolonging the thermal treatment at $1100{ }^{\circ} \mathrm{C}$ or $1200{ }^{\circ} \mathrm{C}$ temperature for up to 15 hours reduces the amount of kalsilite (as this mineral is not stable) and results in higher levels of thermodynamically stable leucite. 


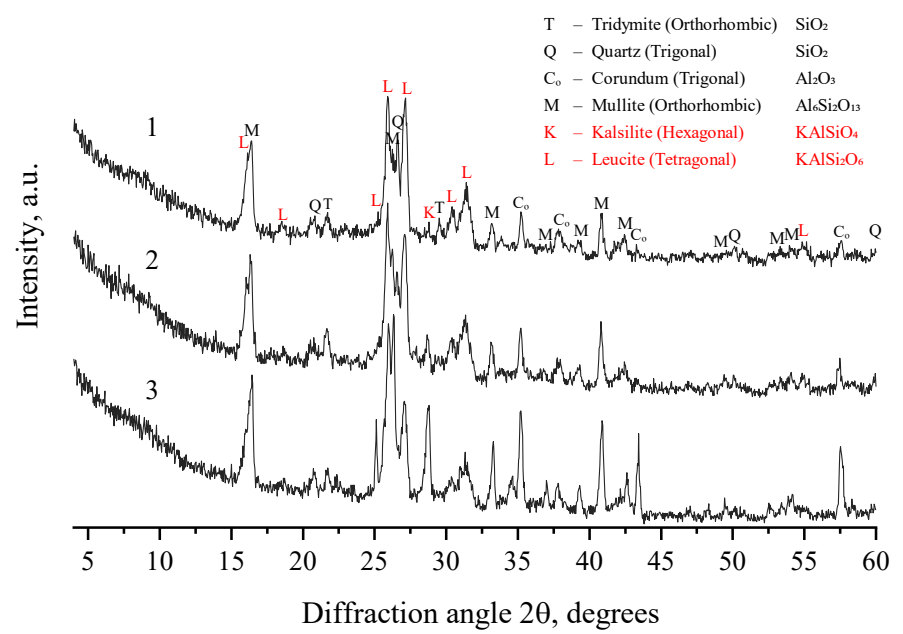

Fig. S3.1. X-ray pattern of fireclay aggregates treated with $\mathrm{K}_{2} \mathrm{CO}_{3}$ at $1100{ }^{\circ} \mathrm{C}$ for $5 \mathrm{~h}$ : 1 - BOS 125; 2 - BOS 135; 3 - BOS 145

The results show that in order to protect the aluminium silicate from alkali corrosion, the penetration of alkali compounds into its structure must be stopped or complicated.

Therefore, a quartz sand additive has been used to increase the alkali resistance of conventional and medium cement castable with fireclay filler to promote the formation of a barrier resistant to alkali corrosion by exposure to alkali melt.

The performance of the castable under investigation as set out in Tables S3.1 to S3.2 was initially determined.

Table S3.1. Characteristics of B and BQ series castable

\begin{tabular}{|c|c|c|c|c|c|c|}
\hline \multirow{2}{*}{ Properties } & \multicolumn{6}{|c|}{ Castable composition mark } \\
\hline & B2 & B3 & B4 & $\mathrm{BQ} 2$ & BQ3 & BQ4 \\
\hline $\begin{array}{l}\text { Density, } \mathrm{kg} / \mathrm{m}^{3} \text { : } \\
\text { after drying } 110^{\circ} \mathrm{C} \\
\text { after firing } 1100^{\circ} \mathrm{C}\end{array}$ & $\begin{array}{l}2080 \\
1960\end{array}$ & $\begin{array}{l}2080 \\
1960\end{array}$ & $\begin{array}{l}2260 \\
2140\end{array}$ & $\begin{array}{l}2090 \\
1970\end{array}$ & $\begin{array}{l}2100 \\
1990\end{array}$ & $\begin{array}{l}2240 \\
2120\end{array}$ \\
\hline $\begin{array}{l}\text { Compressive strength, MPa: } \\
\text { after drying } 110^{\circ} \mathrm{C} \\
\text { after firing } 1100^{\circ} \mathrm{C}\end{array}$ & $\begin{array}{l}71 \\
44\end{array}$ & $\begin{array}{l}71 \\
44\end{array}$ & $\begin{array}{c}109 \\
66\end{array}$ & $\begin{array}{l}73 \\
46\end{array}$ & $\begin{array}{l}76 \\
51\end{array}$ & $\begin{array}{c}105 \\
67\end{array}$ \\
\hline $\begin{array}{l}\text { Porosity, \%: } \\
\quad \text { after firing } 1100{ }^{\circ} \mathrm{C} \\
\text { after firing } 1200^{\circ} \mathrm{C} \\
\end{array}$ & $\begin{array}{c}26.2 \\
- \\
\end{array}$ & $\begin{array}{c}27.2 \\
- \\
\end{array}$ & $\begin{array}{c}23.0 \\
- \\
\end{array}$ & $\begin{array}{l}24.5 \\
26.4 \\
\end{array}$ & $\begin{array}{l}24.0 \\
25.3 \\
\end{array}$ & $\begin{array}{l}22.2 \\
23.1 \\
\end{array}$ \\
\hline Thermal shock resistance, in cycles & 9 & 11 & 20 & 8 & 10 & 17 \\
\hline Temperature of deformation, ${ }^{\circ} \mathrm{C}\left(\mathrm{T}_{5}\right)$ & - & - & - & 1270 & 1290 & 1300 \\
\hline
\end{tabular}

Using a higher $\mathrm{Al}_{2} \mathrm{O}_{3} / \mathrm{SiO}_{2}$ ratio $(0,89)$ fireclay filler, the performance of conventional and medium cement refractory castable (BQ4 and VCB4) at $1100{ }^{\circ} \mathrm{C}$ temperature was found to be better (with higher density, cold compression strength, 
thermal shock resistance, reduced porosity) compared to castable with a lower $\mathrm{Al}_{2} \mathrm{O}_{3} / \mathrm{SiO}_{2}$ ratio $(0,44$ and 0,68$)$. It was also found that the addition of $2,5 \%$ quartz sand, due to polymorphic changes at high temperatures, has no critical effect on the thermal shock resistance of castable. In the case of conventional castable (BQ series), the decrease in this parameter is up to $15 \%$ compared to the thermal shock resistance values of quartz sand-free castable (series B). As regards the change in ultrasonic pulse velocity in castable samples, the addition of $1 \%$ metal fibre, due to the reinforcement effect, has been shown to reduce the destruction of the medium cement castable (with an $\mathrm{Al}_{2} \mathrm{O}_{3} / \mathrm{SiO}_{2}$ ratio of 0,68 to 0,89 in the fireclay filler) by cyclically heating and cooling castable samples. This improves the thermal shock resistance of the castable.

Table S3.2. Characteristics of MCC series castable

\begin{tabular}{|c|c|c|c|}
\hline \multirow{2}{*}{ Properties } & \multicolumn{3}{|c|}{ Castable composition mark } \\
\cline { 2 - 4 } & VCB2 & VCB3 & VCB4 \\
\hline Density, $\mathrm{kg} / \mathrm{m}^{3}:$ & & & 2130 \\
after drying $110^{\circ} \mathrm{C}$ & 2130 & 2090 & 2250 \\
after firing $1100^{\circ} \mathrm{C}$ & 2080 & 2080 & 2200 \\
after firing $1200^{\circ} \mathrm{C}$ & 2080 & & \\
\hline Cold compressive strength, MPa: & & 55 & 109 \\
after drying $110^{\circ} \mathrm{C}$ & 47 & 76 & 126 \\
after firing $1100^{\circ} \mathrm{C}$ & 66 & 83 & 130 \\
after firing $1200^{\circ} \mathrm{C}$ & 78 & & \\
\hline Porosity, \%: & 20.9 & 20.3 & 20.1 \\
after firing $1100^{\circ} \mathrm{C}$ & 21.3 & & \\
after firing $1200^{\circ} \mathrm{C}$ & & 0.28 & 0.28 \\
\hline Shrinkage, \%: & 0.25 & 0.14 & 0.25 \\
after firing $1100^{\circ} \mathrm{C}$ & 0.11 & 24 & 29 \\
after firing $1200^{\circ} \mathrm{C}$ & 19 & 1400 & 1480 \\
\hline Thermal shock resistance, in cycles & 1390 & & \\
\hline Temperature of deformation, ${ }^{\circ} \mathrm{C}\left(\mathrm{T}_{5}\right)$ & & & \\
\hline
\end{tabular}

In the case of conventional castable alkali resistance, it was found that already after the first alkali resistance cycle in the B series of castable samples without quartz sand additive, cracks $>0,4 \mathrm{~mm}$ wide appeared (Fig. S3.2 a, b, c). The test reagent $\mathrm{K}_{2} \mathrm{CO}_{3}$ melts at $891{ }^{\circ} \mathrm{C}$ and absorbs easily into porous (open porosity $23,0-27,2 \%$, Table S3.1) the structure of this series of fireclay castable (penetrate into pores and capillaries causing cracks) (Fig. S3.2 d, e, f). Further cyclical exposure of the samples to $\mathrm{K}_{2} \mathrm{CO}_{3}$ progressively results in the development of cracks and, after 4 cycles, disintegration of the samples. 


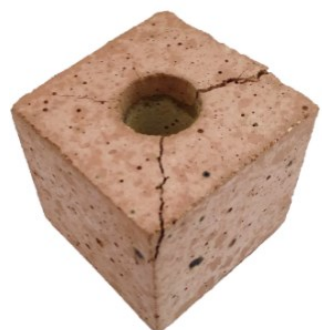

a)

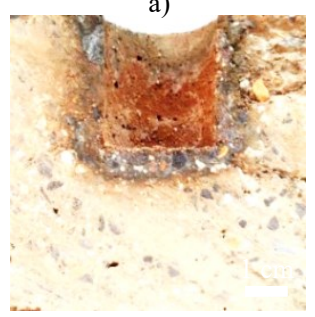

d)

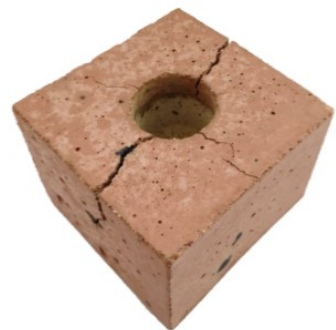

b)

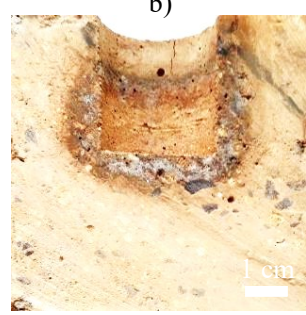

e)

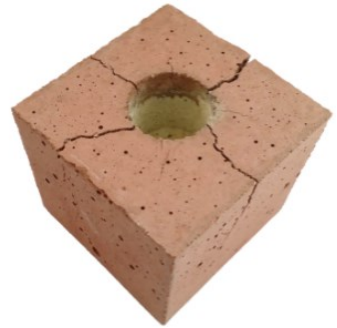

c)

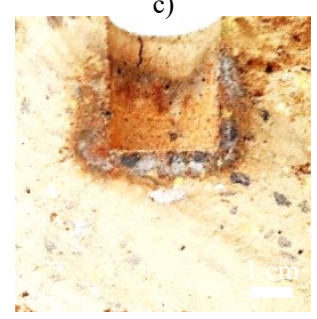

f)

Fig. S3.2. Samples view and of cross sections of B series castable samples after 1 cycle of alkali resistance test: $\mathrm{a}, \mathrm{d}-$ castable $\mathrm{B} 2$; b, e - B3; c, f - B4

As can be seen from Fig. S3.3, BQ series castable samples modified with a ground quartz sand additive show no visible defects after one test cycle. In the case of this castable, a layer of protective barrier is formed by contact of castable with potassium carbonate at high temperatures. In this case, the samples remain practically after 20 cycles.

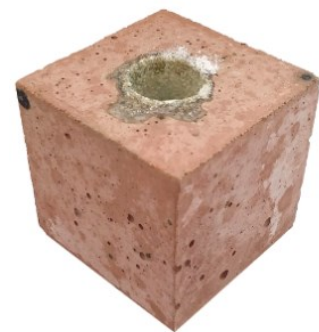

a)

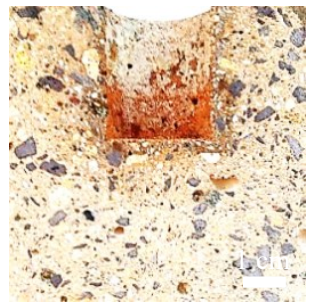

d)

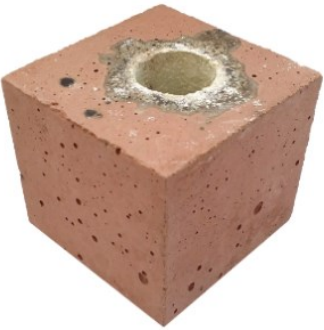

b)

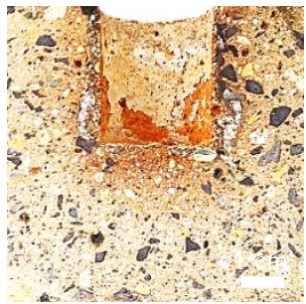

e)

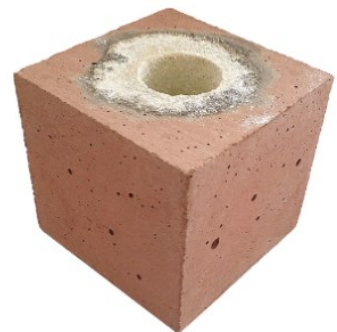

c)

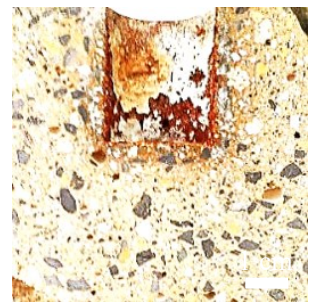

f)

Fig. S3.3. Samples view and of cross sections of $B Q$ series castable samples after 1 cycle of alkali resistance test: a, d-castable BQ2; b, e-BQ3; c, f-BQ4 
However, when the BQ series castable alkali resistance was tested at a temperature of $1200{ }^{\circ} \mathrm{C}$, all samples split, after the first cycle (Fig. S3.4 a, b, c). Two cycles later, the samples completely disintegrated into pieces. This means that at $1200{ }^{\circ} \mathrm{C}$ no protective barrier is formed in conventional castable with quartz sand additive. The penetration of alkali melt into the material can be explained by changes in the porosity parameters of the castable. It is established (Table S3.1) that open porosity increases to $\sim 23-26 \%$ by raising the firing temperature from $1100{ }^{\circ} \mathrm{C}$ to $1200^{\circ} \mathrm{C}$.

As wood fuels burn, the maximum operating temperature of the boiler usually does not exceed $1100{ }^{\circ} \mathrm{C}$. Therefore, modified conventional castable with ground quartz sand additive can be used for the installation of boiler lining. However, they may not be used in areas where secondary air is supplied and where local temperatures reach $1200{ }^{\circ} \mathrm{C}$ and an alkali corrosion may occur.

The results of an alkali resistance test of the medium cement castable with quartz sand additive indicate that protective barrier layer forms at the surface of the samples above $1100{ }^{\circ} \mathrm{C}$ at $1200{ }^{\circ} \mathrm{C}$. From the following sections (Fig. S3.4 d, e, f) we can find that there are no visually observable signs of degradation of the VCB series castable microstructure at $1200{ }^{\circ} \mathrm{C}$ after 6 cycles. The open porosity of the medium cement castable is about $\sim 21 \%$ at $1200{ }^{\circ} \mathrm{C}$. Visibly, with this porosity of the material, the protective barrier formed is stable at $1200{ }^{\circ} \mathrm{C}$.

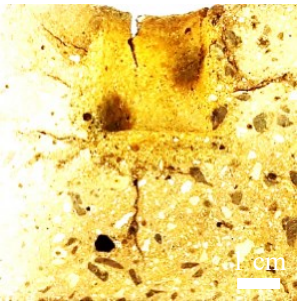

a)

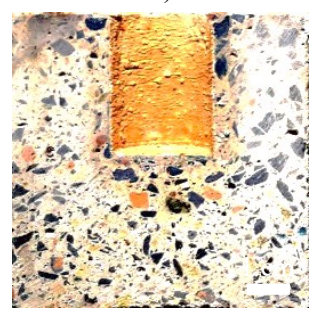

d)

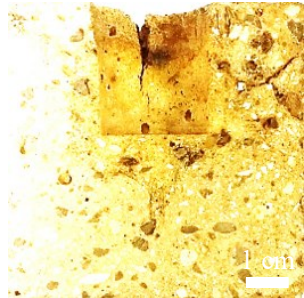

b)

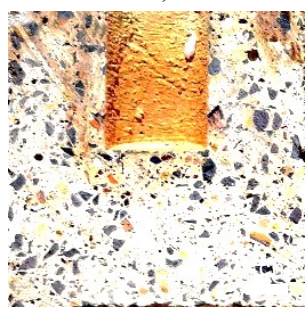

e)

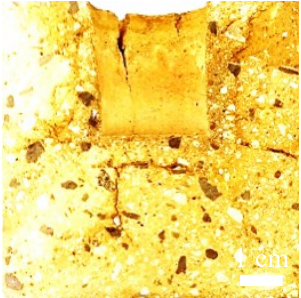

c)

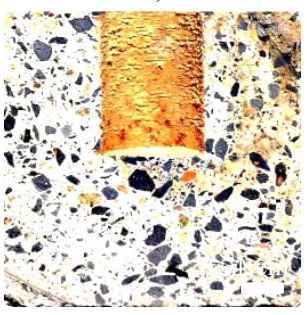

f)

Fig. S3.4. Cross section view of BQ (a, b, c) and VCB series ( $d, e, f)$ castable samples after 1 cycle of BQ and after 6 cycle of VCB alkali resistance test at $1200^{\circ} \mathrm{C}$ temperature: a - castable BQ2; b - BQ3; c - BQ4; d-VCB2; e - VCB3; f-VCB4

Further investigation with BQ3, BQ4, VCB3, VCB4 castable have been carried out due to their maximum thermal shock resistance. This does not apply to castable with BOS 125 fireclay filler (BQ2 and VCB2 castable). Based on the results of the study of the surface layer of castable samples in which the protective barrier was formed, the quartz sand additive was found to influence the formation of a protective barrier in the fireclay castable by promoting the formation of an amorphous phase (glass). In addition to glass 
melt, growing crystalline corrosion products such as kalsilite, leucite, potassium silicate, and wadeite (Fig. S3.5) close pores and capillaries dominating in castable. Obviously, this is how the protective barrier area is formed.

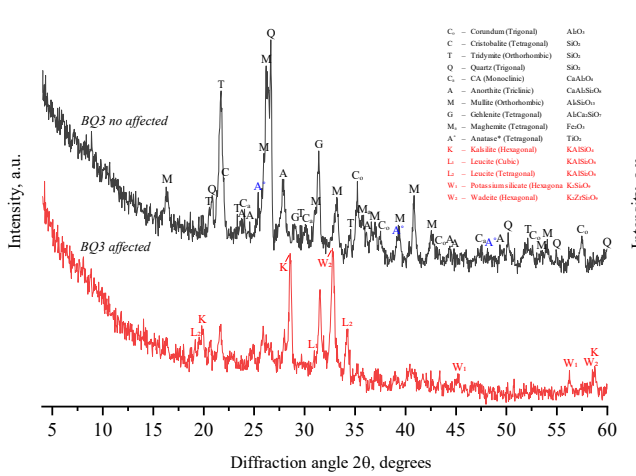

a)

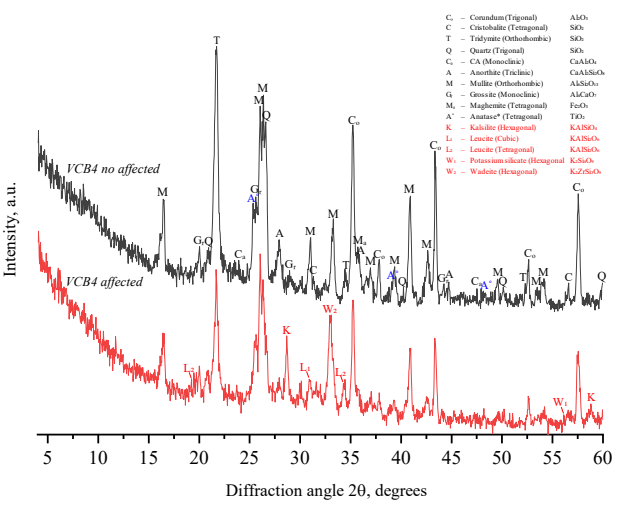

b)

Fig. S3.5. X-ray diffraction patterns with characteristic mineral marks of control BQ3 (a) and VCB4 castable (b) after firing at $1100{ }^{\circ} \mathrm{C}$ and surface layer of analogous castable sample after 3 cycles of alkali resistance under $\mathrm{K}_{2} \mathrm{CO}_{3}$

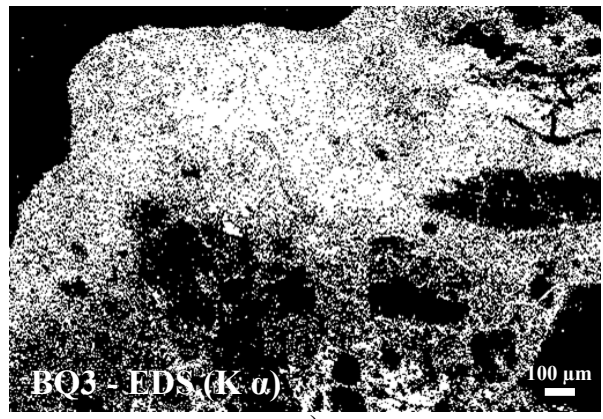

a)

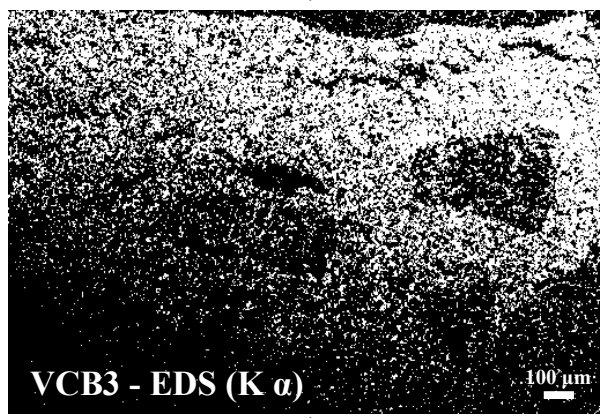

c)

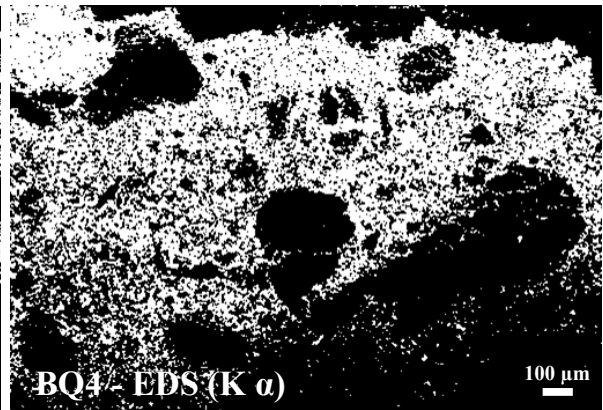

b)

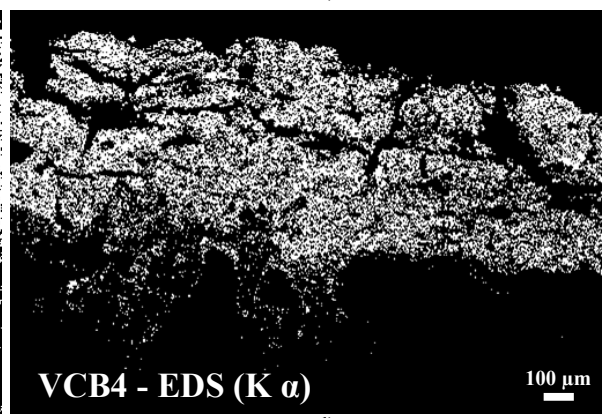

d)

Fig. S3.6. Potassium distribution of various castables in EDS maps after 3 cycles of alkali resistance with $\mathrm{K}_{2} \mathrm{CO}_{3}$ at $1100{ }^{\circ} \mathrm{C}$ : a) BQ3 castable surface;

b) BQ4 castable surface; c) VCB3 castable surface; d) VCB4 castable surface 
The mineral composition of the protective barrier (Table S3.3) depends on the type of castable - corrosion products produced in the crystalline phase were found to be the highest in the BQ series ( 43\%), the lowest in the VCB series of castable (VCB3 - 33.8\%, VCB4 - 19.7\%).

Figure S3.6 shows the visual distribution of potassium from EDS studies (analysis of a layer of material of $\sim 1500 \mu \mathrm{m}$ thickness) for all tested castable after 3 alkali resistance cycles at $1100{ }^{\circ} \mathrm{C}$. As we can see, the concentration of potassium in the surface sample layer where the protective barrier was formed is quite high. Potassium concentrations are clearly reduced in the zone below the barrier (hereinafter referred to as the remaining area).

The barrier is discreet and as the number of alkali cycles increases not only does its thickness increase, but also $\mathrm{K}$ penetration into the material structure takes place (Table $\mathrm{S} 3.4)$. The thickness of the barrier and $\mathrm{K}$ penetration potential are influenced by the characteristics of the refractory castable microstructure. The minimum $\mathrm{K}$ penetration into the material structure is determined by VCB4 castable, which has the most dense structure, minimum porosity and maximum thermal shock resistance (minimum destruction in thermal shocks). As mentioned above (crucible results), no critical effect of potassium penetration through the barrier has been observed on the condition of all castable samples over 20 cycles of alkali resistance. However, the identified barrier formation characteristics (Table S3.3, S3.4) allow to predict that of all the castable studied, VCB4 is the most resistant to alkali corrosion.

Table S3.3. Summary of X-ray examination results of the affected castable after 3 cycles of alkali resistance at $1100{ }^{\circ} \mathrm{C}$ by "Match!" program according to the Rietveld method

\begin{tabular}{|c|c|c|c|c|c|c|}
\hline \multirow{2}{*}{ Type } & \multirow{2}{*}{$\begin{array}{c}\text { Mineral } \\
\text { (crystallographic system) }\end{array}$} & \multirow{2}{*}{ Formula } & \multicolumn{4}{|c|}{ Castable } \\
\hline & & & BQ3 & BQ4 & VCB3 & VCB4 \\
\hline \multirow{10}{*}{ 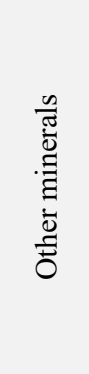 } & Corundum (Trigonal) & $\mathrm{Al}_{2} \mathrm{O}_{3}$ & 4.0 & 6.4 & 9.7 & 13.9 \\
\hline & Cristobalite (Tetragonal) & $\mathrm{SiO}_{2}$ & 1.9 & 1.8 & 2.5 & 3.1 \\
\hline & Tridymite (Orthorhombic) & $\mathrm{SiO}_{2}$ & 3.7 & 3.1 & 4.2 & 3.0 \\
\hline & Quartz (Trigonal) & $\mathrm{SiO}_{2}$ & 2.2 & 1.3 & 4.3 & 3.6 \\
\hline & CA (Monoclinic) & $\mathrm{CaAl}_{2} \mathrm{O}_{4}$ & 4.9 & 4.9 & 4.8 & 4.7 \\
\hline & Anorthite (Triclinic) & $\mathrm{CaAl}_{2} \mathrm{Si}_{2} \mathrm{O}_{8}$ & 17.4 & 10.6 & 10.1 & 7.5 \\
\hline & Mullite (Orthorhombic) & $\mathrm{Al}_{6} \mathrm{Si}_{2} \mathrm{O}_{13}$ & 14.2 & 19.6 & 17.8 & 33.0 \\
\hline & Gehlenite (Tetragonal) & $\mathrm{Al}_{2} \mathrm{Ca}_{2} \mathrm{SiO}_{7}$ & 8.0 & 7.6 & - & - \\
\hline & Grossite (Monoclinic) & $\mathrm{Al}_{4} \mathrm{CaO}_{7}$ & - & - & 10.3 & 9.1 \\
\hline & Maghemite (Tetragonal) & $\mathrm{Fe}_{2} \mathrm{O}_{3}$ & 0.9 & 1.0 & 2.5 & 2.4 \\
\hline \multirow{5}{*}{ 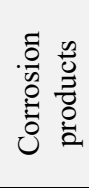 } & Kalsilite (Hexagonal) & $\mathrm{KAlSiO}_{4}$ & 10.6 & 7.3 & 7.7 & 4.3 \\
\hline & Leucite (Cubic) & $\mathrm{KAlSi}_{2} \mathrm{O}_{6}$ & 1.0 & 1.0 & 1.5 & 2.2 \\
\hline & Leucite (Tetragonal) & $\mathrm{KAlSi}_{2} \mathrm{O}_{6}$ & 7.7 & 7.4 & 5.7 & 5.6 \\
\hline & Potassium silicate (Hexagonal) & $\mathrm{K}_{2} \mathrm{Si}_{4} \mathrm{O}_{9}$ & 19.8 & 24.6 & 17.2 & 5.7 \\
\hline & Wadeite (Hexagonal) & $\mathrm{K}_{2} \mathrm{ZrSi}_{3} \mathrm{O}_{9}$ & 3.7 & 3.4 & 1.7 & 1.9 \\
\hline \multicolumn{3}{|c|}{ Sum of castable corrosion products, $\%$} & 42.8 & 43.7 & 33.8 & 19.7 \\
\hline \multicolumn{3}{|c|}{ Sum of all minerals, $\%$} & 100.0 & 100.0 & 100.0 & 100.0 \\
\hline \multicolumn{3}{|c|}{ CRYSTALLINE PHASE, \% } & 63.5 & 64.2 & 64.6 & 65.4 \\
\hline \multicolumn{3}{|c|}{ AMORPHIC PHASE (glass), $\%$} & 36.5 & 35.8 & 35.4 & 34.6 \\
\hline \multicolumn{3}{|c|}{ Sum of both phases, $\%$} & 100.0 & 100.0 & 100.0 & 100.0 \\
\hline
\end{tabular}


Table S3.4. Percentage averages of the main chemical elements in two zones of different castable (barrier and remaining area) after 3 and 6 cycles of alkali resistance under $\mathrm{K}_{2} \mathrm{CO}_{3}$ at $1100{ }^{\circ} \mathrm{C}$

\begin{tabular}{|c|c|c|c|c|c|c|c|c|}
\hline \multirow[t]{2}{*}{ Castable } & \multirow{2}{*}{$\begin{array}{l}\text { Number } \\
\text { of cycles }\end{array}$} & \multirow[t]{2}{*}{ Characteristics fo zone } & \multicolumn{5}{|c|}{$\begin{array}{c}\text { Average of chemical } \\
\text { elements, } \%\end{array}$} & \multirow{2}{*}{$\begin{array}{c}\text { Amount } \\
\%\end{array}$} \\
\hline & & & $\mathrm{K}$ & $\mathrm{Al}$ & $\mathrm{Si}$ & $\mathrm{Ca}$ & $\mathrm{O}$ & \\
\hline \multirow{4}{*}{ BQ3 } & \multirow{2}{*}{3} & Barrier zone; $\sim 1300 \mu \mathrm{m}$ & 25.9 & 9.0 & 10.0 & 5.8 & 49.3 & 100.0 \\
\hline & & Remaining area & 16.9 & 12.2 & 12.9 & 6.9 & 51.1 & 100.0 \\
\hline & \multirow{2}{*}{6} & Barrier zone; $\sim 2400 \mu \mathrm{m}$ & 39.2 & 8.0 & 3.1 & 1.3 & 48.4 & 100.0 \\
\hline & & Remaining area & 28.9 & 9.9 & 9.5 & 4.6 & 47.1 & 100.0 \\
\hline \multirow{4}{*}{ BQ4 } & \multirow{2}{*}{3} & Barrier zone; $\sim 1100 \mu \mathrm{m}$ & 22.6 & 16.7 & 11.2 & 1.8 & 47.7 & 100.0 \\
\hline & & Remaining area & 16.7 & 15.7 & 14.2 & 5.2 & 48.2 & 100.0 \\
\hline & \multirow{2}{*}{6} & Barrier zone; $\sim 1250 \mu \mathrm{m}$ & 37.1 & 4.1 & 5.0 & 1.6 & 52.2 & 100.0 \\
\hline & & Remaining area & 19.9 & 17.6 & 13.1 & 4.1 & 45.3 & 100.0 \\
\hline \multirow{4}{*}{ VCB3 } & \multirow{2}{*}{3} & Barrier zone; $\sim 1200 \mu \mathrm{m}$ & 25.7 & 12.3 & 11.8 & 1.5 & 48.7 & 100.0 \\
\hline & & Remaining area & 10.2 & 14.2 & 17.4 & 2.0 & 56.2 & 100.0 \\
\hline & \multirow{2}{*}{6} & Barrier zone; $\sim 1500 \mu \mathrm{m}$ & 24.3 & 13.7 & 9.2 & 1.7 & 51.1 & 100.0 \\
\hline & & Remaining area & 16.9 & 15.2 & 15.1 & 2.4 & 50.4 & 100.0 \\
\hline \multirow{4}{*}{ VCB4 } & \multirow{2}{*}{3} & Barrier zone; $\sim 700 \mu \mathrm{m}$ & 24.4 & 16.0 & 11.9 & 1.3 & 46.4 & 100.0 \\
\hline & & Remaining area & 5.8 & 23.9 & 18.8 & 6.8 & 44.7 & 100.0 \\
\hline & \multirow[b]{2}{*}{6} & Barrier zone; $\sim 1500 \mu \mathrm{m}$ & 23.4 & 13.1 & 11.4 & 2.8 & 49.3 & 100.0 \\
\hline & & Remaining area & 13.2 & 19.3 & 14.1 & 5.0 & 48.4 & 100.0 \\
\hline
\end{tabular}

It should also be noted that potassium penetration is observed in the castable matrix and its diffusion to fillers after 6 alkaline cycles is minimal. This indicates that future studies should be envisaged to increase the resistance of the matrix to alkaline penetration.

\section{General conclusions}

1. The studies of mixes of fireclay fillers with $\mathrm{K}_{2} \mathrm{CO}_{3}$ have shown that fillers of this type are not resistant to alkali corrosion after heating at $1100{ }^{\circ} \mathrm{C}$ and $1200{ }^{\circ} \mathrm{C}$, regardless of what the real ratio of $\mathrm{Al}_{2} \mathrm{O}_{3} / \mathrm{SiO}_{2}(0,44 ; 0,68 ; 0,89)$ is in the fireclay filler.

2. With a higher $\mathrm{Al}_{2} \mathrm{O}_{3} / \mathrm{SiO}_{2}$ ratio (0.89) fireclay filler, it was found that the performance of conventional and medium cement refractory castable at $1100{ }^{\circ} \mathrm{C}$ is better compared to castable with a lower $\mathrm{Al}_{2} \mathrm{O}_{3} / \mathrm{SiO}_{2}$ ratio (0.68 and 0.44). Castables with such filler are characterized by lower open porosity, higher density, compressive strength and thermal shock resistance.

3. It has been established that the addition of quartz sand ground at a temperature of $1100{ }^{\circ} \mathrm{C}$ influences the formation of protective barrier on the surface of castable specimens, regardless of the type of castable and fireclay filler. As a result, the alkali resistance of conventional and medium cement refractory castable reaches not less than 20 cycles.

4. It has been established that after 3 alkali cycles, the amount of amorphous phase in the protective barrier increases compared to unaffected castable. The products 
of alkali corrosion in the crystalline state have been identified: kalsilite, cubic leucite, tetragonal leucite, potassium silicate and wadeite. Potentially crystalline and amorphous reaction products fill the pores and capillaries of the material, together forming a protective layer and making it more difficult for potassium to penetrate into the deeper layers of the material.

5. The peculiarities of protective barrier formation in fireclay castable with cyclic operation of $\mathrm{K}_{2} \mathrm{CO}_{3}$ and high temperatures have been identified: in the barrier zone, potassium penetrates increasingly deeply with each cycle; the barrier zone consists of the crystalline phase and the amorphic phase (glass phase); potassium compounds (corrosion products) increase with each cycle. In case of more alkali resistant castable, the amount of amorphic phases decreases and crystalline corrosion products increase in the case of less alkali resistant castable. These are the basic criteria for forecasting corrosion intensity (both absolute \% and variance in content with cycles). All of this also allows to evaluate the stability of barrier at $1100{ }^{\circ} \mathrm{C}$ during alkali corrosion cycles.

6. It has been assessed that protective barrier in conventional castable with quartz sand additives is not stable at $1200^{\circ} \mathrm{C}$. In medium cement castable protective barrier is formed and is stable both at 1100 and $1200{ }^{\circ} \mathrm{C}$. Penetration of alkalis into material can be explained by changes in porosity parameters of castable. Open porosity of conventional castable increases from $\sim(22-24) \%$ to $\sim(23-26) \%$ when raising the heating temperature from $1100{ }^{\circ} \mathrm{C}$ to $1200^{\circ} \mathrm{C}$. Open porosity of medium cement castable is lower at $1200{ }^{\circ} \mathrm{C}$ and reaches $\sim 21 \%$. 



\section{Priedai $^{1}$}

A priedas. Kontrolinio $B Q 4$ ir VCB3 betonu po degimo $1100{ }^{\circ} \mathrm{C}$ temperatūroje ir analogiško betono bandinių paviršiaus sluoksnio po 3 šarminio atsparumo ciklu veikiant $\mathrm{K}_{2} \mathrm{CO}_{3}$, rentgenogramos

B priedas. Autoriaus sąžiningumo deklaracija

C priedas. Bendraautorių sutikimai teikti publikacijose skelbtą medžiagą daktaro disertacijoje

D priedas. Autoriaus mokslinių publikacijų disertacijos tema kopijos

${ }^{1}$ Priedai pateikiami pridètoje kompaktinejje plokštelëje. 
Povilas ZDANEVIČIUS

ŠAMOTINIO UGNIAI ATSPARAUS BETONO

ŠARMINIO ATSPARUMO TYRIMAI

Daktaro disertacija

Technologijos mokslai, medžiagų inžinerija (T 008)

THE INVESTIGATION OF ALKALI RESISTANCE OF FIRECLAY REFRACTORY CASTABLE

Doctoral Dissertation

Technological Sciences,

Materials Engineering ( $\mathrm{T}$ 008)

202105 07. 10,0 sp. I. Tiražas 20 egz.

Leidinio el. versija https://doi.org/10.20334/2021-024-M

Vilniaus Gedimino technikos universitetas

Saulètekio al. 11, 10223 Vilnius

Spausdino Bl UAB „Baltijos kopija“

Kareivių g. 13B, 09109 Vilnius 